\title{
THE UNITED STATES
}

GEOLOGICAL SURVEY IN ALASKA Accomplishments During 1983

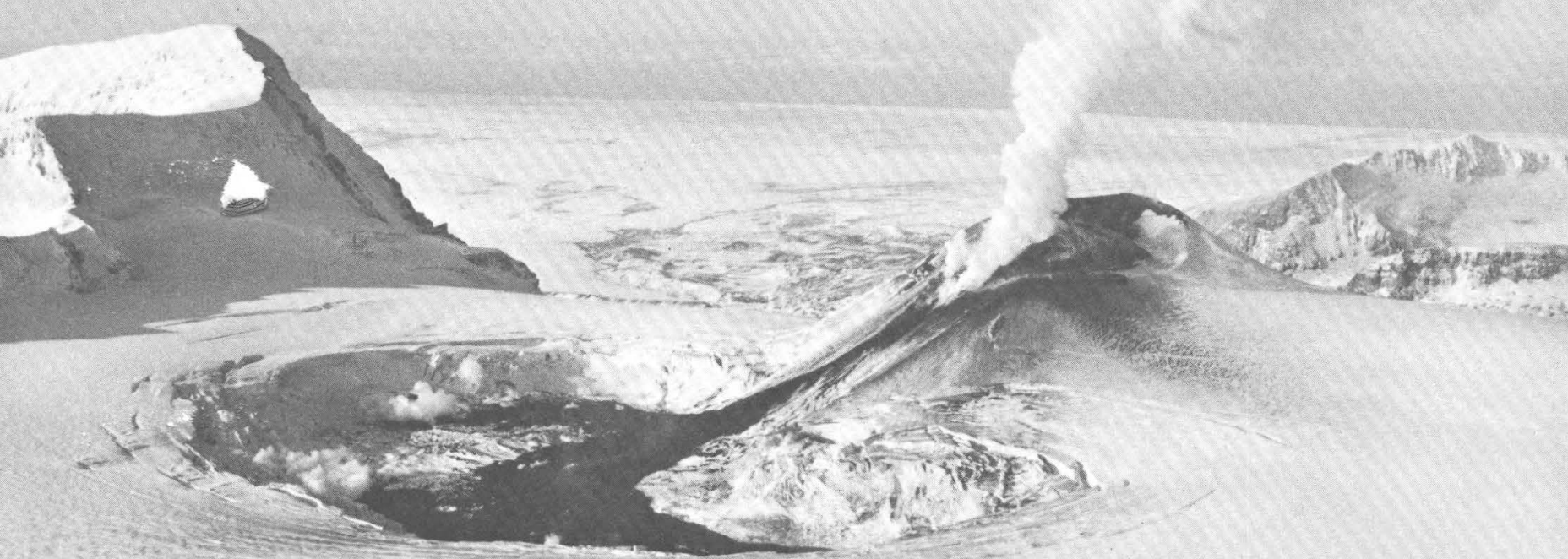




\section{Front Cover}

Eruption of Mt. Veniaminof, Alaska Peninsula, January 23, 1984. In the background are the Bristol Bay Lowlands and Bristol Bay.

\section{Back Cover}

The photographs on the back cover are of the eruption of Mt. Veniaminof that lasted from June 1983 to April 1984. The eruption was from the crater of an exisiting cinder cone in Veniaminof Caldera. The cone is surrounded by glacial ice, which fills the caldera.

Top left.--During the first few days of the eruption, a circular depression formed in the glacial ice south of the cinder cone. Between the depression and the cone, a 90-m-wide sector graben formed in the cone's wall. The crater, which prior to the eruption was $300 \mathrm{~m}$ deep, gradually filled with ejecta and magma. This view, from the south-southeast on June 7, 1983, shows both the circular depression and the sector graben. Arcuate cracks around the depression are well defined by the contrast between the ashcovered ice and the clean vertical walls.

Top right.--By June 9, 1983, when this photograph was taken, the crater had overflowed. A lava flow down the southwest side of the cinder cone melted a small pit in the glacial ice (site of the steam in this photograph). A small amount of meltwater formed a lake on the ice surface between the circular depression (right) and the pit.

Center left.--This view from the west-northwest on July 13, 1983, shows the pit, now enlarged and bilobate, and the meltwater lake. In this photograph, the eastern lobe is the site of the former circular depression; the western lobe, in the foreground, is the locus of an expanding lava delta. Ice walls were estimated to be $60-100 \mathrm{~m}$ high; depth of the lake was unknown. Beyond the ice-draped south rim of the crater, clouds cover lower peaks.

Center right.--This ice-choked subglacial tunnel was observed on July 13, 1983 , in the ice wall of the eastern end of the lake. It is thought to be the path of eastward subglacial drainage from the lake.

Bottom.-By November 4, 1983, lava flows completely covered the floor of the western lobe of the pit. The dark area is the active lava flow; a dusting of snow covers earlier flows. The lake was reduced to a small pond not visible in this view. This is the same perspective as the center left photograph, above.

An article by Yount, Miller, Emanuel, and Wilson (this volume) describes the eruption. 


\title{
THE
}

\section{UNITED STATES GEOLOGICAL SURVEY}

\author{
IN ALASKA:
}

ACCOMPLISHMENTS DURING 1983

Susan Bartsch-Winkler and Katherine M. Reed, Editors

U.S. GEOLOGICAL SURVEY CIRCULAR 945

Short papers

describing results of

recent geologic investigations 


\section{DEPARTMENT OF THE INTERIOR DONALD PAUL HODEL, Secretary \\ U.S. GEOLOGICAL SURVEY \\ Dallas L. Peck, Director}

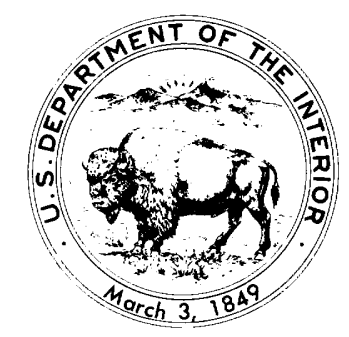

Library of Congress Catalog Card Number 76-608093

Free on application to Distribution Branch, Text Products Section, U.S. Geological Survey, 604 South Pickett Street, Alexandria, VA 22304 


\section{CONTENTS}

Page

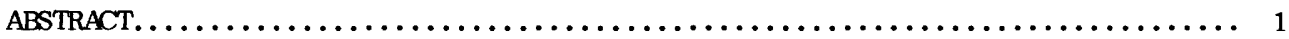

INTRODUCTION $\ldots \ldots \ldots \ldots \ldots \ldots \ldots \ldots \ldots \ldots \ldots \ldots \ldots \ldots \ldots \ldots \ldots \ldots \ldots \ldots \ldots \ldots$

STATEWIDE

Evidence that gold crystals can nucleate on bacterial spores, by John R. Watterson, James M. Nishi, and Theodore Botinelly........ 1

Trace elements of placer gold,

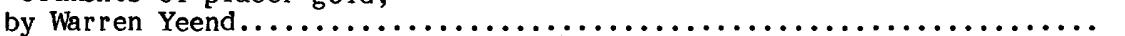

\section{NORTHERN ALASKA}

Buried felsic plutons in Upper Devonian redbeds, central Brooks Range, by Donald J. Grybeck, John B. Cathrall,

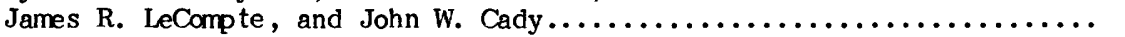

New reference section of the Noatak Sandstone, Nimiuktuk River, Mi sheguk Mounta in Quadrangle, central Brooks Range, by Tor H. Nilsen, William P. Brosge, and J. Thomas Dutro, Jr....... 10

\section{WEST-CENTRAL ALASKA}

New radiometric evidence for the age and thermal history of the metamorphic rocks of the Ruby and Nixon Fork terranes, by John T. Dillon, Wi 11 i am W. Patton, Jr., Samuel B. Mukasa, George R. Tilton, Joel Blum, and Elizabeth J. Mbll.................

Seacliff exposures of metamorphosed carbonate and schist, northern

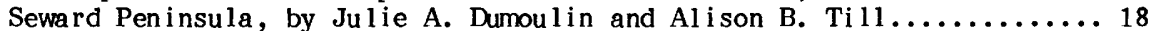

Windy Creek and Crater Creek faults, Seward Peninsula,

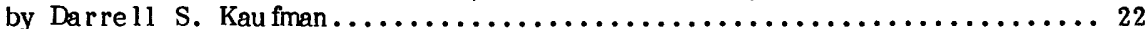

Metamorphic rocks in the western Iditarod Quadrangle, by Marti L. Miller and Thomas K. Bundtzen................... 24

\section{EAST-CENTRAL ALASKA}

Studies of gold in the Chandalar and Koyukuk Districts, Wiseman and Bettles Quadrangles-A progress report, by John C. Antwe iler, Richard B. Tripp, John B. Cathra 11,

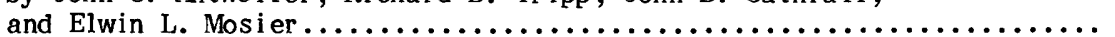

New concepts of the Mesozoic flysch belt in east-central Alaska, by Robert M. Chapman, James H. Trexler, Jr., Mi chae 1 Churkin, Jr., and Florence R. Weber.................. 29

Major rock packages of the Ray Mountains, Tanana and Bettles Quadrangles,

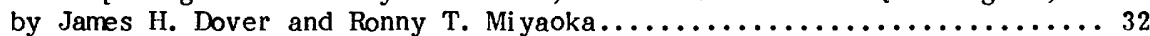

Me tamorphic rocks of the Ray Mountains--Preliminary structural analys is and regional tectonic implications, by James H. Dover and R. T. Miyaoka............................ 36

Tertiary(?) folding in the Tanacross Quadrangle, by Hel en L. Foster and Grant W. Cushing $\ldots \ldots \ldots \ldots \ldots \ldots \ldots \ldots \ldots \ldots$

Statistical discrimination between potential tin- and uranium-bearing areas in east-central Alaska on the basis of stream-sediment trace-element geochemistry, by Ga il M. Jones, W. David Menzie, and Helen L. Foster............440

Peridotite-layered gabbro complex of the southeastern Yuk on-Koyukuk ophiol ite belt by Robert A. Loney and Glen R. Himmelberg.................. 46 


\section{SOUTHWESTERN ALASKA}

Kaguyak Formation--An Upper Cretaceous flysch deposit, by Robert L. Detterman and John W. Mi ller................... 49

The Buchia zones in Upper Jurassic rocks on the Alaska Pen insula, by John W. Mi ller and Robert L. Detterman ................... 51

Jurassic Radiolaria from the Lime Hills Quadrangle, by Kather ine M. Reed, Charles D. Blome, Wyatt G. Gi lbert,

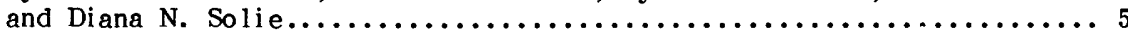

Preliminary description of a Mi ocene zone of structural complexity in the Port Moller and Stepovak Bay Quadrangles, by Frederic H. Wil son, James E. Case, and Robert L. Detterman........ 55

Digital image processing techniques for detecting surface alteration-An application on the Alaska Peninsula, by James E. York, Frederic H. Wi lson, and Bruce M. Gamble......... 56

Eruption in the ice-filled caldera of Mount Veniaminof, by M. El i zabeth Yount, Thomas P. Miller, Richard P. Emanuel, and Frederic H. Wilson............................... 59

Newly discovered Holocene volcanic vents, Port Moller and Stepovak Bay Quadrangles, by M. El izabeth Yount, Freder ic H. Wilson, and John W. Miller........6 60

\section{SQUTHERN ALASKA}

Age of intrusion and metamorphism of a granodiorite in the Lake George terrane, northeastern Mount Hayes Quadrangle,

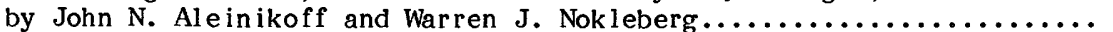

Geophysical data emphasize importance of the Talkeetna fault system relative to the Denali system,

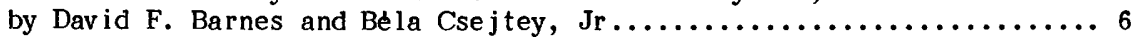

Magnetic profile across the Denali Fault, Mount Hayes Quadrangle, Eastern Alaska Range, by David L. Campbell and Warren J. Nokleberg................. 6

Lead isotopes in sulfide deposits from the Jarvis Creek Glacier and Wrangell ia terranes, Mount Hayes Quadrangle, eastern Alaska Range, by Anne P. LeHuray, Stanley E. Church, and Warren J. Nokleberg....... 72

Petrography of sandstone from the Yakutat Group, Malaspina district, southern Alaska, by John S. Lull and George Plafker...

Volcanogen ic massive sulfide occurrences, Jarvis Creek Glacier terrane, western Mount Hayes Quadrangle, eastern Alaska Range, by Warren J. Nokleberg and I an M. Lange......

The Columbia Bay earthquakes of 1983 , southern Alaska, by Robert Page, Chr is topher D. Stephens, Kent A. Fog leman, and Richard P. Maley ........

Kayak Is land--Ana lys is of a geochemi cal anomaly, by Wi 11 iam J. Pick thorn, Richard J. Goldfarb, Ri chard M. O'Leary, Stephen J. Sutley, and Sarah Weaver...

Se ismicity in southern Alaska, October 1982-September 1983, by Chr istopher D. Stephens, Kent A. Fogleman, Robert A. Page, and John C. Lahr. 
CONTENTS-continued

\section{SOUTHFASTERN ALASKA}

Re-interpretation of age of Kuiu-Etolin belt volcanic rocks, Kupreanof Island, southeastern Alaska, by David A. Brew, Susan M. Kar 1 , and Eugene F. Tobey............86

Biogeochemical response at the Greens Creek massive sulfide deposit, Admiralty Is land, by James A. Erdman and Jerry M. Motooka $\ldots \ldots \ldots \ldots \ldots \ldots \ldots \ldots \ldots$

Chemical zonation of garnet in pelitic rocks of the Coast plutonic-metamorph ic complex near Juneau, by Glen R. Himme lberg, Arthur B. Ford, David A. Brew, and Stephen Van Horn ..................................... 9

Relations between the tidal-flat environment and upstream mineralization, Petersburg Quadrangle by Lorra ine H. Filipek, Theodore Bot inelly, and Walter H. Ficklin.....92

Lead isotopes from volcangenic massive sulfide deposits from the Al exander terrane, southeastern Alaska, by Anne P. LeHuray, Harold S. Stowe 11, and Stanley E. Church.........95

Sphalerite geobarometry in the Coast Range megalineament zone near Holkham Bay, southeas tern Alaska,

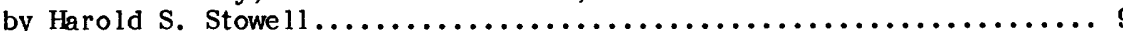

OFFSHORE

Character and implications of new ice gouges in eastern Harr ison Bay, Beaufort Sea,

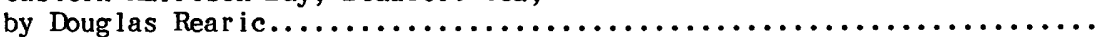

Late Quaternary geology of the Beaufort Sea inner shelf near Prudhoe Bay,

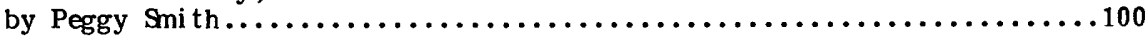

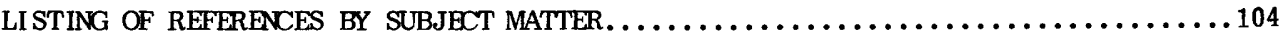

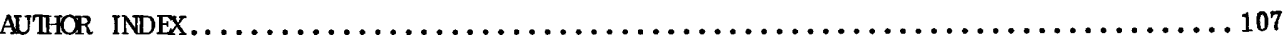

\section{ILLUSTRATIONS}

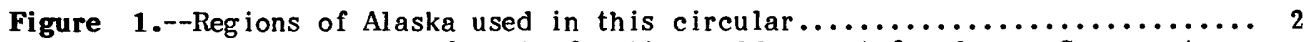
2.--SEM photograph of part of a tiny gold nugget found near Sacramento,

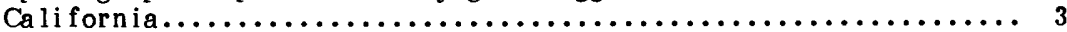

3.--X-ray diffraction patterns of $B$. cereus spores after overnight exposure to $1000 \mathrm{mi}$ crogram/ml aqueous gold chlor ide solution and a gold standard from $\mathrm{Cr}$ ipple Creek, Colorado.............. 4

4.--SEM photographs of resultant gold-coated B. cereus spores after 36 -hour exposure to $1000 \mathrm{mi} \mathrm{crogram} / \mathrm{ml}$ aqueous gold chlor ide..... 5

5.--Map showing areas in northern Alaska discussed in this circular..... 8 6.--Map showing location of suspected buried felsic plutons in Survey Pass Quadrangle, Brooks Range..................... 9

7.--Geologic map showing location of measured sections of the Noatak

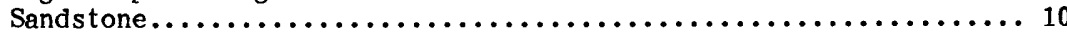

8.--New reference section of Noatak Sandstone measured in $1983 \ldots \ldots \ldots \ldots 11$

9.--Map showing areas in west-central Alaska discussed in this

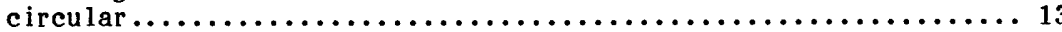




\section{LIST OF ILLUSTRATIONS-continued}

10.--Sketch map of the geology of the Yukon-upper Kuskokwim Rivers

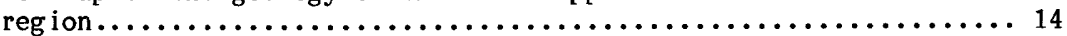

11.--Concordia diagram for zircon samples from the Ruby geanticline and

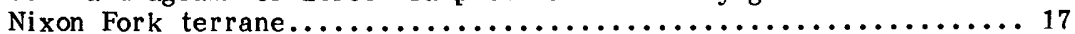

12.--Map showing distribution of carbonate rocks and sch ist, Kotzebue

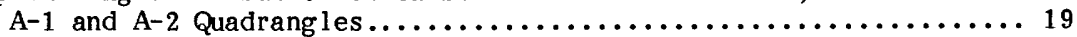

13.--Photograph of flat-lying, well-layered marble, with alternating fine and coarse crystalline layers (carbonate turbidites?)...... 20

14.--Photograph of carbonate breccia (debris flow?)................ 20

15.--Map showing regional relationships of rock units observed in Kotzebue $\mathrm{A}-1$ and $\mathrm{A}-2$ Quadrangles and similar rocks in central

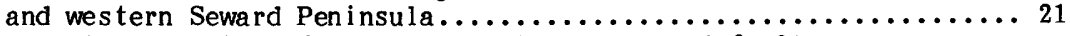

16.--Map showing location of major mountain ranges and faults of the southern Seward Peninsula, including the Windy Creek

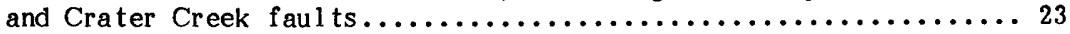

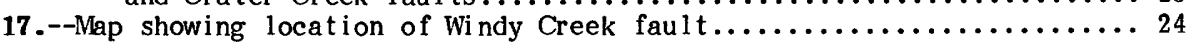

18.--Map showing location of Crater Creek fault .................. 25

19.--Map showing location of Paleozoic and Precambrian metamorphic rocks of west-central and southwestern Alaska.......26

20.--Map showing areas in east-central Alaska discussed

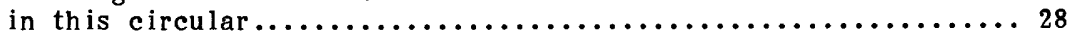

21.--Map showing the Mesozoic flysch belt, vitreous quartzite unit, and adjacent terranes in part of east-central Alaska........... 30

22.--Simplified geologic map of the Ray Mountains, Tanana and Bettles

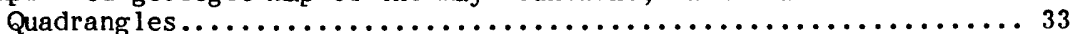

23.--Simplified structure map of the Ray Mountains, Tanana and Bettles

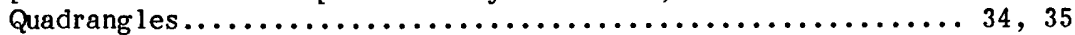

24.--Sketches of super imposed mesoscopic structures............... 36

25.--Stereograms of structural data, southeastern Ray Mountains......... 37

26.--Contoured stereograms of structural data from schist, metabasite, and marble, northwestern part of Ray Mountains metamorphic suite.. 38

27.--Photograph of overturned fold in Cretaceous(?) nonmar ine sedimentary rocks in the nor thern Tanacross Quadrangle......... 39

28.--Photograph of a fold in Cretaceous(?) nonmar ine sedimentary rocks.... 39

29.--Photograph of a small thrust fault in folded Cretaceous(?)

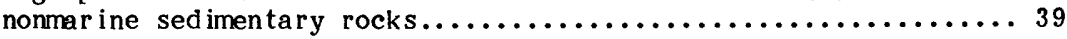

30.--Map showing location and approximate boundaries of areas included

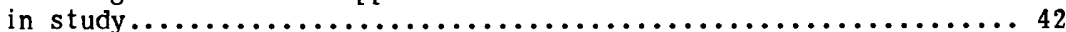

31.--Map showing generalized geology of the Table Mountain area and classification of some of the drainage basins based on the ir discriminant scores............................ 43

32.--Map showing generalized geology of the Circle mining district area and classification of the drainage basins based on their

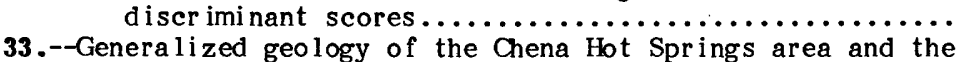
classification of drainage basins based on their

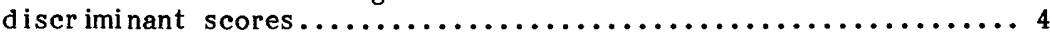

34.-- Index map showing location of the southeastern Yukon-Koyukuk ophiolite belt and of the map segments shown in figure $35 \ldots \ldots \ldots 46$

35.--Generalized geologic maps of the southeastern Yukon-Koyukuk ophiolite belt .................................. 47

36.--Map showing areas in southwestern Alaska discussed in this circular .................................... 49 
37.--Map showing location of measured section and distribution of

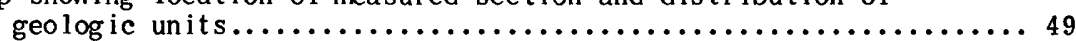

38.--Diagram showing generalized type section of the Kaguyak Formation.... 50

39.--Diagram showing Late Jurassic Buchia zones and stratigraphic distribution of species on the Alaska Pen insula.............. 51

40.--Map showing fossil locality, main geographic features in the study area, and the boundary of the Lime Hi 11 s Quadrangle...... 53

41.--Generalized geologic map showing extent of structural discontinuity on the southern Alaska Pen insula............... 54

42.--Photograph of structurally disrupted zone located nor theast of the point on the east side of Humpback Bay .............. 55

43.--Photograph of structurally disrupted zone to the north of

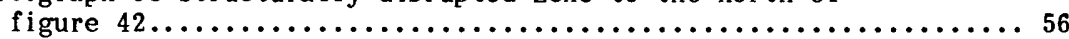

44.--Map showing Mount Veniaminof and surrounding area, including

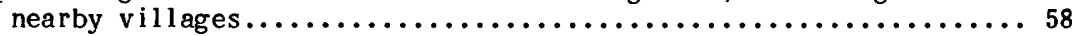

45.--Map showing location of newly discovered volcanic vents relative to Mbunt Kupreanof.......................... 61

46.--Photograph of flow ridges on lava flows from vent 1 on the divide between Grub Gulch and Bear Lake....................... 62

47. --Map showing areas in southern Alaska discussed in th is circular..... 62

48.--Concordia plot of $\mathrm{Pb} / \mathrm{U}$ data from seven splits of zircon from

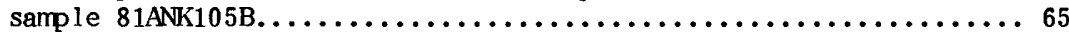

49.--Diag ram of internal $\mathrm{Rb}-\mathrm{Sr}$ isochron of $102 \pm 2 \mathrm{~m} . \mathrm{y}$. from

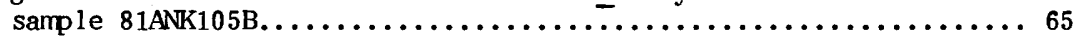

50.--Maps showing geophysical contours, super imposed faults of the Denali and related systems, as well as recognized

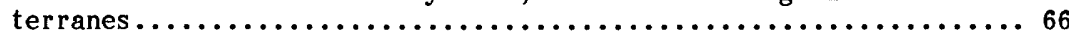

51.--Outline map of Mount Hayes Quadrangle showing location of profile $A-A^{\prime}$ and boundaries of terranes mentioned in the text....66

52.--Diagram of magnet ic model of profile $A-A^{\prime}$; Gulkana batholith is truncated by Denali fault........................... 69

53.--Diag rams of magnet ic models (a,b) of profile A-A'; Gulkana batholith extends to a great depth or the Denali fault

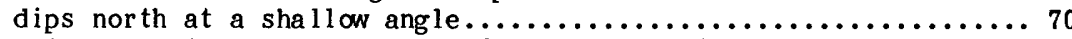

54.--Lead-isotope diagram showing the field of data for massive sulfide deposits from the Jarvis Creek Glacier terrane, the Slana River subterrane, and the Denali mine............. 72

55.--Map showing outcrop localities of the Chugach terrane and the Yakutat Group, faults in part of southern Alaska,

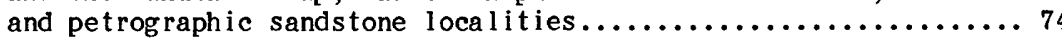

56.--Diagram showing results of petrographic analyses of sandstones of the Yakutat Group from the Malaspina

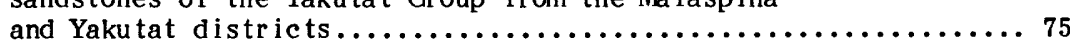

57.--Simplified geologic map of parts of the Mbunt Hayes C-4 to $\mathrm{C}-6$ Quadrang les, eastern Al aska Range................. 78

58.--Map showing epicenters of Columbia Bay ma in shocks and we 11 located aftershocks ......................... 81

59.--Cross sections of Columbia Bay main shocks and we 11 -located aftershocks............................ 81

60.--Map showing locations of earthquakes of magnitude $5 \mathrm{~m}$ and larger that occurred in southern Alaska between October 1982 and September $1983 \ldots \ldots \ldots \ldots \ldots \ldots \ldots \ldots \ldots \ldots \ldots$ 
61.--Map showing seismicity in southern Alaska, October 1, 1982, to September $30,1983 \ldots \ldots \ldots \ldots \ldots \ldots \ldots \ldots \ldots \ldots \ldots \ldots \ldots \ldots$

62.--Map showing areas in southeastern Alaska discussed

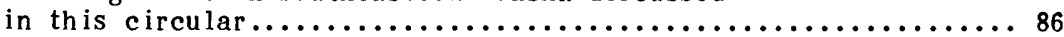

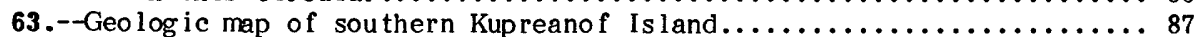

64.--Topographic map of the Big Sore deposit area in the Greens Creek water shed.................................. 89

65.--Map of study area, which includes most of the Petersburg Quadrangle and the easternmost part of the Port Alexander

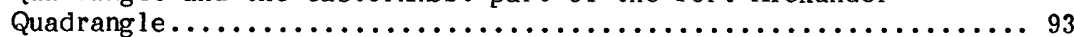

66.--Map of dra inage into Kadake Bay, Kuiu Is land, showing sampling locations of minus -80 mesh stream and mudflats sediments and total $\mathrm{Ou}$ concentrations of these sediments........94

67.--Map of dra inage into Meter Bight, Zarembo Is land, showing sampling locations of minus -80 mesh stream and mudflat sediments and total $\mathrm{Cu}$ concentrations of these sediments........94

68.--Diagram of dissolved metal concentrations as a function of salinity in water from St. John Harbor, Zarembo Is land....... 94

69.--Diagram showing the $\mathrm{Pb}$-isotopic data from volcanogen ic massive sulfides from the Sweetheart Ridge and the Greens Creek deposits and from a crosscutting

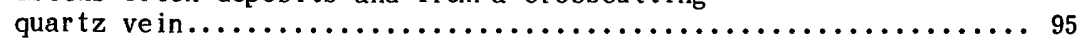

70.--Map showing location of the Holkham Bay area in southeastern Al aska and map of Holkham Bay ............... 97

71.--Histogram of FeS content in sphaler ite from the Sumdum prospect..... 98

72.--Map showing areas of offshore Alaska discussed in this circular......99

73.--Diag ram of est imated volumes of sediment disruption in $1-\mathrm{m}$ water depth intervals for two shelf morphologies in eastern

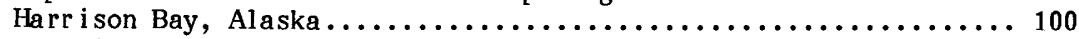

74.--Map showing locations of boreholes and high resolution

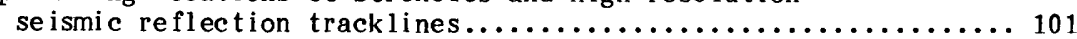

75.--Correlation diagrams, from west to east, of boreholes HLA 16-20, showing generalized sedimentary character, position of prominent reflectors, and un it designations ............. 102

76.--Correlation diagrams, from west to east, of boreholes HLA 14

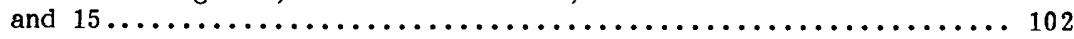

\section{TABLES}

Table 1.--ICP analysis of selected elements in a deionized water suspension containing approximately $10^{7}$ B. cereus spores per milliliter..... 3

2.--Trace elements of placer gold.......................... 7

3.--K-Ar isotopic analyses by Alaska Division of Geological and Geophysical Surveys, University of Alaska, Fairbanks Cooperative Geochronology Laboratory.

4.--U-Pb isotopic ages from analyses using a mixed ${ }^{235} \mathrm{U}-{ }^{205} \mathrm{~Pb}$ spike and methods described in Krogh (1973) and Dillon and

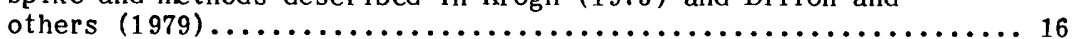

5.--Conodont-based age determinations from the Kotzebue Coast ......... 22

6.--Potassium-argon age determinations from rocks near VABM Idono........ 27

7.--Coefficients of discriminant functions .................... 41 
TABLES-continued

8.--Results of classification of samples from the Lime Peak and Mount $\mathrm{Pr}$ indle areas.................................... 41

9.--Species of the pelecypod Buchia of Late Jurassic age on the

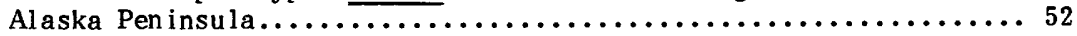

10.--Ana lytical results of samples from Mount Veniami nof.............59

11.--Uranium-lead isotopic data for zircon from meta-granodiorite in the Lake George terrane, Mount Hayes Quadrangle............6 63

12.--Results of analyses for rubidium and strontium................64

13.--Parameters for interpreted bodies shown in figures 52 and $53 \ldots \ldots \ldots 71$

14.--Mean gra in compositions of Yakutat Group sandstones from the Ma laspina and Yakutat districts.......................... 75

15.--Framework gra in compositions in the Yakutat Group, Malaspina

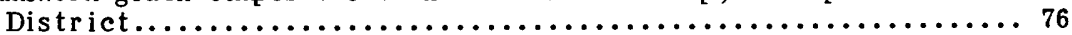

16.--Framework gra in compositions in the Yakutat Group, Yakutat

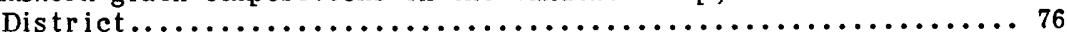

17.--Massive sulfide occurrences, Jarvis Creek Glacier terrane, western Mount Hayes Quadrangle, eastern Alaska Range...........79

18.--Source parameters for the 1983 Columbia Bay ma in earthquakes.......80

19.--Magnitude $5 \mathrm{M}$ and larger earthquakes in southern Alaska,

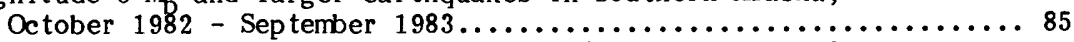

20.-- Element concentration of aquatic mosses from the Greens Creek

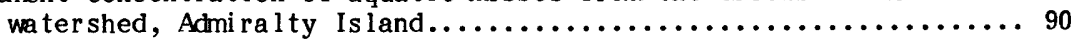

Any use of trade names and trademarks in this circular is for descriptive purposes only and does not constitute endorsement by the U.S. Geological Survey. Underlining items in the text in most instances substitutes for italic typography and is not for emphasis. Where English units were used in making the original measurements, they have been retained to avoid some inaccuracies of conversion. 



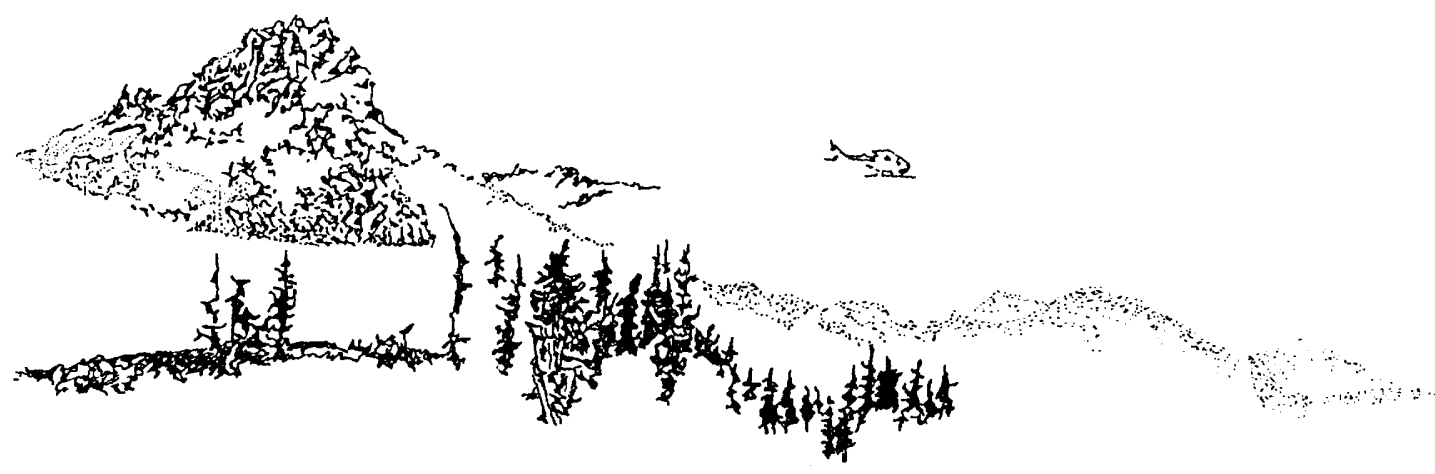

\title{
THE UNITED STATES GEOLOGICAL SURVEY IN ALASKA: ACCOMPLISHMENTS DURING 1983
}

\author{
Susan Bartsch-Winkler and Katherine M. Reed, Editors
}

\begin{abstract}
This circular contains short reports about many of the geologic studies carried out in Alaska by the U.S. Geological Survey and cooperating agencies during 1983. The topics cover a wide range in scientific and economic interest.
\end{abstract}

\section{INTRODUCTION}

The U.S. Geological Survey investigates various geological aspects of the onshore and offshore areas of Alaska. These studies range in scope from topical investigations to statewide and reconnaissance regional assessments and include a variety of topics. This circular contains short reports derived from some of these studies carried out by the U.S. Geological Survey and cooperating agencies or organizations during 1983. An author index of included reports and a topical crossreference are appended at the back of the volume. These will assist the reader in locating work by specific authors or about a particular topic. A complete listing of U.S. Geological Survey published reports about Alaska produced in 1983 can be found in Publications of the Geological Survey, 1983. Single copies of this listing are distributed free by application to the Branch of Distribution, U.S. Geological Survey, 604 South Pickett Street, Alexandria, VA 22034.

The reports are presented in the order of their occurrence: first, those investigations that discuss statewide or large regional areas; second, those that were undertaken in each of the six regional subdivisions of Alaska from north to south; and third, those that investigate the offshore areas. The subdivisions are shown in figure 1. Index maps showing the individual study areas are included near the beginning of each section.

\section{STATEWIDE ALASKA \\ EVID ENCE THAT GOLD CRYSTALS CAN NUCLEATE ON BACTERIAL SPORES}

\author{
by John R. Watterson, James M. Nishi, \\ and Theodore Botinelly
}

Experiments conducted in the Geological Survey's Denver laboratories in 1983 revealed that gold crystals can nucleate on common micron-sized bacterial spores that have come into contact with aqueous gold. Initially, gold precipitates uniformly on the nearly spherical surfaces of the spores, but as layers of crystalline gold progressively envelop a spore, the spore-centered crystal may assume the shape of a pentagonally faced dodecahedron. The amount of gold deposited on Bacillus cereus spores from solutions of aqueous gold chloride $\left(\mathrm{AuCl}_{4}{ }^{-}\right.$) increased with time of exposure and in proportion to the concentration of gold in the aqueous solutions. The laboratory-grown gold crystals appear to be indistinguishable from dodecahedral gold crystals found in nature (fig. 2).

Germination of B. cereus spores was shown to be inhibited by solutions of mercury, copper, chromium, and iron salts (Krishna Murty and Halvorson, 1957) through binding of these metal cations to the spore surface. Our interest in the possibility that gold crystals might nucleate on B. cereus spores began when we learned during routine tests that ionic gold likewise inhibits the germination of these spores.

Spores of a laboratory isolate of $B$. cereus (K-2) were grown on Plate Count agar at $30^{\circ} \mathrm{C}$ for at least one week and stored in distilled water at $5^{\circ} \mathrm{C}$. Individual batches of spores were washed as needed by repeated centrifuging from deionized 


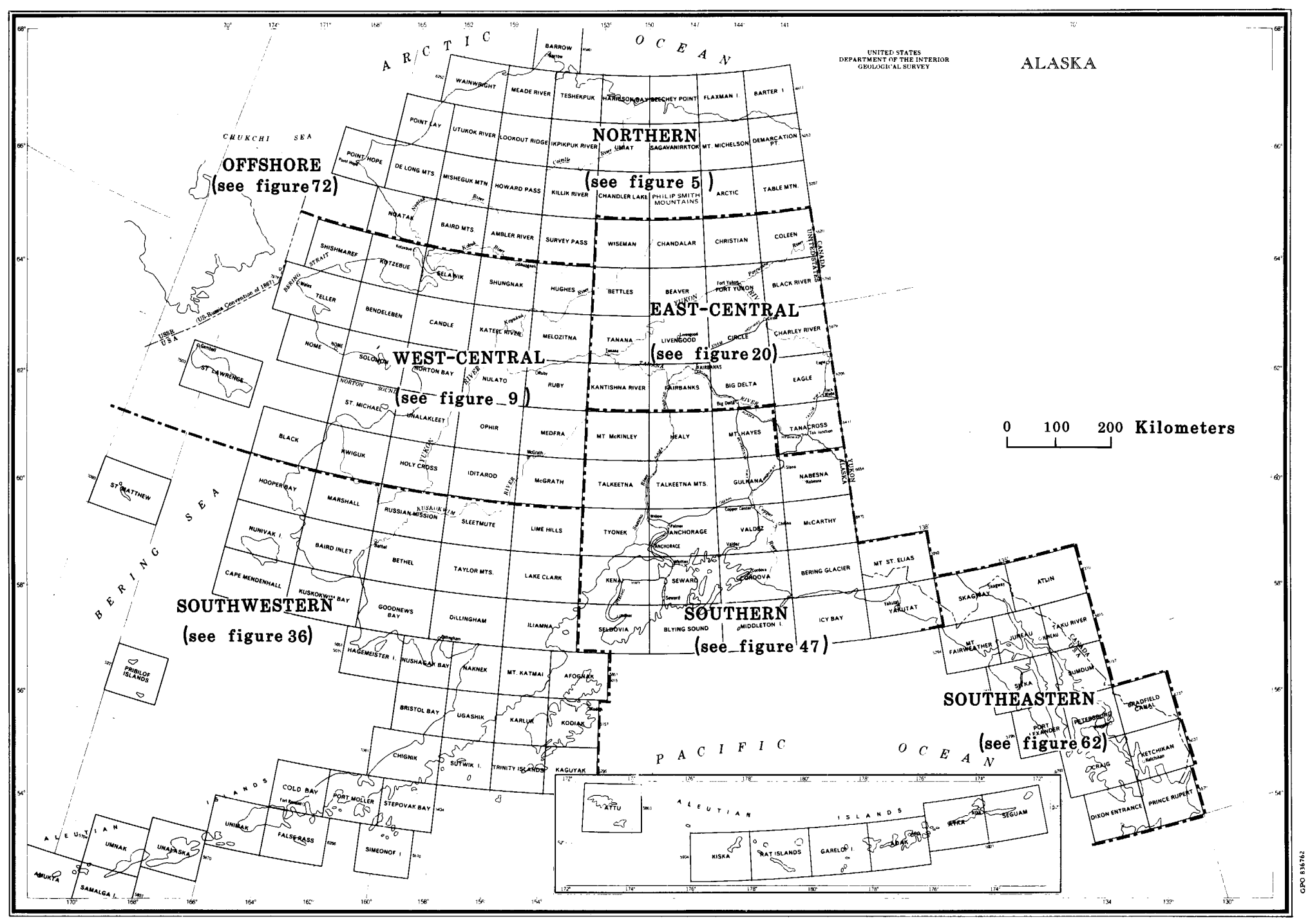

Figure 1.--Regions of Alaska used in this circular. Referenced figures indicate regional index maps that show areas discussed. 


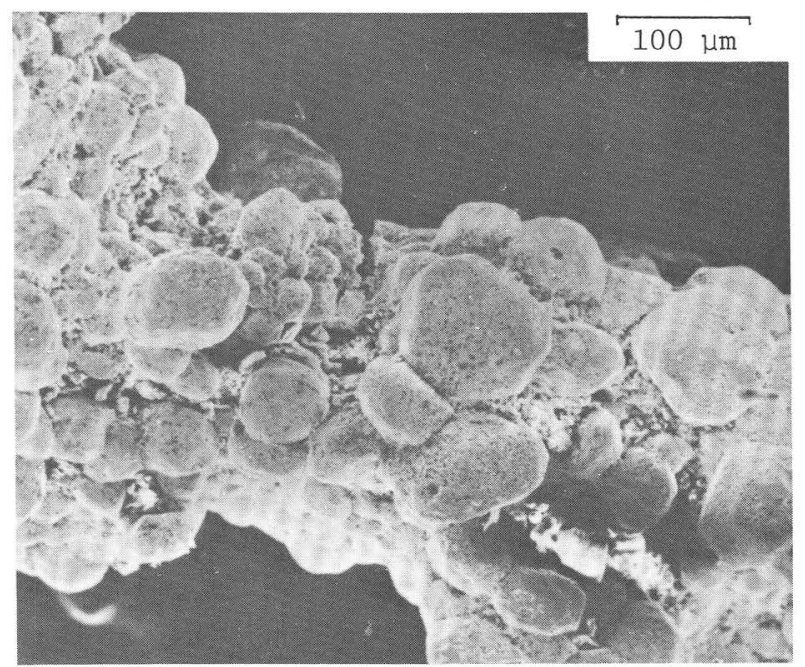

Figure 2.--SEM photograph of part of a tiny gold nugget found near Sacramento, California, and donated by William L. Miller of Sacramento. The nugget consists of intergrown dodecahedra.

water. Fisher atomic absorption gold reference standard, which contains 1,000 micrograms of gold per $\mathrm{ml}$ as the chloride $\left(\mathrm{AuCl}_{4}{ }^{-}\right)$in distilled water (pH 2.65), was used at full strength or diluted with deionized water. X-ray diffraction patterns were obtained using a Gandolfi $x$-ray diffraction camera. Chemical analyses (table 1) were carried out by means of inductively coupled plasma emission spectrometry (ICP). A scanning electron microscope (SEM) equipped with an energydispersive $\mathrm{x}$-ray fluorescence (EDX) detector was used to photograph spores and make chemical identification of microscopic crystals.

In one experiment, duplicate quantities of approximately $10^{8}$ spores were suspended in 1,000 micrograms/ml gold solution for 14 hours, washed free of soluble gold by repeated centrifuging from deionized water, and dried in a laminar flow hood. $\mathrm{X}$-ray diffraction analysis (fig. 3 ) confirmed that microcrystalline gold was present in the spore precipitate; however, SEM examination of the precipitate revealed nothing but recognizable bacterial spores. No crystalline material was present. Randomly picked spores examined in EDX spot analysis showed similar, strong gold spectra. A thin, uniform film of metallic gold had been deposited on all spores so examined.

To learn if the deposition of gold on spores was proportional to the concentration of aqueous gold, aliquots containing approximately $10^{8}$ spores were added to a series of solutions of gold ranging from 25 to $1,000 \mathrm{micrograms} / \mathrm{ml}$, allowed to react for 14 hours, washed free of soluble gold as above, and resuspended in deionized water. ICP analysis of each suspension (table 1) confirmed that deposition of gold on spore surfaces was proportional to the concentration of gold in solution.
Finally, approximately $0.25 \mathrm{~g}$ of washed spores was added to $20 \mathrm{ml}$ of $1,000 \mathrm{micrograms} / \mathrm{ml}$ gold solution, and this sample, along with a control sample containing no spores, were gently agitated for 36 hours on a wrist-action shaker. While the control sample contained no precipitate, a fine precipitate was observed in the culture tube to which spores had been added. After rinsing and drying, this precipitate was mounted on an SEM stub with a conducting resin. Many crystalline objects ranging in size from 1 micron to approximately 15 microns in diameter were observed and were confirmed by EDX spot analysis to consist of gold. Two such crystals clearly appear to have grown on bacterial spores (fig. 4). Adjacent spores exhibiting irregular surface accumulations of gold, as shown by EDX spot analysis, are indicated by arrows (figs. $4 \mathrm{~A}, \mathrm{~B})$. Other apparently naked spores are also present (fig. 4A).

On the basis of preliminary chemical data, Watterson and others (1983) hypothesized that gold was chemically replacing barium, calcium, and strontium in spore material perhaps as deep as the cortex. Recent studies, however, do not support that hypothesis (table 1), and we now conclude that gold interacts primarily with the spore coat.

Table 1.--ICP analysis of selected elements in a deionized water suspension containing approximately $10^{7}$ B. cereus spores per milliliter. Spore aliquots were previously exposed for 14 hours to gold solutions $\left(\mathrm{AuCl}_{4}{ }^{-}\right)$of the indicated concentrations

\begin{tabular}{rrrrr}
\hline $\begin{array}{c}\text { Gold } \\
\text { Gn test } \\
\text { solution } \\
\text { (Micrograms } \\
\text { per ml) }\end{array}$ & \multicolumn{5}{c}{$\begin{array}{c}\text { Analysis of spore } \\
\text { suspension (ppm) }\end{array}$} \\
\cline { 2 - 5 } & $\mathrm{Au}$ & $\mathrm{Ba}$ & $\mathrm{Ca}$ & $\mathrm{Sr}$ \\
\hline 0 & 0.07 & 0.006 & 2.0 & 0.007 \\
25 & 3.89 & .006 & 2.0 & .006 \\
50 & 6.81 & .004 & 2.0 & .007 \\
100 & 7.90 & .002 & 2.0 & .006 \\
200 & 7.69 & .002 & 2.0 & .006 \\
300 & 8.00 & .001 & 2.0 & .006 \\
400 & 8.86 & .002 & 1.0 & .005 \\
500 & 8.42 & .001 & 1.0 & .005 \\
600 & 8.93 & .002 & 2.0 & .006 \\
700 & 9.82 & .001 & 2.0 & .005 \\
800 & 12.43 & .002 & 2.0 & .007 \\
900 & 14.05 & .002 & 2.0 & .006 \\
1000 & 13.84 & .001 & 2.0 & .006 \\
\hline
\end{tabular}




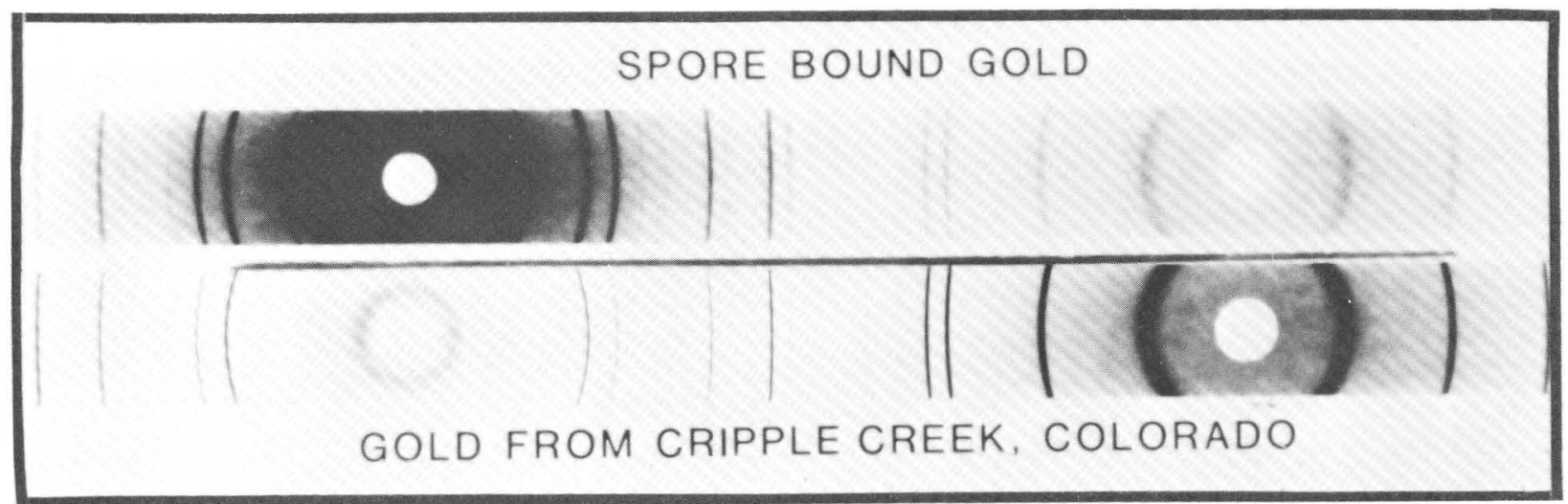

Figure 3.-X-ray diffraction patterns of (top) B. cereus spores after overnight exposure to 1,000 micrograms/ml aqueous gold chloride $\left(\mathrm{AuCl}_{4}{ }^{-}\right)$solution and (bottom) a gold standard from Cripple Creek, Colorado.

The B. cereus spore coat consists of waterinsoluble, sulfur-rich, keratin-like proteins rich in cystine and half-cystine crosslinkages (Aaronson and Pandy, 1977). We have calculated from the data of Aaronson and Fitz-James (1976) that as many as $5 \mathrm{x}$ $10^{6}$ such linking groups are present and may be chemically accessible in the outer 100 angstroms of each $B$. cereus spore. These sulfur linkages presumably can act as local electron donors and active binding sites for transition metal cations (Greenstein and Winitz, 1961) and may account for the reversible metal cation binding demonstrated by Krishna Murty and Halvorson (1957). Beveridge (1978) demonstrated the formation of tiny gold crystals within purified $B$. subtilis cell wall preparations after a few minutes exposure to $5 \mathrm{mM}$ (millimolar) $\mathrm{AuCl}_{4}{ }^{-}$.

This report and one presented earlier (Watterson and others, 1983) are apparently the first to note the ability of bacterial spores to nucleate gold crystals. The resemblance between dodecahedral gold crystals grown on common B. cereus spores under laboratory conditions (fig. 4) and dodecahedral gold crystals found in nature (fig. 2) raises the possibility, but does not necessarily indicate, that a similar process occurs in nature.

\section{REFERENCES CITED}

Aaronson, A. I., and Fitz-James, P., 1976, Structure and morphogenesis of the bacterial spore coat: Bacteriological Reviews, v. 40, p. $360-$ 402.

Aaronson, A. I., and Pandy, N. K., 1977, Comparative structural and functional aspects of spore coats, p. 54-61 in Chambliss, G., and Vary, J. C. (eds.), Spores VII: Washington D. C., American Society for Microbiology, 354 p.

Beveridge, T. J., 1978, The response of cell walls of Bacillus subtilis to metals and to electron microscopic stains: Canadian Journal of Microbiology, v. 24, p. 89-104.

Greenstein, J. P., and Winitz, M., 1961, Chemistry of the amino acids, v. I, (p. 643-645): New York, John Wiley and Sons, 760 p.

Krishna Murty, G. G., and Halvorson, H. O., 1957, Effects of enzyme inhibitors on the germination of and growth from Bacillus cereus var. terminalis spores: Journal of Bacteriology, v. 73, p. 230-234.

Watterson, J. R., Antweiler, J. C., and Campbell, W. L., 1983, Bug nuggets: International Symposium on Environmental Biogeochemistry, 6th, Santa Fe, NM, October 10-14, 1983, Program and Abstracts, p. 24.

Reviewers: J. C. Antweiler and J. B. Cathrall

\section{TRACE ELEMENTS OF PLACER GOLD}

\section{by Warren Yeend}

Samples of placer gold from selected localities in Alaska were analyzed for their traceelement content with the hope that individual element concentrations would be distinctive enough to differentiate the samples from various mining districts -in other words, to "fingerprint" the gold. Table 2 shows trace elements present in 20 samples collected in Alaska and, for comparative purposes, 3 placer samples from the Tertiary gold-bearing gravel of the Sierra Nevada in California. Values of all elements are reported in parts per million (except silver, which is reported in percent). Analyses of the samples were made by Elwin Mosier (U.S. Geological Survey, Denver, Colo.), using the method described in Mosier (1975). All samples analyzed are from present-day stream beds, except two from weathered Tertiary(?) conglomerate in the Mount Hayes Quadrangle. 

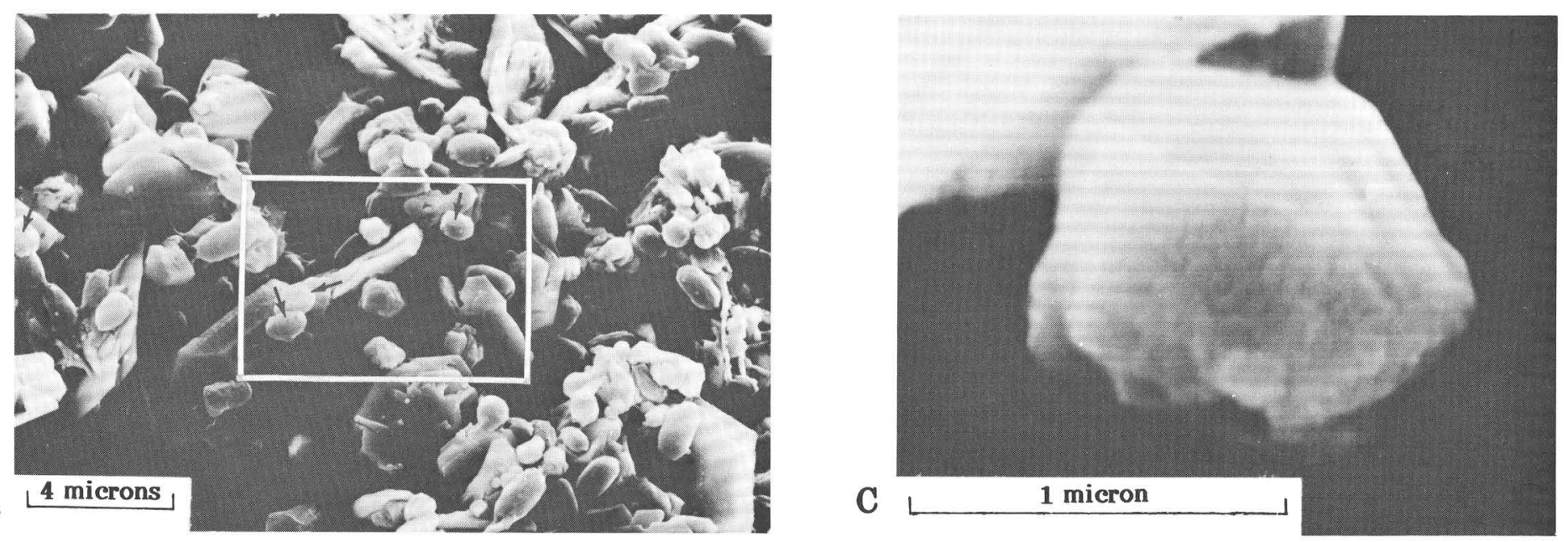

or
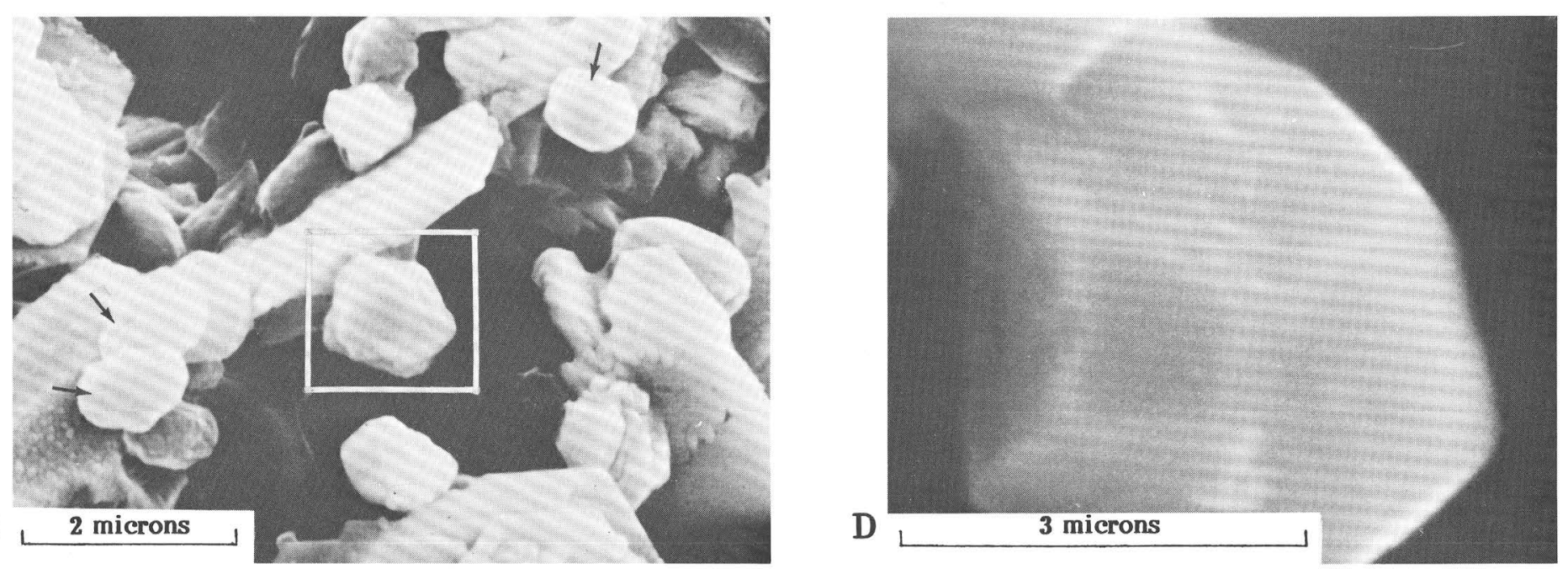

Figure 4.--SEM photographs of resultant gold-coated B. cereus spores after 36-hour exposure to $1,000 \mathrm{microgram} / \mathrm{ml}$ aqueous gold chloride $\left(\mathrm{AuCl}_{4}^{-}\right)$. Squares (A and B) outline areas photographed in $\mathrm{B}$ and $\mathrm{C}$, respectively. Arrows (A and B) point to other spores with EDX-identified surface gold accumulations. D-Highly charged 3-micron gold particle that has already assumed dodecahedral form. 
Table 2.--Trace elements of placer gold. All elements are recorded in parts per million,

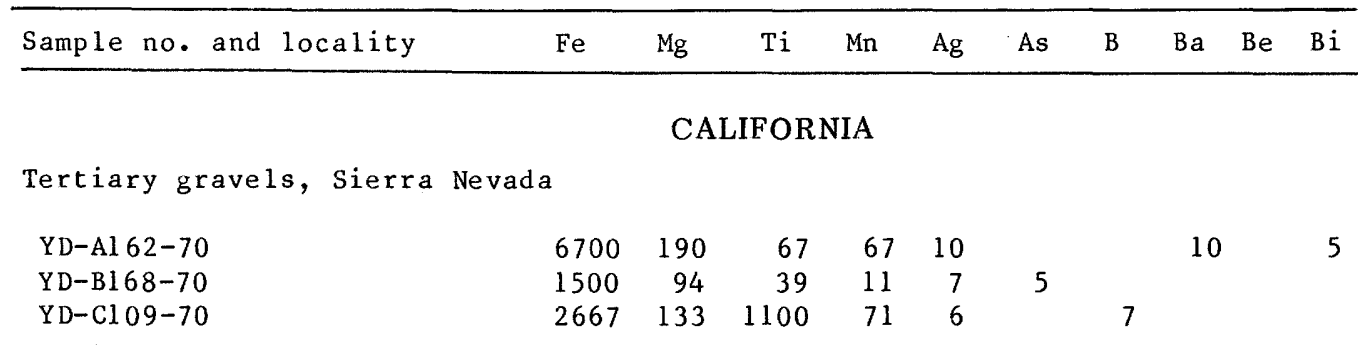

ALASKA

Mount Hayes Quadrangle (Chistochina district)

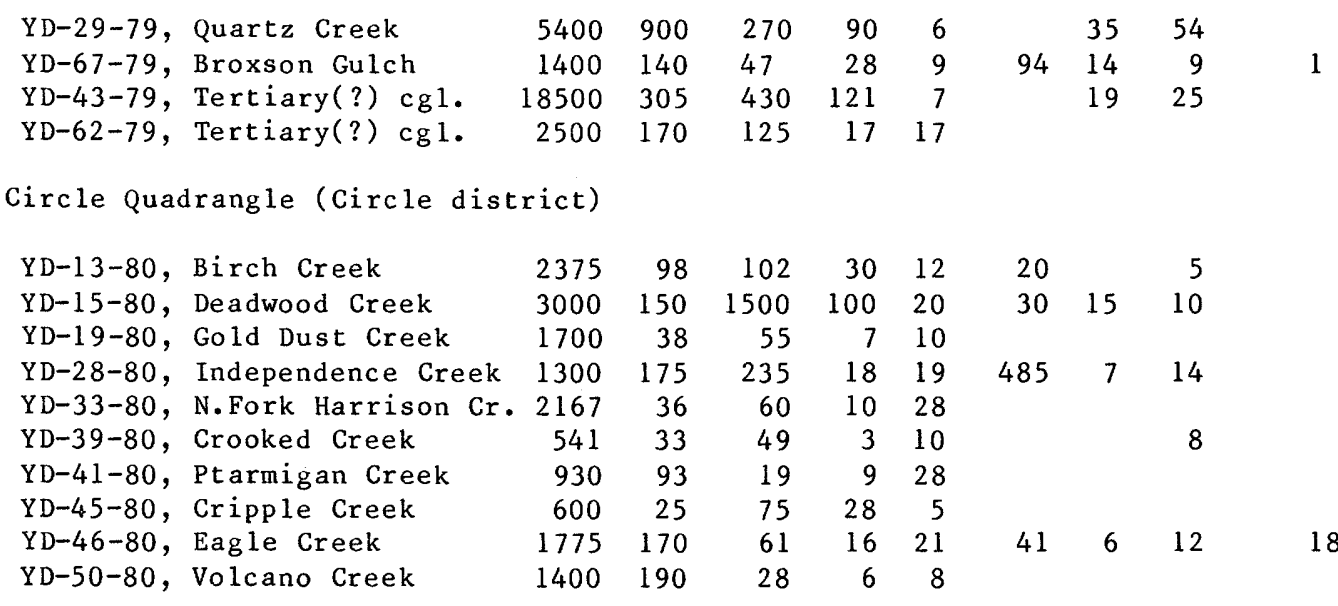

Charley River Quadrangle (Circle district)

$\begin{array}{llllllllll}\text { YD-59-80, Coal Creek } & 3200 & 55 & 58 & 20 & 12 & 3 & 11 & 4\end{array}$

Healy Quadrangle (Valdez Creek district)

$\begin{array}{lrrrrrrrr}\text { YD-59-80, Valdez Creek } & 1600 & 220 & 330 & 22 & 8 & & & 16 \\ & & & & & & & & \\ \text { Ophir Quadrangle (Innoko district) } & & & & & & & \\ & & & & & & & & \\ \text { YD-67-80, Spruce Creek } & 3125 & 42 & 55 & 8 & 8 & 25 & 8 & .5 \\ \text { YD-68-80, Spruce Creek } & 4750 & 50 & 41 & 18 & 13 & 23 & 5 & 30 \\ \text { YD-69-80, Anvil Creek } & 828 & 78 & 66 & 6 & 10 & & 3 & 24 \\ \text { YD-76-80, Colorado Creek } & 987 & 88 & 59 & 14 & 14 & 167 & 3 & 110\end{array}$

Examination of the data presented in table 2 provides the following conclusions:

(1) Gold samples from the Mount Hayes Quadrangle are characterized by high $\mathrm{Cu}$, medium $\mathrm{Ag}$ content (10 percent), and nil $\mathrm{Sb}$; the sample from the Tertiary(?) conglomerate (sample no. YD-43-79) from the Mount Hayes Quadrangle is characterized by very high $\mathrm{Fe}, \mathrm{Si}$, and $\mathrm{Hg}$, and moderately high $\mathrm{Mn}, \mathrm{Ti}, \mathrm{Mg}, \mathrm{V}$, and $\mathrm{Zr}$ values. The high values may be the result of oxide and other coatings deposited on the gold grains during the considerable time the grains were subjected to ground-water alteration and weathering.

(2) Gold from the Circle Quadrangle is characterized by moderately high $\mathrm{Ag}$ content (average 16.1 percent) and the presence of $\mathrm{Sb}$ in all samples. This contrasts markedly with almost all the other samples analyzed.

(3) Gold from the Ophir Quadrangle is characterized by moderately high $\mathrm{Ba}$ and $\mathrm{Cr}$ content (in 3 of the 4 samples). The sample from Colorado Creek has high $\mathrm{Pb}, \mathrm{Sb}$, and $\mathrm{Hg}$ content. 
except $\mathrm{Ag}$, which is recorded in percent. (Gold districts are from Cobb, 1973)

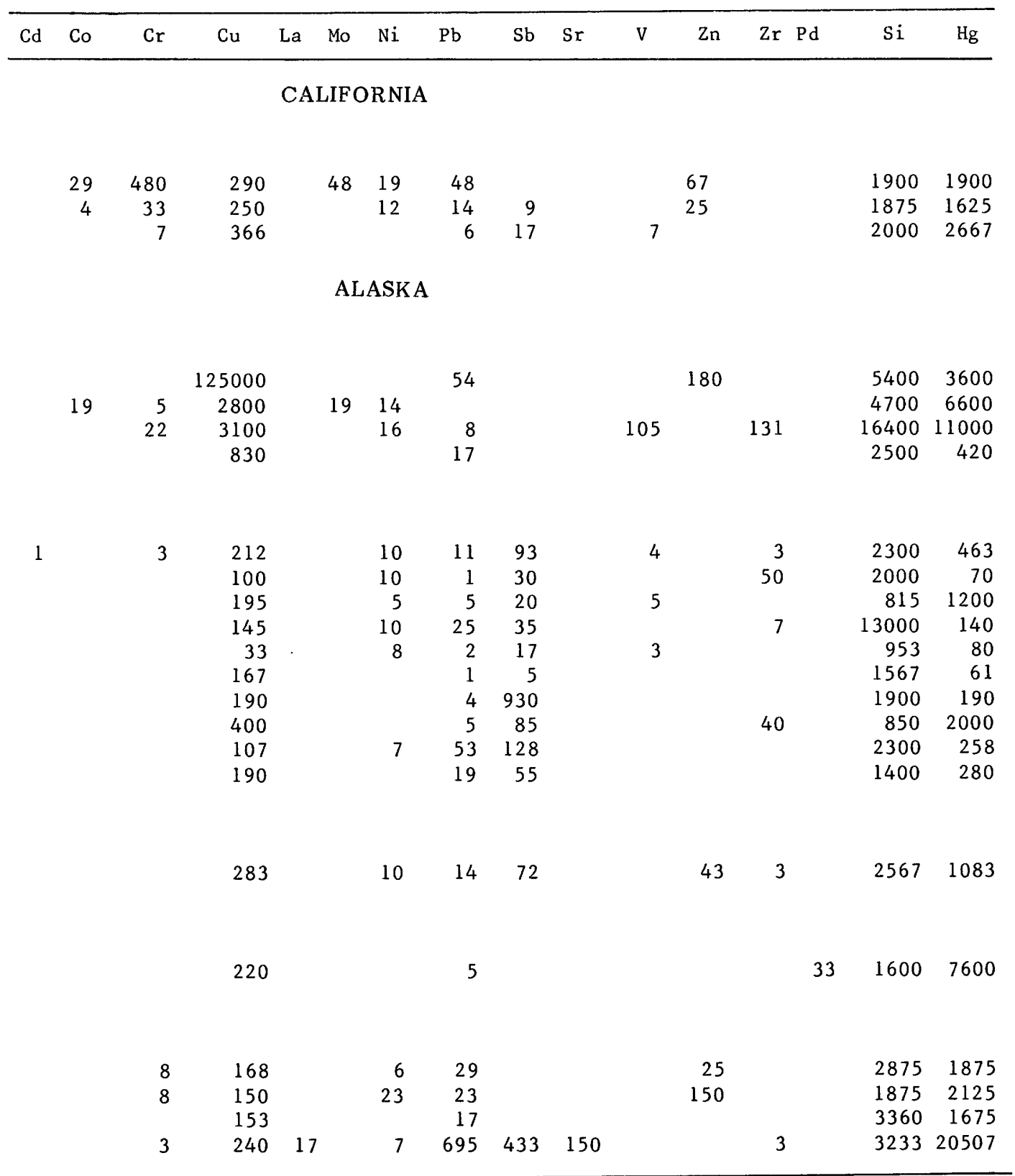

All these results are preliminary, and a substantial number of additional samples needs to be analyzed before more conclusive statements can be made. No explanation is given for the "anomalous" element concentrations, although further study of more placer and lode gold samples may provide some definitive explanation.
Geological Survey Bulletin 1324, 213 p.

Mosier, E. L., 1975, Use of emission spectroscopy for the semiquantitative analysis of trace elements and silver in native gold, in Ward, F. N. ed., New and refined methods of trace analysis useful in geochemical exploration: U.S. Geological Survey Bulletin 1408, p. 97-105.

\section{REFERENCES CITED}

Cobb, E. H., 1973, Placer deposits of Alaska: U.S. Reviewers: H. L. Foster and Bella Csejtey, Jr. 


\section{NORTHERN ALASKA}

(Figure 5 shows study areas described.)

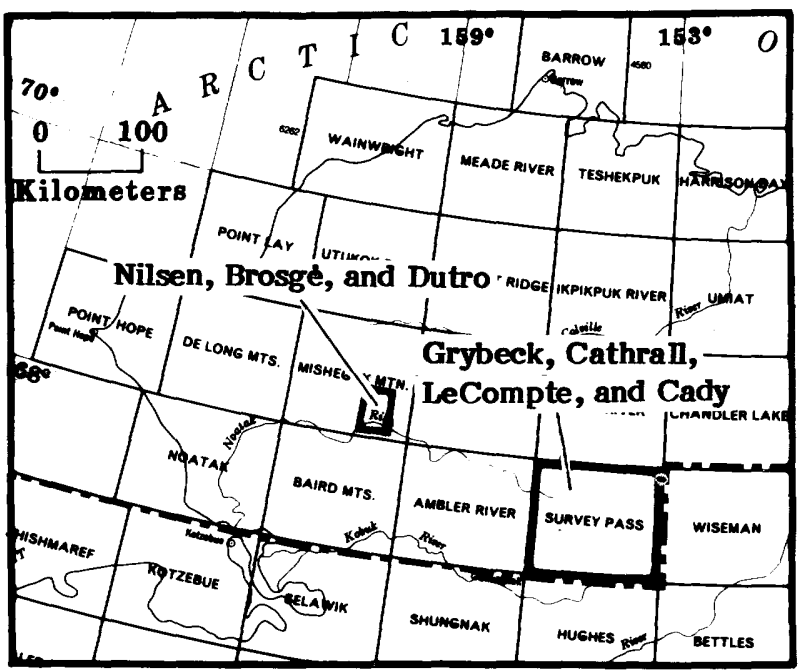

Figure 5.--Areas in northern Alaska discussed in this circular. Outlines define the areas described by the indicated authors.

\section{BURIED FELSIC PLUTONS IN UPPER DEVONIAN REDBEDS, CENTRAL BROOKS RANGE}

\section{by Donald J. Grybeck, John B. Cathrall, James R. LeCompte, and John W. Cady}

Several lines of evidence indicate that a buried felsic pluton occurs near the head of the Alatna River in the Survey Pass Quadrangle. The site of the suspected pluton is about $67^{\circ} 50$ 'N., $155^{\circ} 20^{\prime}$ W. (fig. 6). Its size is not known with certainty, but it is probably at least several kilometers in diameter and perhaps tens of kilometers deep, based on mineral deposit, geochemical, and remote-sensing evidence.

The suspected pluton occurs beneath a thick sequence of feldspathic wacke, with subordinate interbedded siliceous siltstone and dark-gray to black phyllite mapped as the upper member of the Hunt Fork Shale (Nelson and Grybeck, 1980). This sequence is particularly well-developed in the northern part of the Survey Pass Quadrangle. Its total thickness is obscured by folding and thrust faulting, but it is many hundreds, if not thousands, of meters thick. According to Nilsen's recent synthesis (1981), this upper sandstone member of the Hunt Fork Shale is the shallow-marine precursor of a thick Upper Devonian fluvial delta sequence represented by the Kanayut Conglomerate. Lithologically, the upper sandstone member more closely resembles typical Kanayut Conglomerate (sandstone facies in the Survey Pass Quadrangle) than the darkgray phyllite typical of most of the Hunt Fork
Shale. The upper sandstone member is confidently dated as Late Devonian (Famennian?) based on fossils identified and dated by Dutro and others from numerous localities (Nelson and Grybeck, 1980).

Initial interest in the area was triggered by several sulfide-bearing samples collected there by T. D. Hamilton (U.S. Geological Survey) in 1962. Subsequent searches in 1977 and 1978 located several small, apparently epigenetic, quartz veins and breccia zones that contain various combinations of sphalerite, galena, pyrite, and chalcopyrite (Grybeck and Nelson, 1981). Stream-sediment and heavy-mineral concentrate sampling revealed that the area is marked by a suite of elements characteristic of felsic plutonic rocks. The heavy-mineral samples, in particular, are markedly anomalous in various combinations of $\mathrm{Pb}, \mathrm{Zn}, \mathrm{Ag}, \mathrm{Sn}, \mathrm{W}, \mathrm{La}$, and Th (Cathrall and others, 1981).

Analysis of Landsat imagery reveals a welldeveloped pattern of arcuate features about $28 \mathrm{~km}$ in diameter centered on the area of the geochemical anomalies (Le Compte, 1981). These features are analogous to similar ones developed on the granite batholiths exposed in the Arrigetch Peaks and Mount Igikpak areas about $75 \mathrm{~km}$ to the southeast. The aeromagnetic data (Cady and Hackett, 1982) is permissive of a buried felsic pluton similar to the plutons to the south, but the magnetic signature of those plutons is indistinguishable from the signature of the Upper Devonian clastic rocks adjacent to the buried pluton.

A possible, similar, buried pluton may occur near Plateau Mountain in the Survey Pass Quadrangle (fig. 6). The evidence is somewhat less striking than, but similar to, that for the buried pluton at the head of the Alatna River; this evidence consists of the strong geochemical anomalies in a suite of felsic-plutonic elements and a circular pattern of arcuate features on Landsat imagery. The rocks near Plateau Mountain are a complex of thrustfaulted Upper Devonian and Mississippian black and gray phyllite, metaconglomerate, and limestone. For an area even farther to the east in the Philip Smith Mountains Quadrangle, Marsh and Cathrall (1981) have presented geochemical evidence that indicates buried felsic plutons, and Dillon (1982) has suggested that buried felsic plutons and related mineral deposits may be present throughout the central Brooks Range.

The ages of buried plutons in the Survey Pass Quadrangle are uncertain. The most likely equivalents are the Late Devonian and Early Mississippian granite batholiths exposed to the south in the Arrigetch Peaks and around Mount Igikpak (Dillon and others, 1980; Nelson and Grybeck, 1980). Cretaceous plutons are widely known south of the Brooks Range. Several plutons in the Brooks Range were previously thought to be Cretaceous on the basis of $\mathrm{K}$-Ar radiometric ages; however, the time of emplacement of all the plutons in the Brooks Range and in northern Alaska is now recognized to be mid- 


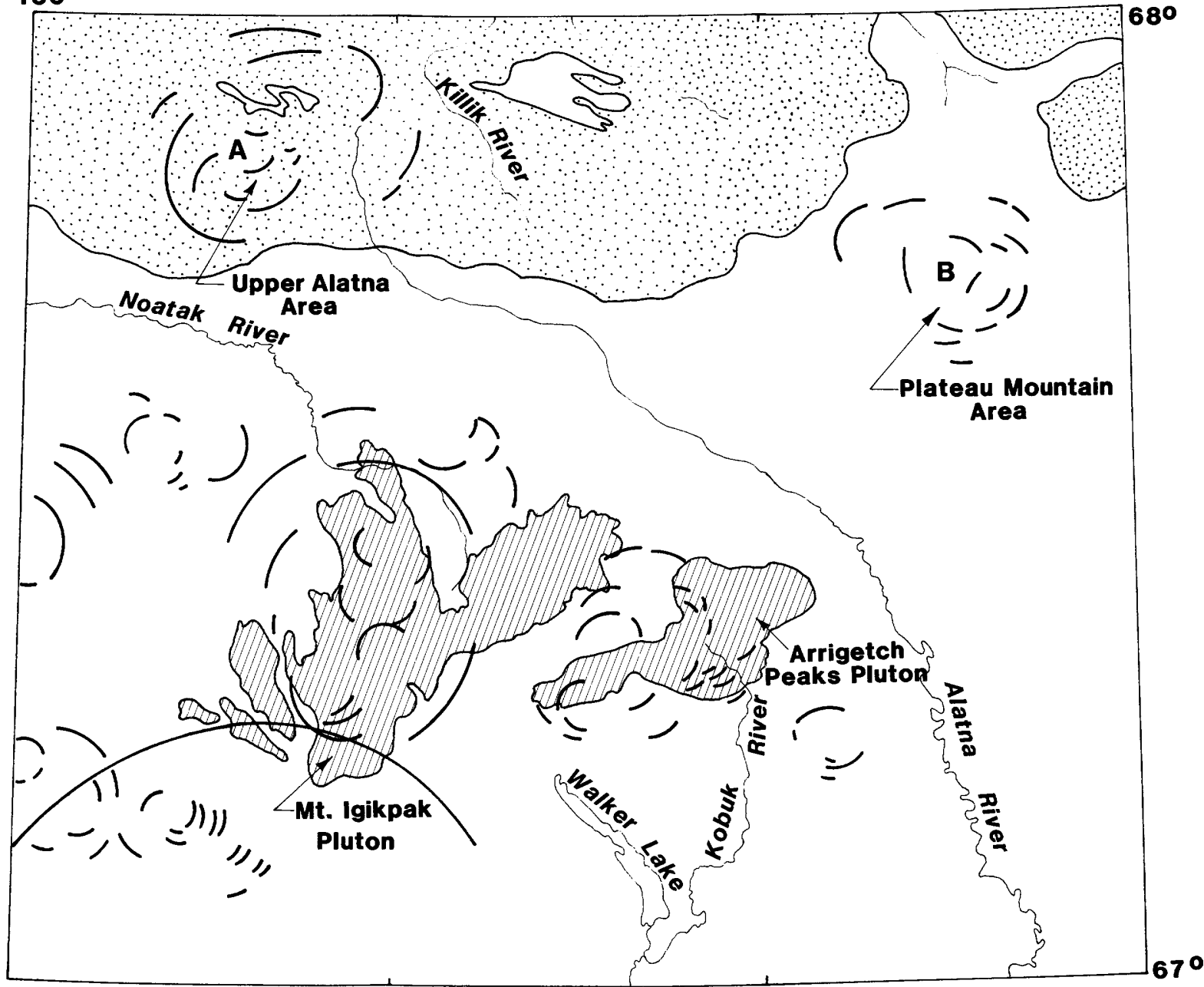

Figure 6.--Location of suspected buried felsic plutons in Survey Pass Quadrangle, Brooks Range. Stippled pattern is Devonian granite to granitic gneiss. Hachured pattern is upper Devonian redbed sequence, Kanayut Conglomerate, and upper sandstone member of the Hunt Fork Shale. Curved lines represent arcuate features identified on Landsat images.

dle Paleozoic or before (Dillon and others, 1980).

The contact zones have not been observed; therefore, the intrusive relationship of the proposed buried plutons to the Upper Devonian clastic rocks is uncertain. However, the occurrence of epigenetic sulfide-quartz veins and the associated geochemical anomalies at the head of the Alatna River suggest an intrusive contact, even though contact metamorphic effects are absent at the surface. The mineral deposits and geochemical anomalies could represent metals remobilized from a hypothetical buried granite of any age from Precambrian to Tertiary. The least complicated explanation is that the proposed buried felsic plutons range in age from Late Devonian to Early Mississippian and intrude Upper Devonian clastic rocks.
The presence of these buried plutons has several implications. They provide attractive possibilities for mineral deposits, especially because their roof zones are preserved at depth and the associated mineralization processes were at least sufficient to produce geochemical aureoles that contain several elements of economic interest. The plutons also suggest the possibility that more complex processes took place in Late Devonian time in the Brooks Range than have been previously recognized. As noted, Late Devonian and Early Mississippian granitic plutons and a Late Devonian delta or clastic wedge are well documented, but they occur in geologically distinet terranes separated by known or suspected faults or unconformities. An intrusive relationship of the suspected buried plutons in the 
Survey Pass Quadrangle raises the possibility that, soon after its deposition, the Late Devonian delta of the central Brooks Range was intruded by large felsic plutons.

\section{REFERENCES CITED}

Cady, J. W., and Hackett, S. W., 1982, Maps showing aeromagnetic survey and interpretation of the Survey Pass Quadrangle, Brooks Range, Alaska: U.S. Geological Survey Miscellaneous Field Studies Map MF-1176-G, scale $1: 250,000,3$ sheets.

Cathrall, J. S., Billings, T. M., Cooley, E. F., and O'Leary, R. M., 1981, Maps showing anomalous drainage areas of selected elements in the Survey Pass Quadrangle, Brooks Range, Alaska: U.S. Geological Survey Miscellaneous Field Studies Map MF-1176-D, scale 1:250,000, 1 sheet.

Dillon, J. T., 1982, Source of lode- and placer-gold deposits of the Chandalar and upper Koyukuk districts, Alaska: Alaska Division of Geological and Geophysical Surveys Open-File Report 158, 22 p.

Dillon, J. T., Pessel, G. H., Chen, G. H., and Veach, N. C., 1980, Middle Paleozoic magmatism and orogenesis in the Brooks Range, Alaska: Geology, v. 8, p. 338-343.

Grybeck, D. J., and Nelson, S. W., 1981, Mineral deposits of the Survey Pass Quadrangle, Brooks Range, Alaska: U.S. Geological Survey Miscellaneous Field Studies Map MF-1176-F, scale 1:250,000, 1 sheet.

Le Compte, J. R., 1981, Maps showing interpretation of Landsat imagery of the Survey Pass Quadrangle, Brooks Range, Alaska: U.S. Geological Survey Miscellaneous Field Studies Map MF-1176-H, scale $1: 250,000,2$ sheets.

Marsh, S. P., and Cathrall, J. B., 1981, Geochemical evidence for a Brooks Range mineral belt: Journal of Geochemical Exploration, v. 15, p. 367-380.

Nelson, S. W., and Grybeck, D. J., 1980, Geologic map of the Survey Pass Quadrangle, Brooks Range, Alaska: U.S. Geological Survey Miscellaneous Field Studies Map MF-1176-A, scale $1: 250,000,2$ sheets.

Nilsen, T. H., 1981, Upper Devonian and Lower Mississippian redbeds, Brooks Range, Alaska: Geological Association of Canada Special Paper 23, p. 187-219.

Reviewers: J. H. Dover and J. S. Kelley

\section{NEW REFERENCE SECTION OF THE NOATAK SANDSTONE, NIMIUTUK RIVER, MISHEGUK MOUNTAIN QUADRANGLE, CENTRAL BROOKS RANGE}

\author{
by Tor H. Nilsen, William P. Brosgé, \\ and J. Thomas Dutro, Jr.
}

A 296-m-thick section was measured during the summer of 1983 in the type area of the Noatak Sandstone (section 1, figs. 7, 8). The type area of the Noatak Sandstone was designated by Dutro (1952; 1953a, b), following earlier work by Smith $(1913$, p. 70$)$ and Smith and Mertie (1930, p. 165), to

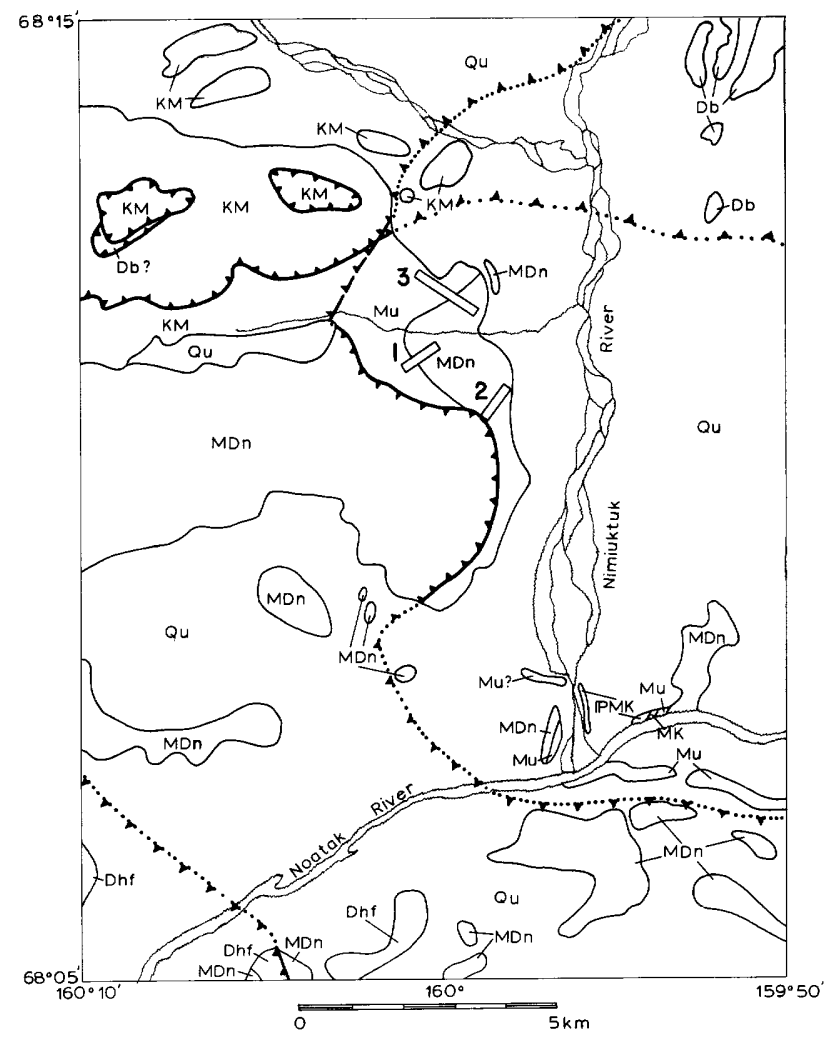

Figure 7.-- Geologic map showing location of measured sections of the Noatak Sandstone: 1 , new reference section described in this report; 2 , type section of Dutro (1952); 3, reference section of Dutro (1952). Abbreviations: Db, Baird Group, limestone (Devonian); Dhf, Hunt Fork Shale (Devonian); MDn, Noatak Sandstone (Devonian and Mississippian); Mu, Utukok Formation (Mississippian); Mk, Kayak Shale (Mississippian); PMk, Kuna Formation (Mississippian and Pennsylvanian); KM, sedimentary and volcanic rocks (Mississippian through Cretaceous); $\mathrm{Qu}$, surficial deposits (Quaternary). Barbed lines are thrust faults, dotted where concealed. Geology modified from Ellersieck and others (1982), Mayfield and others (1982), and Dutro (1952). 


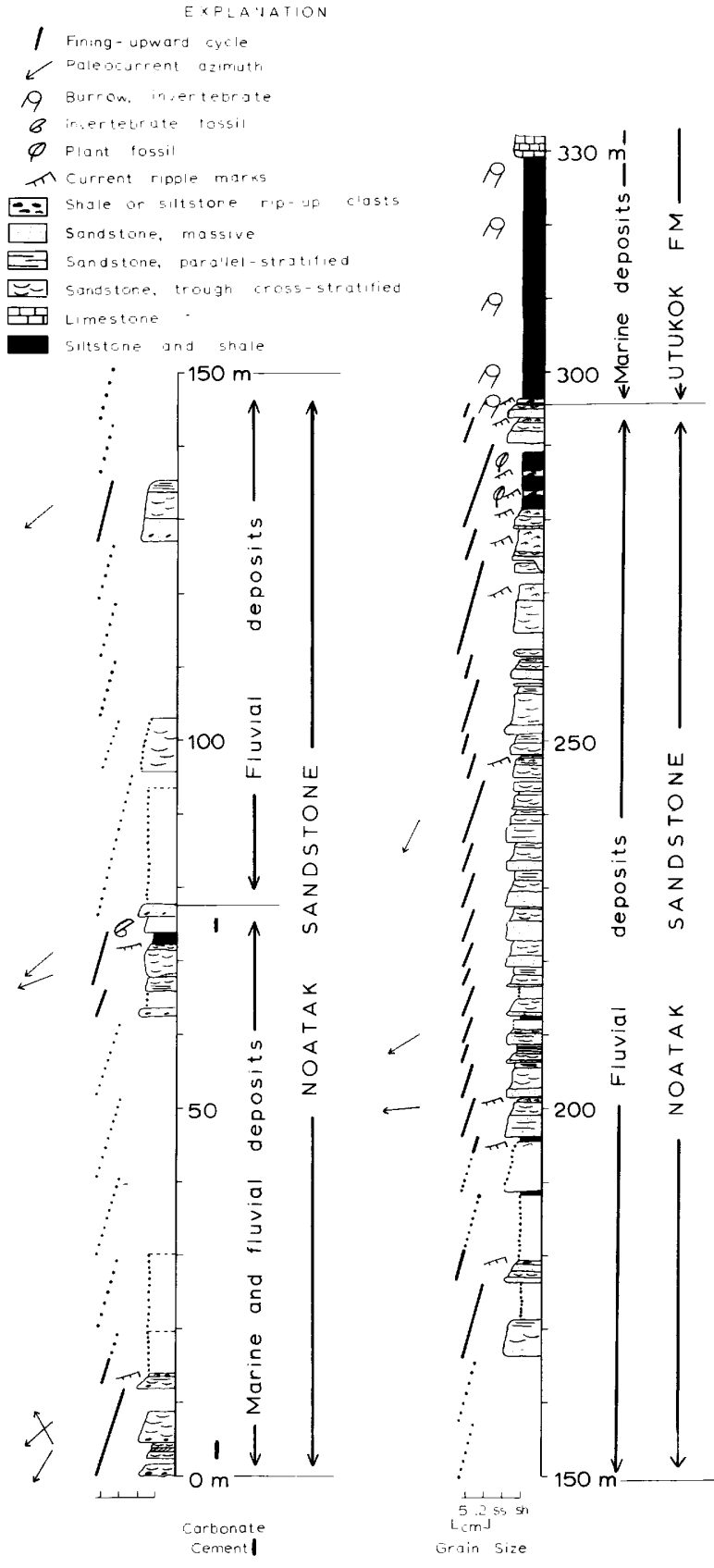

Figure 8.--New reference section of Noatak Sandstone measured in 1983 (shown as section 1, fig. 7). Intervals of the section that are blank are completely covered, and those that are dotted are partially covered.

be north and west of the confluence of the Nimiuktuk and Noatak Rivers, Misheguk Mountain Quadrangle, eastern De Long Mountains, western Brooks Range. Dutro (1952) measured two incomplete sections of Noatak Sandstone at the type area (fig. 7); he designated the first (section 2, fig. 7) as the type section, and the second (section 3, fig. 7) is generally considered to be a reference section. Dutro correlated the Noatak Sandstone with the Kanayut Conglomerate of the central Brooks Range. However, detailed measurement of our section (section 1, fig. 7) and comparison of it with numerous measured sections of Kanayut Conglomerate to the east and west of the Nimiuktuk River area indicate that Dutro's reference section of the Noatak Sandstone includes fluvial deposits more characteristic of the Kanayut Conglomerate, as later defined by Bowsher and Dutro (1957) and redefined by Nilsen and Moore (1984).

Dutro's two measured sections of Noatak Sandstone do not completely describe it because (1) the basal contact with the underlying Upper Devonian Hunt Fork Shale is not present in either section, (2) the upper contact of the type section is faulted, and (3) the complete thickness of the Noatak Sandstone cannot be determined. Our new section, here designated a reference section, does not contain the basal contact either, but is thicker than both of Dutro's sections and has a clearly defined and gradational upper contact with the Mississippian Utukok Formation. Because of its stratigraphic sequence, mostly fluvial character, and similarity to related stratigraphic sequences in the eastern, central, and western Brooks Range (Nilsen and Moore, 1982a), we suggest that the fluvial rocks in the new reference section could be regarded as the fine-grained distal facies of the Kanayut Conglomerate.

The Noatak Sandstone in the central Brooks Range is a laterally discontinuous marine sandstone that is $0-560 \mathrm{~m}$ thick (Nilsen and Moore, 1982b). It conformably overlies the marine Hunt Fork Shale and conformably underlies the nonmarine Ear Peak Member of the Kanayut Conglomerate (Nilsen and Moore, 1984). The Noatak contains middle Famennian (late Late Devonian) marine megafossils, including brachiopods, gastropods, pelecypods, and echinoderms, as well as trace fossils, such as Skolithos, that are indicative of shelf, intertidal, lagoonal, and marginal-marine depositional environments (Nilsen and others, 1980).

The Noatak Sandstone in the central Brooks Range consists of medium-bedded, fine- to mediumgrained, quartzose sandstone that locally contains pebble conglomerate and thin shale intervals. The Noatak typically forms massive outcrops with alternating thicker beds of trough-cross-stratified sandstone and thinner beds of planar-stratified sandstone. In some areas, thickening- and coarseningupward bundles of sandstone as thick as $15 \mathrm{~m}$ are present. These bundles may result from offshore progradation of stream-mouth bars or other shelfto-shoreline sand accumulations. The sandstone characteristically contains calcite cement, causing it to be somewhat less resistant than the overlying silica-cemented orthoquartzitic sandstone of the 
Kanayut Conglomerate. The calcareous cement yields numerous concretionary areas which, upon weathering, leave the rock with irregular surfaces marked by limonitic residues. Highly variable paleocurrent orientations characterize the Noatak Sandstone (Nilsen and others, 1980), probably as a result of variable directions of storm, tidal, wind, and wave-generated shelf currents.

The Kanayut Conglomerate, in contrast, is a nonmarine sequence that conformably and gradationally overlies the Noatak Sandstone. It is laterally continuous and as thick as $3,000 \mathrm{~m}$; it was deposited as a large fluvial-dominated delta system that prograded southwestward in the Late Devonian over the marine rocks of the Noatak Sandstone and Hunt Fork Shale. It contains plant fossils indicative of a Late Devonian and Early Mississippian age. The lower part of the Ear Peak Member of the Kanayut Conglomerate is stratigraphically organized into repetitive 5- to-20-m-thick, fining-upward cycles that consist, in ascending order, of massive conglomerate resting with an erosive contact on shale, crudely parallel-stratified conglomeratic sandstone, troughcross-stratified sandstone, ripple-marked and laminated very fine grained sandstone and siltstone, and shale with local paleosols and in-place plant fossils. These fining-upward cycles represent the depositional record of stream channels that migrated across their associated flood plains. The conglomerate and sandstone of the Kanayut Conglomerate is characteristically orthoquartzitic and typically lacks calcareous cement. Paleocurrent directions in the fluvial deposits have fairly consistent orientations toward the southwest. Thus, the Kanayut is more resistant than the underlying Noatak, contains a different superposition of bedding types, and has a more uniform southwesterly orientation of paleocurrents.

The new reference section measured west of the Nimiuktuk River (section 1, fig. 7) contains strata with almost all of the characteristics of the Kanayut Conglomerate. Except for the lower $76 \mathrm{~m}$, which contain a few calcareous beds, a marine megafossil about $75 \mathrm{~m}$ above the base, irregular cyclicity, and some paleocurrent variability (characteristics more typical of the Noatak Sandstone), most of the section consists of orthoquartzitic sandstone and interbedded shale. The calcareous beds and fossiliferous bed probably indicate the interval of gradual interfingering of the underlying marine Noatak Sandstone with the overlying nonmarine Kanayut Conglomerate, as shown by Moore and Nilsen (1982a) for other parts of the central and western Brooks Range. The new reference section above the basal $76 \mathrm{~m}$ is organized into clearly developed fining- and thinning-upward cycles that resemble the fluvial cycles of the Kanayut Conglomerate. About 34 cycles, with an average thickness of about $6.5 \mathrm{~m}$, were measured and estimated in exposed and covered intervals above the basal $76 \mathrm{~m}$. Only plant fragments were found in this part of the section. Paleocurrent directions, measured chiefly from the plunges of trough axes, are consistently toward the southwest.

It seems clear that Dutro's reference section of the Noatak Sandstone, which can be correlated with our new reference section, consists mostly of nonmarine strata. It is also possible that Dutro's type section of the Noatak Sandstone may contain characteristic facies and interfingering beds of the Kanayut Conglomerate. As mapped by Dutro (1952), the type area of the Noatak Sandstone includes an indeterminate thickness of fossiliferous marine sandstone between the fluvial facies at the top of the reference section and the Hunt Fork Shale below. Dominantly fluvial strata that are facies equivalents of the Kanayut Conglomerate appear to almost always overlie marine units of the Noatak Sandstone, even in the westernmost Brooks Range (Mayfield and others, 1978; Nilsen and Moore, 1982b). A new reference section for the Noatak Sandstone is needed that can identify the fluvial and marine parts of the rock unit, define the base and top, and permit it to be distinguished regionally from the Kanayut Conglomerate. Such a section, as yet unmeasured, is available near the Eli River about $100 \mathrm{~km}$ southwest of the type section (lat. $67^{\circ} 40^{\prime} \mathrm{N}$., long. $161^{\circ} 44^{\prime} \mathrm{W}$.); here, about $150 \mathrm{~m}$ of nonmarine sandstone overlies about $150 \mathrm{~m}$ of marine sandstone.

\section{REFERENCES CITED}

Bowsher, A. L., and Dutro, J. T., Jr., 1957, The Paleozoic section in the Shainin Lake area, central Brooks Range, Alaska: U.S. Geological Survey Professional Paper 303-A, 39 p.

Dutro, J. T., Jr., 1952, Stratigraphy and paleontology of the Noatak and associated formations, Brooks Range, Alaska: U.S. Geological Survey Geological Investigations, Naval Petroleum Reserve No. 4, Alaska, Special Report $33,154 \mathrm{p}$.

Dutro, J. T. Jr., 1953a, Stratigraphy and paleontology of the Noatak and associated formations, Brooks Range, Alaska (abs.): Geological Society of America Bulletin, v. 64, no. 12, pt. 2, p. 14-15.

Dutro, J. T. Jr., 1953b, Stratigraphy and paleontology of the Noatak and associated formations, Brooks Range, Alaska: New Haven, Conn., Yale University, $\mathrm{Ph}$. D. dissertation, $154 \mathrm{p}$.

Ellersieck, Inyo, Curtis, S. M., Mayfield, C. F., and Tailleur, I. L., 1982, Reconnaissance geologic map of south-central Misheguk Mountain Quadrangle, Alaska: U.S. Geological Survey Open-File Report 82-612, scale 1:63,360.

Mayfield, C. F., Curtis, S. M., Ellersieck, Inyo, and Tailleur, I. L., 1982, Reconnaissance geologic map of southeastern Misheguk Mountain Quadrangle, Alaska: U.S. Geological Survey OpenFile Report 82-613, scale 1:63,360. 
Mayfield, C. F., Tailleur, I. L., Mull, C. G., and Sable, E. G., 1978, Bedrock geologic map of the south half of National Petroleum Reserve in Alaska: U. S. Geological Survey Open-File Report 78-70-B, scale 1:500,000, two sheets.

Nilsen, T. H., and Moore, T. E., 1982a, Stratigraphy and sedimentology of the Kanayut Conglomerate, central and western Brooks Range, Alaska-report of 1981 field season: U. S. Geological Survey Open-File Report 81-674, $64 \mathrm{p}$.

Nilsen, T. H., and Moore, T. E., 1982b, Fluvialfacies model for the Upper Devonian and Lower Mississippian(?) Kanayut Conglomerate, Brooks Range, Alaska, in Embry, A. F., and Balkwill, H. R., eds., Arctic Geology and Geophysics: Canadian Society of Petroleum Geologists Memoir 8, p. 1-12.

Nilsen, T. H., and Moore, T. E., 1984, Stratigraphic nomenclature for the Upper Devonian and Lower Mississippian(?) Kanayut Conglomerate, Brooks Range, Alaska: U. S. Geological Survey Bulletin 1529-A, p. A1-A64.

Nilsen, T. H., Moore, T. E., Dutro, J. T., Jr., Brosge, W. P., and Orchard, D. M., 1980, Sedimentology and stratigraphy of the Kanayut Conglomerate and associated units, central and eastern Brooks Range, Alaska-report of 1978 field season: U. S. Geological Survey OpenFile Report 80-888, 40 p.

Smith, P. S., 1913, The Noatak-Kobuk region, Alaska: U. S. Geological Survey Bulletin 536, $160 \mathrm{p}$.

Smith, P. S., and Mertie, J. B., Jr., 1930, Geology and mineral resources of northwestern Alaska: U. S. Geological Survey Bulletin 815, 351 p.

Reviewers: J. A. Bartow and Inyo Ellersieck

WEST-CENTRAL ALASKA

(Figure 9 shows study areas described.)

NEW RADIOMETRIC EVIDENCE FOR THE
AGE AND THERMAL HISTORY
OF THE METAMOR PHIC ROCKS OF THE
RUBY AND NIXON FORK TERRANES,
WEST-CENTRAL ALASKA

by John T. Dillon, William W. Patton, Jr., Samuel B. Mukasa, George R. Tilton, Joel Blum, and Elizabeth J. Mon ${ }^{1}$

Metamorphic rocks in central Alaska have been assigned to several tectonostratigraphic terranes by Jones and others (1981), but the protolith

1 Current addresses: Dillon and Blum: Alaska Division of Geological and Geophysical Surveys, Fairbanks, AK 99701; Patton and Moll, U.S.

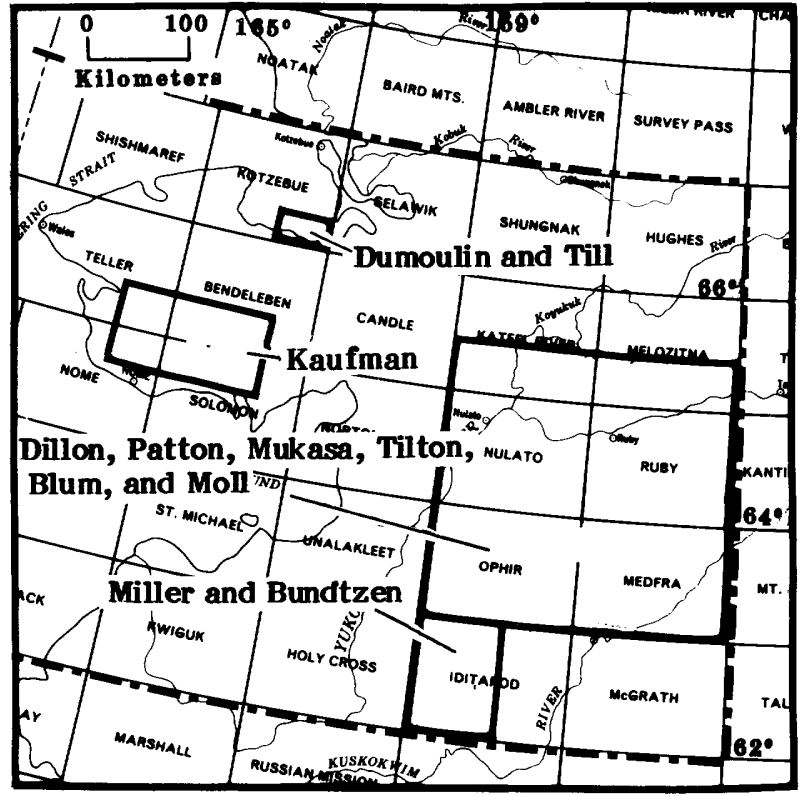

Figure 9.--Areas in west-central Alaska discussed in this circular. Outlines define the areas described by the indicated authors.

ages and histories of these rocks are poorly known. Sufficient radiometric data do not presently exist to adequately define these terranes. In this report, new $\mathrm{U}-\mathrm{Pb}$ and $\mathrm{K}-\mathrm{Ar}$ evidence is presented that characterizes and delimits the assemblages of metamorphic rocks in two of these terranes, the Ruby and Nixon Fork.

The Ruby terrane consists of greenschistand amphibolite-facies metasedimentary and felsic metaplutonic rocks. These metamorphic rocks compose the so-called "Ruby geanticline" that borders the southeastern edge of the Yukon-Koyukuk basin from the Brooks Range in the north to at least the Kaiyuh Mountains in the south. The southeastern limit of the Ruby terrane along most of the length of the "Ruby geanticline" is poorly defined because of lack of exposures and definitive geologic map data. However, in the region between the Yukon and upper Kuskokwim Rivers (fig. 10), the metamorphic rocks have been traced southeastward from the margin of the Yukon-Koyukuk basin to the Susulatna fault, where they appear to be juxtaposed with the Nixon Fork terrane (Patton and Moll, 1982).

Scattered fossil collections from carbonate rocks intercalated with pelitic schist of the Ruby terrane (Mertie and Harrington, 1924; Brosge and others, 1973; Chapman and others, 1982; Patton,

Geological Survey, Menlo Park, CA 94025; Mukasa and Tilton, Dept. of Geol. Sciences, Univ. of Calif., Santa Barbara, CA 93016. 


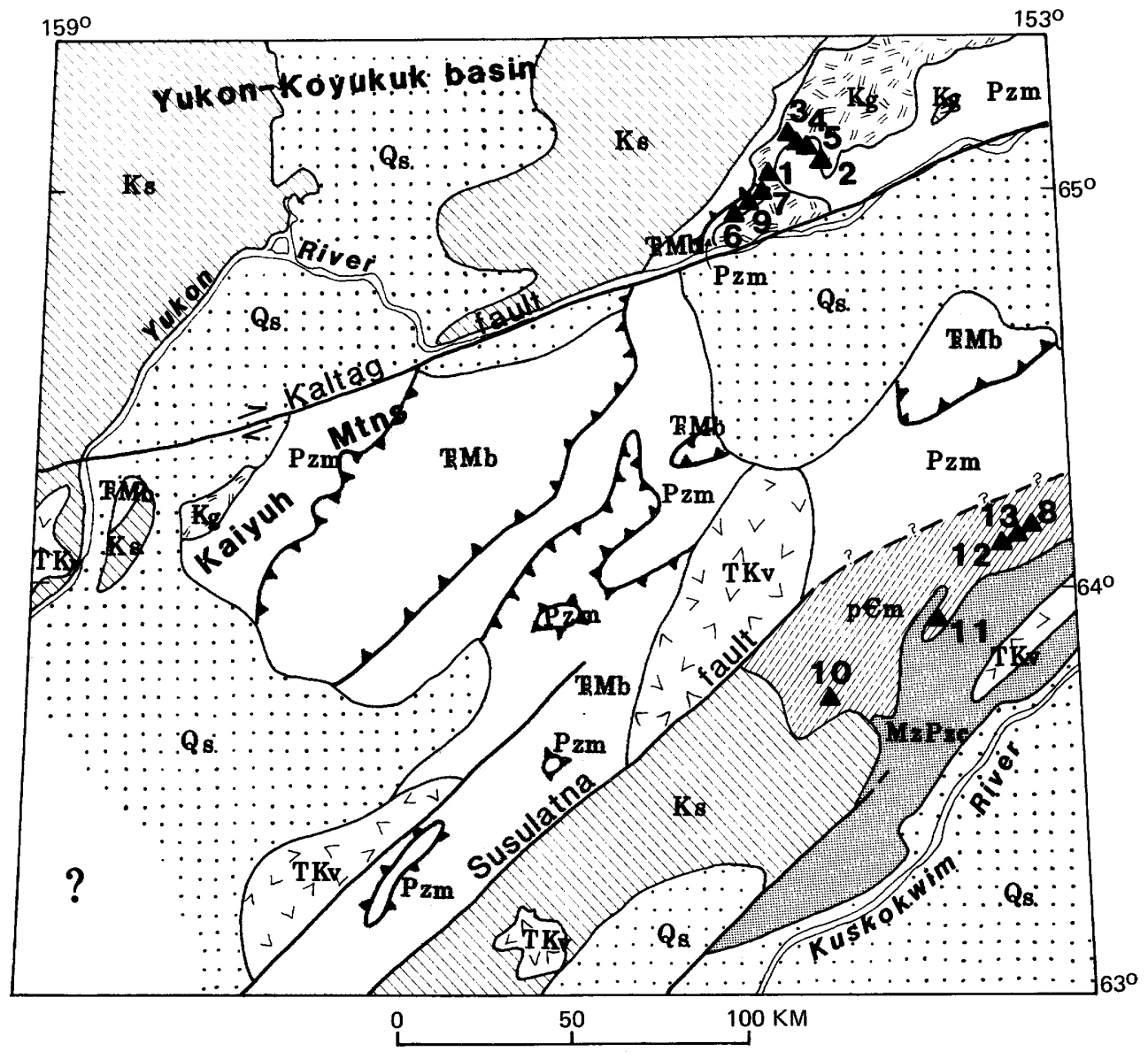

EXPLANATION

$\because \mathbf{Q} \mathbf{s}$ Surficial deposits (Quaternary)

口 T $\mathrm{T} 女$ Volcanic rocks (Tertiary and Cretaceous)

Terrigenous sedimentary rocks -- Yukon-Koyukuk and Kuskokwim basins (Cretaceous)

s
$\Delta^{8}$ Sample localities, number refers to list in tables $\mathbf{3}$ and $\mathbf{4}$

\section{$\int$ Contact}

High angle fault

Thrust fault

RMb Basalt, chert, gabbro, and ultramafic rocks -- Angayucham, Innoko, and Tozitna terranes (Triassic to Mississippian)

Carbonate rocks and terrigenous sedimentary rocks -Nixon Fork terrane (Mesozoic and Paleozoic)

Pzm Metasedimentary and metaplutonic rocks -- Ruby terrane (Paleozoic)

Metasedimentary and metavolcanic rocks -- Nixon Fork terrane (Precambrian)

Figure 10.--Sketch map of the geology of the Yukon-upper Kuskokwim Rivers region. 
Table 3. - K-Ar isotopic analyses by Alaska Division of Geological and Geophysical Surveys, University of Alaska, Fairbanks Co-operative Geochronology Laboratory. Site numbers correspond to those shown on figure 10.

\begin{tabular}{|c|c|c|c|c|c|c|}
\hline $\begin{array}{l}\text { Site } \\
\text { no. }\end{array}$ & $\begin{array}{l}\text { Sample } \\
\text { number }\end{array}$ & Rock type & Mineral & Age & $\begin{array}{l}\text { Ar radio- } \\
\text { genic/ } \\
\text { Ar total }\end{array}$ & $\begin{array}{l}\text { Quad- } \\
\text { rangle }\end{array}$ \\
\hline \multicolumn{2}{|c|}{ Ruby terrane } & \multicolumn{5}{|c|}{-- Quartz monzonite and associated hornfelses of Melozitna pluton } \\
\hline 1 & 82Dn437b & Biotite granite & Biotite & $107.4 \pm 3.2$ & 0.957 & Melozitna \\
\hline 2 & 82Dn 481a & $\begin{array}{l}\text { Biotite quartz } \\
\text { monzonite }\end{array}$ & Biotite & $108.1 \pm 3.2$ & 0.613 & Melozitna \\
\hline 3 & $82 \mathrm{Dn} 493$ & $\begin{array}{l}\text { Biot ite quartz } \\
\text { monzonite }\end{array}$ & Biotite & $111.5 \pm 3.3$ & 0.736 & Melozitna \\
\hline 4 & 82Dn491B & $\begin{array}{l}\text { Hornfelsic biotite } \\
\text { amphibolite }\end{array}$ & Amphibole & $104.3 \pm 3.1$ & 0.567 & Melozitna \\
\hline \multirow[t]{2}{*}{5} & $82 \operatorname{Dn} 490 \mathrm{a}$ & $\begin{array}{l}\text { Hornfelsic biotite } \\
\text { amphibolite }\end{array}$ & Amphibole & $106.4 \pm 3.2$ & 0.663 & Melozitna \\
\hline & $82 \mathrm{Dn} 490 \mathrm{a}$ & $\begin{array}{l}\text { Hornfelsic biotite } \\
\text { amphibolite }\end{array}$ & Biotite & $109.9 \pm 3.3$ & 0.664 & Melozitna \\
\hline \multicolumn{7}{|c|}{ Ruby terrane -- Pre-Cretaceous } \\
\hline \multirow[t]{2}{*}{6} & $82 \operatorname{Dn} 424$ & $\begin{array}{l}\text { Granitic } \\
\text { or thogne iss }\end{array}$ & Biotite & $110.2 \pm 3.3$ & 0.611 & Melozitna \\
\hline & 82Dn 424 & $\begin{array}{l}\text { Gran it ic } \\
\text { or thogne iss }\end{array}$ & $\begin{array}{l}\text { White } \\
\text { mica }\end{array}$ & $119.6 \pm 3.6$ & 0.330 & Melozitna \\
\hline 7 & $81 \mathrm{Dn} 76$ & $\begin{array}{l}\text { Granitic } \\
\text { or thogne iss }\end{array}$ & Biotite & $112.6 \pm 3.4$ & $\begin{array}{l}0.847 \\
0.847\end{array}$ & Melozitna \\
\hline \multicolumn{7}{|c|}{ Nixon Fork terrane (North) -- Metamorphic } \\
\hline 8 & $81 \mathrm{Dn} 87$ & $\begin{array}{l}\beta \text {-quartz K-feld- } \\
\text { spar porphyry }\end{array}$ & $\begin{array}{l}\text { Whi te } \\
\text { mi ca }\end{array}$ & $697.0 \pm 20$ & 0.964 & Ruby \\
\hline
\end{tabular}

unpub. data, 1984) show that most of the metasedimentary rocks have Paleozoic protolith ages. The possibility that some protoliths may be as old as Precambrian cannot be ruled out, however.

The Ruby terrane is structurally overlain by allochthonous sheets of Mississippian to Jurassic oceanic crustal rocks that appear to have been emplaced in Late Jurassic or Early Cretaceous time. The oceanic rocks have locally been assigned to the Innoko, Tozitna, and Angayucham terranes (Patton, 1978; Jones and others, 1981). K-Ar metamorphic muscovite ages of $135 \mathrm{~m} . \mathrm{y}$. obtained from the Ruby terrane (Patton and others, 1984) are thought to represent a major regional metamorphic event related to overthrusting of these oceanic rocks. Both the metamorphic rocks and the oceanic rocks are intruded by granitic plutons that yield ages of about 110 m.y. (Patton and others, 1978; Patton and others, 1984).

Six new K-Ar ages from mineral separates from quartz monzonite and associated hornfels of the Melozitna pluton in the Ruby terrane (table 3, nos. 1-5) confirm the 110-m.y. cooling ages obtained previously from the Melozitna pluton. Nearby amphibolite-facies orthogneiss (table 3, nos. 6-7) yielded three $\mathrm{K}-\mathrm{Ar}$ ages of 110 to $120 \mathrm{~m} . \mathrm{y}$. U-Pb data from two samples of orthogneiss (table 4 , nos. 7 and 9) are insufficient to determine the protolith age and subsequent thermal history of the rocks, but the data do indicate that: (1) the parent magma of the aplitic orthogneiss contained a Paleozoic or Precambrian component, as evidenced by the $680-$ 
Table 4.--U-Pb isotopic ages from analyses using a mixed ${ }^{235} \mathrm{U}^{205} \mathrm{~Pb}$ spike and methods described in Krogh (1973) and Dillon and others (1979). Site numbers correspond to those shown on figure 10 .

\begin{tabular}{|c|c|c|c|c|c|c|c|}
\hline Site & Sample & Rock type & Zircon & ${ }^{206} \mathrm{~Pb}^{*}$ & ${ }^{207} \mathrm{~Pb}^{*}$ & ${ }^{207} \mathrm{~Pb}^{*}$ & Quadrangle \\
\hline no.* & number & & description & ${ }^{238_{\mathrm{U}}}$ & $235_{\mathrm{U}}$ & ${ }^{206} \mathrm{~Pb}$ & \\
\hline
\end{tabular}

Ruby terrane

$\begin{array}{ll}81 D n 76 & \text { Aplitic } \\ & \text { or thogne iss }\end{array}$

9 81Dn77 Fine-grained granit ic or thogne iss

10

$\begin{array}{cc}\text { 81Dn78 } & \begin{array}{c}\text { Slightly foliated } \\ \text { quartz porphyry } \\ \text { 81Dn78 } \\ \text { Slightly foliated } \\ \text { quartz porphyry }\end{array} \\ \text { 81Dn78 } & \begin{array}{c}\text { slightly foliated } \\ \text { quartz porphyry }\end{array} \\ \text { 81Dn81 } & \begin{array}{c}\text { Slightly foliated } \\ \text { brecciated felsic } \\ \text { volcanic }\end{array}\end{array}$

81Dn81 Slightly foliated brecciated felsic volcanic

81Dn81 Slightly foliated brecciated felsic volcanic
Clear, less than 170 mesh
$\mathrm{Clear}$, less than 230 mesh

147.8

120.5

129.1

679.0

292.0

\section{Nixon Fork terrane (South)}

Trans lucent-be ige,

388.3

263.0

447.7

765.6

Medf ra

Trans lucent -be ige, moderately magnetic

Trans lucent-be ige, magnet ic

212.8

314.3

714.6

Medfra

Trans lucent-pink, 100-230 mesh, non-magnet ic

Trans lucent-pink, 100-230 mesh, magnetic

Trans lucent -pink, 100-230 mesh, M11

$$
765.9
$$

256.1

673.0

Medf ra

783.8

835.0

Medf ra

731.3

758.7

840.

668.4

708.9

839.3

Med f ra

Nixon Fork terrane (North)

12

\begin{tabular}{|c|c|}
\hline 81Dn 85 & $\begin{array}{l}\text { Metamor phosed } \\
\text { beta quartz- } \\
\text { Kspar porphyry }\end{array}$ \\
\hline 81Dn85 & $\begin{array}{l}\text { Metamorphosed } \\
\text { beta quartz- } \\
\text { Kspar porphyry }\end{array}$ \\
\hline $81 D n 85$ & $\begin{array}{l}\text { Metamorphosed } \\
\text { beta quartz- } \\
\text { Kspar porphyry }\end{array}$ \\
\hline 81Dn85 & $\begin{array}{l}\text { Metamor phosed } \\
\text { beta quartz- } \\
\text { Kspar porphyry }\end{array}$ \\
\hline 81Dn86 & $\begin{array}{l}\text { Metamor phosed } \\
\text { beta quartz- } \\
\text { Kspar porphyry }\end{array}$ \\
\hline 81Dn 86 & $\begin{array}{l}\text { Metamor phosed } \\
\text { beta quartz- } \\
\text { Kspar porphyry }\end{array}$ \\
\hline $81 \mathrm{Dn} 86$ & $\begin{array}{l}\text { Metamor phosed } \\
\text { beta quartz- } \\
\text { Kspar porphyry }\end{array}$ \\
\hline
\end{tabular}

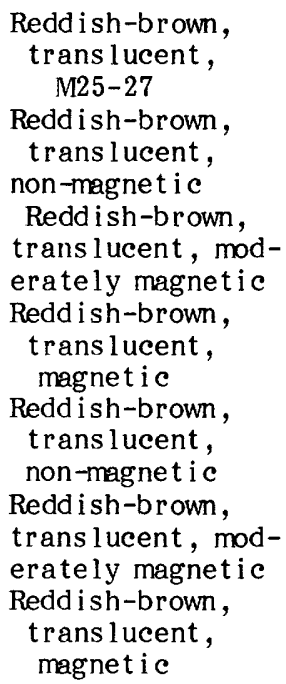

756.8

813.2

970.6

Ruby

$933.4 \quad 1006.5 \quad 1169.1 \quad$ Ruby

$831.2 \quad 917.5 \quad 1131.2 \quad$ Ruby

$692.5 \quad 790.3 \quad 1077.0 \quad$ Ruby

$\begin{array}{llll}937.6 & 999.3 & 1137.1 & \text { Ruby }\end{array}$

$\begin{array}{llll}857.6 & 932.6 & 1114.1 \quad \text { Ruby }\end{array}$

$789.4 \quad 859.2 \quad 1043.6 \quad$ Ruby m.y. ${ }^{207} \mathrm{~Pb} /{ }^{206} \mathrm{~Pb}$ age, and (2) zircon from both orthogneiss samples lost lead during Cretaceous time. Episodic lead loss probably occurred during the proposed Late Jurassic or Early Cretaceous metamorphic event and (or) later, during intrusion of the adjacent Melozitna pluton. No evidence for inherited zircon was found in these samples.

The Nixon Fork terrane, situated southeast of the Ruby terrane between the Susulatna fault and the upper Kuskokwim River, is shown as units p€m 


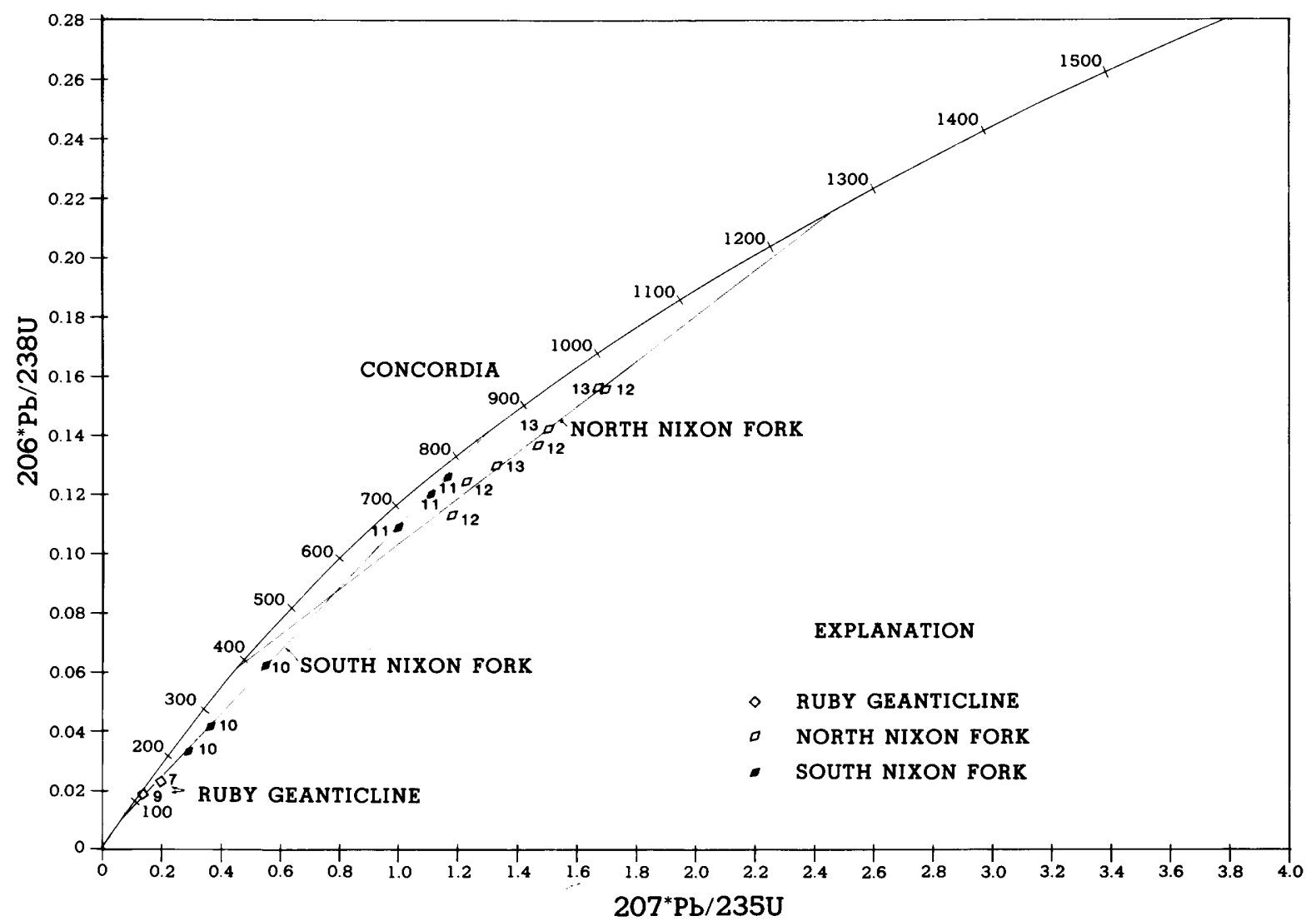

Figure 11.--Concordia diagram for zircon samples from the Ruby geanticline and Nixon Fork terrane.

and MzPzc in figure 10. It consists of metasedimentary and felsic metavolcanic and metaplutonic rocks overlain by unmetamorphosed Ordovician through Devonian shelf earbonates and Permian to middle Cretaceous terrigenous sedimentary rocks (Patton and others, 1980). Late Cretaceous and early Tertiary volcanism and plutonism were widespread throughout the terrane (Moll and others, 1981).

Six K-Ar cooling ages from the Nixon Fork metamorphic rocks, previously reported by Silberman and others (1979), range from 296 to 921 m.y. We have obtained an additional K-Ar age of 697 m.y. from this metamorphic assemblage (table 3 , no. 8). Discordant $\mathrm{U}-\mathrm{Pb}$ ages of metavolcanic rocks (table 4) define two chords (fig. 11). Six zircon fractions from the two more southerly areas (fig. 10) yield a chord with a correlation coefficient of 0.99998. The data indicate that these zircons, which come from slightly foliated quartz porphyry flows, crystallized at $850 \pm 30$ m.y. (upper intercept) and lost lead at $73 \pm 10 \mathrm{~m} . \mathrm{y}$. (lower intercept), probably due to the Late Cretaceous and early Tertiary magmatic event. Seven zircon fractions from the more northerly of the two sample areas yield a chord with a correlation coefficient of 0.99989 . Zircon recovered from a quartz-K-feldspar metaporphyry is interpreted to have been emplaced at $1,265 \pm 50 \mathrm{~m} . \mathrm{y}$. (upper intercept) and metamorphosed to greenschist facies at $390 \pm 40 \mathrm{~m} . \mathrm{y}$. (lower intercept). The early to mid-Paleozoic regional metamorphism of the northern samples apparently did not affect the southern samples. Therefore, we suspect that the Nixon Fork terrane itself may be an amalgamation of several Precambrian terranes.

Our radiometric data and the previously reported isotopic and paleontologic data indicate the following differences between the Ruby and Nixon Fork terranes:

(1) The Ruby terrane was regionally metamorphosed in Late Jurassic or Early Cretaceous time, whereas, in the Nixon Fork terrane, regional metamorphism was confined to pre-mid-Paleozoic time.

(2) Most of the metamorphic rocks in the Ruby terrane appear to have a Paleozoic protolith age, whereas most of the metamorphic rocks in the Nixon Fork terrane have a Precambrian protolith age. 


\section{REFERENCES CITED}

Brosge , W. P., Reiser, H. N., and Yeend, Warren, 1973, Reconnaissance geologic map of the Beaver Quadrangle, Alaska: U.S. Geological Survey Miscellaneous Field Studies Map MF525,1 sheet, scale 1:250,000.

Chapman, R. M.,Yeend, Warren, Brosgè, W. P., and Reiser, H. N., 1982, Reconnaissance geologic map of the Tanana Quadrangle, Alaska: U.S. Geological Survey Open-File Report 82-734, 1 sheet, scale 1:250,000.

Dillon, J. T., Pessel, G. H., Chen, J. H., and Veach, N. C., 1979, Tectonic and economic significance of Late Devonian and late Proterozoic $\mathrm{U}-\mathrm{Pb}$ zircon ages from the Brooks Range, Alaska: Alaska Division of Geological and Geophysical Surveys Geologic Report 61, p. 36-41.

Jones, D. L., Silberling, N. J., Berg, H. C., and Plafker, George, 1981, Map showing tectonostratigraphic terranes of Alaska, columnar sections, and summary descriptions of terranes: U.S. Geological Survey Open-File Report 81-792, 21 p., 2 sheets.

Krogh, T. E., 1973, A low contamination method for hydrothermal decomposition of zircon and extraction of $\mathrm{U}-\mathrm{Pb}$ for isotopic age determinations: Geochimica et Cosmochimica Acta, v. 37, p. 485-494.

Mertie, J. B., Jr., and Harrington, G. L., 1924, The Ruby-Kuskokwim region, Alaska: U.S. Geological Survey Bulletin 754, $129 \mathrm{p}$.

Moll, E. J., Silberman, M. L., and Patton, W. W., Jr., 1981, Chemistry, mineralogy, and $\mathrm{K}$-Ar ages of igneous and metamorphic rocks of the Medfra Quadrangle, Alaska: U.S. Geological Survey Open-File Report 80-811C, 2 sheets, scale $1: 250,000$.

Patton, W. W., Jr., 1978, Juxtaposed continental and oceanic-island arc terranes in the Medfra Quadrangle, west-central Alaska, in Johnson, K. M., ed., The United States Geological Survey in Alaska-Accomplishments during 1977: U.S. Geological Survey Circular 772-B, p. B38-B39.

Patton, W. W., Jr., Miller, T. P., Chapman, R. M., and Yeend, Warren, 1978, Geologic map of the Melozitna Quadrangle, Alaska: U.S. Geological Survey Miscellaneous Investigations Series Map I-1071, 1 sheet, scale $1: 250,000$.

Patton, W. W., Jr., and Moll, E. J., 1982, Structural and stratigraphic sections along a transect between the Alaska Range and Norton Sound, in Coonrad, W. L., ed., The United States Geological Survey in Alaska-Accomplishments during 1980: U.S. Geological Survey Circular 844, p. 76-78.

Patton, W. W., Jr., Moll, E. J., Dutro, J. T., Jr., Silberman, M. L., and Chapman, R. M., 1980,
Preliminary geologic map of the Medfra Quadrangle, Alaska: U.S. Geological Survey Open-File Report 80-811A, 1 sheet, scale $1: 250,000$.

Patton, W. W., Jr., Moll, E. J., Lanphere, M. A., and Jones, D. L., 1984, New age data for the Kaiyuh Mountains, in Coonrad, W. L., and Elliott, R. L., eds., The United States Geological Survey in Alaska-Accomplishments during 1981: U.S. Geological Survey Circular 868, p. 30-32.

Silberman, M. L., Moll, E. J., Patton, W. W., Jr., Chapman, R. M., and Connor, C. L., 1979, Precambrian age of metamorphic rocks from the Ruby province, Medfra and Ruby Quadrangles-Preliminary evidence from radiometric age data, in Johnson, K. M., and Williams, J. R., eds., The United States Geological Survey in Alaska-Accomplishments during 1978: U.S. Geological Survey Circular 804-B, p. B66-B68.

Reviewers: Cynthia Dusel-Bacon and R. M. Chapman

\section{SEACUFF EXPOSURES OF METAMORPHOSED CARBONATE AND SCHIST, NORTHERN SEW ARD PENINSULA}

\section{by Julie A. Dumoulin and Alison B. Till}

Extensive seacliff exposures of marble, metadolostone, and schist occur on the north shore of Seward Peninsula in the Kotzebue A-1 and A-2 Quadrangles (fig. 12). Some of the exposed units have no analogs when compared to rocks mapped to the south in the Bendeleben and Solomon Quadrangles. Others are similar to units exposed to the south, but they differ in metamorphic grade and minor, though significant, compositional characteristics. Carbonate rocks predominate from Ninemile Point westward; schists of varying composition occur with carbonate rocks to the east. The carbonate-dominated section is separated in the vicinity of Ninemile Point from the schist-dominated section by a major fault zone, thought to be the northern extension of the Kugruk fault zone of Sainsbury (1974).

The schistose rocks include those of intermediate to mafic composition, carbonaceous pelitic schist, and marble (fig. 12). The marble is intimately folded in with the intermediate to mafic schists; pelitic schist forms homogeneous outcrops. The intermediate to mafic schist is composed predominantly of actinolite, albite, epidote, and garnet. Variation in amount of each mineral type imparts a layered fabric, with layers a few centimeters to a meter in thickness. Massive medium-grained metabasite pods and lenses contain barroisite, actinolite, plagioclase, epidote, and 


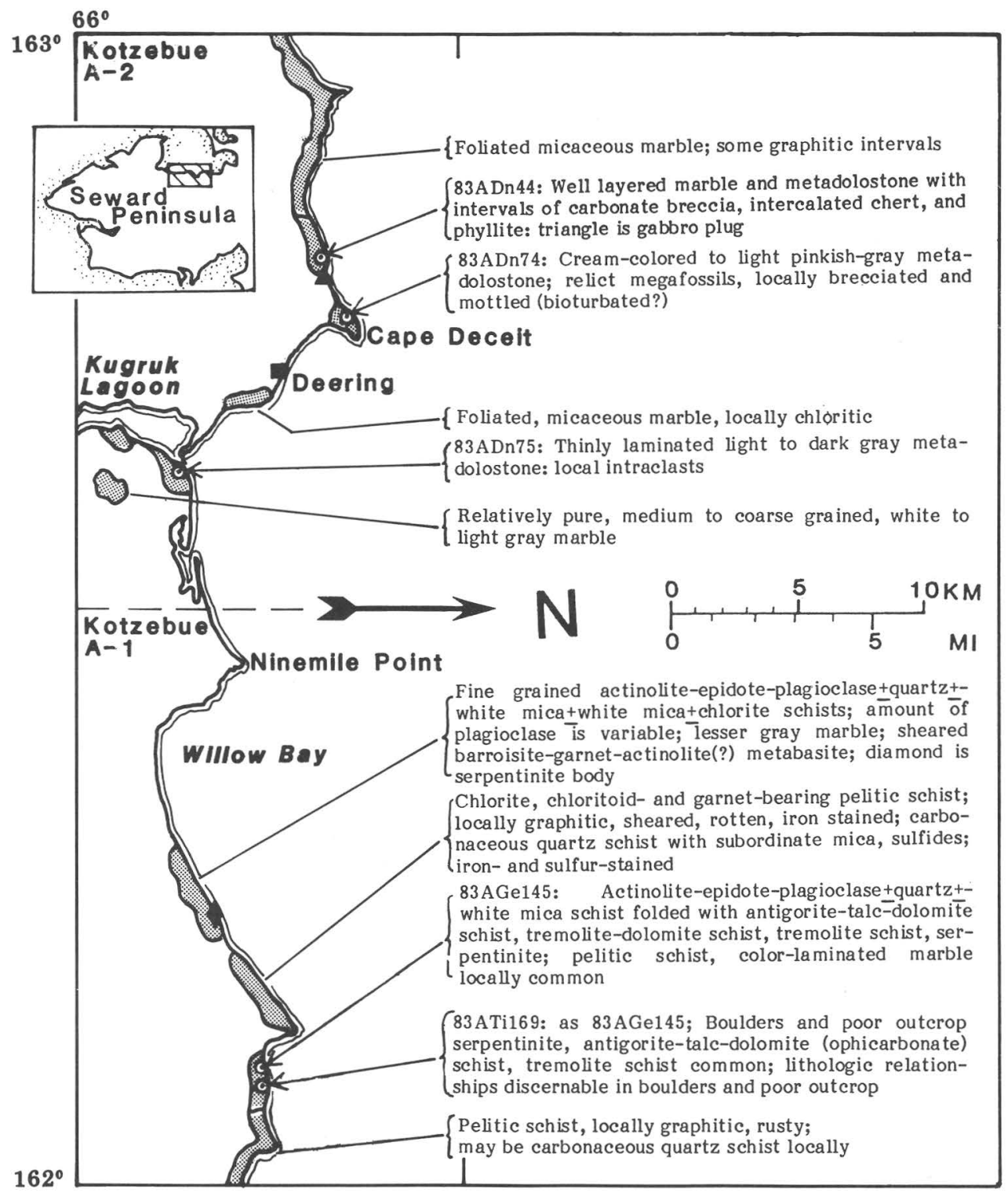

Figure 12.--Distribution of carbonate rocks and schist, Kotzebue A-1 and A-2 Quadrangles.

garnet and are conformable to the layering. The mineral assemblage indicates that these rocks are greenschist to amphibolite facies in grade. At Willow Bay, small amounts of serpentinite, ophicarbonate, and tremolite schist are folded into the unit. Metamorphic assemblages (antigoritetalc-dolomite; tremolite-dolomite; tremolite schist) represent a metamorphosed reaction zone between the carbonate and ultramafic rocks. Several exposures of serpentinite $3-10 \mathrm{~m}$ in width occur in fault contact with the schist. We have not determined whether these are part of the original sequence or if they were incorporated during a subsequent metamorphic or structural event.

Structures observed at both thin section and outcrop scale indicate that the ultramafic, mafic, and intermediate schist and marble east of the Kugruk fault zone have been locally isoclinally folded and original layering has been transposed. Isoclinal folds are commonly intrafolial. Lithologic layering may be either locally parallel or at an angle to the predominant schistosity. The greenschist- to amphibolite-facies metamorphism accompanied this deformation.

The carbonate rocks exposed on the sea cliffs west of the Kugruk fault zone consist of several dis- 


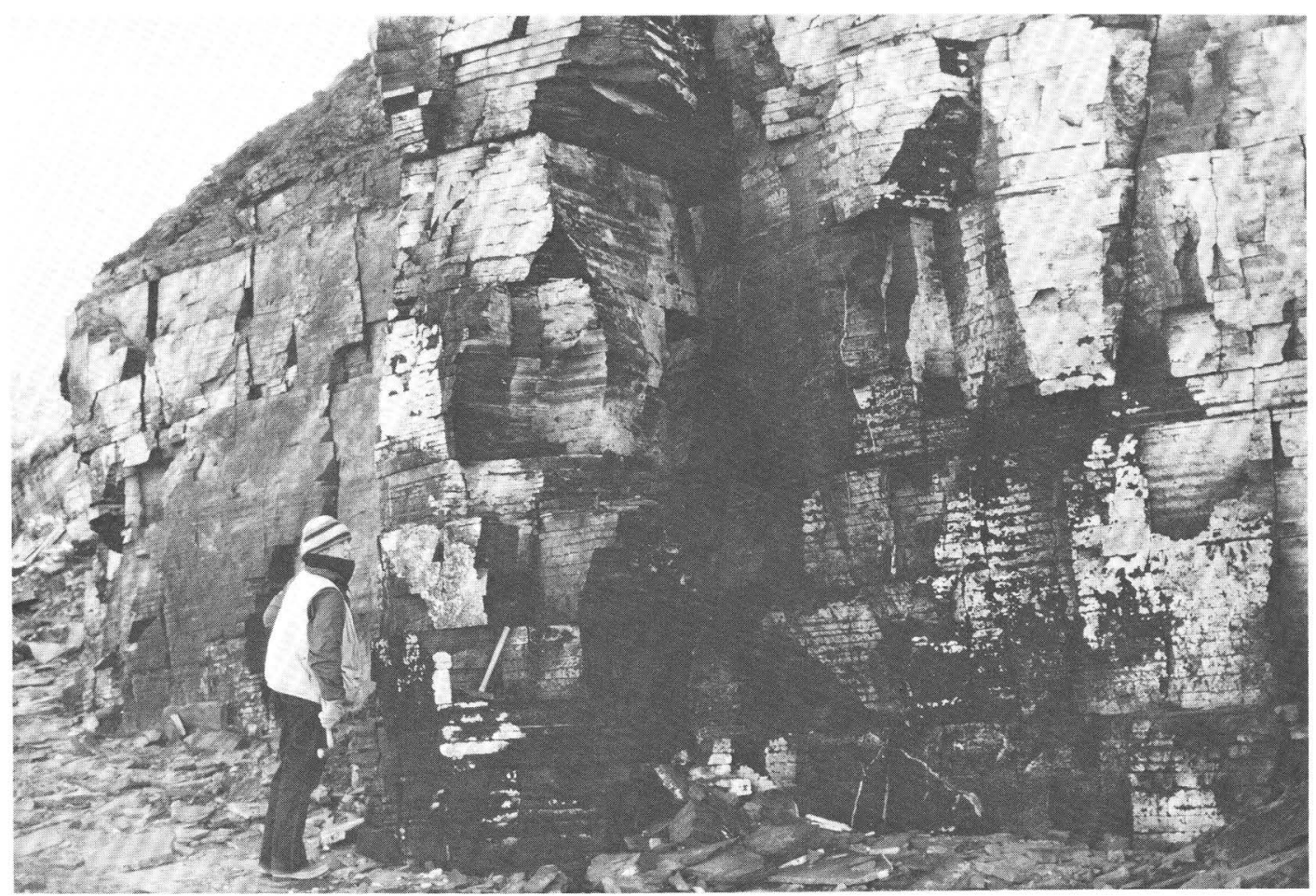

Figure 13.--Flat-lying, well-layered marble, with alternating fine and coarse crystalline layers (carbonate turbidites?).

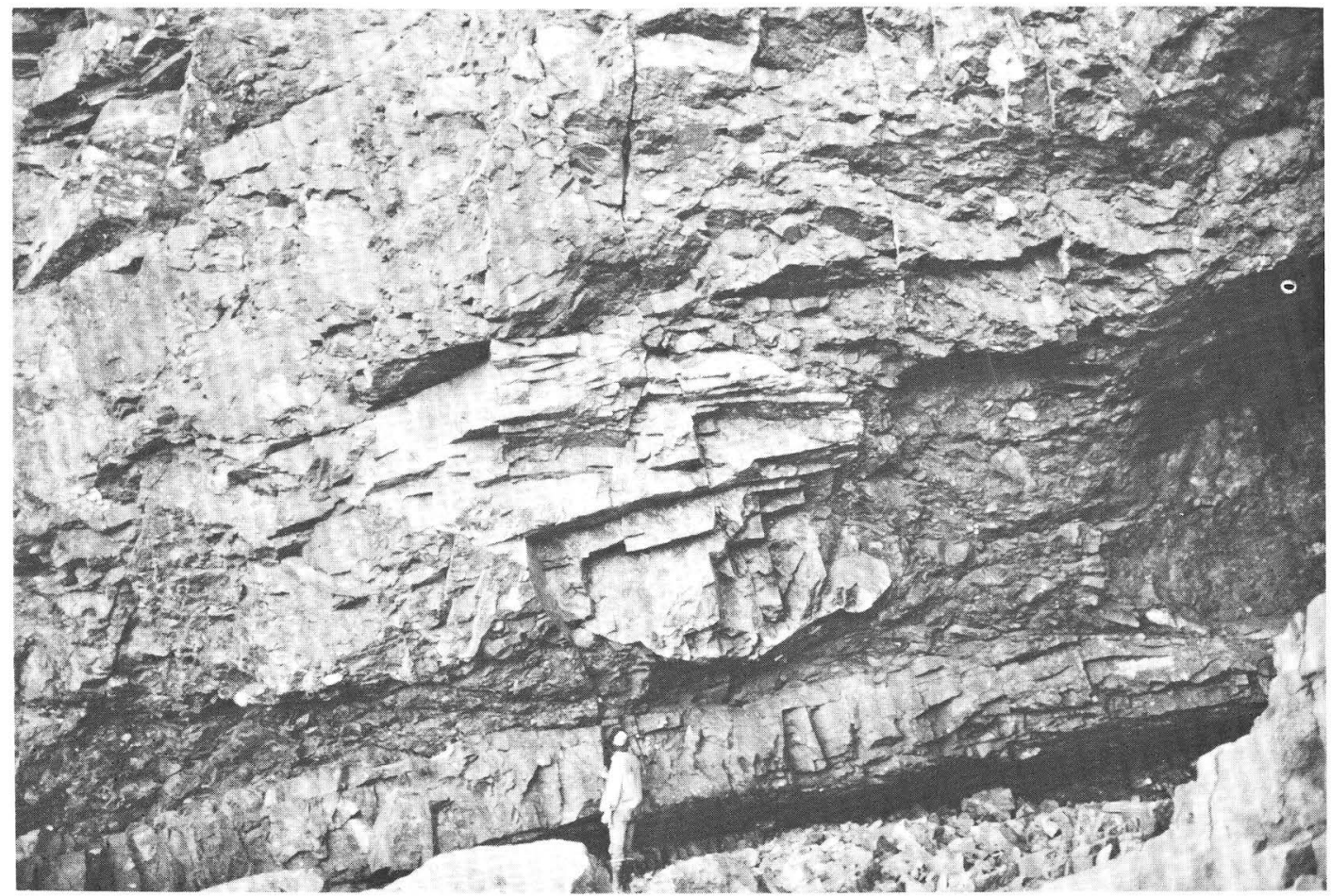

Figure 14.--Carbonate breccia (debris flow?); clasts and matrix consist mostly of marble. 
tinct lithologies (fig. 12; table 5). One kilometerlong section at locality 83ADn44 contains mostly flat-lying marble characterized by rhythmic alternation of coarser and finer crystalline layers; layer thickness ranges from 2 to $50 \mathrm{~cm}$, but typically is $5-20 \mathrm{~cm}$ (fig. 13). In the western part of the section, an interval of carbonate breccia is 15$20 \mathrm{~m}$ thick, is dominantly matrix supported, and contains both rounded and angular clasts up to $5 \mathrm{~m}$ in diameter (fig. 14). Zones as much as $1 \mathrm{~m}$ thick that are rich in carbonate intraclasts occur throughout the section. In the eastern part of the section, subordinate intercalated gray and green phyllite and black chert occur. In thin section, the chert and phyllite show sparse to abundant silica spheres and ovoids $0.1-0.2 \mathrm{~mm}$ in diameter that suggest recrystallized radiolarians and(or) sponge spicules.

The layering at locality $83 \mathrm{ADn} 44$ is apparently bedding, but the metamorphic grade (table 5), indications of flattening, and spatial association with strongly foliated and folded schist make this interpretation uncertain. The carbonate rocks are everywhere recrystallized and locally dolomitized; thin section study indicates incipient dedolomitization in some areas. Stylolites and solution collapse features also occur; breccia containing dolomite clasts in a sparry calcite matrix truncates several beds at one locality.

The rocks at $83 \mathrm{ADn} 44$ may be carbonate turbidites, and the breccia intervals suggest debris flows in form and internal structure. Complete Bouma sequences were not observed, but graded textures are common. In thin section, relict pebbly textures can be seen through the mask of recrystallization.

Carbonate rocks on this part of the Kotzebue coast were assigned a Mississippian(?) age by Hudson (1977). Sainsbury (1974) mentioned, but did not describe, fossils of probable Mississippian age near Deering. Kindle (1911) suggested a Late Silurian age for corals and lamellibranchs from Cape Deceit. We obtained conodont faunas from three localities near Deering (fig. 12, table 5); the most diagnostic age, from 83ADn44, is middle Middle Silurian. Most of the conodont collections from central Seward Peninsula are Early and earliest Middle Ordovician and late Early and Middle Devonian in age. A Late Silurian conodont fauna has been collected in the Bendeleben A-1 Quadrangle, and dolostone cobbles from several outcrops of Cretaceous(?) (Sainsbury, 1974) carbonate conglomerate in southeastern seward Peninsula have yielded Silurian ages. The conodonts and sedimentary structures in these rocks indicate deposition in warm, shallow water. The fauna at 83ADn44, in contrast, suggests deposition at depths of mid-shelf or deeper. Thus, the combination of age and depositional environment distinguish the rocks at this locality from all other carbonate rocks of central Seward Peninsula. [All age and

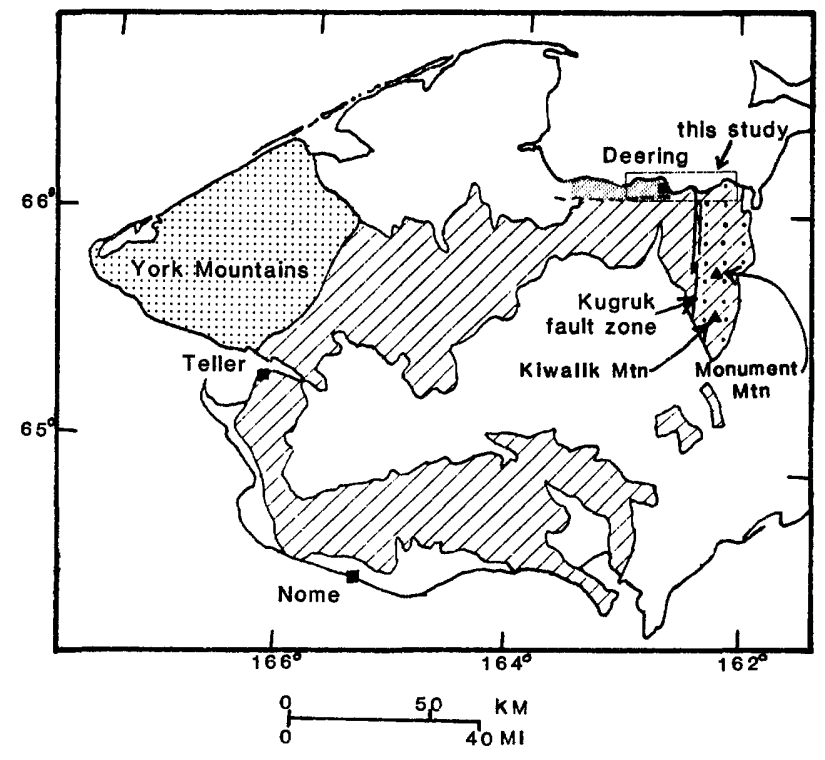

Greenschist-facies schists of northeastern Seward Peninsula

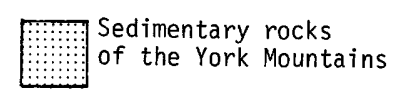
Metamorphosed carbonate
rocks of northern
Seward Peninsula Blueschist-facies schists of central

Figure 15.--Regional relationships of rock units observed in Kotzebue A-1 and A-2 Quadrangles and similar rocks in central and western Seward Peninsula.

environmental interpretations of conodonts are from A. G. Harris (written commun., 1984)].

Two small gabbroic plugs with relict ophitic textures that are partially recrystallized to greenschist-facies assemblages (actinolite, epidote, and garnet) intrude the carbonate rocks. Temperatures estimated from color alteration indices (CAI) of conodonts are consistent with this metamorphic grade.

Incorporation of rocks both east and west of Kugruk fault zone into the geologic history of the Seward Peninsula, as it has been deduced from rocks to the south, is problematical (fig. 15). Surficial deposits mantle bedrock south of the seacliff exposures. Carbonate rocks and related igneous plugs west of the Kugruk fault zone show relict primary structures more clearly than do similar units typical of central Seward Peninsula. Metamorphic grade of the mafic plugs suggests that there is a metamorphic boundary between the rocks exposed on the coast and the glaucophane-bearing rocks $14-20 \mathrm{~km}$ inland. The structural nature and orientation of the boundary are unclear. Similar gabbroic plugs have been reported south of Teller on the western peninsula (B. W. Evans, Dept. of Geological Sciences, 
Table 5.--Conodont-based age determinations from the Kotzebue Coast (CAI, color alteration index)

\begin{tabular}{|c|c|c|c|}
\hline $\begin{array}{l}\text { Sample } \\
\text { number }\end{array}$ & Li tho logy & Age & $\begin{array}{c}\text { CAI } \\
\text { Temp. }\left({ }^{\circ} \mathrm{C}\right)\end{array}$ \\
\hline 83ADn44 & $\begin{array}{l}\text { Well layered, light- to dark-gray mar- } \\
\text { ble and metadolostone, locally graded; } \\
\text { some associated intervals of carbonate } \\
\text { breccia }\end{array}$ & $\begin{array}{l}\text { Middle Wen lock } \\
\text { (middle Middle } \\
\text { Silurian) }\end{array}$ & $\begin{array}{l}5.5-7.5 \\
350-450^{\circ}\end{array}$ \\
\hline 83ADn74 & $\begin{array}{l}\text { Cream-colored to light pinkish-grey } \\
\text { metadolostone; locally mottled (bio- } \\
\text { turbated?) with relict, poorly pre- } \\
\text { served megafossils; in part, strongly } \\
\text { brecciated }\end{array}$ & $\begin{array}{l}\text { Ordovician } \\
\text { through } \\
\text { Devonian }\end{array}$ & $\stackrel{7,}{\text { about } 400^{\circ}}$ \\
\hline 83ADn75 & $\begin{array}{l}\text { Thinly laminated, light - to dark-gray } \\
\text { metadolostone with sparse intraclasts; } \\
\text { local breceiation and mottling }\end{array}$ & $\begin{array}{l}\text { Silur ian through } \\
\text { Middle Devoni an }\end{array}$ & $\begin{array}{l}5.5-6, \\
350-400^{\circ}\end{array}$ \\
\hline
\end{tabular}

Univ. of Wash., oral commun., 1982). Unmetamorphosed deep-water carbonate rocks are known from the York Mountains, but existing age data suggest that these rocks are older than the metamorphosed carbonates west of the Kugruk fault zone (Sainsbury, 1969).

Schists east of the Kugruk fault zone together with greenschist- to amphibolite-facies schists $50 \mathrm{~km}$ due south on Monument and Kiwalik Mountains can be assigned to units mapped in central Seward Peninsula on the basis of their composition and lithologic relationships. In central Seward Peninsula, however, the schists have recrystallized to blueschist facies and contain glaucophane, garnet, and epidote; ultramafic lithologies are lacking. The greenschist- to amphibolite-facies rocks may have had the same high-pressure history but recrystallized finally at higher temperatures than the glaucophane-bearing rocks. The higher temperature assemblage may be due to the block of schist in northeastern Seward Peninsula having (1) equilibrated in a zone of higher geothermal gradient or (2) been at depth longer than the blueschistfacies rocks of central Seward Peninsula.

\section{REFERENCES CITED}

Hudson, Travis, 1977 (1978), Geologic map of Seward Peninsula, Alaska: U. S. Geological Survey Open-File Report 77-796A, 1 sheet, scale $1: 1,000,000$.

Kindle, E. M., 1911, The faunal succession in the Port Clarence Limestone, Alaska: American Journal of Science, ser. 4, v. 32, p. 335-349.

Sainsbury, C. L., 1969, Geology and ore deposits of the central York Mountains, western Seward Peninsula, Alaska: U.S. Geological Survey Bulletin 1287, $101 \mathrm{p}$.
Sainsbury, C. L., 1974, Geologic map of the Bendeleben Quadrangle, Seward Peninsula; Alaska: The Mapmakers, Anchorage, Alaska, $31 \mathrm{p}$.

Reviewers: J. H. Dover and J. M. Schmidt

\section{WINDY CREEK AND CRATER CREEK FAULTS, SEW ARD PENINSULA}

\section{by Darrell S. Kaufman}

The Windy Creek and Crater Creek faults in the southern Seward Peninsula (fig. 16) show surface features indicative of recent motion. These faults were recognized during reconnaissance geologic mapping by Sainsbury and others (1972) and by Miller and others $(1971,1972)$, but no detailed delineation of fault traces or description of surface features was documented. A study of these faults was conducted during 1982 and 1983 as part of the mineral resource assessment of the Solomon and Bendeleben Quadrangles. The study was carried out in order to better understand the Quaternary tectonic history of these faults and to document their associated geomorphic features.

Modern seismicity and Holocene faulting indicate that the southern Seward Peninsula is the site of ongoing tectonic activity. In a 2-yr period from 1977 to 1978 , Biswas and others (1980) recorded approximately 300 earthquakes in the range of Richter magnitude 1.0 to 4.5 that occurred on the Seward Peninsula and adjacent continental shelf. One cluster of earthquake epicenters is aligned along the Darby Mountains and traverses the site of a magnitude 6.5 earthquake that occurred in 1950 . Another cluster is associated with the Bendeleben 


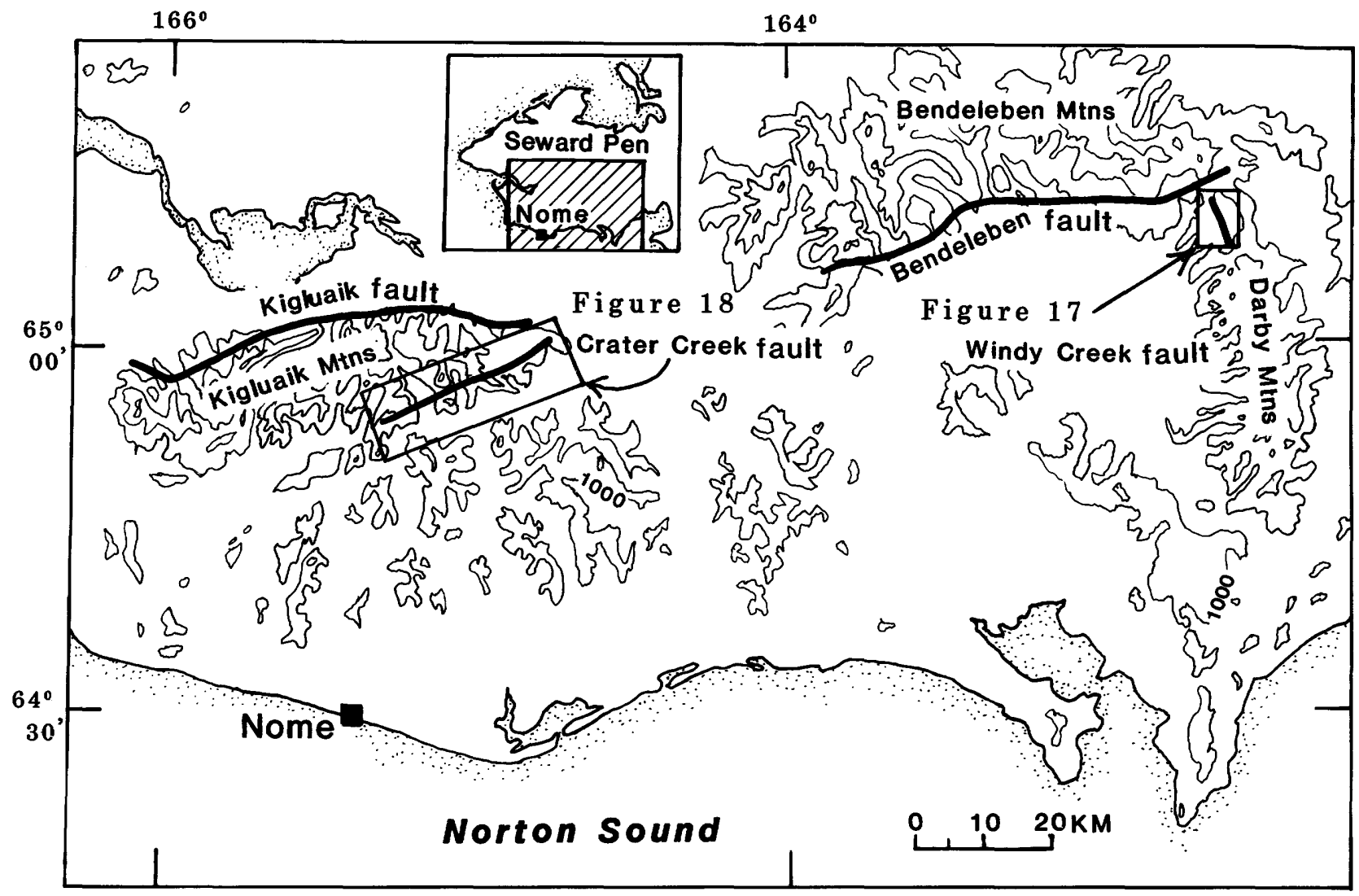

Figure 16.--Location of major mountain ranges and faults (solid bold lines) of the southern Seward Peninsula, including the Windy Creek (fig. 17) and Crater Creek (fig. 18) faults. Contour interval approximately $1,000 \mathrm{ft}(300 \mathrm{~m})$.

and northern Kigluaik range-front faults. These are the principle active faults of the Seward Peninsula; they display surface features indicative of Holocene displacement (Hudson and Plafker, 1978). The Windy Creek and Crater Creek faults are in close proximity to the Bendeleben and northern Kigluaik range-f ront faults, respectively (fig. 16).

The Windy Creek fault of the northern Darby Mountains (fig. 17) trends northwest for approximately $13 \mathrm{~km}$, forming a sharp contact between lowgrade metamorphic rocks and the plutonic rocks of the Windy Creek stock. To the west and adjacent to the central, most prominent, segment of the fault, bedrock is composed of partly hornfelsed, blueschist-facies, chlorite-bearing, pelitic schist with a dominant north-dipping foliation. East of this part of the fault, the Windy Creek stock is composed chiefly of hornblende monzogranite (Joseph Briskey, U.S. Geological Survey, written commun., 1983) of middle Cretaceous age (Miller and others, 1972). Extending southward $4 \mathrm{~km}$ from Windy Creek to an unnamed drainage, the fault is marked by a steeply sloping $\left(25^{\circ}-35^{\circ}\right)$, vegetated scarp that is consistently down-dropped to the west. The scarp is $2-7 \mathrm{~m}$ high and exposes frostrived bedrock and solifluction deposits. Slumping is common along the fault trace, forming hummocky topography on the down-thrown side; water seeps occur at the toes of the slumps. The northern and southern segments of the Windy Creek fault traverse benches and saddles in a mixed bedrock assemblage of metamorphic carbonate and metasedimentary rocks. Extremities of the fault trace are concealed beneath thick deposits of Quaternary colluvium.

The Crater Creek fault (fig. 18) trends eastnortheast for approximately $31 \mathrm{~km}$, forming an abrupt boundary between the high-grade metamorphic rocks of the rugged Kigluaik Mountains to the north and the low-grade metamorphic rocks of the low, rounded, colluvium-covered hills to the south. To the north, bedrock is composed primarily of staurolite and higher grade metasedimentary rocks; to the south, bedrock includes a mixed assemblage of blueschist-facies, chlorite-bearing, pelitic schists and carbonate rocks. Metamorphic foliation varies, but is generally parallel to the strike of the fault on the north and is at a high 
angle to it on the south. The fault is down-dropped to the south, and several stream offsets suggest a left-lateral strike-slip component ranging from 200 to $400 \mathrm{~m}$. Splays are abundant, occurring primarily in graphite-bearing schists. The fault trace is marked by prominent surface features. The eastern segment, from Crater Creek to the east fork of Homestake Creek, forms a steep $\left(20^{\circ}-30^{\circ}\right)$, vegetated scarp as much as $4 \mathrm{~m}$ high on which active gullying is taking place. Cracks in tundra surfaces, springs, and exposed fault breccia are common features. The exceptionally large alluvial fans at the mouths of Big Creek and both forks of Homestake Creek may be related to uplift along this segment of the fault. These fans are built out onto a valley last occupied by ice during the Salmon Lake glaciation, which Hopkins and others (1983) show to be of early Wisconsin age. West of Big Creek, the fault offsets solifluction-reworked lateral moraines occurring high on the east side of the the Crater Creek glacial trough. The moraines are assigned to the Salmon Lake glaciation and provide a maximum age for the onset of the most recent fault movement. At Tumit Creek, dip-slip movement offsets the wall and ridge of a regraded middle(?) Pleistocene glacial cirque. West of Tumit Creek, the fault trace is marked by notches and benches in bedrock; at its western extremity, it breaks into fault splinters marked by less prominent traces and is buried beneath colluvium.

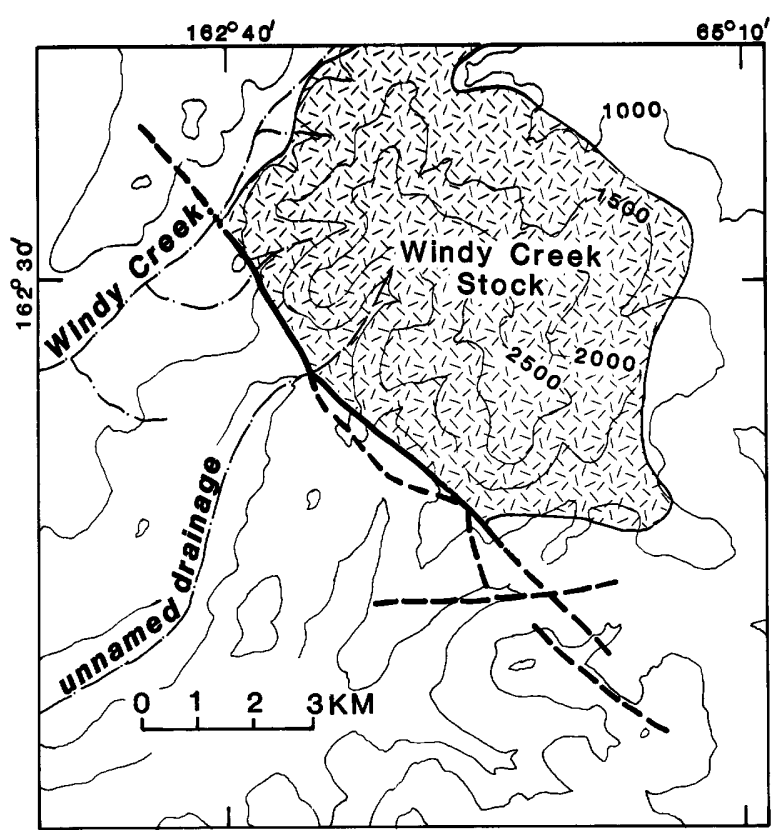

Figure 17.--Location of Windy Creek fault; solid bold line where fault trace is well defined; dashed where inferred. Delineation of Windy Creek stock after Miller and others (1971). Contour interval is $\mathbf{5 0 0} \mathrm{ft}$.
The Windy Creek and Crater Creek faults are major faults of the southern Seward Peninsula. Despite the presence of features indicative of recent movement, nowhere can the absolute age of the most recent displacement be determined. The proximity of these faults to other active faults and sites of modern seismicity suggest that they are probably part of the major active Quaternary fault system of the southern Seward Peninsula.

\section{REFERENCES CITED}

Biswas, N. N., Gedney, L, and Agnew, J., 1980, Seismicity of western Alaska: Bulletin of the Seismological Society of America, v. 70, no. 3, p. 873-883.

Hopkins, D. M., Pratt, Richard, Nelson, R. E., and Powell, C. L., 1983, Glacial sequence, southwestern Seward Peninsula, in Thorson, R. M., and Hamilton, T. D., eds., Glaciation in Alaska: Alaska Quaternary Center Occasional Paper No. 2, University of Alaska, p. 45-50.

Hudson, T. L., and Plafker, George, 1978, Kigluaik and Bendeleben faults, Seward Peninsula, in Johnson, K. M., ed., The United States Geological Survey in Alaska-Accomplishments during 1977: U.S. Geological Survey Circular 772-B, p. B47-B50.

Miller, T. P., Elliot, R. L., Grybeck, D. H., and Hudson, T. L., 1971, Results of geochemical sampling in the northern Darby Mountains, Seward Peninsula, Alaska: U.S. Geological Survey open-file report, $12 \mathrm{p}$.

Miller, T. P., Grybeck, D. H., Elliot, R. L., and Hudson, T. L., 1972, Preliminary geologic map of the eastern Solomon and southeastern Bendeleben Quadrangles, eastern Seward Peninsula, Alaska: U.S. Geological Survey open-file report, $11 \mathrm{p}$.

Sainsbury, C. L., Hudson, T. L., Ewing, Rodney, and Marsh, W. R., 1972, Reconnaissance geologic map of the west half of the Solomon Quadrangle, Alaska: U.S. Geological Survey open-file report, $10 \mathrm{p}$.

Reviewers: George Plafker and A. B. Till

\section{METAMORPHIC ROCKS IN THE WESTERN IDITAROD QUADRANGLE, WEST-CENTRAL ALASKA}

\section{by Marti L. Miller and Thomas K. Bundtzen}

During a reconnaissance visit to the Iditarod Quadrangle in August 1983, metamorphic rocks that crop out near VABM Idono (fig. 19) were examined. These rocks were first described by Gemuts and others (1983) as the Idono sequence, consisting of augen gneiss and amphibolite. Gemuts and others (1983) included the Idono sequence with Precam- 


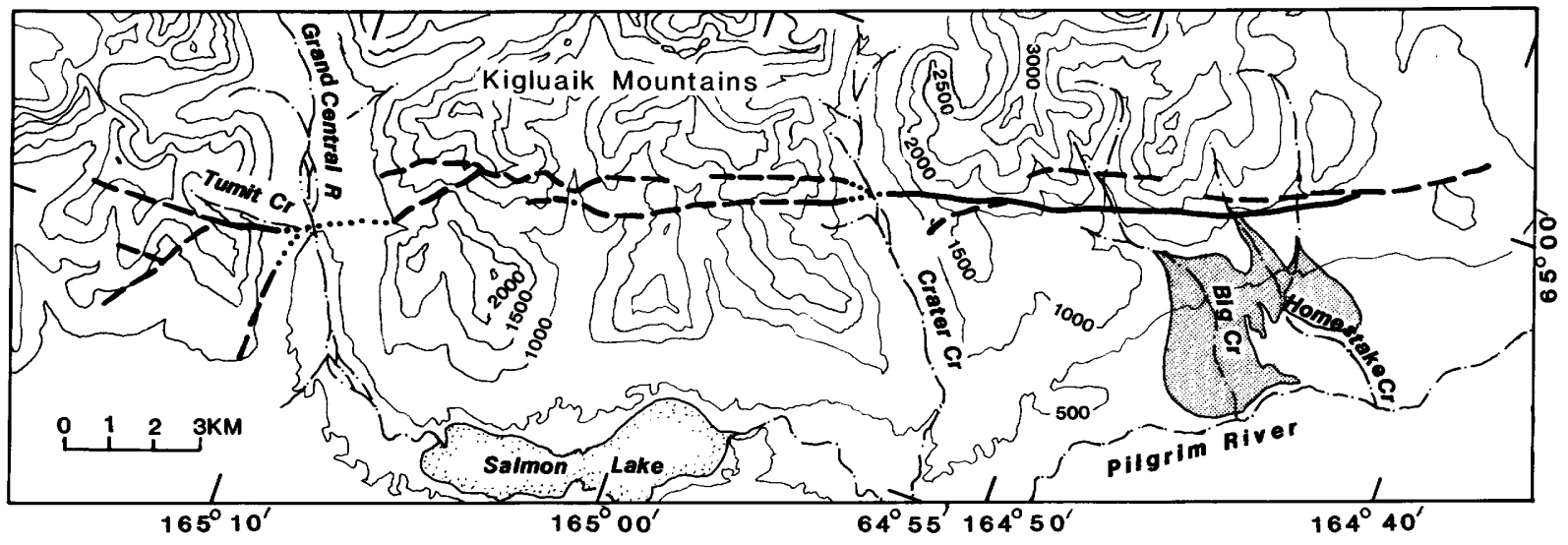

Figure 18.--Location of Crater Creek fault; solid bold line where fault trace is well defined; dashed where inferred. The late Pleistocene alluvial fans of Big and Homestake Creeks are shaded. Contour interval is $\mathbf{5 0 0} \mathrm{ft}$.

brian and Paleozoic metamorphic rocks of the Ruby geanticline (Patton and others, 1977). The three closest exposures of possibly correlative rocks are: (1) the Kanektok metamorphic complex (Hoare and Coonrad, 1979), (2) the metamorphic rocks of the Ruby-Medfra area, and (3) the metamorphic rocks of the Kaiyuh Hills (fig. 19). This study suggests that the metamorphic rocks of the Idono sequence are most closely related to those of the Kaiyuh Hills.

We did not examine or map the full extent of the metamorphic rocks during our brief reconna issance work; coverage will be extended in 1984 . This progress report presents data on a few samples collected near VABM Idono, where outcrops consist of well-foliated amphibolite and subordinate pelitic schist with minor quartzite rubble. Based on petrographic study of six samples, the rocks present in outcrop are: (1) sphene-epidote-calcic oligoclasequartz-hornblende amphibolite; (2) apatite-plagioclase-biotite-muscovite-quartz schist, and (3) sodic oligoclase porphyroblastic biotite-muscovite-quartz schist. (Feldspar compositions were determined optically using the A-normal technique.) The presence of hornblende and calcic oligoclase in the amphibolite indicates lowest amphibolite facies of regional metamorphism close to the greenschist facies boundary (Winkler, 1976). $\mathrm{K}-\mathrm{Ar}$ ages obtained from rocks at VABM Idono are shown in table 6 . They range from 126 to $134 \mathrm{~m}$.y.

The Kanektok metamorphic complex (referred to as the Kilbuck tectonostratigraphic terrane by Turner and others, 1983) crops out about $275 \mathrm{~km}$ southwest of the Idono sequence (fig. 19). It consists of quartz diorite, granodiorite gneiss, orthoclase gneiss, garnetiferous amphibolite, marble, and quartz-mica schist of upper greenschist to lower amphibolite facies (Hoare and Coonrad, 1979). U-Th- $\mathrm{Pb}$ analyses by Turner and others (1983) indicate that the granite orthogneiss protolith from the Kanektok metamorphic complex originally crystallized 2.05 b.y. ago and the sedimentary, volcanic, and igneous protoliths underwent high-grade metamorphism 1.77 b.y. ago. Fifty $\mathrm{K}-\mathrm{Ar}$ age determinations on biotite and hornblende range from $125 \mathrm{~m} . \mathrm{y}$. to $2.5 \mathrm{~b} . \mathrm{y}$. (Hoare and Coonrad, 1979). These $\mathrm{K}$-Ar mineral ages have been partially to totally reset by a late Mesozoic thermal event (Turner and others, 1983).

A variety of greenschist rocks including phyllite, pelitic schist, calcareous schist, marble, metavolcanic rocks, and foliated plutonic rocks crops out over a large area in the Ruby and Medfra Quadrangles, approximately $175 \mathrm{~km}$ northeast of the Idono sequence (fig. 19; Silberman and others, 1979; Chapman and others, 1982). Stratigraphic evidence indicates that these meta morphic rocks are at least pre-Permian and probably pre-Ordovician in age (Patton and Dutro, 1979). K-Ar ages on hornblende and mica from the Ruby and Medfra Quadrangle samples range from 274 to 921 m.y. (Silberman and others, 1979; Moll and others, 1981); the K-Ar ages are considered minimum ages. Although the age of the protolith is uncertain, two of the mineral ages support the pre-Ordovician age suggested by stratigraphy. On the basis of isochron analyses, Moll and others (1981) suggested that resetting may have occurred in the middle Permian. The Late Cretaceous and early Tertiary igneous activity of the area has apparently not significantly affected the $\mathrm{K}-\mathrm{Ar}$ ages of these metamorphic rocks, but it did cause $\mathrm{Pb}$ loss in zircon (Dillon and others, this volume, p. 13-18).

Metamorphic rocks of the Kaiyuh Hills crop out approximately $120 \mathrm{~km}$ north of the Idono sequence, making them the closest of the possibly correlative rocks. They consist mainly of pelitic schist, quartzite, and lesser carbonate and metavolcanic rocks of greenschist- to amphibolite-facies and, locally, blueschist-facies metamorphism 


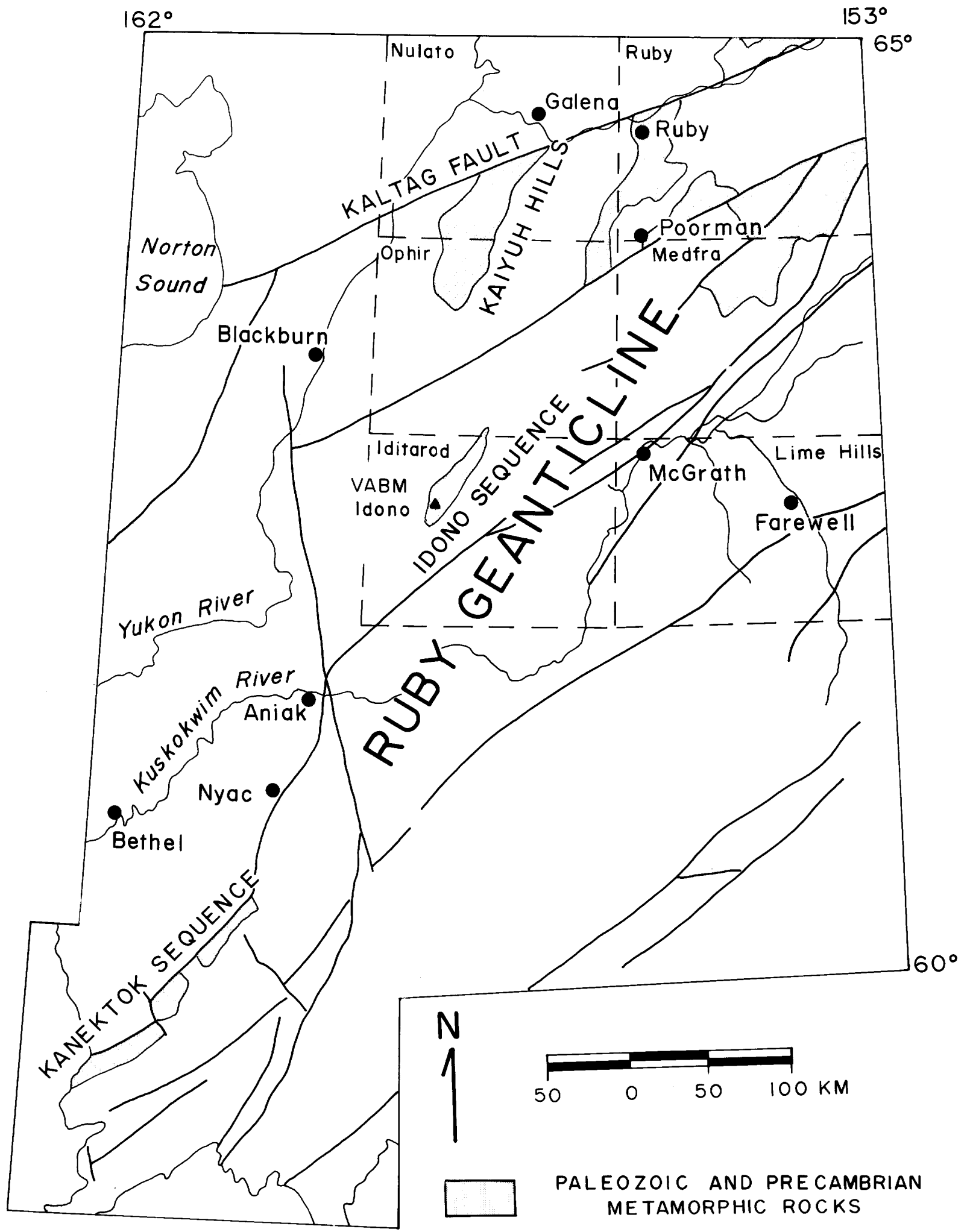

Figure 19.--Location of Paleozoic and Precambrian metamorphic rocks of west-central and southwestern Alaska. From Gemuts and others (1983; fig. 2, p. 70). 
Table 6.--Potassium-argon age determinations from rocks near VABM Idono $\mathrm{r}$, radiogenic; $\lambda$, standard deviation; $\overline{\mathrm{x}}$, mean; $\mathrm{t}$, total;

$$
\lambda_{\mathrm{e}}+\lambda_{\mathrm{e}}{ }^{\prime}=0.581 \times 10^{-10} \mathrm{yr}^{-1} ; \lambda_{\mathrm{B}}=4.962 \times 10^{-10} \mathrm{yr}^{-1} ;{ }^{40} \mathrm{~K} / \mathrm{K}_{\mathrm{t}}=1.167 \times 10^{-4} \mathrm{~mol} / \mathrm{mol} \text {. }
$$

Analyses by J. D. Blum, Alaska Division of Geological and Geophysical Surveys --University of Alaska Cooperative Geochronology Laboratory, Fairbanks, Alaska.

\begin{tabular}{|c|c|c|c|c|c|c|c|c|}
\hline $\begin{array}{l}\text { Field no. } \\
\text { (Lab no.) }\end{array}$ & $\begin{array}{l}\text { Rock } \\
\text { type }\end{array}$ & $\begin{array}{c}\text { Mi neral } \\
\text { dated }\end{array}$ & $\begin{array}{l}\mathrm{K}_{2} 0 \\
\text { (wt \%) }\end{array}$ & $\begin{array}{l}\text { Sample } \\
\text { wt (g) }\end{array}$ & $\begin{array}{l}{ }^{40}{ }_{\mathrm{Ar}} \\
\text { moles } / \mathrm{g} \\
\left(\times 10^{11}\right)\end{array}$ & $\frac{{ }^{40} \mathrm{Ar}_{\mathrm{r}}}{{ }^{40}{ }_{\mathrm{K}}}$ & $\frac{{ }^{40} \mathrm{Ar}_{\mathrm{r}}}{{ }^{40} \mathrm{Ar}_{\mathrm{t}}}$ & $\begin{array}{l}\text { Age } \pm 1 \\
(\mathrm{~m} . \mathrm{y} .)\end{array}$ \\
\hline $\begin{array}{l}83 \mathrm{Bt} 349-1 \\
(84127)\end{array}$ & $\begin{array}{l}\text { Biotite } \\
\text { muscovite } \\
\text { schist }\end{array}$ & Biotite & $\begin{array}{r}9.460 \\
9.447 \\
\bar{x}=9.454\end{array}$ & 0.0709 & 186.7 & 7.97 & 0.823 & $132.2 \pm 4.0$ \\
\hline $\begin{array}{l}\text { 83BT349-1 } \\
(84128)\end{array}$ & $\begin{array}{l}\text { Biot ite } \\
\text { muscovite } \\
\text { schist }\end{array}$ & White mica & $\begin{array}{r}10.078 \\
10.124 \\
10.118 \\
\bar{x}=10.107\end{array}$ & 0.0737 & 202.6 & 8.09 & 0.769 & $134.2 \pm 4.0$ \\
\hline $\begin{array}{l}\text { 83BT349-2 } \\
(84118)\end{array}$ & $\begin{array}{l}\text { Amphibo- } \\
\text { I i te }\end{array}$ & Hornblende & $\bar{x}=\begin{array}{r}0.660 \\
0.660 \\
660\end{array}$ & 1.0256 & 12.4 & 7.57 & 0.881 & $125.8 \pm 3.8$ \\
\hline
\end{tabular}

(Gemuts and others, 1983). Mineral separates of these rocks yield K-Ar ages of about 135 m.y. (W.W. Patton, Jr., oral commun., 1984). This indicates that if the Kaiyuh Hills and Ruby-Medfra metamorphic suites are related, the Kaiyuh Hills suite has undergone a Mesozoic metamorphic event that did not affect the Ruby-Medfra rocks.

The Idono sequence may be related to all the Precambrian and Paleozoic metamorphic rocks shown in figure 19. However, the similarity of $\mathrm{K}-\mathrm{Ar}$ ages suggests that rocks of the Idono sequence are most closely related to those of the Kaiyuh Hills. Further investigations during 1984 may refine this relation.

\section{REFERENCES CITED}

Chapman, R. M., Patton, W. W., Jr., and Moll, E. J., 1982, Preliminary summary of the geology in the eastern part of Ophir Quadrangle, in Coonrad, W. L., ed., The United States Geological Survey in Alaska - Accomplishments during 1980: U.S. Geological Survey Circular 844, p. 70-73.

Gemuts, I., Puchner, C. C., and Steffel, C. I., 1983, Regional geology and tectonic history of western Alaska, in Proceedings of the 1982 Alaska Geological Society Symposium on western Alaska geology and resource potential: Journal of the Alaska Geological Society, v. 3, p. 67-85.
Hoare, J. M., and Coonrad, W. L., 1979, The Kanektok metamorphic complex, a rootless belt of Precambrian rocks in southwestern Alaska, in Johnson, K. M., and Williams, J. R., eds., The United States Geological Survey in Alaska-Accomplishments during 1978: U.S. Geological Survey Circular 804-B, p. B72-B74.

Moll, E. J., Silberman, M. L., and Patton, W. W., Jr., 1981, Chemistry, mineralogy, and $\mathrm{K}-\mathrm{Ar}$ ages of igneous and metamorphic rocks of the Medfra Quadrangle, Alaska: U.S. Geological Survey Open File Report 80-811C, 19 p., 2 sheets.

Patton, W. W., Jr., and Dutro, J. T., Jr., 1979, Age of the metamorphic complex in the northern Kuskokwim Mountains, west-central Alaska, in Johnson, K. M., and Williams, J. R., eds., The United States Geological Survey in AlaskaAccomplishments during 1978: U.S. Geological Survey Circular 804-B, p. B61-B63.

Patton, W. W., Jr., Tailleur, I. L., Brosge, W. P., and Lanphere, M. A., 1977, Preliminary report on the ophiolites of northern and western Alaska, in Coleman, R. G., and Irwin, W. P., eds., North American ophiolites: Oregon Department of Geology and Mineral Industries Bulletin 95, p. 51-57.

Silberman, M. L., Moll, E. J., Patton, W. W., Jr., Chapman, R. M., and Connor, C. L., 1979, Precambrian age of metamorphic rocks from the Ruby province, Medfra and Ruby Quadrangles - Preliminary evidence from radiometric age 
data, in Johnson, K. M., and Williams, J. R., eds., The United States Geological Survey in Alaska-Accomplishments during 1978: U.S. Geological Survey Circular 804B, p. B66-B68.

Turner, D. L., Forbes, R. B., Aleinikoff, J. N., Hedge, C. E., and McDougal, Ian, 1983, Geochronology of the Kilbuck terrane of southwestern Alaska (abs.): Geological Society of America, 79th annual meeting, Cordilleran Section, Salt Lake City, Utah, May 2-4, 1983, Abstracts with Programs, v. 15, no. 5, p. 407.

Winkler, H. G. F., 1976, Petrogenesis of metamorphic rocks, (4th ed.): New York, SpringerVerlag, 334 p.

Reviewers: W. W. Patton, Jr., and J. H. Dover

\section{EAST-CENTRAL ALASKA}

(Figure 20 shows study areas described.)

\section{STUDIES OF GOLD IN THE CHANDALAR AND KOYUKUK DISTRICTS, WISEM AN AND BETTLES QUADRANGLES- A PROGRESS REPORT}

\section{by John C. Antweiler, Richard B. Tripp, John B. CathraIl, and Elwin L. Mosier}

More than 95 percent of gold production in permafrost regions in Alaska has come from placers. Lode sources of gold for these placer deposits are mostly undiscovered. Our studies have attempted to identify the source of placer gold by examination of the geologic setting of each deposit, a mineralogical analysis of the heavy-mineral concentrate, and compositional analyses of gold obtained from the placers and the few known lodes. Laboratory and field investigations included an examination of the occurrence and geochemistry of gold in minerals, rocks, soil, water, and humus, as well as the role of vegetation, bacteria and microfungi in solution, transport, and deposition of gold.

Nearly all gold production in the Chandalar and Koyukuk districts has come from Quaternary placer deposits that occur in a belt about $160 \mathrm{~km}$ in length (fig. 20). Devonian and Mississippian metasedimentary rocks comprise bedrock at most localities (Brosgè and Reiser, 1964, 1971; Dillon, 1982), but conglomerate of Jurassic age occurs at Tramway Bar in the Wiseman Quadrangle (Brosge and Reiser, 1971). The metasedimentary rocks are composed of conglomerate, sandstone, siltstone, shale, and recrystallized limestone that are interbedded with and intruded by coeval mafic and felsic volcanic and plutonic rocks (Dillon, 1982). Three or more episodes of metamorphism and multiple episodes of faulting (including some thrust faulting) complicate the geology (Dillon, 1982). Known goldbearing veins postdate the latest Cretaceous metamorphism (Dillon, 1982).

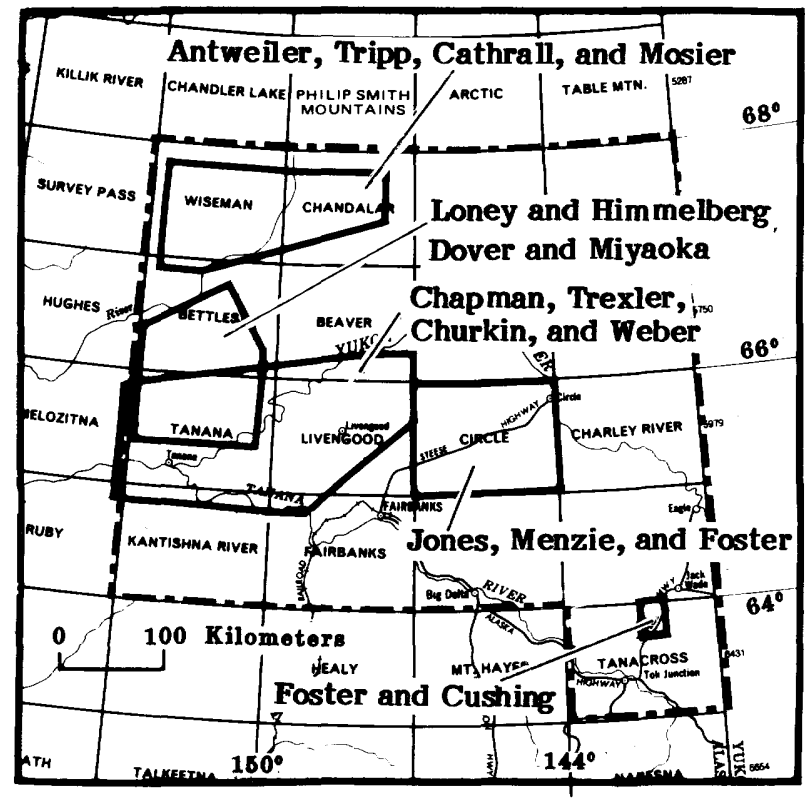

Figure 20.--Areas in east-central Alaska discussed in this circular. Outlines define the areas described by the indicated authors.

Field studies of gold deposits were focused on gold mines and prospects in the Chandalar and Koyukuk districts. Gold samples and associated heavy-mineral concentrates from active placer mines were donated by miners in the Chandalar, Wiseman, and Bettles Quadrangles. Samples of rock, soil, humus, and groundwater were also collected near several mines.

Typical concentrate minerals include quartz, amphibole, pyroxene, magnetite, epidote, hematite, zircon, and sphene. Minerals of economic interest (in addition to gold) in the concentrates include arsenopyrite, pyrite, chalcopyrite, galena, cinnabar, stibnite, scheelite, barite, and rutile. Minute blebs of gold are commonly attached to arsenopyrite and occur in stibnite. Pyrite, although common near several placer mines, is usually barren of gold and evidently is not indicative of gold mineralization. Some nuggets (i.e., gold grains heavier than $70 \mathrm{mg}$ ) contain inclusions of quartz, stibnite, arsenopyrite, galena, and pyrite. Scheelite, though present in more than half the mineral concentrates, does not seem to be present as inclusions in gold grains or attached to them. Cinnabar occurs in several placers in the Koyukuk district but not in concentrates from the Chandalar district, with the exception of the Eight-Mile Creek placer (Joesting, 1943, p. 18).

Lode sources have not been found for the majority of placer deposits in the Koyukuk or Chandalar districts. Heavy minerals associated with known lode gold occurrences in the districts are rich in sulfides. Stibnite-gold-quartz veins occur at several localities near Wiseman in the 
Koyukuk district and arsenopyrite, galena, and scheelite accompany lode gold in the Chandalar district.

Nearly 500 emission spectrographic analyses using a special technique described by Mosier (1975) were made of gold from about 50 mines and prospects in the Chandalar and Koyukuk districts. Gold of unusually high fineness (up to 980 fine) occurs in the Koyukuk district, but its signature (proportions of gold, silver, and copper, and content of trace elements) does not fit the signature of gold of high fineness from deposits elsewhere (Antweiler and Campbell, 1982). Compositional analyses of various size fractions of gold have been made on samples from some of the placers. The larger size fraction (+35 mesh) from many deposits contains smaller amounts of silver, copper, and trace elements than did the smaller size fraction ( -35 mesh). In the larger size fractions, higher purity gold may have resulted from precipitation of dissolved gold on the exterior of gold grains. On the other hand, in other similar deposits elsewhere, small-particle gold was of higher purity, suggesting that silver and trace elements were removed during transport from the lode to a placer deposit.

Groundwater collected upstream from some placer deposits contained small quantities of gold. Typically, the content of gold ranged from less than 1 to 20 parts per trillion (ppt). Water percolating through a sulfide-rich zone in the Mikado lode in the Chandalar district contained 26 ppt gold.

Schist, igneous rock, "bull quartz," quartz veins, humus, and soil below tundra roots and over permanently frozen ground near gold mines also contained small amounts of gold. Additional data must be acquired to determine whether small amounts of gold in country rock, soil, and surroundings can be the source of gold in placer deposits or if lodes with nugget-sized masses of gold are required. Studies in progress show that certain natural processes can dissolve gold, whereas others precipitate gold from solution. Humic and fulvic acids abound between tundra roots and permanently frozen ground, particularly in swampy areas. The $\mathrm{pH}$ of swamp waters in the Chandalar and Koyukuk districts in the summer ranged from 4.0 to 5.9. Laboratory experiments show that both humic and fulvic acid are capable of dissolving several hundred parts per billion ( $\mathrm{ppb}$ ) gold; for example, a fulvic acid solution of pH 4.0 can dissolve $100 \mathrm{ppb}$ (wt/vol) gold (W. L. Campbell, U.S. Geological Survey, written commun., June 15,1984$)$. In other laboratory experiments, bacterial spores served as nuclei for the growth of crystalline gold polyhedra similar to small crystalline gold nuggets found in some placer deposits (Watterson and others, 1983). It is well documented that some bacteria and microfungi can dissolve gold. In a few hours, a microfungus (Penicillium sp.) penetrated gold foil on Czapec-Dox solution agar (Watterson and others, this volume, p.1-4).

\section{REFERENCES CITED}

Antweiler, J. C., and Campbell, W. L., 1982, Gold in exploration geochemistry, in Levinson, A. L., ed., Precious metals in the northern Cordillera: Calgary, Association of Exploration Geochemists, p. 33-44.

Brosge, W. P., and Reiser, H. N., 1964, Geologic map and section of the Chandalar Quadrangle, Alaska: U.S. Geological Survey Miscellaneous Geologic Investigations Map I-375, 1 sheet, scale 1:250,000.

Brosge, W. P., and Reiser, H. N., 1971, Preliminary bedrock geologic map of the Wiseman and Survey Pass quadrangles, Alaska: U.S. Geological Survey Open-File Report 71-479, 1 sheet, scale $1: 250,000$.

Dillon, J. T., 1982, Source of lode- and placer-gold deposits of the Chandalar and Upper Koyukuk Districts, Alaska: Alaska Division of Geological and Geophysical Surveys Open-File Report 158,22 p.

Joesting, H. R., 1943, Strategic mineral occurrences in interior Alaska: Alaska Department of Mines Supplement Pamphlet 2, 28 p.

Mosier, E. L., 1975, Use of emission spectroscopy for the semiquantitative analysis of trace elements and silver in native gold, in F. N. Ward, ed., New and refined methods of trace analysis useful in geochemical exploration: U.S. Geological Survey Bulletin 1408, p. 97-105.

Watterson, J. R., Antweiler, J. C., and Campbell, W. L., 1983, Bug nuggets: International Symposium on Environmental Biogeochemistry, 6th, Santa Fe, NM, October 10-14, 1983, Programs and Abstracts , p. 24.

Reviewers: R. J. Goldf arb and Theodore Botinelly

\section{NEW CONCEPTS OF THE MESOZOIC FLYSCH BELT IN EAST-CENTRAL ALASKA}

\section{by Robert M. Chapman, James H. Trexler, Jr., Michael Churkin, Jr, and Florence R. Weber}

A thick Mesozoic flysch unit forms a broad belt between Victoria Mountain in the Circle Quadrangle and the Tanana and Yukon Rivers junction in the Tanana Quadrangle (fig. 21). A reevaluation of earlier concepts of this unit is suggested by field studies in 1979 and later, and some of the regionally significant problems and alternate interpretations are summarized herein. The fault-bounded terrane concept, maximum age, possible regional correlations, and origin of the flysch unit, as well as the age and affinity of the adjacent vitreous quartzite unit (fig. 21), are not conclusively established. The rocks beneath the flysch belt and the nature of their 


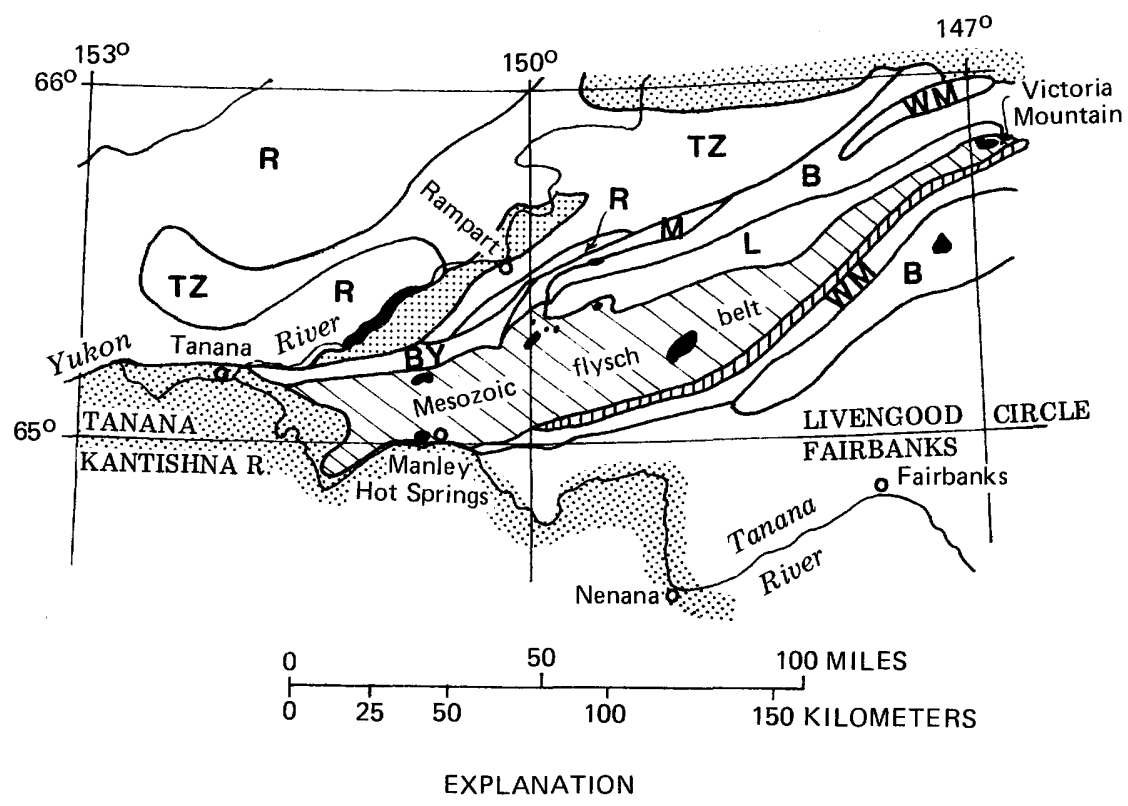

\author{
Terranes \\ B - Beaver (Churkin and others, 1982). \\ Similar to Wickersham (Jones and \\ others, 1984b). \\ BY - Baldry (Jones and others, 1984b). \\ L. Livengood (Churkin and others, 1982; \\ Jones and others, 1984b). \\ M - Minook (Jones and others, 1984b). \\ R - Ruby (Jones and others, 1984b). \\ TZ - Tozitna (Jones and others, 1984b). \\ WM - White Mountains (Churkin and others, \\ 1982; Jones and others, 1984b).
}

Figure 21.-Map showing the Mesozoic flysch belt, vitreous quarzite unit, and adjacent terranes in part of east-central Alaska.

contact with the flysch are unknown. Various origins of the flysch sequence may be interpreted, including: deposition in place, possibly overlying a now-concealed splay of the Tintina fault system; deposition in a closing basin in front of terranes converging from the south; or an allochthonous terrane emplaced along major strike-slip faults. Only recently the flysch belt has been described as a lithotectonic terrane-the Manley terrane by Jones and others (1984b), and as a terrane tentatively correlated with the lithologically similar Kandik River terrane about about $300 \mathrm{~km}$ to the east (Churkin and others, 1982).

The flysch unit of Chapman and others (1971, 1982) and Foster and others (1983) includes essentially unmetamorphosed graywacke, siltstone-argillite, shale, conglomerate, and quartzite. Slate and phyllite occur locally, and thermally altered flysch surrounds the Late Cretaceous and early Tertiary granitic intrusives (fig. 21). Due to discontinuous exposure and complex folding and faulting, the stratigraphic sequence and total thickness are not well known, but a 3-4 km thickness is inferred. Early Cretaceous and probable Late Jurassic ages of the flysch are based on poorly preserved shelly fossils found near the west edge of the Livengood Quadrangle. The flysch unit contacts have been mapped within narrow limits, but their exact nature is uncertain because they are typically concealed by surficial cover; only the southern contacts were interpreted as faults.

The northern contact of the flysch unit in the Livengood and Tanana Quadrangles has been interpreted (Chapman and others, 1971, 1982) as depositional, based on extensive polymictic conglomerates in the apparent basal flysch sequence and on lack of evidence for a major fault near the contact. However, mapping in the Circle Quadrangle shows a 
fault at the northern contact of the flysch unit (Foster and others, 1983). Immediately to the west in the Livengood Quadrangle, this contact lies between intensely sheared flysch and Livengood terrane Paleozoic sedimentary and mafic rocks and may also be reinterpreted as a fault. In the north contact zone, at long $150^{\circ} \mathrm{W}$., a sequence of Triassic radiolarian chert and clastic rocks of the flysch unit in apparently conformable structural association was found in 1981-82 (Jones and others, 1984a). It is not clear whether this is a true depositional sequence or a concealed fault relation.

The southern contact of the flysch belt in the Livengood Quadrangle has been mapped as a concealed fault. South of this inferred fault, a distinctive light-gray vitreous quartzite crops out, which is tens of meters thick and has no discernable sedimentary structures or fossils. It is interpreted to be of Ordovician age (Chapman and others, 1971). This quartzite forms a narrow, discontinuous outcrop belt that extends from Victoria Mountain through the eastern half of the Livengood Quadrangle (fig. 21 , becomes less prominent farther west, and is absent in the Tanana and Kantishna River Quadrangles.

An alternate interpretation of an Early Cretaceous age for the vitreous quartzite is suggested here. Supporting evidence includes an apparent structural and stratigraphic accordance of the quartzite with the flysch unit, and its lithologic and stratigraphic analogy to the basal Keenan Quartzite of the Lower Cretaceous Kandik Group in the Charley River area to the east (Churkin and others, 1982). Other possible equivalents of the Keenan Quartzite are unknown in the flysch belt sequence, which otherwise resembles the Kandik sequence. Dissimilarities include; (1) the absence of fossils in the vitreous quartzite, whereas the Keenan Quartzite contains Buchia of Valanginian age; (2) the presence of gabbroic intrusives in the vitreous quartzite but not in the Keenan Quartzite; and (3) the absence of a vitreous quartzite at the apparent base of the flysch on the north side of the belt. The vitreous quartzite and "Keno Hill Quartzite" (Tempelman-Kluit, 1970) of Yukon Territory, Canada, have suggestive affinities. They are lithologically similar, both are intruded by gabbroic rocks, and the Keno Hill and two overlying clastic units, all lacking definitive fossils, are interpreted by Tempelman-Kluit (1970) as of Early Cretaceous age and homotaxial equivalents of the Keenan Quartzite and Kandik Group. On the other hand, Blusson (1978) suggests that the Keno Hill assemblage may be upper Paleozoic and equivalent to part of the Alaskan Rampart Group, assuming about $500 \mathrm{~km}$ offset along the Tintina fault. The vitreous quartzite and adjacent rocks do not fit this analogy.

Ordovician Fossil Creek Volcanics and Silurian and Devonian Tolovana Limestone of the White Mountains terrane bound the vitreous quartzite on the south along an interpreted high-angle reverse fault (Churkin and others, 1982). The vitreous quartzite does not reappear on the south side of this synform terrane where the Beaver terrane of Churkin and others (1982) is in poorly exposed and probable fault contact. The quartzite, argillite, phyllite, slate, chert, and limestone of the Beaver terrane in part are dated by Oldhamia as Cambrian and (or) late Precambrian (Hofmann and Cecile, 1981). Conceivably, the vitreous quartzite could be part of the Beaver terrane sequence and would underlie the White Mountains terrane. Problems with this hypothesis include the absence of a true vitreous quartzite in the Beaver terrane and the uncertainty about the lower contact of the White Mountains terrane (since the base of the Fossil Creek Volcanics is not exposed). In addition, vitreous quartzite is absent in the northeastern corner of the Livengood Quadrangle (fig. 21), where the Beaver terrane encluses a block of the White Mountains terrane.

\section{REFERENCES CTTED}

Blusson, S. L., 1978, Regional geologic setting of lead-zinc deposits in Selwyn Basin, Yukon; Current research, Part A: Geological Survey of Canada Paper 78-1A, p. 77-80.

Chapman, R. M., Weber, F. R., and Taber, Bond, 1971, Preliminary geologic map of the Livengood Quadrangle, Alaska: U.S. Geological Survey Open-File Report 71-66, 2 sheets, scale $1: 250,000$.

Chapman, R. M., Yeend, Warren, Brosge , W. P., and Reiser, H. N., 1982, Reconnaissance geologic map of the Tanana Quadrangle, Alaska: U.S. Geological Survey Open-File Report 82-734, 18 p., 1 map, scale $1: 250,000$.

Churkin, Michael, Jr., Foster, H. L., Chapman, R.M., and Weber, F. R., 1982, Terranes and suture zones in east central Alaska: Journal of Geophysical Research, v. 87, no. B5, p. 3718-3730.

Foster, H. L., Laird, Jo, Keith, T. E. C., Cushing, G.W., and Menzie, W. D., 1983, Preliminary geologic map of the Circle Quadrangle, Alaska: U.S. Geological Survey Open-File Report 83-170-A, 30 p., 1 map, scale $1: 250,000$.

Hofmann, H. J., and Cecile, M. P., 1981, Occurrence of Oldhamia and other trace fossils in lower Cambrian(?) argillites, Niddery Lake map area, Selwyn Mountains, Yukon Territory: Geological Survey of Canada Paper 81-1A, p. 281-190.

Jones, D. L., Silberling, N. J., Chapman, R. M., and Coney, Peter, 1984a, New ages of radiolarian cherts from the Rampart district, east-central Alaska, in Coonrad, W. L., and Elliott, R. W., eds., The United States Geological Survey in Alaska-Accomplishments during 1981: U.S. Geological Survey Circular 868, p. $39-43$. 
Jones, D. L., Silberling, N. J., Coney, P. J., and Plafker, George, 1984b, Lithotectonic terrane map of Alaska (west of the 141st Meridian), in Silberling, N. J., and Jones, D. L., eds., Lithotectonic terrane maps of the North American Cordillera: U.S. Geological Survey Open-File Report 84-523, Part A, p. A1-A12.

Tempelman-Kluit, D. J., 1970, Stratigraphy and structure of the "Keno Hill Quartzite" in Tombstone River-Upper Klondike River mapareas, Yukon Territory: Geological Survey of Canada Bulletin 180, p. 7-43.

Reviewers: H. L. Foster and W. P. Brosge

\section{MAJOR ROCK PACKAGES OF THE RAY MOUNTAINS, TANANA AND BETTLES QUADRANGLES}

\section{by James H. Dover and Ronny T. Miyaoka}

The Ray Mountains segment of the Ruby geanticline, along the southeast margin of the YukonKoyukuk basin, consists of three diverse and complex rock packages-informally referred to here as the metamorphic suite of the Ray Mountains, the Kanuti assemblage, and the Rampart assemblage (fig. 22). The metamorphic suite of the Ray Mountains contains multiply deformed and polymetamorphosed, metasedimentary and meta-igneous rocks that display prominent blastomylonitic fabrics produced by ductile deformation during metamorphism. The polymetamorphic rocks are structurally bounded on the northwest by the Kanuti assemblage and on the southeast by the Rampart assemblage. The middle Cretaceous Ray Mountains batholith was intruded mainly into the metamorphic suite but locally cuts the adjacent Kanuti and Rampart alloch thonous assemblages.

Five informal units are recognized in the metamorphic suite of the Ray Mountains (fig. 22). The structurally lowest two (units 1 and 2) may be parautochthonous; the other three (units 3-5) comprise a structurally complex allochthon that extends across the range.

Quartzofeldspathic paragneiss (unit 1) is coarsely granoblastic and contains 70-85 percent quartz, 10-20 percent intermediate plagioclase, and 2-10 percent mica. Most samples also contain a few percent of untwinned $\mathrm{K}$-feldspar, and many have up to 5 percent garnet and(or) cordierite. The protolith was a slightly argillaceous, feldspathic, quartzrich sediment of continental derivation but uncertain age and probably represents basement.

A distinctive augen orthogneiss unit (unit 2) contains augen of igneous plagioclase, granulated quartz and plagioclase, or poikilitic, simply twinned $\mathrm{K}$-feldspar, in a cataclastic matrix of quartz, feldspar, and synkinematic micas. Rocks with similar composition and texture found elsewhere around the margin of the Yukon-Koyukuk basin yield Middle Devonian to Early Mississippian U-Pb zircon and $\mathrm{Rb}-\mathrm{Sr}$ whole rock ages (Dillon and others, 1978). The orthogneiss is probably intrusive into unit 1 .

The most widely distributed and variable of the metamorphic units is pelitic to quartzitic schist (unit 3). Subordinate interlayers are micaceous quartzofeldspathic schist, calc-schist or calc-silicate gneiss, amphibolitic schist, quartzite, marble, phyllonite, and, at one locality, metaconglomerate with metabasite clasts up to cobble size. Quartz segregation layering and blastomylonitic fabric are characteristic, and bedding is strongly transposed along the main foliation, which parallels axial surfaces of isoclinal folds. The schist ranges widely in texture and mineralogy because of complex interaction between multiple deformation and polymetamorphic recrystallization. Low $\mathrm{P} / \mathrm{T}$ amphibolitefacies assemblages $\left(M_{1}\right)$ formed during main-phase isoclinal folding $\left(\mathrm{F}_{1}\right) ; \mathrm{M}_{1}$ minerals occur as relies in rocks later subjected to a cataclastic $\left(\mathrm{F}_{2}\right)$, lowgrade retrogressive event $\left(\mathrm{M}_{2}\right)$. Typical $\mathrm{M}_{2}$ greenschist-facies mineral assemblages represent moderate to high $\mathrm{P} / \mathrm{T}$ conditions and include glaucophane at one locality. Post-kinematic minerals of the hornblende-hornfels facies $\left(\mathrm{M}_{3}\right)$ occur in a narrow aureole around the Ray Mountains pluton. The protolith of most of the schist was siliceous argillite and argillaceous feldspathic to calcareous quartz-rich sediment, possibly with primary alternations of quartzofeldspathic and argillaceous layers.

Metamorphosed mafic igneous rocks (unit 4) occur in the metamorphic suite of the Ray Mountains as large, mappable bodies ranging from metagabbro and metadiabase to amphibolite and garnetamphibolite, and as thin interlayers of amphibolitic schist in the pelitic schist unit. Local variations in the intensity of shearing produced gradations in fabric and degree of recrystallization, ranging from weakly sheared and incompletely recrystallized cores of large bodies to strongly foliated and recrystallized margins. Mineral assemblages indicate metamorphic conditions near the greenschistamphibolite facies transition.

A few interbeds of relatively pure quartzite and marble occur in unit 3 , but beds thick enough to map separately (unit 5) are most closely associated with the thick metabasite sheets of the southern Ray Mountains.

Two tectonically juxtaposed units form the Kanuti assemblage (W. W. Patton, Jr., written commun., 1983). The basal chert-basalt unit contains discontinuous and largely unsheared blocks and lenses of incipiently recrystallized basalt, diabase, gabbro, and serpentinized ultramafic rocks, in a cataclastic matrix of low-grade (greenschist facies) metasedimentary rocks, that include Triassic bedded chert, argillite, slate, Mississippian limestone, and volcanoclastic rocks (W. W. Patton, Jr., written commun., 1983). The structurally overriding unit contains cryptically deformed, extensively serpen- 


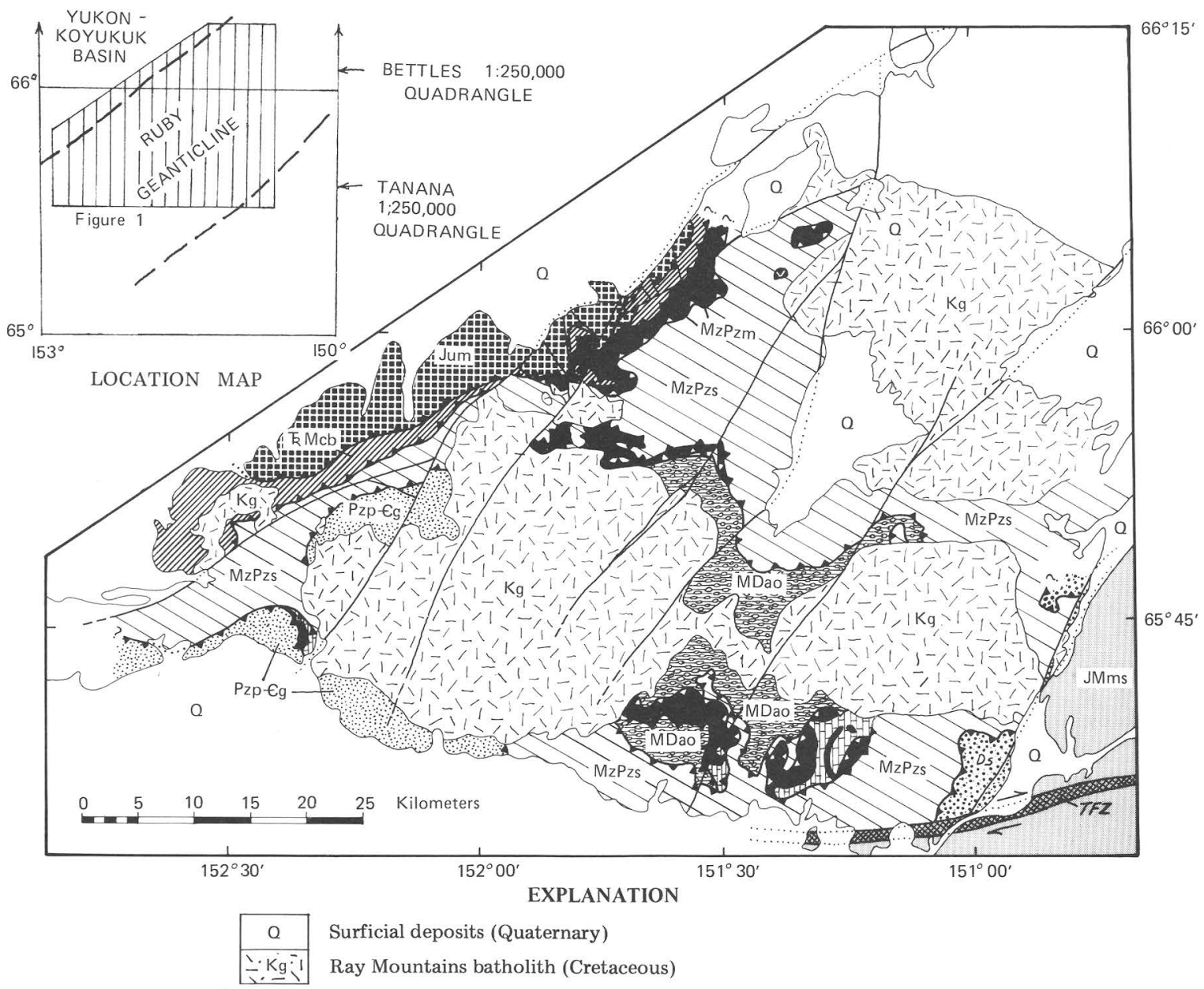

\section{KANUTI ASSEMBLAGE}

Serpentinized mafic and ultramafic rocks (Jurassic)

Chert-basalt unit (Triassic to Mississippian)

RAMPART ASSEMBLAGE

\begin{tabular}{|c|}
\hline JMms \\
\hline Ds \\
\hline \\
\hline
\end{tabular}

Rampart Group and associated intrusive rocks--sedimentary and mafic ingeous rocks (Jurassic to Mississippian?)

Mylonitic bimodal quartz-wacke and associated sedimentary rocks (Devonian?)

\section{METAMORPHIC SUITE OF THE RAY MOUNTAINS}

MzPzs Pelitic to quartzitic schist (Mesozoic and (or) Paleozoic)

$\widehat{\mathrm{MzPzm}}$ Metabasite (Mesozoic and (or) Paleozoic)

$M$
$M z P z q$ Quartzite and marble (Mesozoic and (or) Paleozoic)

MDao Augen orthogneiss (Mississippian? to Devonian?)

Pzp $€$ Quartzofeldspathic paragneiss (Paleozoic and (or) Precambrian?)

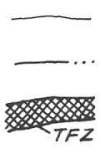

Contact

High-angle normal or oblique-slip fault, dotted where concealed

Tozitna fault zone--high-angle fault zone with major right-lateral strike-slip component of movement

$\ldots$ Thrust fault, sawteeth on upper plate. Dotted where concealed

Figure 22.--Simplified geologic map of the Ray Mountains, Tanana and Bettles Quadrangles. 


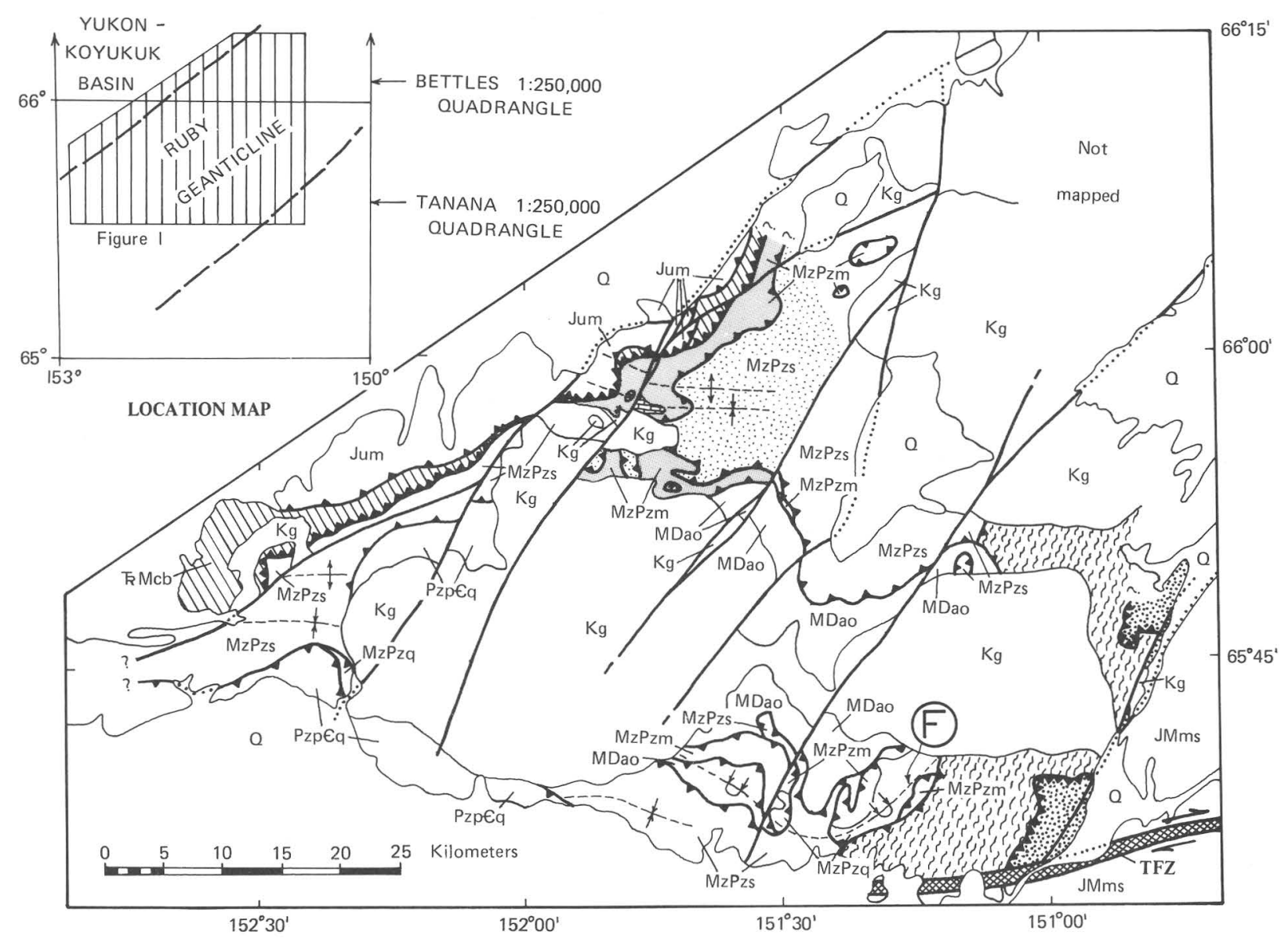

Figure 23.--Simplified structure map of the Ray Mountains, Tanana and Bettles Quadrangles. Major fold axes are shown; areas represented on stereograms are patterned. Explanation for this figure is on page 35 .

tinized, layered gabbro, peridotite, harzburgite, and dunite, with garnet-amphibolite (derived from eclogite?) at the base. K-Ar hornblende ages from amphibolite are 138, 149, and 161 m.y. (W. W. Patton, Jr., written commun., 1983). Primary igneous and sedimentary textures and mineralogy are typically preserved in the Kanuti assemblage.

The term Rampart assemblage as used here includes the Rampart Group of Mertie (1937), as well as associated mafic intrusive rocks. The Rampart Group contains basalt, pillow basalt, phyllite, argillite, slate, arkosic semischist, volcaniclastic rocks, conglomerate, Permian limestone, and radiolarian chert of Mississippian-Triassic ages (Jones and others, 1984). Intrusive rocks included in the Rampart assemblage are mainly diabase and gabbro with subordinate diorite and minor serpentinized ultramafic rocks. A K-Ar hornblende age of $205 \pm 6 \mathrm{~m} . \mathrm{y}$. is reported by Brosge and others (1969) for gabbro near Rampart.
Also tentatively included here in the Rampart assemblage are low-grade cataclastic rocks that structurally underlie the Rampart Group in the southeastern Ray Mountains. Mylonitic quartz-wacke with bimodal quartz grain-size distribution is the dominant and most distinctive lithology. Associated rocks are contorted phyllite, platy arenaceous(?) limestone, poorly sorted limonitespotted quartzite with limy cement, and pebbly mudstone with clasts as large as $2 \mathrm{~cm}$ in diameter of limestone, quartz, quartzite, chert, argillite, and feldspathic quartz-arenite. Igneous and metamorphic clasts are conspicuously absent. As in the Kanuti assemblage, mylonites of the Rampart assemblage underwent only incipient $\mathrm{M}_{2}$ and locally $\mathrm{M}_{3}$ metamorphism through which primary sedimentary textures and mineralogy are still clearly recognizable. No local evidence was found for the protolithic age of the mylonitic rocks, but similar rocks that structurally(?) underlie mafic intrusive-bearing 


\section{EXPLANATION}

\begin{tabular}{|c|c|}
\hline $\mathrm{Q}$ & Surficial deposits (Quaternary) \\
\hline $\mathrm{Kg}$ & Ray Mountains batholith (Cretaceous) \\
\hline & KANUTI ASSEMBLAGE \\
\hline Jum & Serpentinized mafic and ultramafic rocks (Jurassic) \\
\hline इMcb & Chert-basalt unit (Triassic to Mississippian) \\
\hline & RAMPART ASSEMBLAGE \\
\hline $\mathrm{JMms}$ & $\begin{array}{l}\text { Rampart Group and associated intrusive rocks--sedimentary and mafic } \\
\text { igneous rocks (Jurassic? to Mississippian) }\end{array}$ \\
\hline Ds & $\begin{array}{l}\text { Mylonitic bimodal quartz-wacke and associated sedimentary rocks } \\
\text { (Devonian?) }\end{array}$ \\
\hline & METAMORPHIC SUITE OF THE RAY MOUNTAINS \\
\hline & $\begin{array}{l}\text { Pelitic to quartzitic schist (Mesozoic and (or) Paleozoic) -patterned only } \\
\text { in area of northwestern Ray Mountains represented in fig. } 26\end{array}$ \\
\hline 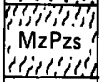 & $\begin{array}{l}\text { Pelitic to quartzitic schist (Mesozoic and (or) Paleozoic) --pattern shows } \\
\text { phyllonite in southeastern Ray Mountains represented in fig. } 26\end{array}$ \\
\hline & $\begin{array}{l}\text { Metabasite (Mesozoic and (or) Paleozoic)--patterned only in area of } \\
\text { northwestern Ray Mountains represented in fig. } 26\end{array}$ \\
\hline MzPzq & $\begin{array}{l}\text { Quartzite and marble (Mesozoic and (or) Paleozoic) -patterned only in area } \\
\text { of northwestern Ray Mountains represented in fig. } 26\end{array}$ \\
\hline MDao & Augen orthogneiss (Mississippian? to Devonian?) \\
\hline Pzp $€ g$ & Quartzofeldspathic gneiss (Paleozoic and (or) Precambrian?) \\
\hline & Contact \\
\hline & High-angle normal or oblique-slip fault, dotted where concealed \\
\hline & $\begin{array}{l}\text { Tozitna fault zone--high-angle brittle-shear zone with major right-lateral } \\
\text { strike-slip component of movement }\end{array}$ \\
\hline & Thrust fault, sawteeth on upper plate \\
\hline & Ductile thrust zone separating major rock sequences, sawteeth on upper plate \\
\hline & MAJOR FOLD AXIS \\
\hline & Antiform \\
\hline & Synform \\
\hline & Overturned synform \\
\hline & Locality cited in text \\
\hline
\end{tabular}

rocks correlative with the Rampart Group elsewhere east of the Ruby geanticline are Devonian (Dss and related units of Brosge and others, 1973). In the Ray Mountains, the Rampart assemblage appears to differ significantly from the Kanuti assemblage in lithologic and petrologic detail and relative proportions of rock types, and especially in its close association with the Devonian(?) quartzwacke-bearing sequence.

\section{REFERENCES CITED}

Brosge, W. P., Lanphere, M. A., Reiser, H. N., and Chapman, R. M., 1969, Probable Permian age of the Rampart Group, central Alaska: U.S. Geological Survey Bulletin 1294-B, 18 p.
Brosge, W. P., Reiser, H. N., and Yeend, Warren, 1973, Reconnaissance geologic map of the Beaver Quadrangle, Alaska: U.S. Geological Survey Map MF-525, 1 sheet, scale 1:250,000. Chapman, R. M., Yeend, Warren, Brosge, W. P., and Reiser, H. N., 1982, Reconnaissance geologic map of the Tanana Quadrangle, Alaska: U.S. Geological Survey Open-File Report 82-734, 20 p., 1 sheet, scale $1: 250,000$.

Dillon, J. T., Pessel, G. H., Chen, J. A., and Veach, N. C., 1978, Tectonic and economic significance of Upper Devonian and late Proterozoic $\mathrm{U}-\mathrm{Pb}$ zircon ages from the Brooks Range, Alaska: Alaska Division of Geologic and Geophysical Surveys Geologic Report 61, p. 36-41. 
Jones, D. L., Silberling, N. J., Chapman, R. L., and Coney, P., 1984, New ages of radiolarian chert from the Rampart district, eastcentral Alaska, in Coonrad, W. L., and Elliott, R. L., eds., The United States Geological Survey in Alaska-Accomplishments during 1981: U.S. Geological Survey Circular 868, p. 39-43.

Mertie, J. B., Jr., 1937, The Yukon-Tanana region, Alaska: U.S. Geological Survey Bulletin 872, $276 \mathrm{p}$.

Patton, W. W., Jr., 1973, Reconnaissance geology of the northern Yukon-Koyukuk Province, Alaska: U.S. Geological Survey Professional Paper 774-A, $18 \mathrm{p}$.

Reviewers: D. J. Grybeck and M. L. Miller

\section{METAMORPHIC ROCKS OF THE RAY MOUNTAINS- \\ PRELIMINARY STRUCTURAL ANALYSIS AND REGIONAL TECTONIC IMPLICATIONS}

\section{by James H. Dover and Ronny T. Miyaoka}

The three major rock packages of the Ray Mountains-the metamorphic suite of the Ray Mountains, and the structurally bounding Kanuti and Rampart assemblages-are briefly described in the preceding article (Dover and Miyaoka, this volume). We report here on preliminary results of structural and metamorphic studies in the Ray Mountains and some regional tectonic implications.

Most map contacts within the metamorphic suite of the Ray Mountains, and some contacts bounding it, are shallow-dipping, structurally discordant blastomylonite zones in which ductile shear proceeded under low-grade metamorphic conditions (fig. 23, p. 34, 35). Several major folds have axes oriented generally east-west, oblique to the contacts of bounding allochthons, and axes on the south side of the range verge north (fig. 23).

Although data are incomplete, preliminary analysis suggests that the mesoscopic fabric of the metamorphic terrane involves at least three deformational phases and three metamorphic episodes. The earliest folds $\left(F_{1}\right)$ are isoclines to which the main schistosity $\left(\mathrm{S}_{1}\right)$ is axial planar. $\mathrm{F}_{1}$ axes commonly parallel major fold axes. In thin section, $\mathrm{F}_{1}$ isoclines are associated with synkinematic amphibolite-facies minerals $\left(M_{1}\right)$. Snowball structure occurs locally in garnet and intermediate plagioclase. The age of first-generation deformation and metamorphism is unknown. $F_{1}$ isoclines are overprinted by second generation folds $\left(\mathrm{F}_{2}\right)$ of variable style and that have axial plane cleavage $\left(\mathrm{S}_{2}\right)$ at a low to moderate angles with $S_{1}$ (fig. 24). Most $F_{2}$ folds are small chevron folds or crenulations, but in places these grade into folds with tight or even isoclinal styles. Tight $F_{2}$ folds increase in abundance toward cataclastic zones between major rock units and se- quences, where the cataclastic foliation is the dominant fabric element and appears to coincide with $\mathrm{S}_{2}$. Second-generation structures throughout the Ray Mountains are invariably associated with greenschist-facies mineral assemblages $\left(\mathrm{M}_{2}\right)$. In rocks not strongly affected by the cataclastic event, $\mathrm{M}_{2}$ produced relatively minor retrogression of $\mathrm{M}_{1}$ minerals. In more strongly cataclasized rocks, many of "phyllitic" aspect, $\mathrm{M}_{1}$ minerals are locally preserved as granulated or pseudomorphic relics cut by cataclastic $S_{9}$ foliation with synkinematic $\mathrm{M}_{2}$ greenschist mineral assemblages; at one locality, glaucophane occurs with chloritoid in a glaucophanitic greenschist-facies assemblage. Such rocks are retrogressive phyllonites. We tentatively regard all the graphitic chlorite-muscovite-quartz schist of the Ray Mountains as blastomylonite produced or affected by the $\mathrm{M}_{2}$ cataclastic event, and some of these rocks are demonstrably phyllonitic. The age of cataclasis appears to be bracketed between the probable Jurassic age of mafic igneous rocks in the Kanuti and Rampart assemblages and the middle Cretaceous age of the Ray Mountains batholith. In parts of the Ray Mountains not strongly affected by the cataclastic event, broad warps $\left(\mathrm{F}_{3}\right)$ bend earlier structures in individual outcrops; $\mathrm{F}_{1}$ and $\mathrm{F}_{3}$ are coaxial in places. In strongly cataclasized zones, $\mathrm{F}_{3}$ folds are small crenulations that fold synkinematic $M_{2}$ minerals and have only incipiently recrystallized axial plane cleavage $\left(S_{3}\right)$ that cuts the cataclastic $S_{2}$ foliation. Post-kinematic hornblende-hornfels facies assemblages $\left(\mathrm{M}_{3}\right)$ occur in a contact metamorphic aureole around the middle Cretaceous Ray Mountains pluton.

Fabric data from mylonitic, bimodal quartzwacke at the base of the Rampart assemblage in the southeastern Ray Mountains (fig. 23) are fairly sparse but geometrically simple and consistent (fig. $25 \mathrm{~A}$ ). The data reflect broadly folded but generally southeast-dipping mylonitic foliation and related linear structures compatible with northwest-

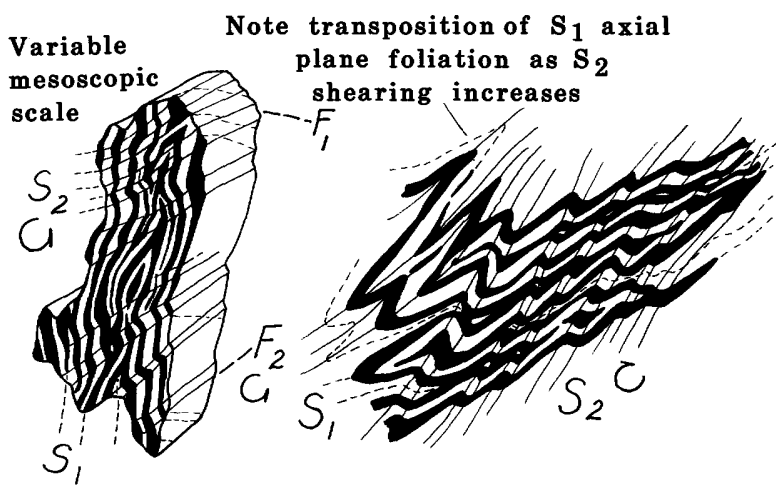

Figure 24.--Sketches of superimposed mesoscopic structures. Quartz segregation layers in white; mica-rich layers in black. Arrows show sense of rotation of asymmetric folds. 


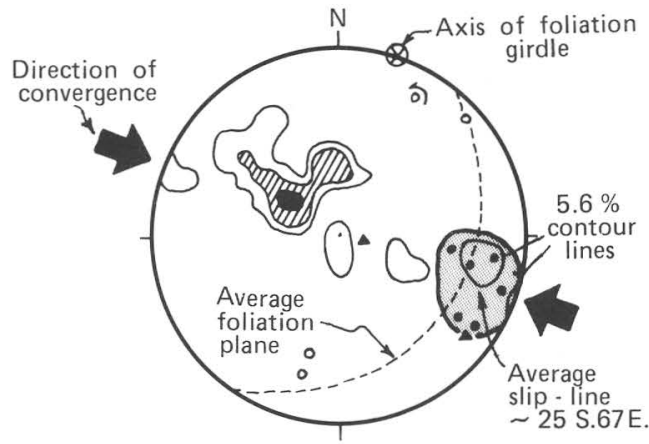

Contours on 18 poles to $S_{2}$ foliation

$5.6 \%$

DIIIS $11.1-22.2 \%$

$27.8-33.3 \%$

(o Isocline axis (arrow shows asymmetry)

- Mineral lineation

A. Other lineation

Slip field

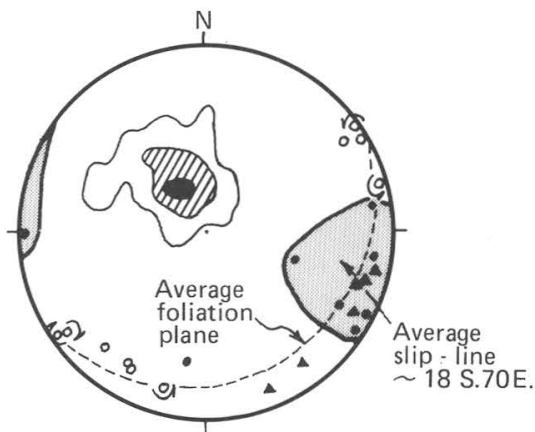

Contours on 20 poles to $\mathrm{S}_{2}$ foliation

$$
5 \% \text { \% } 10.20 \% \text { \% } 25 \%
$$

(o) Isocline axis (arrow shows asymmetry)

- Mineral lineation

B.

• Other lineation

Slip field

Figure 25.--Stereograms of structural data, southeastern Ray Mountains. A, quartz-wacke; B, phyllonite. Contours represent percent of points per one percent area.

southeast movement of the Rampart allochthon. Similar fabric elements and orientations are displayed by the thick phyllonite unit separating the Rampart assemblage from the rest of the metamorphic terrane, except that $\mathrm{F}_{1}$ folds not present in the quartz-wacke are represented in the phyllonite data (fig. 25B). The similarity in data suggests that movement of the Rampart allochthon induced the cataclastic $\mathrm{S}_{2}$ fabric of the phyllonite. Two lines of evidence suggest that the Rampart allochthon may have moved up-dip from southeast to northwest toward the Ruby geanticline: (1) five of six asymmetrical folds measured in these two rock sequences have b-axes that verge northwestward (fig. 25), and (2) a major east-west fold axis in the metamorphic terrane appears to be deflected under the phyllonite in a manner suggesting northwest overriding (locality F, fig. 23 ). If this direction of movement is confirmed by mylonite fabric studies now in progress, models relating the Kanuti and Rampart assemblages to the same regional overthrust sheet will need to be modified.

Contact relations between the Kanuti assemblage and the metamorphic suite of the Ray Mountains are poorly exposed and unclear. Although phyllonite produced by $\mathrm{M}_{2}$ cataclasis underlies most segments of the Kanuti allochthon, cataclasis varies in intensity along the contact, and phyllonite may be absent in places. In fact, the strongest $\mathrm{M}_{2}$ cataclasis marks contacts between units within the metamorphic suite. Moreover, the statistical trend of isoclinal folds in phyllonitic rocks is $\mathrm{N} .60^{\circ} \mathrm{W}$., oblique to the $\mathrm{N} .60^{\circ} \mathrm{E}$. trace of the Kanuti contact (fig. 26). Few fabric data are available for the Kanuti assemblage itself, but at one locality in the chert-basalt unit, bedded chert displays three phases of folding somewhat similar in style and orientation to those of the adjacent metamorphic suite (fig. 26). Three interpretations are being considered for isoclinal folds in and under the Kanuti assemblage. They could be: (1) $\mathrm{F}_{1}$ structures whose degree of preservation in the zone of $\mathrm{M}_{2}$ cataclasis is anomalous. If so, their presence in the Kanuti chert-basalt belt suggests that the Kanuti assemblage participated in $F_{1}$ folding prior to its emplacement on the metmorphic suite of the Ray Mountains. (2) $\mathrm{F}_{2}$ structures related to cataclasis that are indistinguishable in style and trend from $\mathrm{F}_{1}$ folds. In this case, the isoclines are either N. $60^{\circ} \mathrm{W}$.-trending a-lineations that record direction of movement of the Kanuti assemblage or blineations that resulted from more complex interaction of the Kanuti with the metamorphic suite of the Ray Mountains, such as oblique convergence or multistage movement. (3) $\mathrm{F}_{3}$ structures that postdate $\mathrm{M}_{2}$ cataclasis and were overprinted on both the phyllonite and the chertbasalt unit after their tectonic juxtaposition.

We expect more detailed analysis of available data to help clarify structural relations at the contact of the Kanuti assemblage and the metamorphic suite of the Ray Mountains. In any case, simple thrusting of the Kanuti assemblage southeastward out of the Yukon-Koyukuk basin is not clearly expressed in the fabric of the chert-basalt unit nor in phyllonite of the underlying metamorphic rocks of the Ray Mountains.

In the Ray Mountains, where isoclinally folded, medium- to high-grade rocks of the metamorphic suite were overprinted by a low-grade cataclastic event, the resulting gradation from coarsely granoblastic to phyllonitic rocks represents the destructive and retrogressive breakdown of a coarser grained and higher grade protolith rather than pro- 


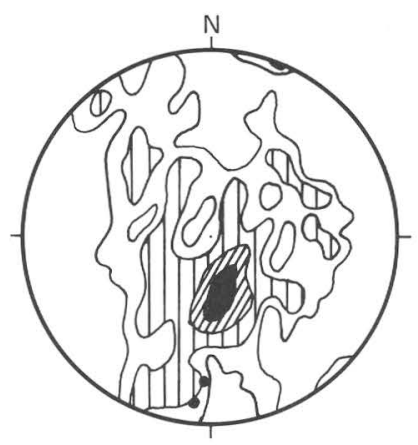

Contours on 92 poles to foliation

$\square 1.1 \%$ पण $2.1-4.3 \%$ पाW $5.4-8.6 \%$
$9.6-10.7 \%$
Pole to foliation in Kanuti
chert - basalt belt

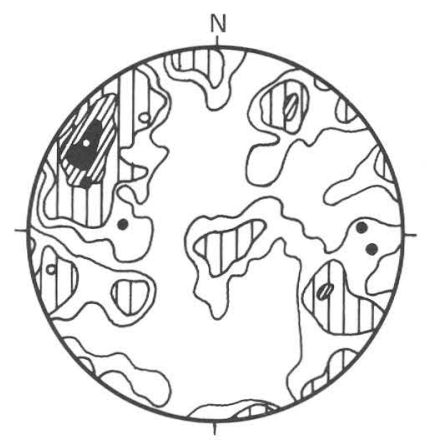

Contours on 103 lineations

$\square 1.0 \%$ WD $1.9-3.9 \%$ WDII $4.9-11.6 \%$
$12.6-13.6 \%$
- Fold axis in Kanuti chert - basalt unit
- Major fold axis

Figure 26.--Contoured stereograms of structural data from schist, metabasite, and marble, northwestern part of Ray Mountains metamorphic suite. Data from the Kanuti chert-basalt unit and major folds are superimposed. Contours represent percent of points per one percent area.

gradation from phyllite to schist. In contrast, the Kanuti and Rampart allochthons contain true phyllites and mylonite formed during tectonic emplacement. Thus, thrusts bounding the major sequences of the Ray Mountains appear to be zones of lowgrade metamorphic convergence where retrogressive phyllonite and prograde phyllite are juxtaposed. Production of retrogressive phyllonite from metamorphic protoliths may have occurred elsewhere in the Yukon-Koyukuk borderlands.

\section{REFERENCE CITED}

Dover, J. H., and Miyoka, R. T., 1985, Major rock packages of the Ray Mountains, Tanana and Bettles Quadrangles: this volume

Reviewers: D. J. Grybeck and S. W. Nelson

\section{TERTIAR Y(?) FOLDING IN THE TANACROSS QUADRANGLE}

\section{by Helen L. Foster and Grant W. Cushing}

Overturned folds (figs. 27, 28, 29) are well exposed in a borrow pit along the Taylor Highway in the Tanacross D-3 Quadrangle (T. 24 N., R. 16 E., sec. 13). These folds occur in rocks of Late Cretaceous or Early Tertiary(?) age that were deposited in a small, isolated, nonmarine basin in the broad Paleozoic and Precambrian(?) terrane of the eastern Yukon-Tanana Upland of east-central Alaska. The probable age of this folding provides new insight into the little known late Mesozoic and Cenozoic tectonic history of this part of Alaska. The distribution of these rocks, as known from reconnaissance mapping, is shown on the geologic map of the Tanacross Quadrangle (Foster, 1970). The rocks have been described previously (Foster, 1967, p. B5B6) from a borrow pit $0.9 \mathrm{~km}$ north of the locality of the folds and $3.3 \mathrm{~km}$ south of the bridge over the West Fork of the Dennison Fork of the South Fork of the Fortymile River where it crosses the Taylor Highway, as well as from several small outcrops along tributaries of the West Fork east of the West Fork bridge. The area where these sedimentary rocks occur is heavily vegetated and topographically subdued, so outcrops are limited and confined largely to streams.

The folds occur in a section of tan, greenishgray, and reddish-brown tuffaceous sandstone and siltstone and siliceous and tuffaceous shale. They are overturned toward the southwest and have amplitudes and wavelengths ranging from approximately 0.5 to $3 \mathrm{~m}$. Fold axis orientations trend $\mathrm{N}$. $32^{\circ}-66^{\circ}$ W. and plunge $10^{\circ}-26^{\circ} \mathrm{NW}$. A fracture cleavage, rarely axial-planar, is present in most of the fine-grained lithologies. In one outcrop (fig. 29), a thrust fault with a strike of $N .75^{\circ} \mathrm{W}$. and a dip of $21^{\circ} \mathrm{NE}$. truncates beds. Direction of thrusting appears to be toward the southwest, as is the vergence of the major folds in the outcrop. At the locality $3.3 \mathrm{~km}$ south of the West Fork bridge, the rocks dip about 15-20 northward, but complete folds are not exposed and the size and style of folds is not evident.

The folded rocks are part of a nonmarine deposit that is estimated to be $70 \mathrm{~m}$ or more thick, although the thickest measurable sequence is $20 \mathrm{~m}$. The base of the formation (seen in a single exposure) consists of weathered conglomerate with a few sandstone interbeds. The conglomerate, lying unconformablv on well-foliated metamorphic rock, 
Figure 27.--Overturned fold in Cretaceous(?) nonmarine sedimentary rocks in the northern Tanacross Quadrangle. Direction of overturning is to the southwest.

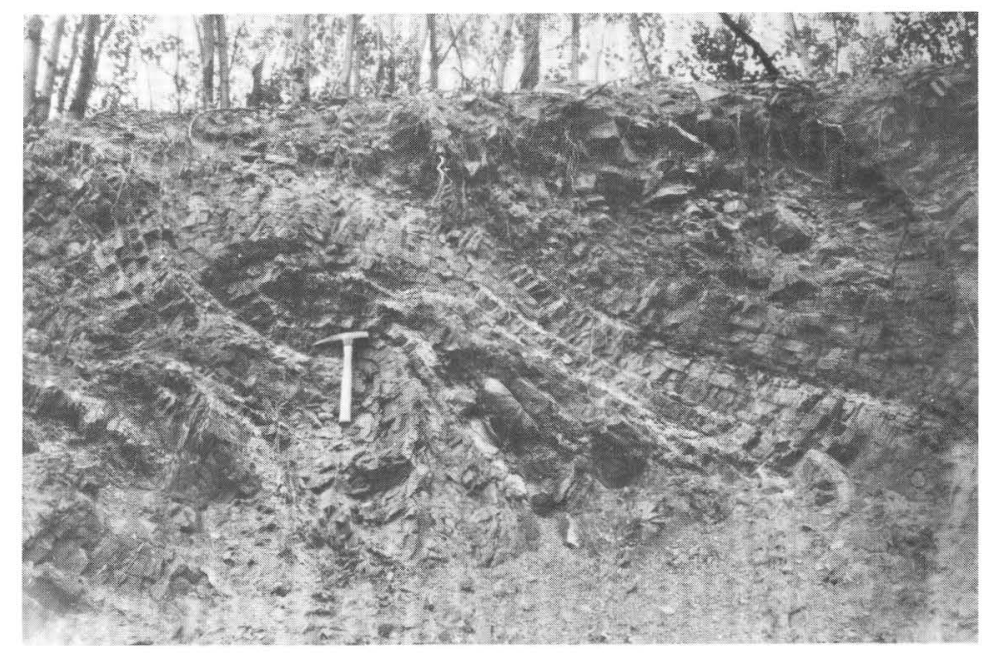

Figure 28.--Fold in Cretaceous(?) nonmarine sedimentary rocks, mostly fineto very fine grained tuffaceous argillites and sandstone, exposed a few meters northeast of fold shown in figure 27. View to the northwest.

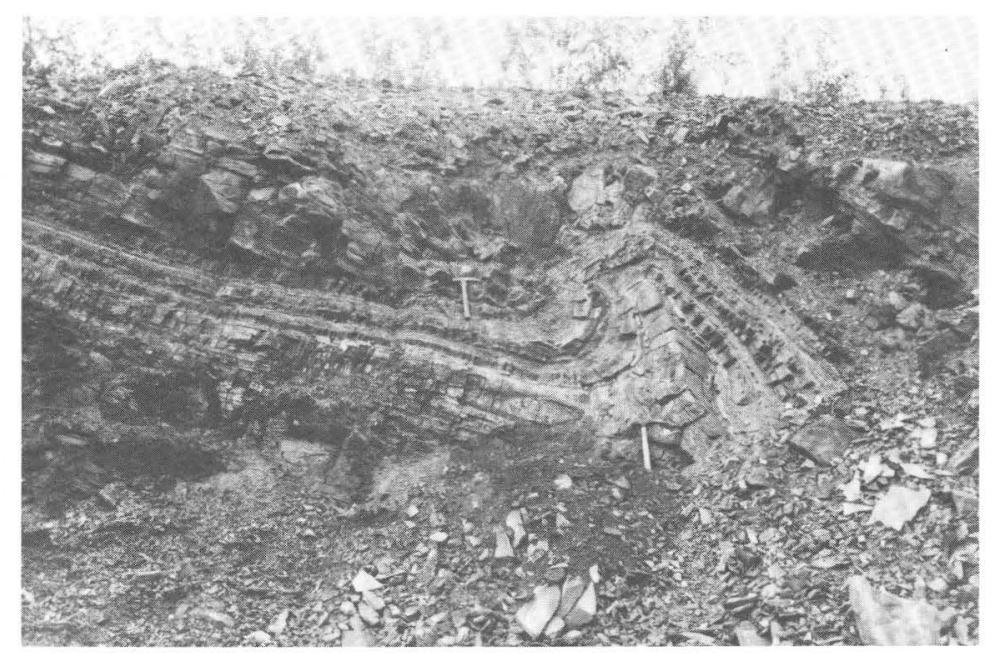

Figure 29.--A small thrust fault in folded Cretaceous(?) nonmarine sedimentary rocks. The head of the hammer is above, and the bottom of the handle is below, the thrust plane. The rocks are mostly fine-grained tuffaceous argillites and sandstones.

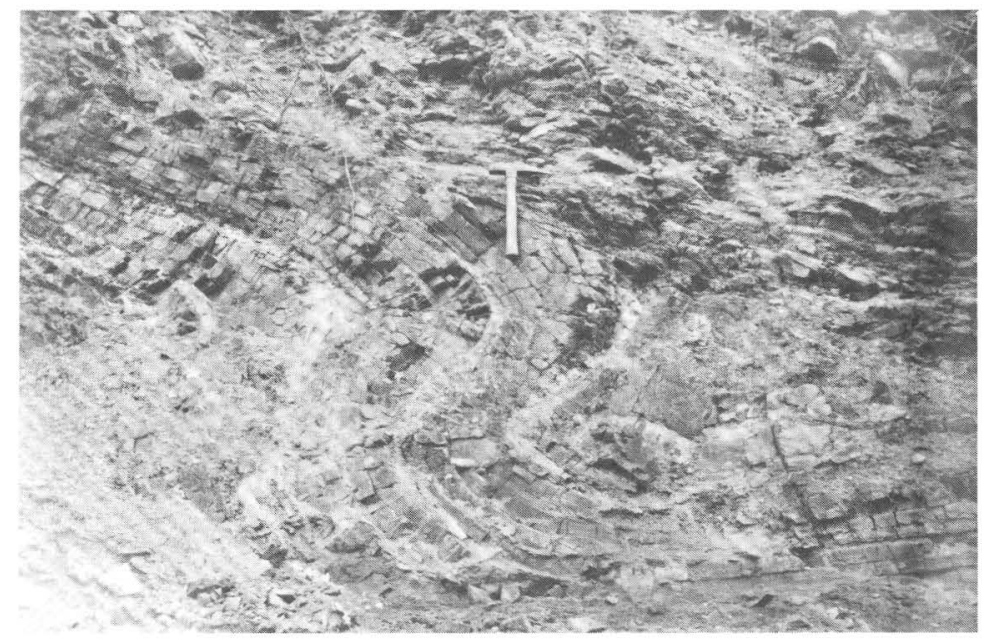


unconformably on well-foliated metamorphic rock, is composed primarily of clasts of well-rounded white translucent quartz, some quartzitic schist, and some greenish-gray volcanic clasts in an arkosic, slightly micaceous, matrix. Size of clasts ranges from about $0.15 \mathrm{~cm}$ to $5 \mathrm{~cm}$. The basal conglomerate is overlain by a succession, from the bottom to top of the section, of (1) tan and gray arkosic, quartzitic, and tuffaceous sandstone beds; (2) shale, tuffaceous shale, tuff, and siltstone; and (3) conglomeratic tuff, conglomeratic sandstone, and conglomerate. Some of the shales are very carbonaceous, containing plant remains and intercalated thin lignite beds. Some sandstone and tuffaceous sandstone beds also have carbonaceous fragments and plant impressions. Gray, red, tan, and banded gray and red fine-grained siliceous chert-like rock is found as float in one part of the borrow pit $3.3 \mathrm{~km}$ south of the West Fork bridge. Coarse conglomerate, with boulders $0.5 \mathrm{~m}$ in diameter, composes an exposure about $27 \mathrm{~km}$ east of the West Fork bridge. At the locality of the folds, the exposed rocks are mostly tuffaceous sandstone and siltstone and siliceous and tuffaceous shale.

A poorly preserved palynomorph flora was collected from nearby rocks prior to excavation of colluvium overlying the folds; the sample contains spores from a Late Devonian assemblage mixed with an assemblage of a more modern aspect, characterized by tricolpate, monosulcate, coniferous, and Aquilapollenites pollen (Foster, 1967). On the basis of the younger assemblage, a Late Cretaceous age was suggested for these sedimentary rocks, but because of the poor preservation of the organic material, a younger age could not be ruled out (Foster, 1967, p. B6). Additional pollen has been collected from the locality of the folds; these studies are not yet complete.

Evidence at the borrow pit demonstrates that a period of late folding postdates both the regional metamorphism and all or most igneous intrusive activity in the northern Tanacross Quadrangle. The folding is younger than Late Cretaceous in age, and it could be as young as middle or late Tertiary. In the Chicken area, $22 \mathrm{~km}$ to the northeast, vertically dipping sedimentary rocks of Tertiary age have been reported (Mertie, 1937, p. 262-263). Moderately to steeply dipping sedimentary rocks of probable middle to late Tertiary age also occur along Napoleon and Baby Creeks, in the southern Eagle Quadrangle (Foster, 1976).

Open folding, which postdates formation and folding of foliation, has previously been reported in the Yukon-Tanana Upland (Cushing and others, 1982; Cushing and Foster, 1982, 1984), but because the open folding was seen only in metamorphic rocks, few constraints could be placed on the time of its occurrence. Lack of metamorphism of the sedimentary rocks in the Tanacross Quadrangle, and the likely Late Cretaceous age of the rocks as indicated by the pollen, places a constraint on the earli- est time that the sedimentary rocks were folded. However, because nearby rocks as young as late Tertiary in age may also be folded, it is feasible that the latest deformation in this part of the Yukon-Tanana Upland took place in Tertiary time.

\section{REFERENCES CITED}

Cushing, G. W., and Foster, H. L., 1982, Recumbent folding in the northeastern Yukon-Tanana Upland, Alaska (abs.): Geological Society of America, Cordilleran Section, Abstracts with Programs, v. 14, no. 4, p. 158.

Cushing, G. W., and Foster, H. L., 1984, Structural observations in the Circle Quadrangle, YukonTanana Upland, Alaska, in Coonrad, W. L., and Elliott, R. L., eds., The United States Geological Survey in Alaska-Accomplishments during 1981: U.S. Geological Survey Circular 868, p. 64-65.

Cushing, G. W., Foster, H. L., Laird, Jo, and Burack, A. C., 1982, Description and preliminary interpretations of folds and faults in a small area in the Circle B-4 and B-5 Quadrangles, Alaska, in Coonrad, W. L., ed., The U.S. Geological Survey in Alaska-Accomplishments during 1980: U.S. Geological Survey Circular 844, p. $56-58$.

Foster, H. L., 1967, Geology of the Mount Fairplay area, Alaska: U.S. Geological Survey Bulletin 1241-B, p. B1-B18.

Foster, H. L., 1970, Reconnaissance geologic map of the Tanacross Quadrangle, Alaska: U.S. Geological Survey Miscellaneous Geologic Investigations Map I-593, 1 sheet, scale $1: 250,000$.

Foster, H. L., 1976, Geologic map of the Eagle Quadrangle, Alaska: U.S. Geological Survey Miscellaneous Investigations Series Map I-922, 1 sheet, $1: 250,000$.

Mertie, J. B., 1937, The Yukon-Tanana region, Alaska: U.S. Geological Survey Bulletin 872, $276 \mathrm{p}$.

Reviewers: R. M. Chapman and W. W. Patton, Jr.

STATISTICAL DISCRIMINATION BETWEEN
POTENTIAL TIN- AND URANIUM-BEARING
AREAS IN EAST-CENTRAL ALASKA
ON THE BASIS OF STREAM-SEDIMENT
TRACE-ELEMENT GEOCHEMISTRY

\section{by Gail M. Jones, W. David Menzie, and Helen $L_{\text {. }}$ Foster}

Both tin vein/greisen and peraluminous granite-hosted uranium deposits with mineralization occurring as disseminations in plutons or in nearby veins are associated with peraluminlous composite granitic plutons. In the Circle Quadrangle, both tin and uranium occurrences are known; tin occurs in 
the Lime Peak area (Menzie and others, 1983), and radioactive springs with anomalous amounts of uranium occur in the Mount Prindle area (Barker and Clautice, 1977).

Discriminant analyses were performed on the values obtained for trace-element geochemistry from stream-sediment sampies from the Lime Peak and Mount Prindle areas to determine if some elements analyzed for in the standard 30-element emission spectrographic method of analysis could successfully discriminate between areas of tin vein/greisen or peraluminous granite-hosted uranium occurrences. The trace-element concentrations in more than 30 stream-sediment samples from each area were determined by the six-step D$\mathrm{C}$ are semiquantitative emission spectrographic method (Grimes and Marranzino, 1968); zinc was determined by atomic absorption methods. The SPSS stepwise discriminant analysis computer program (Klecka, 1975) was used to analyze data for concentrations of $\mathrm{B}, \mathrm{Ba}, \mathrm{Be}, \mathrm{Co}, \mathrm{Cr}, \mathrm{Cu}, \mathrm{La}, \mathrm{Nb}, \mathrm{Li}, \mathrm{Pb}, \mathrm{Sc}$, $\mathrm{Sn}, \mathrm{Sr}, \mathrm{Th}, \mathrm{V}, \mathrm{Y}, \mathrm{Zn}$, and $\mathrm{Zr}$.

Discriminant analysis assumes that samples are randomly chosen with known probability from multivariate normal distributions having equal covariance matrices. Logarithms of the original values were used in an attempt to normalize their distributions (Rose and others, 1979, p. 32). Covariance matrices for the Lime Peak and Mount Prindle areas were significantly different from one another at 99-percent confidence level when tested by Box's M (Klecka, 1975). However, discriminant analysis is a robust method of data analysis; that is, while violations of assumptions may modify probability statements and discriminant coefficients to some extent, they rarely change conclusions when the probabilities of correct classification are high.

The elements V, Y, and $\mathrm{Zn}$ are indicators of the tin-bearing Lime Peak area, whereas $\mathrm{Nb}$ and Sc are indicators of the uranium-bearing Mount Prindle area. Table 7 shows standardized and unstandardized discriminant function coefficients and the discriminant scores of group means. The discriminant

Table 7 .--Coefficients of discriminant functions

$\begin{array}{cc}\text { Element } & \begin{array}{l}\text { Unstandardized } \\ \text { discriminant } \\ \text { function } \\ \text { coefficients }\end{array}\end{array}$

Standard discriminant

function coefficients

\begin{tabular}{lrr}
\hline & & \\
$\mathrm{Nb}$ & -1.429948 & -0.47349 \\
$\mathrm{Sc}$ & -2.344769 & -0.59945 \\
$\mathrm{~V}$ & 6.428939 & 1.10961 \\
$\mathrm{Y}$ & 2.622329 & 0.64000 \\
$\mathrm{Zn}$ & 3.961027 & 0.78701 \\
& & \\
\hline (Constant) & -21.66439 & - \\
\hline
\end{tabular}

score of a particular sample is found by: (1) taking the product of the unstandardized discriminant coefficient and the logarithm of the value for each element in the discriminant function; (2) summing these products; and (3) adding a constant. Thus, the equation for calculating the discriminant score is

$$
D=d N b x N b+d S c x S c+d V x V+d Y x Y+d Z n x Z n+C,
$$

where the $d$ is the unstandardized discriminant coefficient, $\mathrm{x}$ is the logarithm of the value, and $\mathrm{C}$ is a constant. Samples with positive discriminant scores are from the Lime Peak area, and those with negative scores are from the Mount Prindle area. Group means of the standardized discriminant function are 2.01838 for the Lime Peak area samples, and -1.7462 for the Mount Prindle area samples. Absolute values of the standardized discriminant coefficients indicate the relative effectiveness of an element as a discriminator; thus, $\mathrm{V}$ is the most important, and $\mathrm{Nb}$ the least important, discriminator. Table 8 shows the percentage of samples correctly classified, where group 1 samples are from the Lime Peak area and group 2 samples are from the Mount Prindle area. Stream-sediment samples from the Table Mountain, Circle mining district, and Chena Hot Springs areas (fig. 30) were classified by using the discriminant equation (table 7) to calculate discriminant scores. Results show that some samples from each of these areas have values similar to both the Mount Prindle and Lime Peak plutonic areas.

Figures 31,32 , and 33 show the generalized geology of the Table Mountain, Circle mining district, and Chena Hot Springs areas with the group classification of the drainage basins indicated. In the Table Mountain area (fig. 31), samples from both the northeast and southwest clusters of felsic dikes were classified as belonging to both groups. Only one sample in the southwest area scored above the group 1 mean. Three samples from the northeast dike cluster and one sample from the southwest dike cluster showed discriminant function

Table 8.--Results of classification of samples from the Lime Peak and Mount Prindle areas. Most (98.55\%) of the cases were correctly classified

\begin{tabular}{lccc}
\hline $\begin{array}{l}\text { Actual } \\
\text { group }\end{array}$ & $\begin{array}{c}\text { Number } \\
\text { of cases }\end{array}$ & \multicolumn{2}{c}{$\begin{array}{c}\text { Predicted group } \\
\text { membership }\end{array}$} \\
\cline { 3 - 4 } & & Group 1 & Group 2 \\
\hline \multirow{2}{*}{1} & 32 & 31 & 1 \\
& & $96.9 \%$ & $3.1 \%$ \\
2 & 37 & 0 & 37 \\
& & $0.0 \%$ & $100.0 \%$ \\
\hline
\end{tabular}




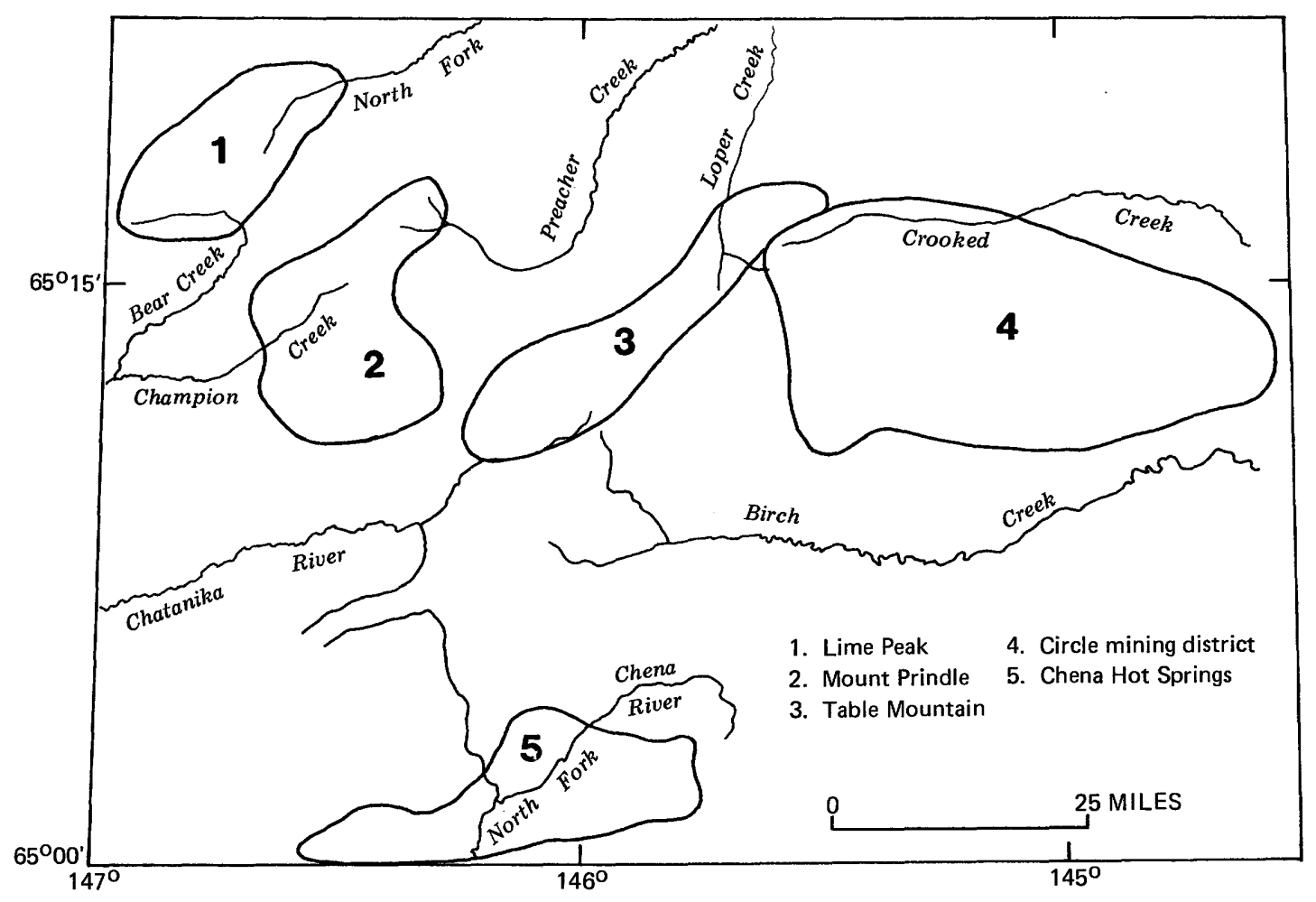

Figure 30.--Location and approximate boundaries of areas included in study.

scores more negative than the group 2 mean. Discriminant scores of stream-sediment samples from the northern part of the pluton in the Circle mining district (fig. 32) are similar to the Lime Peak samples. Basins in the western part of the area drain metamorphic rocks that overlie the granite; samples from these basins, characterized by discriminant scores below the group 2 mean, were classified as belonging to group 2 , indicating a strong similarity to the Mount Prindle area. Drainage basins near the eastern and western margins of the pluton near Chena Hot Springs (fig. 33 ), with two samples scoring above the group 1 mean, are classified as belonging to group 1 . Samples from the central part of the pluton are classified as group 2 .

Discriminant analysis requires that samples be classified as part of a known group. In the present study, samples from the Table Mountain, Circle mining district, and Chena Hot Springs areas were classified as being similar to either Lime Peak (a tin-bearing area) or to Mount Prindle (a uraniumbearing area). No provision was made for barren areas. In order to test how samples from barren areas would be classified, discriminant scores were calculated for 16 stream-sediment samples from an area about $16 \mathrm{~km}$ northeast of the Lime Peak and Mount Prindle areas. There, the basins drain barren metamorphic rocks, and no plutonic rocks crop out. All samples were classified as belonging to group 2, or uranium favorable. All samples but one scored less negative than the group 2 mean.

Application of discriminant function analysis to samples from areas with known tin (Lime Peak) and uranium (Mount Prindle) occurrences indicates that such areas may be discriminated based on their concentrations of $\mathrm{V}, \mathrm{Zn}, \mathrm{Y}, \mathrm{Sc}$ and $\mathrm{Nb}$ in streamsediment samples. Application of the discriminant function to samples from the three areas intruded by plutons similar in composition to those in the Lime Peak and Mount Prindle indicate that all areas contain samples similar to samples from the tinbearing Lime Peak and uranium-bearing Mount Prindle areas. In the western part of the Circle mining district, most samples were classified as belonging to group 2, indicating that this district may have uranium potential. Alternatively, the results show that there may simply be barren areas in this district, and the resulting analyses were forced into group 2 by the fact that the discriminant function was constructed with data from only two groups.

\section{REFERENCES CITED}

Barker, J. C., and Clautice, K. H., 1977, Anomalous uranium concentrations in artesian springs and stream sediments in the Mount Prindle area, Alaska: U. S. Bureau of Mines Open-file Report 130-77, $18 \mathrm{p}$. 

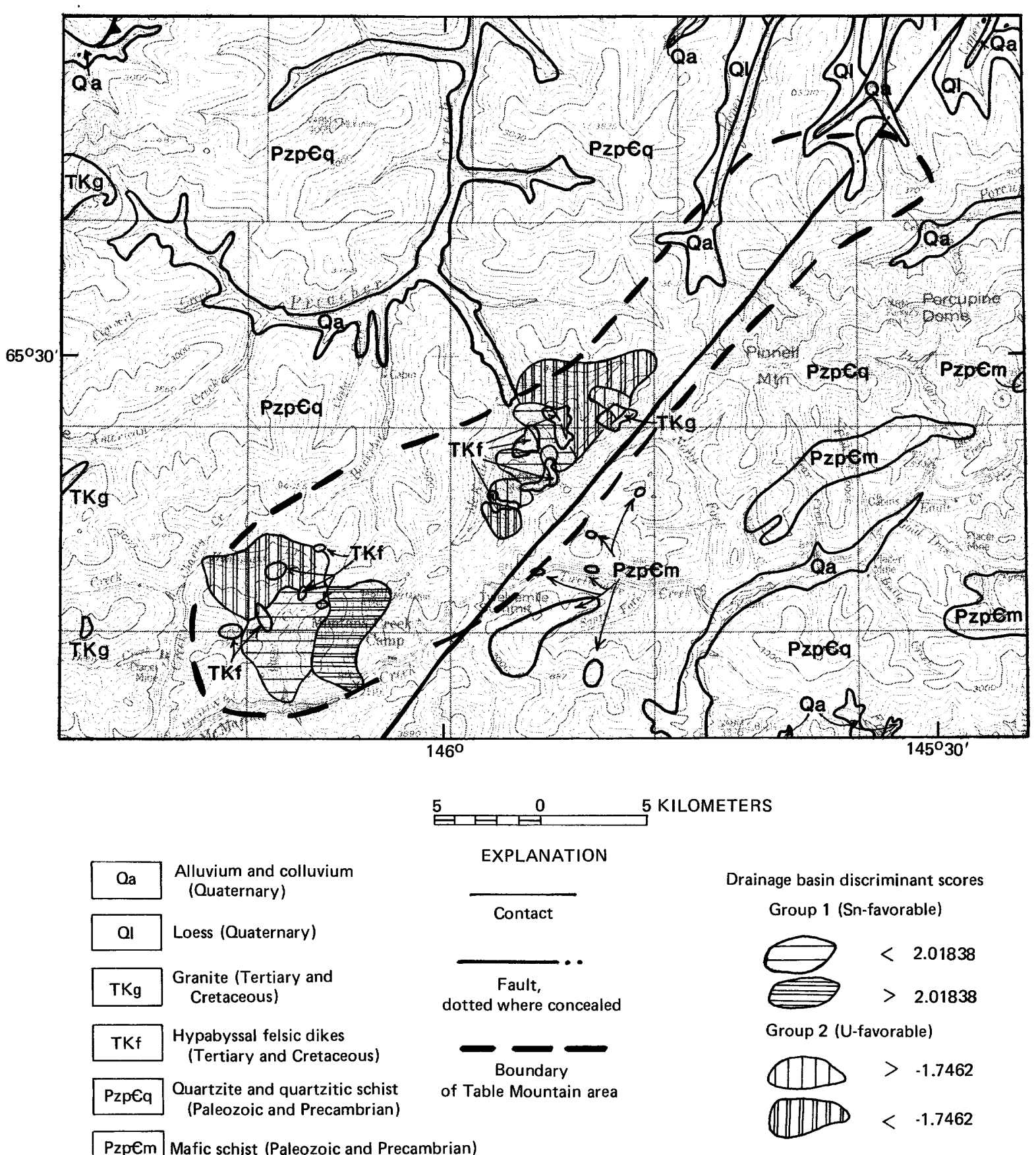

Pzpem Mafic schist (Paleozoic and Precambrian)

Figure 31.--Generalized geology of the Table Mountain area and classification of some of the drainage basins based on their discriminant scores (after Menzie and others, 1983). 

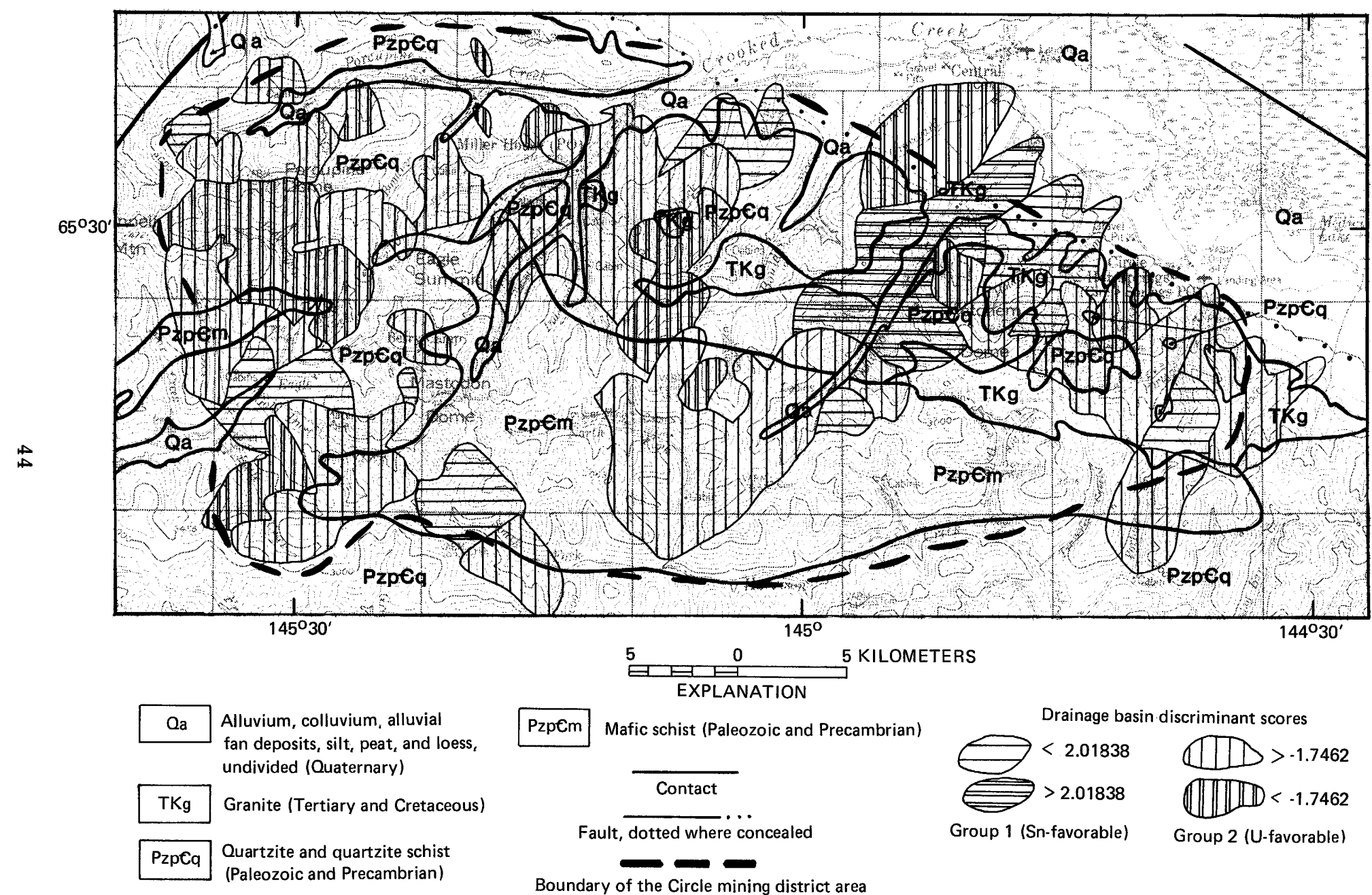

Pzpem Mafic schist (Paleozoic and Precambrian)

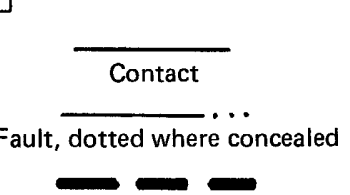

Drainage basin discriminant scores

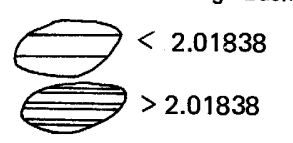

UIID $>-1.7462$ UIIID $<-1.7462$

Group 1 (Sn-favorable)

Group 2 (U-favorable)

Boundary of the Circle mining district area

Figure 32.--Generalized geology of the Circle mining district area and classification of the drainage basins based on their discriminant scores (after Menzie and others, 1983). 


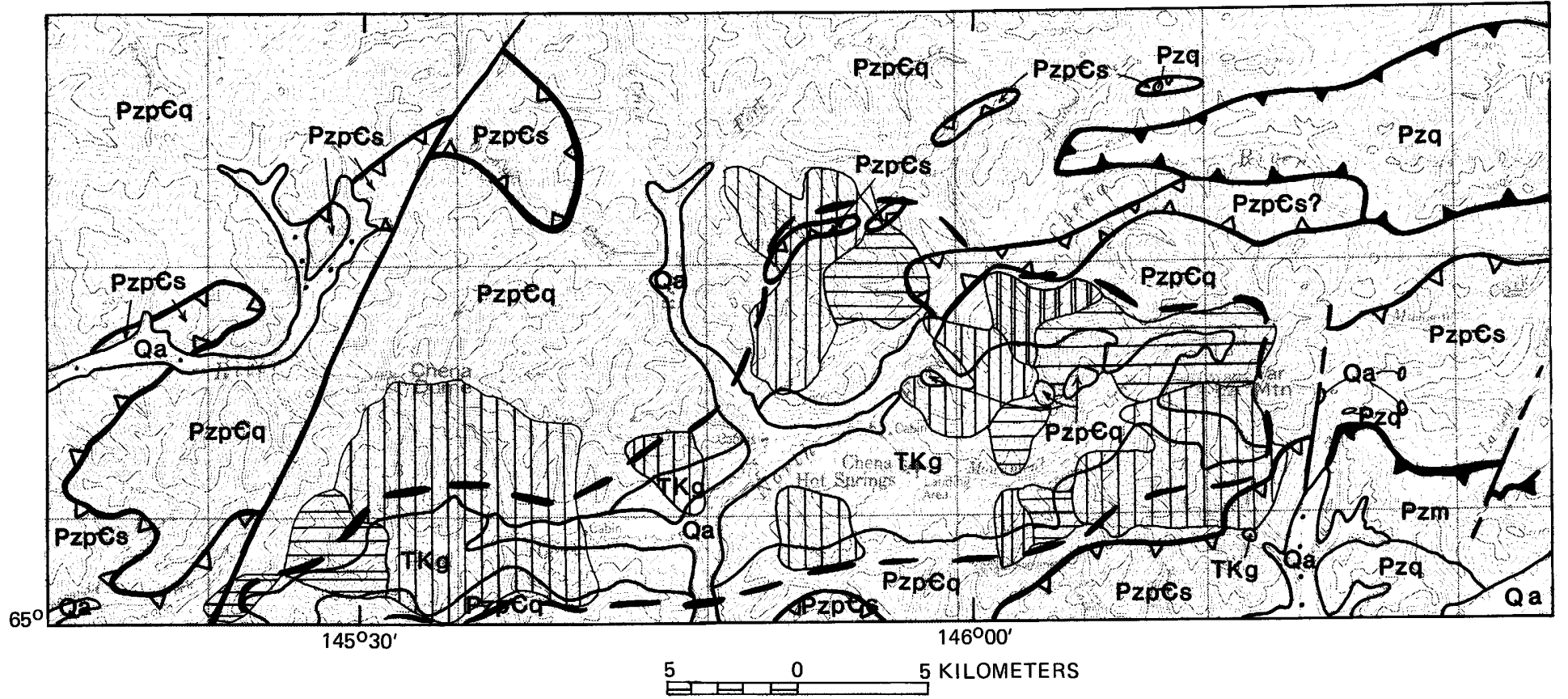

EXPLANATION
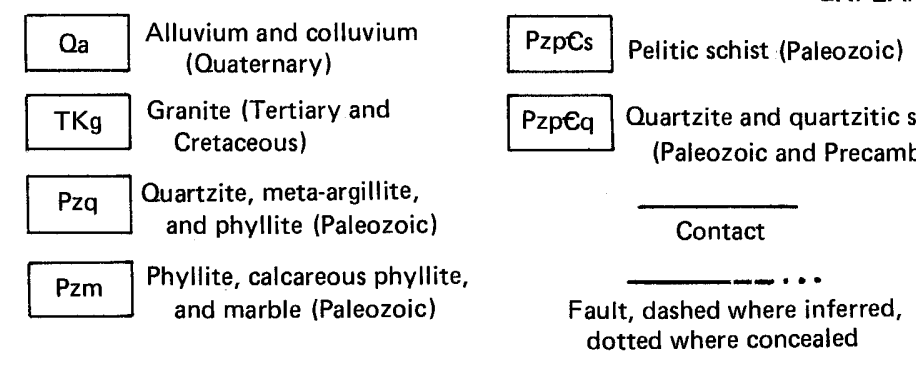

$\Lambda \Delta$

Thrust fault,

sawteeth on upper plate

$$
\triangle \triangle \triangle
$$

Pre-metamorphic thrust fault, postulated

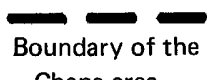

Boundary of the Chena area
Drainage basin discriminant scores

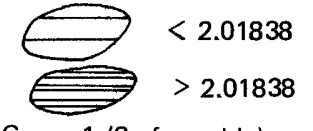

Group 1 (Sn-favorable)

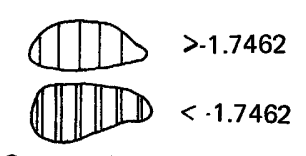

Group 2 (U-favorable)

Figure 33.-Generalized geology of the Chena Hot Springs area and the classification of drainage basins based on their discriminant scores (after Menzie and others, 1983). 
Grimes, D. J., and Marranzino, A. P., 1968, Directcurrent arc and alternating-current spark emission spectrographic field methods for the semiquantitative analyses of geologic materials: U.S. Geological Survey Circular 591,6 p.

Klecka, W. R., 1975, Discriminant analysis, in Nie, N. H., Hull, C. H., Jenkins, J. G., Steinbrennere, Karin, and Bent, D. H., Statistical Package for the Social Sciences (2d ed.): McGraw-Hill Book Company, p. 434-467.

Menzie, W. D., Foster, H. L., Tripp, R. B., and Yeend, W. E., 1983, Mineral resource assessment of the Circle Quadrangle, Alaska: U.S. Geological Survey Open-File Report 83170-B, $57 \mathrm{p}$.

Rose, A. W., Hawkes, H. E., and Webb, J. S., 1979, Geochemistry in Mineral Exploration (2d ed.): New York, Academic Press, 655 p.

Reviewers: R. D. Koch and D. A. Singer

\section{DISTRIBUTION AND CHARACTER OF THE PERIDOTTTE-LAYERED GABBRO COMPLEX OF THE SOUTHEASTERN YUKON-KOYUKUK OPHIOLTE BELT}

\section{by Robert A. Loney and Glen R. Himmelberg ${ }^{1}$}

The Yukon-Koyukuk ophiolite belt is discontinuously exposed for more than $900 \mathrm{~km}$ along the north and southeast margins of the Yukon-Koyukuk basin (fig. 34). The part of the ophiolite studied forms a nearly continuous outcrop $100 \mathrm{~km}$ long and $1-10 \mathrm{~km}$ wide on the southeast margin of the basin (fig. 35). Although in this area in places the belt is offset and interrupted by crossfaulting and folding, it contains the best and most continuous outcrops of the peridotite-layered gabbro complex in the

${ }^{1}$ U.S. Geological Survey and University of Missouri, Colombia, MO 65211

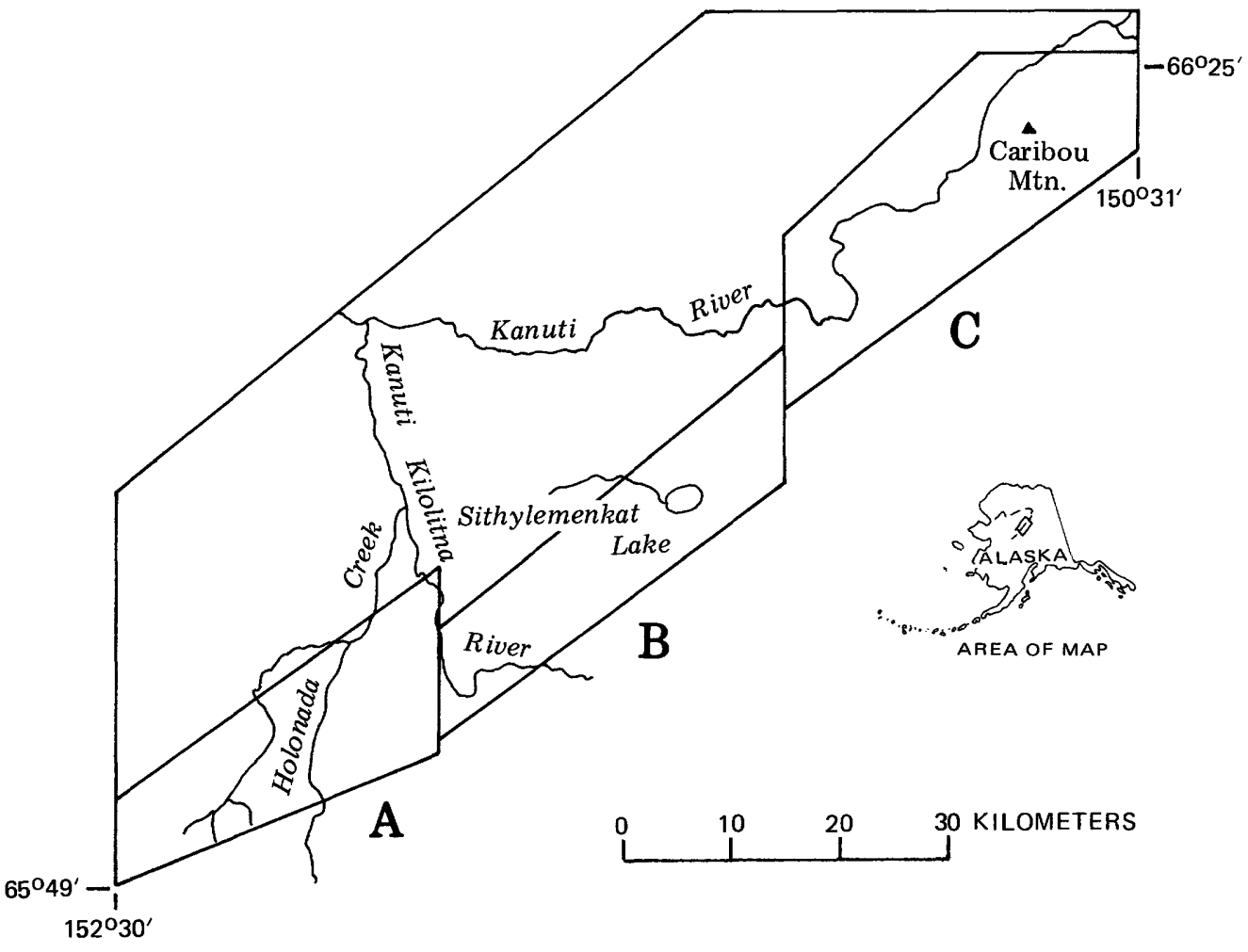

Figure 34.--Index map showing location of the southeastern Yukon-Koyukuk ophiolite belt and of the map segments (A, B, C) shown in figure 35. Inset map shows location of area (rectangle) and margins of Yukon-Koyukuk basin (heavy dashed line). 


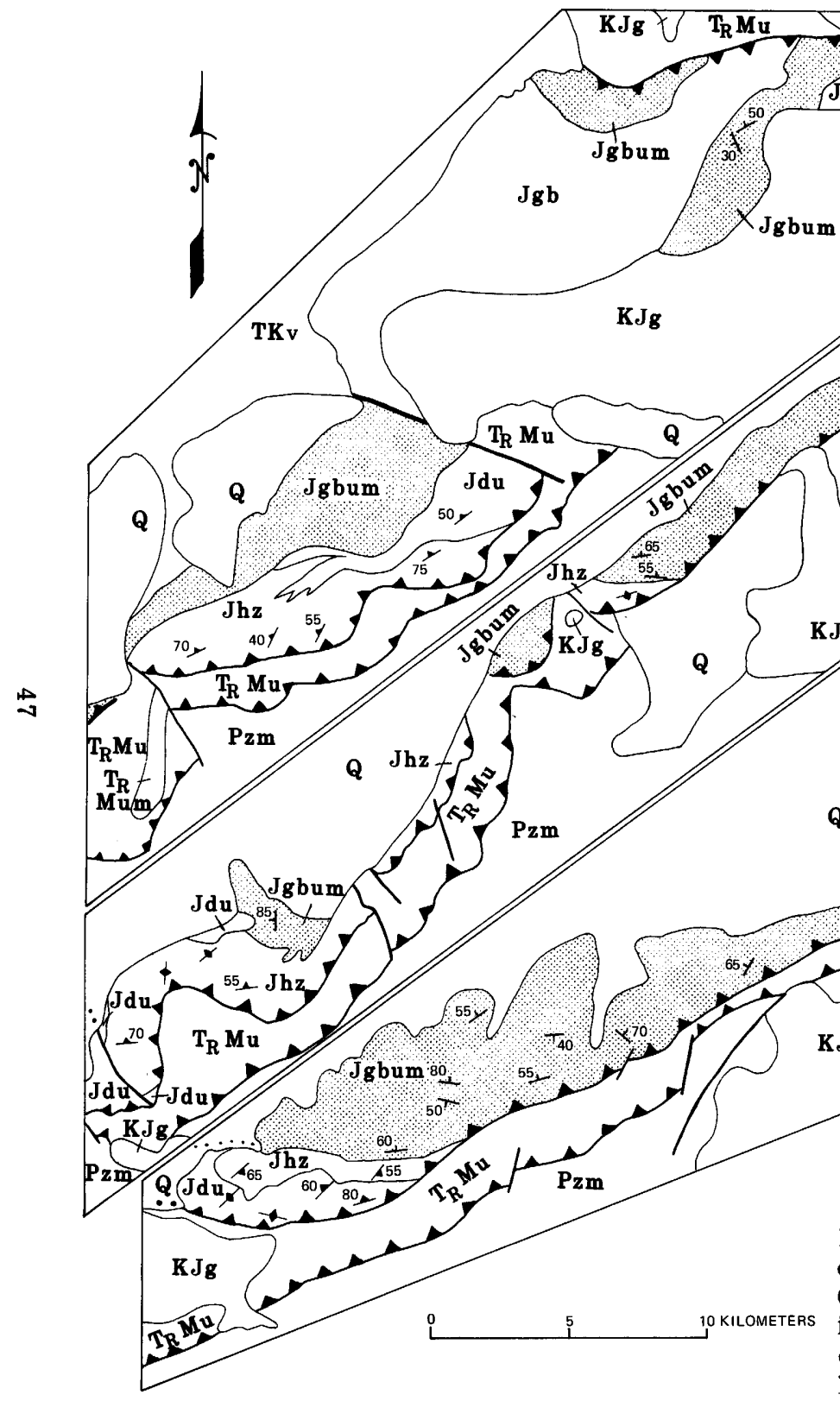

\section{EXPLANATION}

Q Surficial deposits (Quaternary)

TKv Felsic volcanic rocks (Tertiary and Cretaceous)

KJg Granitic rocks (Cretaceous and Jurassic)

Peridotite - layered gabbro complex (Jurassic?) -- consists of

Jhz Harzburgite

Jdu

gbum Cumulus gabbro Cumulus and ultramafic rocks plutonic suite

Jgb Massive gabbro

$\mathrm{T}_{\mathrm{R}} \mathrm{Mu}$ Mafic volcanic and intrusive rocks, chert, and mudstone, undivided (Triassic to Mississippian)

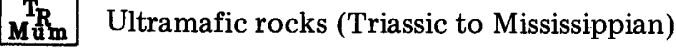

Pzm Metamorphic rocks (lower Paleozoic)

- -... Contact -- dotted where concealed

-... Fault -- dotted where concealed

^... Thrust fault -- dotted where concealed. Sawteeth on upper plate

+50 Strike and dip of cumulus layering in unit Jgbum

Strike and dip of foliation $\mathbf{A}$ in harzburgite and dunite
Inclined
70ertical

Figure 35.--Generalized geologic maps of the southeastern Yukon-Koyukuk ophiolite belt: see figure 34 for locations of segments A, B, and C. Geologic mapping shown in areas not part of the peridotite-gabbro complex is compiled from Patton and Miller (1970, 1973), and unpublished compilations (1983) by W. W. Patton, Jr., C. Carlson, J. H. Dover, R.A. Loney, and G. R. Himmelberg. 
Yukon-Koyukuk ophiolite belt. According to Patton and Miller (1973), the ophiolite belt is thrust to the southeast over metamorphic units (schist and quartzite) of early Paleozoic age. (See also Patton and others, 1977). Our present work supports this concept.

In detail, the ophiolite belt is composed of two units that strike generally northeast and are bounded on the southeast by faults that dip generally northwest (fig. 35). One unit is structurally lower, of Mississippian to Triassic age, and crops out generally to the southeast. It is composed predominantly of pillow basalt, diabase, ultramafic rock, and radiolarian chert (that is, the basalt-chert unit) that is in fault contact on the southeast with older metamorphic units. The other unit is structurally higher, of Jurassic(?) age, and crops out generally to the northwest; it is composed of the peridotite-layered gabbro complex (Patton and others, 1977) that is in fault contact with the basalt-chert unit.

The contact between the peridotite-layered gabbro complex and the basalt-chert unit has a variable attitude, but generally dips northwestward beneath the complex. Field relations strongly indicate that the contact is a thrust fault. In some places, the dip of the contact seems steep, but in several well-exposed localities, measured dips range from $15^{\circ}$ to $26^{\circ} \mathrm{NW}$. (fig. 35). The contact cuts different parts of the peridotite-layered gabbro complex, and is commonly marked by a thin, discontinuous layer of garnet amphibolite. The garnet amphibolite was probably derived from mafic igneous rock situated beneath the previously hot thrust sheet located at a deeper level in the crust.

The peridotite-layered gabbro complex can be subdivided into a cumulus plutonic suite and a tectonite mantle suite that have consistent spatial relations throughout this segment of the YukonKoyukuk ophiolite belt. That is, the plutonic suite lies consistently along the northwest contact of the mantle suite (fig. 35) and is composed of interlayered cumulus wehrlite, olivine clinopyroxenite, and gabbro, which are generally not exposed sufficiently to define mappable subunits. The mantle suite consists of two mappable subunits: (1) a dunite subunit, composed of dunite and minor pyroxenite, and (2) a harzburgite subunit, composed of harzburgite and minor dunite. The two subunits intertongue and either unit may dominate locally, with harzburgite being slightly more abundant overall. In the outcrop belt of the mantle suite, neither the harzburgite nor dunite subunits occupies a consistent position in the belt, and either subunit may be in contact with the cumulus plutonic suite at any given locality (fig. 35).

In conclusion, the evidence for the thrust nature of the contact between the peridotite- layered gabbro complex and the basalt-chert unit may be summarized as follows:

(1) Where observed, the contact is a shear zone.

(2) The peridotite-layered gabbro complex is structurally (and generally topographically) high$\mathrm{er}$, with the basalt-chert unit dipping beneath it.

(3) The high-temperature contact zone does not extend into the basalt-chert unit.

(4) Cross-cutting of the structural grain of the peridotite-layered gabbro complex by the contact results in juxtaposition of both cumulus plutonic and tectonite mantle suites with the basalt-chert unit.

In contrast, the contact between the cumulus plutonic suite and the tectonite mantle suite is probably a normal cumulus igneous contact. Within the peridotite-layered gabbro thrust sheet, the persistence of the plutonic suite along the northwest contact of the mantle suite and the lack of parallelism of this contact with the thrust faults suggests that the contact is not a thrust fault. The cumulus layering in the plutonic suite generally strikes parallel to the contact, whereas the foliation attitudes in the mantle suite are commonly discordant to it. This relation suggests cumulus igneous sedimentation on a previously deformed terrane.

Such structural complexities as folding of the peridotite-layered gabbro complex thrust sheet could account for the northwestward reentrant of the thrust near the Kanuti Kilolitna River near the southwestern end of map strip B and the repetition of the thrust in the Caribou Mountain area at the northeastern end of map strip $C$ (figs. 34,35 ).

\section{REFERENCES CITED}

Patton, W. W., Jr., and Miller, T. P., 1970, Preliminary geologic investigations in the Kanuti River Region, Alaska: U.S. Geological Survey Bulletin 1312-J, p. J1-J10.

Patton, W. W., Jr., and Miller, T. P., 1973, Bedrock geologic map of Bettles and southern part of Wiseman Quadrangle, Alaska: U.S. Geological Survey Miscellaneous Field Studies Map MF-492, 1 sheet, scale 1:250,000.

Patton, W. W., Jr., Tailleur, I. L., Brosge, W. P., and Lanphere, M. A., 1977, Preliminary report on the ophiolites of northern and western Alaska, in Coleman, R. G., and Irwin, W. P., eds., North American Ophiolites: State of Oregon Department of Geology and Mineral Industries Bulletin 95, p. 51-57.

Reviewed by W. W. Patton, Jr., and A. B. Ford 


\section{SOUTHWESTERN ALASKA}

(Figure 36 shows study areas deseribed.)

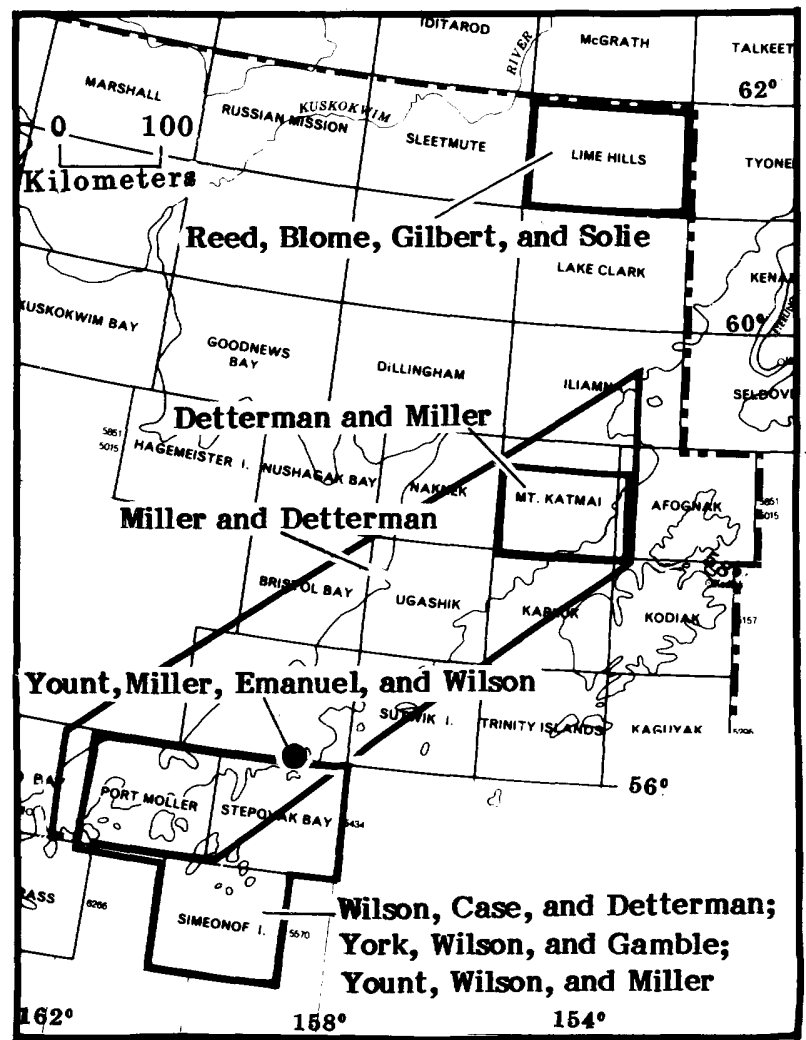

Figure 36.--Areas in southwestern Alaska discussed in this circular. Outlines define the areas described by the indicated authors.

\section{KAGUY AK FORM ATION- AN UPPER CRETACEOUS FLYSCH DEPOSIT}

\section{by Robert L. Detterman and John W. Miller}

The Kaguyak Formation was established by Keller and Reiser (1959) for a sequence of Late Cretaceous (Campanian and Maestrichtian) rocks exposed along the shore of Shelikof Strait near the abandoned village of Kaguyak, Katmai National Park (fig. 37). We revisited this sequence in 1983 as part of ongoing investigations in the Mount Katmai area and determined that it is part of a flysch sequence. We measured the rocks exposed in the cliffs between Big River and Swikshak River and the section at Kaguyak Point near the abandoned village of Kaguyak and collected fossils.

The measured section, $900 \mathrm{~m}$ thick (fig. 38), is a prograding submarine fan whose sediments were deposited into a trench fronting a Mesozoic magmatic arc. The section shown is not complete, as neither upper nor lower contact was located. However, Quaternary volcanic rocks overlie the section a short distance above the top of the measured interval, and the Herendeen Limestone (Early Cretaceous) underlies the Kaguyak Formation, cropping out on two small islets about $0.8 \mathrm{~km}$ southeast of Kaguyak Village. Approximately $100-150 \mathrm{~m}$ of additional section is present at the type locality.

The lower $450 \mathrm{~m}$ are composed of a marine basin sequence of massive dark siltstone and claystone with a few thin sand layers. This part of the section is mainly distal turbidites facies D of Walker and Mutti (1973). This part contains the ammonites Diplomoceras notabile Whiteaves, Didymoceras aff. D. hornbeyense (Whiteaves), Gaudryceras tenuiliratum Yabe, Neophylloceras ramosum (Meek), Pachydiscus (Pachydiscus) hazzardi Jones, and P. (Pachydiscus) kamishakensis Jones, and the pelecypods Inoceramus balticus var. I. kunimiensis Nagao and Matsumoto, and I. subundatus Meek. These fossils indicate that the rocks of the Kaguyak Formation can be assigned to the Pachydiscus kamishakensis zone of latest Campanian to early Maestrichtian age (Jones, 1963).

The marine basin sequence is overlain by about $170 \mathrm{~m}$ of interbedded, medium-bedded to massive, dark siltstone and sandstone with flute casts, drag marks, flame structures, dish structures, and, locally, convoluted beds. This is interpreted as a lower fan sequence of mainly $\mathrm{C}_{2}$ subfacies (Walker and Mutti, 1973). Flute casts, many as long as $1 \mathrm{~m}$, are particularly well developed in this interval; they indicate currents flowing S.-S. $30^{\circ} \mathrm{W}$.

The upper $260 \mathrm{~m}$ of section is a prograding middle to upper fan sequence; it has massive, lenti-

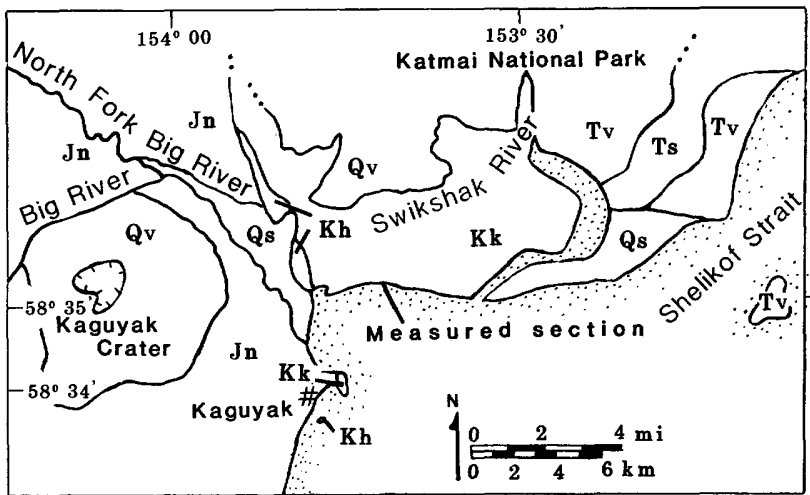

Figure 37.-Location of measured section and distribution of geologic units. Qs, surficial deposits (Quaternary); Qv, volcanic rocks (Quaternary); Ts, sedimentary rocks; Tv, volcanic rocks (Tertiary); Kk, Kagyuak Formation (Upper Cretaceous); Kh, Herendeen Limestone (Lower Cretaceous); Jn, Naknek Formation (Jurassic). 


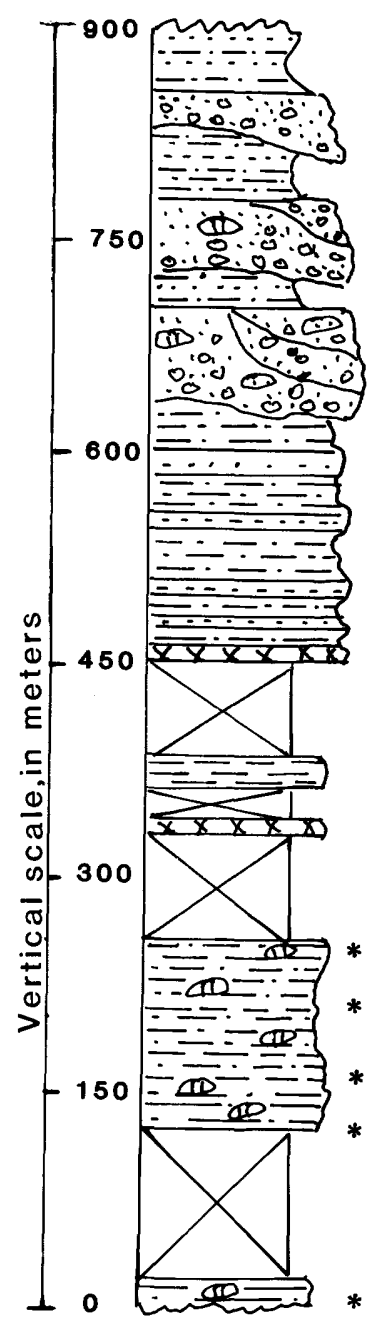

Figure 38.--Generalized type section of the Kaguyak Formation.

cular, fining upward, graded coarse- to fine-grained sandstone channels with thin interbeds of overbank siltstone. Rip-up clasts are common in the sandstone, and some units may represent debris flows. These beds are mainly facies B (Walker and Mutti, 1973).

The Kaguyak Formation is part of an extensive Upper Cretaceous flysch sequence in southern Alaska that includes the Kodiak, Shumagin, and Hoodoo Formations, as well as the Matanuska Formation and part of the Valdez Group. A significant part of all of these formations was deposited in a trench environment during Campanian and Maestrichtian time, suggesting a well-defined Mesozoic trench inboard of the present Aleutian trench. Rocks in all these stratigraphic units are similar in that they are composed of dark siltstone, shale, and graded sandstone beds and contain turbidite features. Their dissimilarities can be attributed to the distance of each from the source provenance at time of deposition. Lithologies of the Kaguyak, Hoodoo, and Matanuska Formations indicate that they were closest to the source area; post-depositional subduction of outboard units has undoubtedly decreased these distances. Nonmarine and nearshore shallow marine rocks coeval with the flysch deposits are present on the Alaska Peninsula in the Chignik Formation (Mancini and others, 1978) and in the Cook Inlet area (Magoon and others, 1980).

Fossils are not abundant in any of these rocks but are more common in the Kaguyak and Hoodoo Formations. Inoceramus kusiroensis Nagao and Matsumoto (Early Maestrichtian) is found in the Kaguyak Formation (Keller and Reiser, 1959, p. 277, and this report); it is also present in the Hoodoo (Detterman and others, 1981), Shumagin (Moore, 1973 , p. 597), and Kodiak Formations (Jones and Clark, 1973). Additionally, Inoceramus subundatus Meek, I. schmidti Michael, and Diplomoceras notabile whiteaves are found in the Hoodoo (Detterm an and others, 1981), Kaguyak (this report), and Matanuska Formations (Grantz and Jones, 1960, p. B349). These fossil associations in similar lithologies strongly suggest a common depositional environment for the formations in southern Alaska during Campanian and Maestrichtian time.

\section{REFERENCES CITED}

Detterman, R. L, Case, J. E., and Yount, M. E., 1981, Megafossil locality map, checklists, and stratigraphic sections of the Chignik and Sutwik Island Quadrangles, Alaska: U.S. Geological Survey Miscellaneous Field Studies Map MF-1053N, 2 sheets, scale $1: 250,000$.

Grantz, Arthur, and Jones, D. L., 1960, Stratigraphy and age of the Matanuska Formation, southcentral Alaska: U.S. Geological Survey Professional Paper 400-B, p. B347-B350.

Jones, D. L., 1963, Upper Cretaceous (Campanian and Maestrichtian) ammonites from southern Alaska: U.S. Geological Survey Professional Paper 432, $53 \mathrm{p}$.

Jones, D. L., and Clark, S. H. B., 1973, Upper Cretaceous (Maestrichtian) fossils from the Kenai-Chugach Mountains, Kodiak, and Shumagin Islands, southern Alaska: U.S. Geological Survey Journal of Research, v. 1, no. 2, p. 125-136.

Keller, A. S., and Reiser, H. N., 1959, Geology of the Mount Katmai area, Alaska: U.S. Geological Survey Bulletin 1058-G, p. G273-G278.

Magoon, L. B., Griesbach, F. B., and Egbert, R. M., 1980, Nonmarine Upper Cretaceous rock, Cook Inlet, Alaska: American Association of 
Petroleum Geologists Bulletin, v. 64, no. 8, p. 1260-1266.

Mancini, E. A., Deeter, T. M., and Wingate, F. H., 1978, Upper Cretaceous arc-trench gap sedimentation on the Alaska Peninsula: Geology, v. 6, p. 437-439.

Moore, J. C., 1973, Cretaceous continental margin sedimentation, southwestern Alaska: Geological Society of America Bulletin, v. 84, p. 595-614.

Walker, R. G., and Mutti, E., 1973, Turbidite facies and facies associations, in Middleton, G. V., and Bouma, A. H., eds., Turbidites and deep water sedimentation: Society of Economic Paleontologists and Mineralogists, Pacific Section, Syllabus, p. 119-158.

Reviewers: L. B. Magoon, III, and N. R. D. Albert

\section{THE BUCHIA ZONES IN UPPER JURASSIC ROCKS ON THE ALASKA PENINSULA}

\section{by John W. Miller and Robert L. Detterman}

Fossil pelecypods of the genus Buchia are abundant in Upper Jurassic and Lower Cretaceous strata in Alaska and are reliable index fossils for these ages. Based on many collections from recently measured sections on the Alaska Peninsula, a range zonation of index species for beds of Late Jurassic age (Oxfordian through Tithonian) has been developed (fig. 39). Lower Cretaceous Buchiabearing strata have not been studied in comparable detail.

Buchia was an attached epifaunal bivalve that lived in great numbers in western North America and eastern Asia. It seems to have preferred a shallow water, high-energy environment with a hard, sandy substrate, although some species lived in somewhat quieter, finer grained sedimentary environments. The Buchia shell is generally inequilateral and gently to highly convex and has a prominent beak on the large, left valve (table 9). Concentric ribs or radial striae (or both) cover the surface. The morphological variations in a single Buchia population have produced many species names. Imlay (1959) recognized that many of these nominal species could be amalgamated and also suggested a provisional stratigraphic succession for Buchia. Buchia zones have been studied in detail in northwestern California by Jones, Bailey, and Imlay (1969) and have been found to be useful in studies of Upper Jurassic and Lower Cretaceous rocks of California and Oregon.

Jeletsky (1965), in his study of extensive fossil collections from Upper Jurassic and Lower Cretaceous rocks of western Canada, found that Buchia was a useful zonal index fossil and proposed several provisional zones for rocks in that region.

The earliest known Buchia in Alaska, Buchia concentrica (Sowerby), is of Oxfordian age. In the
Cook Inlet area, this species occurs with the Late Jurassic ammonite Cardioceras in the lower part of the Snug Harbor Siltstone Member of the Naknek Formation (Detterman and Hartsock, 1966, p. 5153). Cardioceras is found worldwide in Upper Jurassic rocks; it ranges in age from Early Oxfordian to the early part of the Late Oxfordian. The association of Cardioceras with Buchia concentrica is useful in establishing a base for zonation of all Buchia and for use in stratigraphic and structural geologic studies in Upper Jurassic and Lower Cretaceous rocks of this region (fig. 39 , table 9 ).

On the Alaska Peninsula, Buchia concentrica is generally found in dark siltstone and shale directly overlying a thick nonmarine sandstone and conglomerate sequence. The fossils occur in sandy horizons or thin limestone layers and occur vertically through a few tens of meters to as many as $300 \mathrm{~m}$ of section.

Buchia rugosa occurs with B. concentrica through several tens of meters of primarily finegrained clastic rocks that contain slightly more sandstone and limestone than is typical of the B.

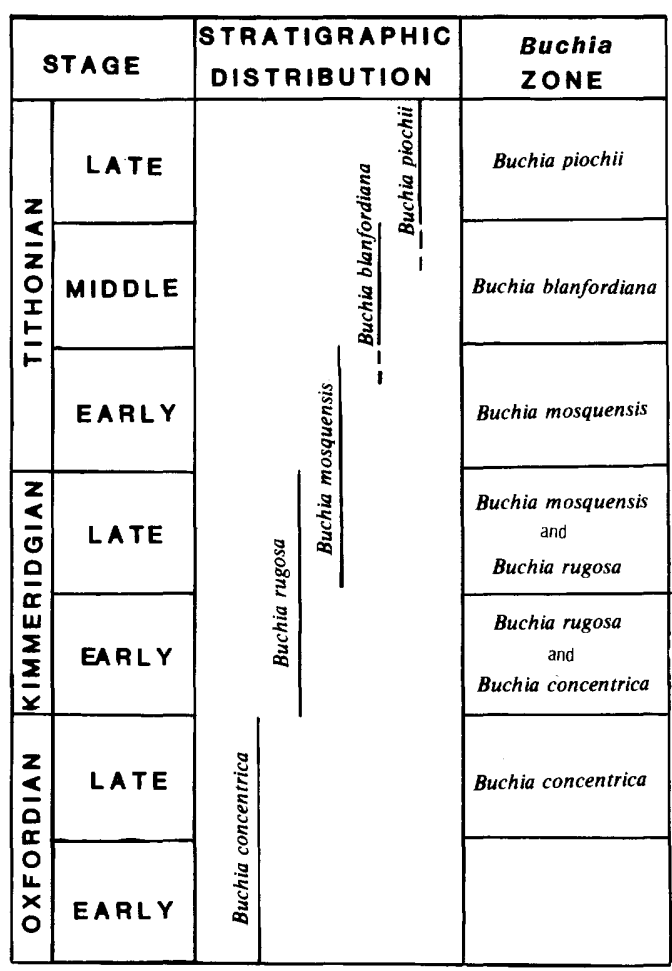

Figure 39.--Late Jurassic Buchia zones and stratigraphic distribution of species on the Alaska Peninsula. 
Table 9.--Species of the pelecypod Buchia of Late Jurassic age on the Alaska Peninsula

\begin{tabular}{|c|c|c|}
\hline Buchia species & Age & Distinctive characteristics \\
\hline Buchia piochii (Gabb) & $\begin{array}{l}\text { Middle to } \\
\text { late Tithonian }\end{array}$ & $\begin{array}{l}\text { Small, moderately } \\
\text { convex left valve } \\
\text { with long, incurved beak. } \\
\text { Low, irregularly } \\
\text { spaced ribs. No striae. }\end{array}$ \\
\hline Buchia blandfordiana (Stolczka) & $\begin{array}{l}\text { Middle } \\
\text { Ti thon i an }\end{array}$ & $\begin{array}{l}\text { Large, thick, } \\
\text { inequivalved. } \\
\text { Moderately convex left } \\
\text { valve, widely } \\
\text { spaced ribs. }\end{array}$ \\
\hline Buchia mosquens is (von Buch) & $\begin{array}{l}\text { Late Kimmerid- } \\
\text { gian to early } \\
\text { Tithonian }\end{array}$ & $\begin{array}{l}\text { Medium, inequivalved. } \\
\text { Strongly convex, left } \\
\text { valve wi th incurved } \\
\text { beak and low irregularly } \\
\text { spaced ribs. Scattered } \\
\text { striae when evident. }\end{array}$ \\
\hline Buchia rugosa (Fischer) & Kimmer i dg i an & $\begin{array}{l}\text { Medium, inequivalved. } \\
\text { Moderately convex left } \\
\text { valve. Very fine, dense } \\
\text { striae. }\end{array}$ \\
\hline Buchia concentrica (Sowerby) & $\begin{array}{l}\text { Late Oxfordian } \\
\text { to early } \\
\text { Kimmeridgian }\end{array}$ & $\begin{array}{l}\text { Medium to large, nearly } \\
\text { equivalved. Compressed. } \\
\text { Sharp, regular ribs. } \\
\text { Fine, dense striae. }\end{array}$ \\
\hline
\end{tabular}

concentrica zone. Sandstone becomes increasingly more abundant upward as Buchia mosquensis replaces B. concentrica. The younger species is associated with B. rugosa through as much as $300 \mathrm{~m}$ of predominantly thin, fine-grained sandstone and extends beyond the uppermost occurrence of B. rugosa through 200-400 $\mathrm{m}$ of sandstone containing thin pebble beds indicative of a shallow water, nearshore environment.

In a measured section on Indecision Creek in the Karluk Quadrangle, Buchia mosquensis was found in association with possible $\overline{\text { B. blanfordiana }}$ through about $20 \mathrm{~m}$ of interbedded thin sandstone and siltstone. Typically, these two species are not found together, and this occurrence may indicate a minor erosional or non-depositional hiatus in most sections. Sandstone beds at this horizon commonly show low-angle planar cross-stratification typical of a shoreface environment. At this horizon, the contact between the Naknek and the Staniukovich Formation has been established.

B. blanfordiana, alone characterizing the next younger zone, has been collected through as much as $240 \mathrm{~m}$ of predominantly sandstone section in the Ugashik Quadrangle. Elsewhere, due to preLate Cretaceous erosion, it may be found in a thinner section or may be missing.

B. piochii is found through a few tens of meters of sandstone in the Port Moller area. It is missing elsewhere on the Alaska Peninsula because of either pre-Late Cretaceous erosion or nondeposition.

Collections of the Early Cretaceous Buchia uncitoides, B. okensis (Berriasian), and B. crassicollis solida (Valanginian) have been made in the Port Moller area. These have been illustrated, and a preliminary zonation has been suggested (Miller and Jones, 1981), but we have not investigated these rocks in enough detail to define faunal zones.

\section{REFERENCES CITED}

Detterman, R. L., and Hartsock, J. K., 1966, Geology of the Iniskin-Tuxedni region, Alaska: U.S. Geological Survey Professional Paper 512, 78 p.

Imlay, R. W., 1959, Succession and speciation of the pelecypod Aucella (Buchia): U.S. Geological Survey Professional Paper 314-G, p. G155G169, pls. 16-19.

Jeletsky, J. A., 1965, Late Upper Jurassic and early Lower Cretaceous fossil zones of the Canadian western cordillera, British Columbia: Canada Geological Survey Bulletin 103, 70 p., pls. 1-22.

Jones, D. L., Bailey, E. H., and Imlay, R. W., 1969, Structural and stratigraphic significance of 
the Buchia zones in the Colyear SpringsPaskenta area, California: U.S. Geological Survey Professional Paper 647-A, p. A1-A23, pls. 1-5.

Miller, J. W., and Jones, D. L., 1981, A field guide to some common megafossils from postCallovian Mesozoic rocks of the Alaskan Peninsula: U.S. Geological Survey Open-File Report 81-745, 15 p., pls. 1-5, 1 table.

Reviewers: D. L. Jones and C. D. Blome

\section{JURASSIC RADIOLARIA FROM THE LIME HILLS QUADRANGLE}

\section{by Katherine M. Reed, Charles D. Blome, Wyatt G. Gilbert ${ }^{1}$, and Diana N. Solie ${ }^{2}$}

Fossil collections made during 1983 in the central part of the Lime Hills Quadrangle (fig. 40) have yielded Jurassic radiolarians. The samples were collected during a cooperative reconnaissance study by the Alaska Division of Geological and Geophysical Surveys and the U.S. Geological Survey.

Radiolarians were recovered from two of four samples taken from about $40 \mathrm{~m}$ of cutbank on the north side of the Swift River about $1.5 \mathrm{~km}$ southeast of benchmark Hat (sec. 12, T. 16 N., R. 33 W.) (fig. 40). The radiolarian fauna consists of Bagotum sp. aff. B. modestum Pessagno and Whalen (1982), Canutus sp. aff. C. izeensis Pessagno and Whalen, Canoptum annulatum Pessagno and Poisson (1981), and Droltus hecatensis Pessagno and Whalen, as well as Archaeodictyomitra sp. and Hsuum sp. This assemblage is of Early Jurassic (Pliensbachian) age.

The radiolarians occur in grey and greenish brown, laminated siliceous siltstone in beds averaging $3 \mathrm{~cm}$ thick separated by thin shaley partings. Fine-grained, obscurely planar-laminated sandstone and minor limy concretions are also present. The outcrop is similar in appearance to graptolitic Ordovician and Silurian siliceous sediments in the McGrath Quadrangle (Bundtzen and others, 1982; Bundtzen and Gilbert, 1983) and in the Lyman Hills in the northwest part of the Lime Hills Quadrangle (Gilbert, 1981).

The radiolarian-bearing siliceous siltstone possibly underlies volcanic conglomerate; the contact has not been mapped. Benchmark Hat is composed of volcanic conglomerate that contains abundant subangular mafic volcanic clasts $6-10 \mathrm{~cm}$ in diameter in a matrix of coarse-grained volcanic sandstone. The age of the conglomerate and the

1 Alaska Div. of Geological and Geophysical Surveys, Juneau AK 99801

Alaska Div. of Geological and Geophysical Surveys, Fairbanks, AK 99701 source of the volcanic clasts are not known.

The radiolarians are the first indication that marine Jurassic sedimentary rocks occur in this part of the upper Kuskokwim region. Late Triassic radiolarians are reported from the Cheeneetnuk River area (Gilbert, 1981), but the nearest known Jurassic sedimentary and volcanic rocks crop out along the Tatina River in the McGrath Quadrangle, about $120 \mathrm{~km}$ to the northeast (Reed and Nelson, 1980). There, Jurassic rocks are thought to overlie carbonate rocks of the Dillinger-Mystic succession of Gilbert and Bundtzen (1984) with an angular unconformity (Reed and others, 1979). The belt of Paleozoic carbonate rocks that contains this succession and shallow-water Paleozoic carbonate rocks of the Holitna Group crops out about $5 \mathrm{~km}$ northwest of benchmark Hat, and, as in the McGrath Quadrangle, Mesozoic rocks may lie unconformably on Paleozoic rocks.

\section{REFERENCES CITED}

Bundtzen, T. K., Kline, J. T., and Clough, J. G., 1982, Preliminary geology of the McGrath B-2 Quadrangle, Alaska: Alaska Division of Geological and Geophysical Surveys Open-File Report 149, 22 p., 1 sheet, scale 1:40,000.

Bundtzen, T. K., and Gilbert, W. G., 1983, Outline of geology and mineral resources of the Upper Kuskokwin region, Alaska: Journal of the Alaska Geological Society, v. 2, p. 101-117.

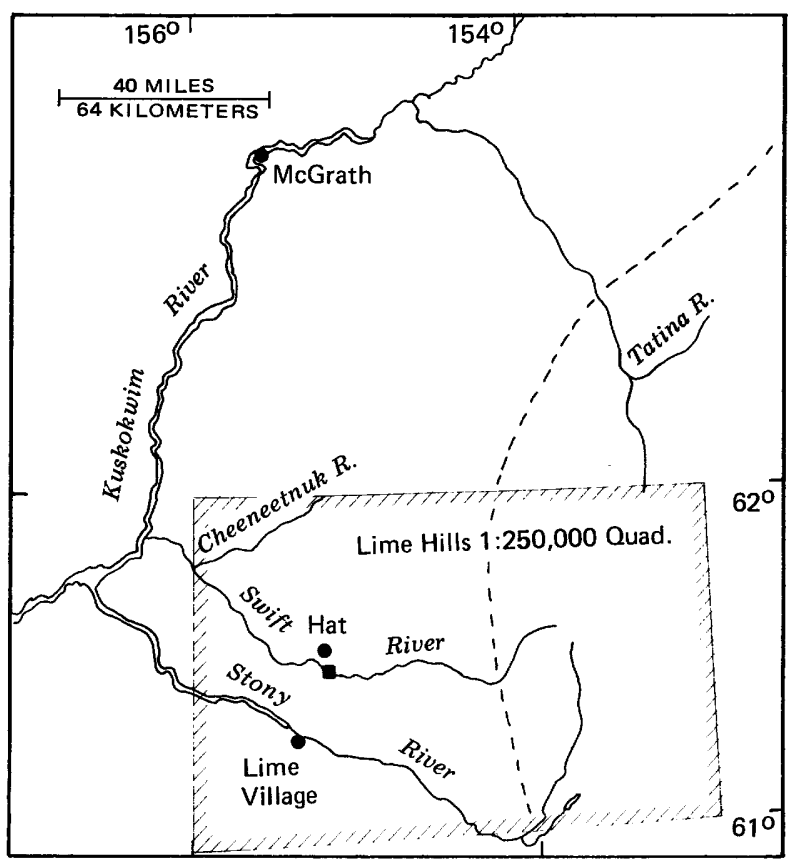

Figure 40.--Fossil locality $(x)$, main geographic features in the study area, and the boundary of the Lime Hills Quadrangle. 


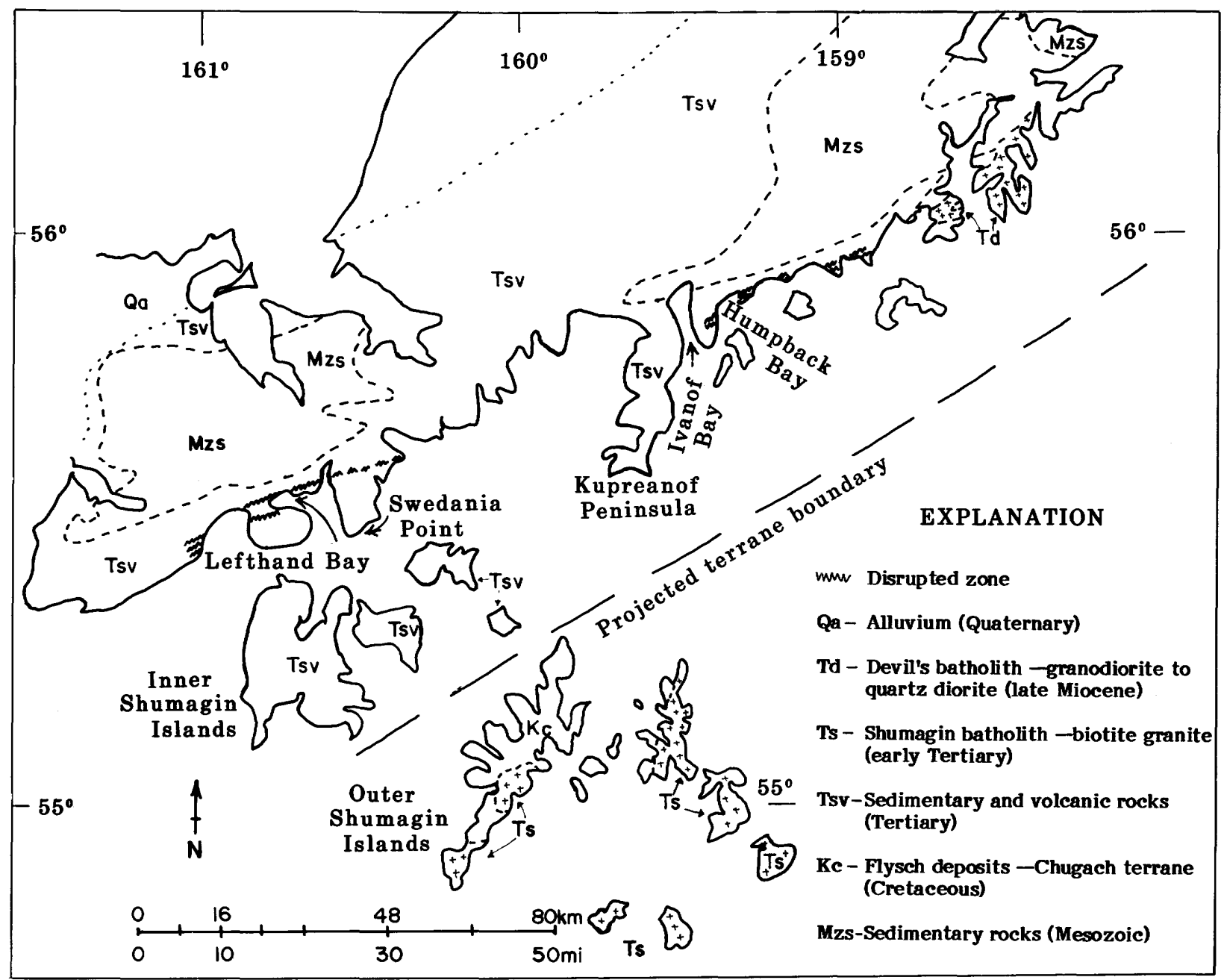

Figure 41.--Generalized geologic map showing extent of the structural discontinuity on the southern Alaska Peninsula.

Gilbert, W. G., 1981, Preliminary geologic map and geochemical data of the Cheeneetnuk River area, Alaska: Alaska Division of Geological and Geophysical Surveys Open-File Report 153, 10 p., 2 pls., scale 1:63,360.

Gilbert, W. G., and Bundtzen, T. K., 1984, Stratigraphic relationship between Dillinger and Mystic terranes, western Alaska Range, Alaska (abs.): Geological Society of America, Programs with Abstracts, v. 16, no. 4, p. 286.

Pessagno, E. A., Jr., and Poisson, Andre, 1981, Lower Jurassic Radiolaria from the Gümüslü allochthon of southwestern Turkey (Taurides Occidentales): Bulletin of the Mineral Research and Exploration Institute of Turkey, no. 92 (1979), p. 47-69.

Pessagno, E. A., Jr., and Whalen, P. A., 1982, Lower and Middle Jurassic Radiolaria (multicyrtid Nassellariina) from California, east-central
Oregon and the Queen Charlotte Islands, B.C.: Micropaleontology, v. 28, no. 2, p. 111169.

Reed, B. L., Curtin, G. C., Griscom, Andrew, Nelson, S. W., Singer, D. A., and Steele, W. C., 1979, The Alaskan Mineral Resource Assessment Program-Background information to accompany folio of geologic and mineral resource maps of the Talkeetna Quadrangle, Alaska: U.S. Geological Survey Circular 775, $17 \mathrm{p}$.

Reed, B. L., and Nelson, S. W., 1980, Geologic map of the Talkeetna Quadrangle, Alaska: U.S. Geological Survey Miscellaneous Investigations Series map I-1174, 15 p., 1 sheet, scale $1: 250,000$.

Reviewers: J. S. Kelley and B. L. Reed 


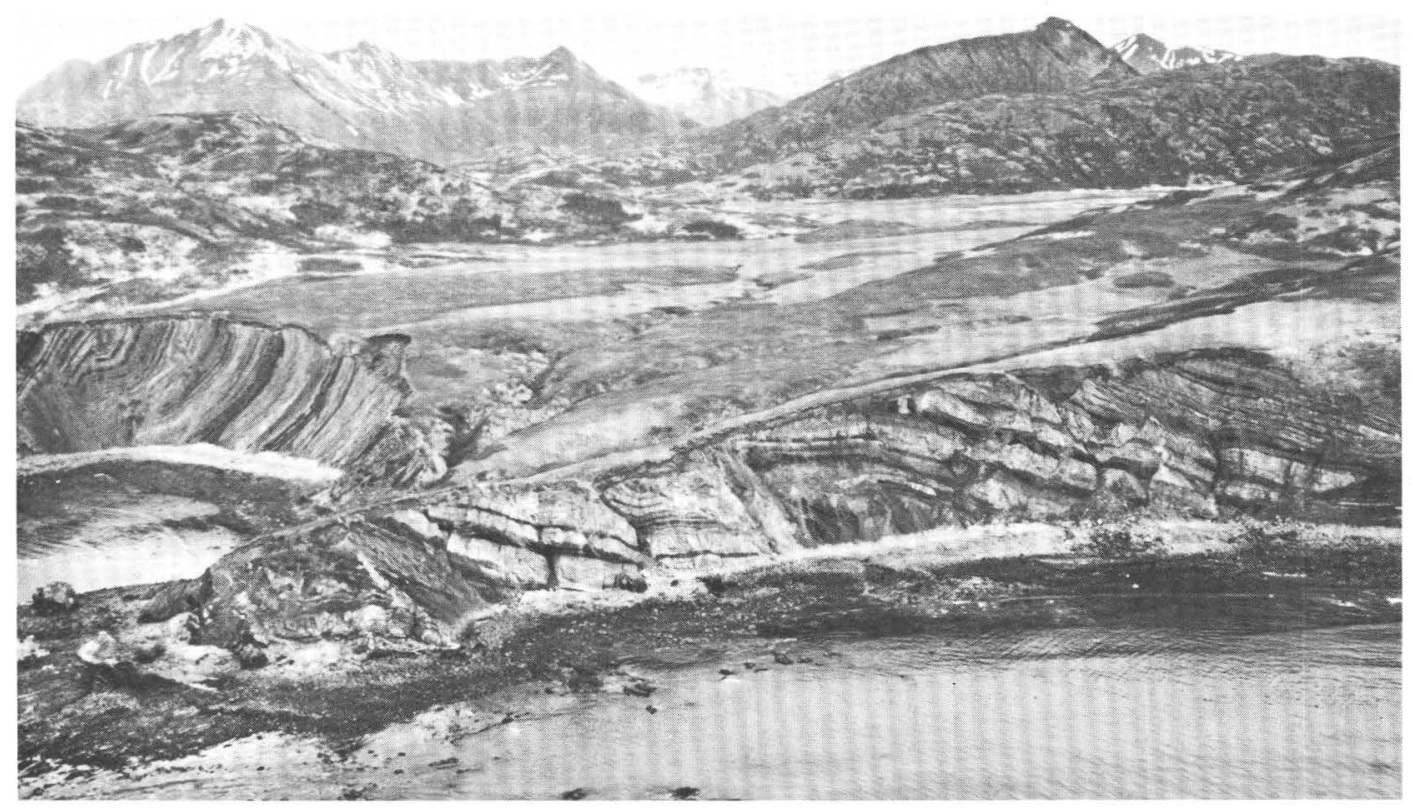

Figure 42.--Structurally disrupted zone northeast of the point on the east side of Hurnpback Bay; view to the west-northwest. White beds are approximately $3 \mathrm{~m}$ thick. Beds in the cove on the left side of the photograph strike and dip at almost $90^{\circ}$ to the beds in the foreground. Both lie within the disrupted zone.

\section{PRELIMINARY DESCRIPTION OF A MIOCENE ZONE OF STRUCTURAL COMPLEXITY, PORT MOLLER AND STEPOVAK BAY QUADRANGLES}

\section{by Frederic H. Wilson, James E. Case, and Robert L. Detterman}

A zone of structural disruption and complexity along the Pacific coast margin of the Alaska Peninsula (fig. 41) may be related to the Alaska Peninsula and the Chugach terrane boundary. The best exposure of this zone is located on the east shore of Humpback Bay (figs. 42, 43; also Burk, 1965, pl. 8, fig. 4); other exposures are located on the east side of Ivanof Bay, the north and south sides of Lefthand Bay, and in other coastal localities in the area. In some places, such as on the Kupreanof Peninsula, it is not recognized. This zone may extend discontinuously for $110-160 \mathrm{~km}$ along the coast; the width of the zone varies from 0.5 to $1 \mathrm{~km}$. Our current data and tentative interpretations are described here, pending completion of additional field research, laboratory, and office studies.

The zone is characterized by beds that dip as much as $80^{\circ}$ both NW and SE, closely spaced highangle faults, and tight, small-scale folds in Tertiary sedimentary and volcanic rocks. The zone parallels the regional structure of the Alaska Peninsula and lies near the projected boundary between the Alaska
Peninsula and the Chugach terrane (Moore and others, 1983). Stratigraphic units involved include the Oligocene Stepovak Formation of Burk (1965) and undifferentiated Tertiary volcanic rocks of possible Oligocene or Miocene age.

Burk (1965, p. 128-130) described a small part of this complex zone and discussed paleontological data supporting involvement of Oligocene and possibly Miocene rocks on the peninsula north of Swedania Point. According to Burk (1965, p. 128), the zone terminates against the Devils batholith (mid-Tertiary Kuiukta Bay batholith), a late Miocene granodiorite to quartz diorite pluton. An age of approximately $10 \mathrm{~m} . \mathrm{y}$. (Wilson and others, 1982) for that pluton provides a minimum age for the structural deformation. The clear involvement of Oligocene rocks provides a maximum age of deformation.

Mapping during 1983 indicates that, outboard or southeast of the zone, Oligocene and younger Tertiary rocks of the Inner Shumagin Islands dip gently (southeast and northwest) and are locally folded and faulted only slightly. To the southeast in the outer Shumagin Islands, Mesozoic rocks of the Chugach terrane are tightly folded along northeasttrending axes (Moore, 1974). Pervasive faulting of the Chugach terrane rocks was described by Moore (1974). He noted that faults can be traced only along topographic lineaments or at contacts with the earliest Tertiary Shumagin batholith. Deformation of Chugach terrane rocks is due partly to fold- 


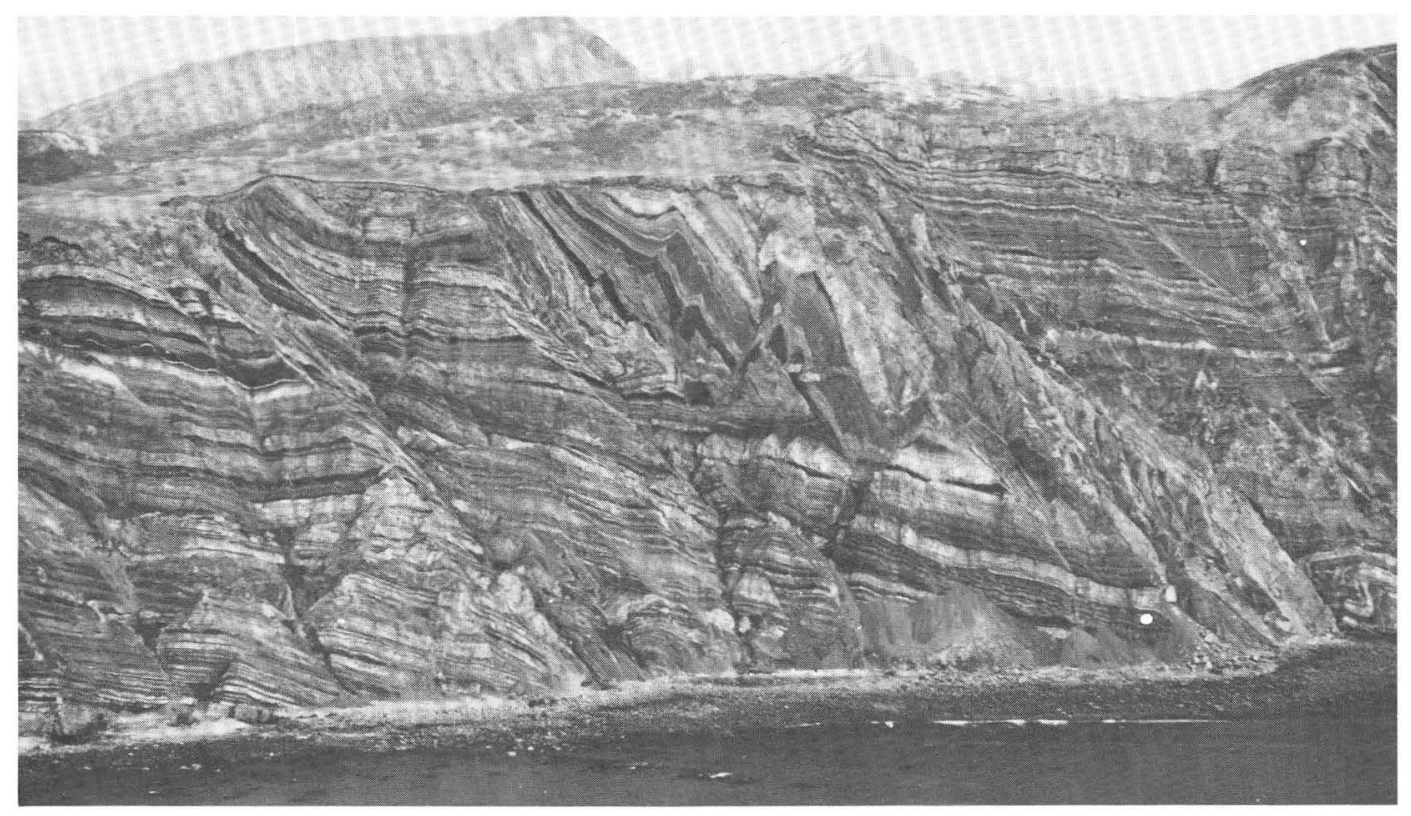

Figure 43.--Structurally disrupted zone in an area to the north of that shown in figure 42; view to the west. Beds are typically $2-4 \mathrm{~m}(6-13 \mathrm{ft})$ in thickness.

ing during deposition and subsidence and partly to einplacement of the early Tertiary Shumagin batholith (Burk, 1965), and it is spatially unrelated to the Miocene deformation discussed in this article.

Inboard or northwest of the zone, Mesozoic and Tertiary rocks are deformed into broad northeast-trending folds cut by high-angle normal and reverse faults that also trend northeast (Burk, 1965; Detterman and others, 1981). Few bedding dips exceed 45 degrees; typically they are much less.

The proximity of the Miocene complex zone to the projected trace of the boundary between the Chugach terrane and the Alaska Peninsula suggests a relation between the two. Moore and others (1983) discuss constraints that require amalgamation of the Chugach terrane and the Alaska Peninsula by Eocene time. Given these constraints, the Oligocene Stepovak Formation and younger rocks may overlie the contact between the two areas, and the zone may represent late structural or isostatic readjustments over the buried boundary. This interpretation would place the terrane boundary somewhat northwest, or inboard, of where it is projected by Moore and others (1983).

\section{REFERENCES CITED}

Burk, C. A., 1965, Geology of the Alaska PeninsulaIsland arc and continental margin: Geological Society of America Memoir 99, 250 p., 2 maps, scales $1: 250,000$ and $1: 500,000$.

Detterman, R. L., Miller, T. P., Yount, M. E., and Wilson, F. H., 1981, Geologic map of the Chignik and Sutwik Island Quadrangles,
Alaska: U.S. Geological Survey Miscellaneous Investigations Map I-1229, 1 sheet, scale $1: 250,000$.

Moore, J. C., 1974, Geologic and structural map of part of the Outer Shumagin Islands, southwestern Alaska: U.S. Geological Survey Miscellaneous Investigations Map I-815, 1 sheet, scale $1: 63,360$.

Moore, J. C., Byrne, Tim, Plumley, P. W., Reid, Mary, Gibbons, Helen, and Coe, R. S., 1983, Paleogene evolution of the Kodiak Islands, Alaska-Consequences of ridge-trench interaction in a more southerly latitude: Tectonics, v. 2, no. 3, p. 265-293.

Wilson, F. H., Gaum, W. C., and Herzon, P. L., 1982, Map and tables showing geochronology and whole-rock geochemistry, Chignik and Sutwik Island Quadrangles, Alaska: U.S. Geological Survey Miscellaneous Field Studies Map MF$1053 \mathrm{M}, 3$ sheets, scale 1:250,000.

Reviewers: J. A. Dumoulin and S. M. Karl

\section{DIGTTAL IMAGE PROCESSING TECHNIQUES FOR DETECTING SURFACE ALTERATION- AN APPLICATION ON THE ALASKA PENINSULA}

\section{by James E. York ${ }^{1}$, Frederic H. Wilson, and Bruce M. Gamble}

${ }^{1}$ Work by York was performed under U. S. Geological Survey contract number 14-08-000120129, Technicolor Government Services, Ine., Anchorage, Alaska. 
The tectonic evolution of the Alaska Peninsula makes it a likely area for the discovery of significant mineral deposits. However, because of problems associated with remoteness and poor weather, little detailed mineral exploration work has been carried on there. This study focuses on using Landsat multispectral scanner data for the Port Moller, Stepovak Bay, and Simeonof Island Quadrangles to detect surface alteration, probably limonitic (iron oxide staining) and(or) argillic (secondary clay minerals) in character, that could be indicative of mineral deposits. The techniques used here are useful for mapping deposits that have exposed surface alteration of at least an hectare, the approximate spatial resolution of the Landsat data. Virtually cloud-free Landsat coverage was used, but to be detected, the alteration area must also be unobscured by vegetation. Not all mineral deposits will be associated with surface alteration, and not all areas of surface alteration will have valuable mineral deposits.

Using known areas of alteration as guides, the Landsat data were digitally processed with contrast stretching, ratio calculations, classification techniques, principal component transformations, and color transformations. The best delineation of known altered areas was obtained with a red-greenblue color combination (assigning red, green, and blue filters to three grey level images) of the first three principal component (eigenvector) images, and with a color transformation image generated using the ratio of band 6 to band 5 , band 6 , and the ratio of band 5 to band 4 as hue, intensity, and saturation, respectively.

Differences in exposed rock and soil types are often subtle in the wavelength regions of the Landsat multispectral scanner. Therefore, contrast stretches of each Landsat band, ratio, and principal component image were developed to enhance those differences. The choice of a contrast stretch will depend on the statistics of the data, which are heavily influenced by the presence of vegetation and water bodies on all Alaska Peninsula Landsat scenes. Before statistics were calculated, an existing digital classification of Landsat land cover types was used to mask out vegetation and water. The statistics on the exposed rocks and soils were then used in an interactive mode with a display screen to select a contrast stretch that best defined the areas of known surface alteration. To maximize the contrast within the exposed rocks and soil, a different non-linear contrast stretch was applied to each grey level image. The technique of masking out vegetation and water was again applied before generating the statistics used to create the principal component images.

The use of ratio images (brightness values of one band divided by those of another) is another method of enhancing differences in exposed rock and soil types. On a spectral reflectance graph (for this discussion, a plot of the logarithm of the re- flectance versus wavelength), various materials may be distinguished at a given wavelength by differing values of the reflectance and slope of the curve. The data from each Landsat band represent the different reflectance values in particular wavelength regions, complicated by variations in illumination caused by topographic relief. Given two wavelengths (for example, two Landsat bands), the average slope of the spectral reflectance curve between these wavelengths is proportional to the logarithm of the ratio of the two corresponding reflectance values. Thus, the ratio images represent the differing values for the slopes of the curves. The ratio calculations also tend to reduce the effect of variations in illumination. Consequently, the ratio images were important in separating rock and soil types that are characterized by similar reflectance values but whose spectral reflectance curves have different slopes.

The principal components of the Landsat data are calculated from a coordinate system defined by the four Landsat bands. The first principal component contains the largest possible variance of the data. Each succeeding principal component has the largest possible variance while remaining orthogonal to the previously determined principal components. The third and fourth principal components, while containing little of the variance of the Landsat data, still provide information useful for detecting surface alteration. Including a contrast stretch of the third or fourth principal component image in a color composite image helped to distinguish altered areas from surrounding areas.

The color transformation image, using hue, intensity, and saturation, gives a better rendition of topographic relief than a red-green-blue color combination of the same three grey level images. Hence, this technique may be preferable to an interpreter. Each of the three grey level images provides some definition of the known altered areas. The ratio of band 6 to band 5 , used as hue, readily separates exposed rock and soil from vegetated terrain. Landsat band 6 , used as intensity, shows the topographic relief as shading. The ratio of band 5 to band 4, used as saturation, gives the known altered areas purer colors than those of surrounding areas.

Both the color transformation image and the color combination of the first three principal components provide fair definition of the known altered areas. These two images give similar results when the characteristics of known altered areas are used as a basis for mapping alteration in unknown areas. The accuracy of the interpretations from the two images will be investigated in the field during 1984 .

The techniques and principles discussed here have potential application to other areas and to other multispectral sensing systems, such as the Landsat thematic mapper. Different grey level images and color combinations from those used here may be preferable in other areas, depending on the 
type of alteration being mapped and the spectral bands available. The choice of images will also depend to some extent on the amount of relief, the distribution and type of vegetative cover, and the sun angle (average amount of illumination).

Reviewers: David Carneggie and K. M. Walker

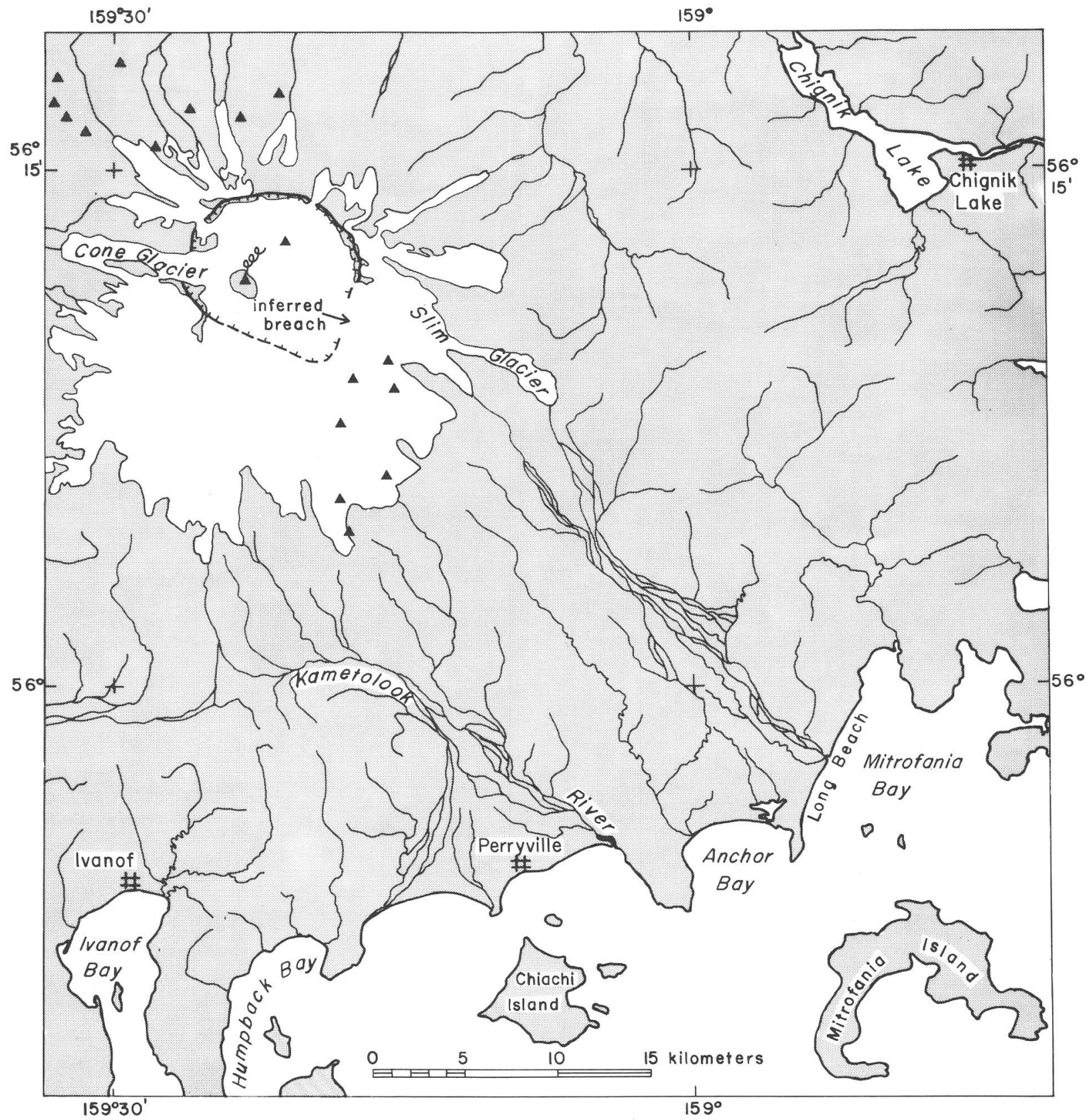

Figure 44.--Mount Veniaminof and surrounding area, including nearby villages. In clear weather, residents of Perryville can see the erupting cone. 


\section{ERUPTION IN AN ICE-FILLED CALDERA, MOUNT VENIAMINOF, ALASKA PENINSULA}

\section{by M. Elizabeth Yount, Thomas P. Miller, Richard P. Emanuel, and Frederic H. Wilson}

The more prominent of the two visible intracaldera cones of Mount Veniaminof went into eruption in early June 1983 and continued until early April 1984. Veniaminof is a 2,507-m-high composite cone having an $8 \times 11-\mathrm{km}$ summit caldera which formed 3,300-3,700 yr B.P. (Miller and Smith, 1977). The active $1.6 \times 1.2-\mathrm{km}$ cone protrudes $200 \mathrm{~m}$ through the glacial ice filling the caldera; it lies in a $60-\mathrm{m}$-long belt of cinder cones that is transverse to the trend of the Aleutian arc (fig. 44).

Reports of eruptions in 1838, 1852, 1874, 1892 and 1930 are limited to brief statements that the volcano was "smoking" (Coats, 1950). Details on more recent eruptions are also vague. An eruption from May 23 to late June, 1939 produced ash plumes about $6,100 \mathrm{~m}$ high and "fire" $450 \mathrm{~m}$ above the crater (Coats, unpub. data). Volcanic activity of unspecified nature occurred in 1944 (Coats, 1950). In May 1956, a pilot reported an ash plume to an elevation of about $6,100 \mathrm{~m}$; the report implied continuous eruption activity during the preceeding two months (Anchorage Times, May 19, 1956).

In this recent eruption, Perryville residents first saw puffs of ash on June 2, 1983. Early manifestations of the Strombolian eruption included a $90-\mathrm{m}$-wide sector graben and a circular depression (400 $\mathrm{m}$ in diameter and approximately $30 \mathrm{~m}$ deep) in the glacial-ice surface directly south of the active cone. By June 9, the 300-m-deep crater of the cone had filled to overflowing with juvenile bombs, blocks, and rising magma, resulting in a lava flow from a low point on the southwest side. The lava flow and subglacial heating caused rapid melting of the glacial ice on the south side of the active cone. By July 13, a vertical-walled, bilobate pit measuring approximately $1,300 \mathrm{~m}$ in the east-west direction, $400-800 \mathrm{~m}$ in the north-south direction, and $60-100 \mathrm{~m}$ deep had formed in the ice. The pit contained a lake of unknown depth and a southwardbuilding lava delta. A subglacial tunnel in the icewall at the east end of the lake indicated drainage eastward along the caldera floor. Another tunnel, less clearly observed, may have drained from the northwest end of the lake toward a breach of the caldera wall at Cone Glacier.

Ash emission was almost continuous during June and July 1983; occasional plumes were estimated to have been as high as $7,800 \mathrm{~m}$. During this time, ash blanketed the intracaldera glacier and steam plumes occurred nearly continuously. The eruption appeared to wane from mid-August to early October, though this may be partly a function of paucity of reports and observations.

Renewed activity was reported in early October. By this time the ice-pit lake had diminish- ed to a small pond located between the wall of the ice pit and a new lava flow lobe. The October 1983March 1984 eruptive phase was characterized by less ash emission and more lava flow activity than the June-August 1983 phase. A succession of flows from the southwest side of the cone resulted in a continual increase in volume and height of new lava in the ice pit, and the pit enlarged slightly in plan, losing its bilobate shape. Each flow lobe cooled rapidly due to the $1,800-\mathrm{m}$ elevation and winter winds; snow was observed on lobes approximately a month old. Perryville residents observed incandescent lava fountaining up to an estimated $100 \mathrm{~m}$ above the cone on January 23, February 6 and 13, and March 2 and 3, 1984. Fountaining was intermittent, lasting one-half to one hour and was followed by quiescent periods of at least 45 minutes. Incandescent glow was last observed March 16, 1984. From mid-March to late April, activity was limited to continual emission of small steam plumes and

Table 10.--Analytical results of samples from Mount Veniaminof volcano

Chemical analyses (original)

\begin{tabular}{|c|c|c|c|}
\hline & $3 \mathrm{AYb} 520^{1}$ & $74 \mathrm{AMm} 42^{2}$ & $73 \mathrm{AMm} 75^{2}$ \\
\hline & $\begin{array}{c}\text { Tephra from } \\
1983 \\
\text { eruption }\end{array}$ & $\begin{array}{c}\text { Active } \\
\text { intracaldera } \\
\text { cone }\end{array}$ & $\begin{array}{c}\text { Inactive } \\
\text { intracaldera } \\
\text { cone }\end{array}$ \\
\hline $\mathrm{SiO}_{2}$ & 54.3 & 54.4 & 53.1 \\
\hline $\mathrm{A}_{2} \mathrm{O}_{3}$ & 17.5 & 17.7 & 19.4 \\
\hline $\mathrm{Fe}_{2}^{2} \mathrm{O}_{3}$ & $9.23^{3}$ & 1.7 & 3.1 \\
\hline $\mathrm{FeO}$ & --- & 6.3 & 5.0 \\
\hline $\mathrm{MgO}$ & 3.37 & 4.0 & 4.3 \\
\hline $\mathrm{CaO}$ & 8.09 & 8.6 & 9.6 \\
\hline $\mathrm{Na}_{2} \mathrm{O}$ & 3.72 & 3.6 & 2.7 \\
\hline $\mathrm{K}_{2} \mathrm{O}$ & 1.13 & 0.90 & 0.85 \\
\hline $\mathrm{H}_{2}^{2} \mathrm{O}^{+}$ & -- & 0.22 & 0.38 \\
\hline $\mathrm{H}_{2}^{2} \mathrm{O}-$ & --- & 0.21 & 0.06 \\
\hline $\mathrm{TiO}_{2}$ & 1.32 & 1.1 & 1.1 \\
\hline $\mathrm{P}_{2} \mathrm{O}_{5}^{-}$ & 0.34 & 0.30 & 0.26 \\
\hline $\mathrm{MnO}^{\circ}$ & 0.16 & 0.15 & 0.16 \\
\hline $\mathrm{CO}_{2}$ & --- & 0.01 & 0.05 \\
\hline Sum & 99.16 & 99.2 & 100 \\
\hline $\mathrm{Fe} 0 * / \mathrm{MgO}$ & 2.44 & 1.93 & 1.81 \\
\hline
\end{tabular}

1 X-ray fluorescence; $83 \mathrm{AYb} 520$ contains microphenocrysts of plagioclase, olivine, and clinopyroxene in microlite-laden glass; refractive index of glass $=1.565 ; \delta^{18} 0=6.2 \%$; ${ }^{78} \mathrm{Sr}{ }^{86} \mathrm{Sr}=.7034$

2 Rapid rock

$\begin{array}{lll}3 & \mathrm{Fe}_{\mathrm{T}} \mathrm{O}_{3}\end{array}$ 
rare ash bursts lasting up to two hours. An observation flight on April 11 revealed that all lavaflow lobes in the pit were dusted with snow.

An ash sample was collected July 25, 1984, from vegetation $18 \mathrm{~km}$ southeast of the erupting cone. Table 10 compares the whole-rock major-element composition of this tephra sample with analyses of intracaldera cone samples collected in 19731974. All samples are basaltic andesite; all are classified as tholeiitic based on the criteria of Miyashiro (1974), as are four Veniaminof samples described in Kay and others (1982). The eruption of basaltic andesite within the caldera implies that a large, high-level chamber containing silicic magma is not present beneath Veniaminof.

Villages subject to potential hazards from the eruption are Ivanof, Perryville, and Chignik Lake, $33 \mathrm{~km}, 35 \mathrm{~km}$, and $40 \mathrm{~km}$, respectively, from the volcanic vent. Ivanof and Chignik Lake are separated from the Veniaminof caldera by mountains; therefore, barring an extremely violent eruption, the main hazard to them is from disruptive, but not life-threatening, ash fall. However, a slightly higher hazard potential exists for Perryville. The north wall of Veniaminof's caldera is $300 \mathrm{~m}$ high above the icefield, whereas to the south intracaldera ice drapes over the wall, merging with the icefield which covers most of the south flank (fig. 44). The position of the south rim is inferred from the ice-surface gradient and ice fracture pattern. Branches of the Kametolook River east and west of Perryville originate on Veniaminof's glacial-covered south flank. Sudden, southward-directed mass movements, such as lahars or jökulhlaup floods of sufficiently large volume, could overtop or surround the crescent of low hills north of Perryville. Both the relatively quiet effusive nature of this eruption and the lack of evidence for a high-level silicic magma chamber diminish the likelihood of catastrophic pyroclastic flows and lahars, but accumulation of the glacial meltwater lake and its subsequent subglacial drainage present the threat of a jökulhlaup that could flow toward Perryville.

An estimated $0.07 \mathrm{~km}^{3}$ of ice was melted from early June to mid-August 1983. Water escaped into the atmosphere mainly by evaporation from the lava-warmed lake and steam emission from the cone. Water also drained along the caldera floor through subglacial tunnels, some percolating into porous volcanic strata. Whether sudden or not, egress of ponded subglacial water from the caldera is controlled by breaches in the rim. The rim is breached on the west where Cone Glacier has cut a notch about $400 \mathrm{~m}$ in width. An eastward-facing glacial breach south of Slim Glacier is inferred from ice fracture patterns. Thus the two most likely channels for drainage from the caldera appear to be westward into the Cone Glacier drainage and southeastward into an unnamed river which empties into Mitrofania Bay at Long Beach, well east of
Perryville. Further study of the intracaldera glacier will test the inference of an eastward breach.

\section{REFERENCES CITED}

Anchorage Times, 540 W. 4th Ave., Anchorage, AK 99501

Coats, R. R., 1950, Volcanic activity in the Aleutian arc: U.S. Geological Survey Bulletin 974-B, $49 \mathrm{P}$.

Kay, S. M., Kay, R. W., and Citron, G. P., 1982 , Tectonic controls on tholeiitic and calcalkaline magmatism in the Aleutian arc: Journal of Geophysical Research, v. 87, p. 4051-4072.

Miller, T. P., and Smith, R. L., 1977, Spectacular mobility of ash flows around Aniakchak and Fisher calderas, Alaska: Geology, v. 5, p. 173-176.

Miyashiro, Akiho, 1974, Voleanic rock series in island arcs and active continental margins: American Journal of Science, v. 274, p. 321355 .

Reviewers: J. R. Riehle and A. B. Till

(Photographs of the eruption are on the front and back covers of this circular.)

\section{NEWLY DISCOVERED HOLOCENE VOLCANIC VENTS, PORT MOLLER AND STEPOVAK BAY QUADRANGLES}

\section{by M. Elizabeth Yount, Frederic H. Wilson, and John W. Miller}

Reconnaissance mapping in 1982-83 suggests previously unreported Holocene volcanic activity in the area 14-24 km southwest of Kupreanof Volcano (fig. 45). One young volcanic vent has been observed along the divide between Stepovak Bay and Bear Lake, and the locations of two others are inferred from the position of morphologically young lava flows mapped in valleys draining into Clark Bay, Grub Gulch, and Ramsey Bay. Other morphologically young flows extending northwest from the divide are evident on aerial photographs.

A discrete volcanic cone $180 \mathrm{~m}$ high with a small summit crater is located at lat $55^{\circ} 54^{\prime} 47^{\prime \prime} \mathrm{N}$., long $160^{\circ} 02^{\prime} 09^{\prime \prime} \mathrm{W}$. on the divide between Grub Gulch and Bear Lake (1, fig. 45). A flow with wellpreserved lava levees and flow ridges extends from the cone northwest toward Bear Lake. Two other small lava flows, with well-preserved ropy flow ridges suggesting a late Holocene age, extend eastnortheast of the cone (fig. 46). Both the westernmost stream valley draining into Ramsey Bay and the eastern stream valley draining into Grub Gulch contain more voluminous, but less well preserved, slightly older flows that originate from near this cone. 


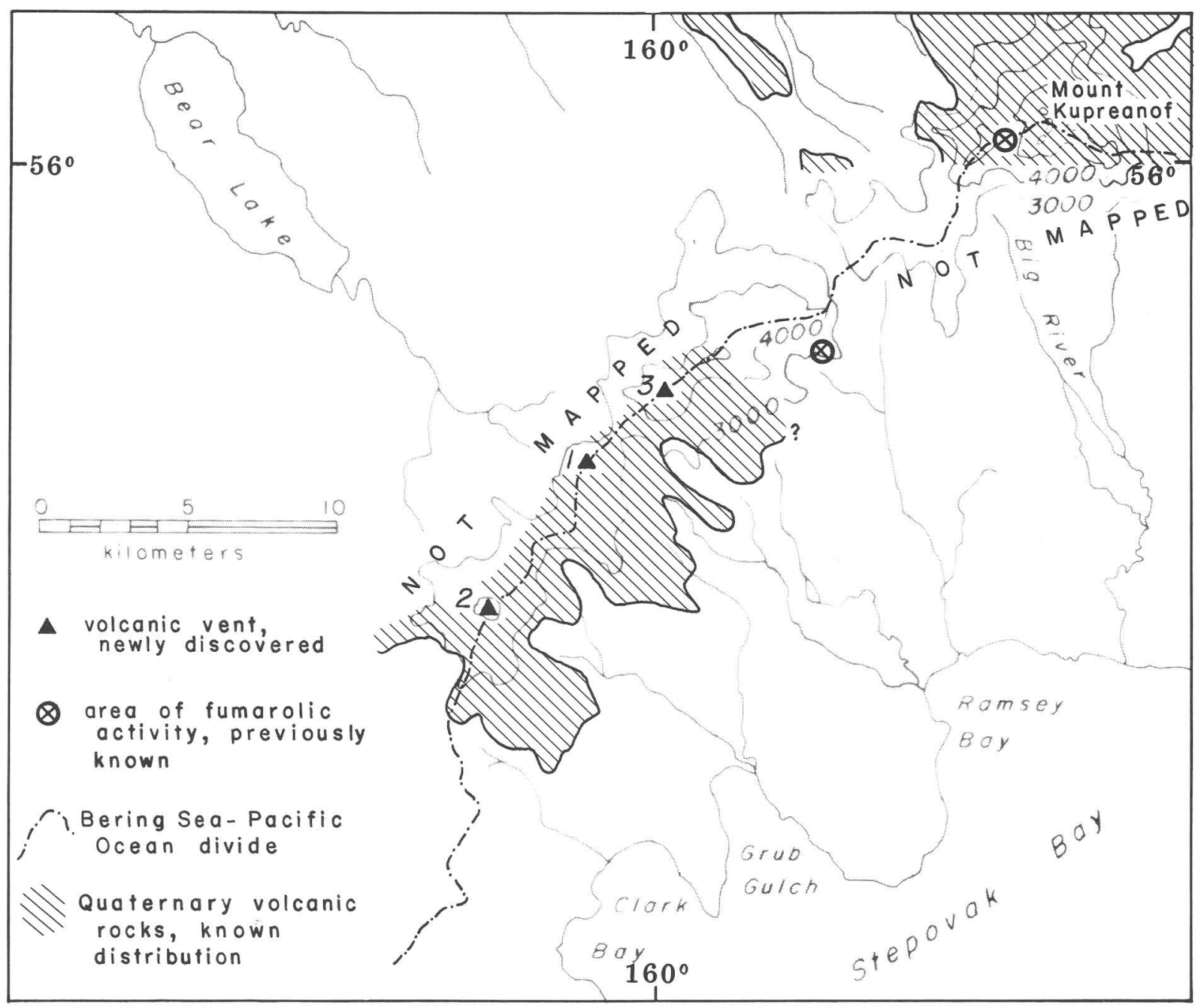

Figure 45.--Location of newly discovered volcanic vents relative to Mount Kupreanof. Mapped distribution of Quaternary volcanic rocks is shown in stippled pattern (north of lat $56^{\circ} \mathrm{N}$. from Detterman and others, 1981). Dot-dash line is Bering Sea-Pacific Ocean divide.

A conical ice cap located at the center of a group of Quaternary flows and volcaniclastic material probably covers a volcanic vent (2, fig. 45 ; lat $55^{\circ} 52^{\prime} 10^{\prime \prime} \mathrm{N}$., long $160^{\circ} 05^{\prime} 30^{\prime \prime} \mathrm{W}$.). Relatively uneroded andesite(?) flows greater than $150 \mathrm{~m}$ thick, which drape into the present valley east and south of the cone, are the youngest flows from this vent area. Slightly older andesite flows and interbedded rubble, probably from the same vent area, crop out as isolated caps on ridges south and west of vent 2 . At lower elevations, heavily vegetated flows, seeming to originate from the same area, almost reach tidewater at Clark Bay.

Other young flows in the headwaters of valleys draining into Ramsey Bay originate near the ridge crest between vent 1 and Mount Kupreanof, suggesting the presence of a third Holocene vent ( 3 , fig. 45) at approximately lat $55^{\circ} 56^{\prime} \mathrm{N}$. , long $160^{\circ}$ $00^{\circ} \mathrm{W}$.

All six samples of fresh volcanic rock from the vicinity of these vents that were examined petrographically are considered to be andesite, based on their phenocryst mineralogy. All samples are porphyritic, containing phenocrysts of plagioclase, clinopyroxene, and magnetite. Plagioclase is the most abundant phenocryst phase in five of the six samples, with plagioclase phenocrysts ranging from 5 to 25 percent by volume. In the sixth sample, clinopyroxene grains up to $5 \mathrm{~mm}$ in length total 7-10 percent. Three samples contain orthopyroxene-one in minor amounts, one mostly in glomerophyric clots with plagioclase, and one as a 


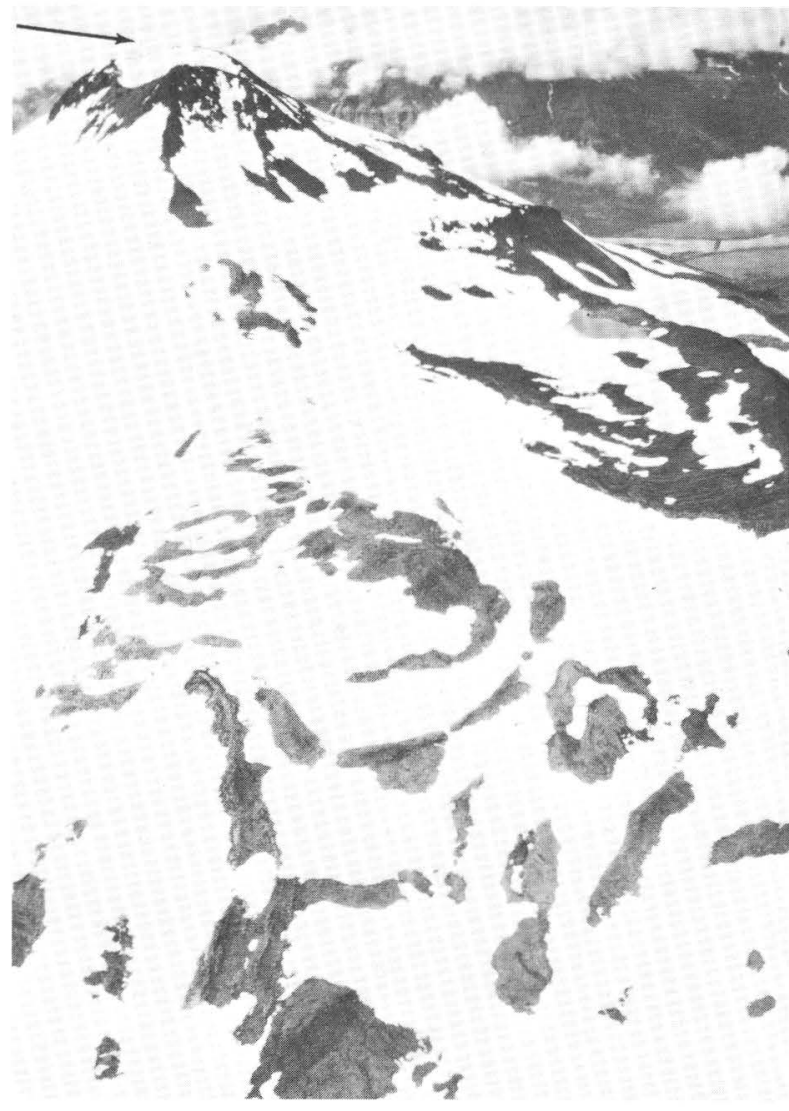

Figure 46.--Flow ridges on lava flows (foreground) from vent 1 (arrow), on the divide between Grub Gulch and Bear Lake.

varietal phenocryst phase. None of the samples examined contains either olivine or hornblende phenocrysts.

The active fumaroles at the head of Big River (fig. 45) are nearly at the center of the Kupreanof volcanic edifice. Coats (1950) classified Mount Kupreanof as extinct; however, recent mapping indicates it has had Holocene activity (T. P. Miller, U.S. Geological Survey, oral commun., April $16,1984)$. The vents discussed here, southwest of Mount Kupreanof, have been the loci of Pleistocene and Holocene volcanic eruptions, as has Kupreanof. Flows from these vents probably interfinger with Kupreanof flows in the northwest corner of the Stepovak D-6 Quadrangle. Eakins (1970) reported fumarolic activity at the head of a drainage into Ramsey Bay (fig. 45). Further mapping may locate other volcanic vents between Mount Kupreanof and those discussed here.

\section{REFERENCES CITED}

Coats, R. R., 1950, Volcanic activity in the Aleutian arc: U.S. Geological Survey Bulletin 974-B, 49 p.
Detterman, R. L., Miller, T. P., Yount, M. E., and Wilson, F. H., 1981, Quaternary geologic map of the Chignik and Sutwik Island Quadrangles, Alaska: U.S. Geological Survey Miscellaneous Investigations Series Map I1292,1 sheet, scale $1: 250,000$.

Eakins, G. R., 1970, Mineralization near Stepovak Bay, Alaska Peninsula, Alaska: Alaska Division of Mines and Geology Special Report No. 4, 12 p.

Reviewers: J. R. Riehle and D. L. Carter

\section{SOUTHERN ALASKA}

(Figure 47 shows study areas described.)

\section{AGE OF INTRUSION AND METAMORPHISM OF A GRANODIORITE \\ IN THE LAKE GEORGE TERRANE, NORTHEASTERN MOUNT HAYES QUADRANGLE}

\section{by John N. Aleinikoff and Warren J. Nokleberg}

The Lake George terrane (Nokleberg and others, 1983), in the northeastern part of the Mount Hayes Quadrangle, consists predominantly of poly-

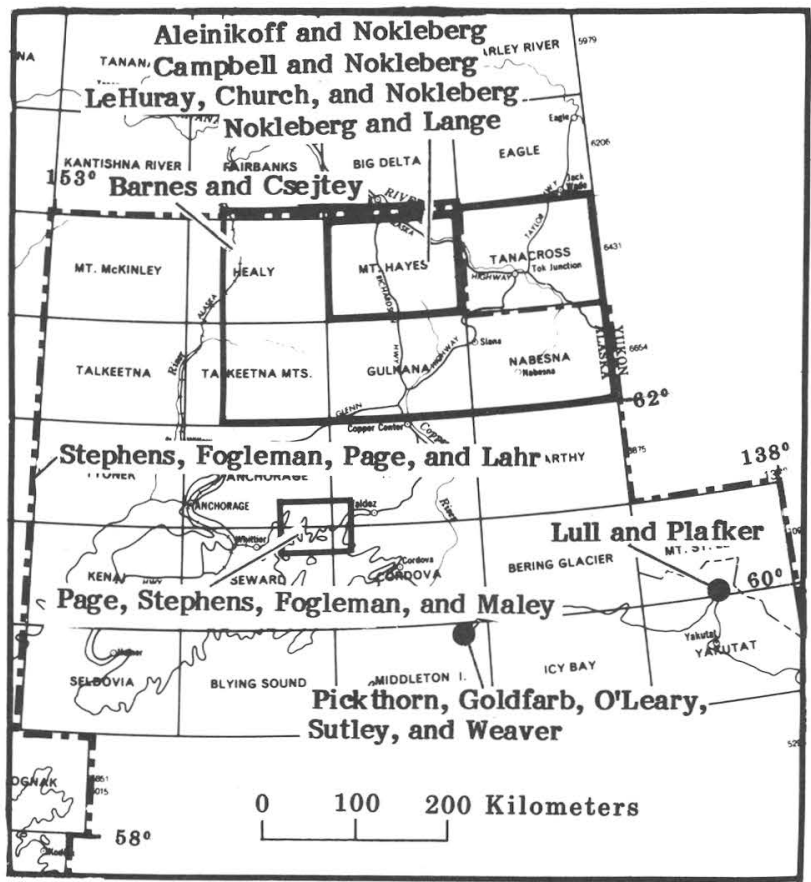

Figure 47.--Areas in southern Alaska discussed in this circular. Outlines define the areas described by the indicated authors. 
Table 11.--Uranium-lead isotopic data for zircon from meta-granodiorite in the Lake George terrane, Mount Hayes Quadrangle

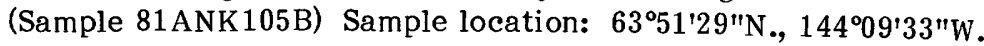

Age constants: $\lambda^{235} \mathrm{U}=0.98485 \times 10^{-9} / \mathrm{y}, \lambda^{238} \mathrm{U}=0.155125 \times 10^{-9} / \mathrm{y}$, and ${ }^{238} \mathrm{U} /{ }^{235} \mathrm{U}=137.88$

Analysts: Lynn B. Fisher (chemistry) and John N. Aleinikoff (mass spectrometry)

\begin{tabular}{|c|c|c|c|c|c|c|c|c|c|}
\hline \multirow{3}{*}{$\begin{array}{c}\text { Size } \\
\text { fraction }\end{array}$} & \multicolumn{6}{|c|}{ Concentration } & \multirow{3}{*}{$\frac{206 \mathrm{~Pb}}{238 \mathrm{U}}$} & \multicolumn{2}{|c|}{ Age (m.y.) } \\
\hline & \multirow[b]{2}{*}{$\mathrm{U}$} & \multirow[b]{2}{*}{$\mathrm{Pb}$} & \multirow[b]{2}{*}{${ }^{204} \mathrm{~Pb}$} & \multicolumn{2}{|c|}{ Atomic percent* } & \multirow[b]{2}{*}{${ }^{208} \mathrm{~Pb}$} & & \multirow{2}{*}{$\frac{207 \mathrm{~Pb}}{235_{\mathrm{U}}}$} & \multirow{2}{*}{$\frac{{ }^{207} \mathrm{~Pb}}{206 \mathrm{~Pb}}$} \\
\hline & & & & ${ }^{206} \mathrm{~Pb}$ & ${ }^{207} \mathrm{~Pb}$ & & & & \\
\hline$(+150)$ NMD & 649 & 35 & 0.009 & 86.81 & 4.963 & 8.216 & 341 & 354 & 437 \\
\hline$(+150) \mathrm{Abr}$ & 548 & 33 & 0.084 & 82.62 & 5.887 & 11.411 & 355 & 370 & 467 \\
\hline$(+150)$ & 659 & 36 & 0.007 & 87.04 & 4.983 & 7.968 & 346 & 360 & 453 \\
\hline$(-150+200)$ & 700 & 36 & 0.004 & 87.33 & 4.802 & 7.868 & 329 & 336 & 384 \\
\hline$(-325)$ & 740 & 35 & 0.004 & 86.44 & 4.715 & 8.838 & 301 & 309 & 362 \\
\hline$(-325+400)$ & 704 & 35 & 0.017 & 86.01 & 4.867 & 9.105 & 308 & 314 & 361 \\
\hline$(-400)$ & 676 & 32 & 0.006 & 86.42 & 4.724 & 8.849 & 298 & 305 & 359 \\
\hline
\end{tabular}

*Blank corrected

deformed, coarse-grained, pelitic, muscovitequartz-biotite-garnet schist, relatively younger medium- to coarse-grained schistose granodiorite and diorite, and coarse-grained augen schist and gneiss derived from quartz monzonite. Protoliths for the pelitic schist range from siltstone to shale. Abundant relict igneous textures and structures occur in the metamorphosed plutonic rocks. Field and petrologic relations indicate that the metamorphosed plutonic rocks probably intruded at moderate to deep levels. The pelitic schist and metamorphosed plutonic rocks are cataclastically deformed and regionally metamorphosed under middle or upper amphibolite-facies conditions into mylonitic schist and gneiss. Schistosity and parallel foliation dip gently north and south in the pelitic schist and metamorphosed plutonic rocks. Small-scale isoclinal fold axes parallel the schistosity and foliation or the compositional layering in the pelitic schist and disrupt an earlier schistosity and foliation, which apparently occurred prior to the isoclinal folding; these structural relations indicate that two major structural and possibly regional-grade metamorphic events have affected the pelitic schist. Replacement and retrogression of the upper amphibolite-facies assemblage to lower greenschist facies also occurs locally.

Sample 81 ANK105B is a coarse-grained, schistose granodiorite, composed of poikiloblastic hornblende, plagioclase, quartz, $\mathrm{K}$-feldspar and minor biotite, with accessory zircon, apatite, sphene, and opaque minerals. The sample is relatively unaltered, with only minor sericitization of the plagioclase, so that an $\mathrm{Rb}-\mathrm{Sr}$ internal isochron could be determined. Zircons from this sample are euhedral, contain a few clear and opaque inclusions, and have length-to-width ratios ranging from $2: 1$ to $3: 1$. The zircons are undoubtedly igneous in origin and, as such, should provide evidence for the age of intrusion of the granodiorite.

Seven size fractions of zircon were analyzed for $\mathrm{U}$ and $\mathrm{Pb}$ isotopes (table 11). Uranium concentrations in these zircons are typical of zircons from granitic rocks, ranging from 548 to $740 \mathrm{ppm}$. ${ }^{207} \mathrm{~Pb} /{ }^{206} \mathrm{~Pb}$ ages increase with increasing grain size, ranging from 359 to $467 \mathrm{~m} . \mathrm{y}$. On a concordia diagram (fig. 48), the four coarse fractions form a trend with an apparent lower intercept age of about $310 \mathrm{~m} . \mathrm{y}$. Of these four points, the oldest ${ }^{207} \mathrm{~Pb} /{ }^{206} \mathrm{~Pb}$ age $(467$ m.y. $)$ is in the $(+150) \mathrm{Abr}$ fraction; these zircons were abraded, so that only rounded cores were analyzed. These zircons were separated from the population labeled $(+150)$ NMD, which was analyzed separately and has a ${ }^{207} \mathrm{~Pb} /{ }^{206} \mathrm{~Pb}$ age of 437 m.y. Thus, the cores of the coarse zircons contain inherited radiogenic lead from an older source, probably derived either during anatexis or assimilation as the granodiorite was intruded. As such, old inherited zircon may have acted as nucleation sites for younger zircon growth in the granodiorite magma. The next finer fraction, $(-150+200)$, with a ${ }^{207} \mathrm{~Pb} /{ }^{206} \mathrm{~Pb}$ age of $384 \mathrm{~m} . \mathrm{y}$., 
contains somewhat less inheritance. The three finest fractions, $(-325),(-325+400)$, and $(-400)$, all have ${ }^{207} \mathrm{~Pb} /{ }^{206} \mathrm{~Pb}$ ages of about $360 \mathrm{~m} . \mathrm{y}$. Based on the trend of decreasing inheritance with decreasing grain size, we suggest that the age of intrusion of the granodiorite is about $360 \mathrm{~m} . \mathrm{y}$. A best-fit line, calculated through the data from the three finegrained fractions, has concordia intercept ages of $367 \pm 35$ and $31 \pm 136 \mathrm{~m} . \mathrm{y}$. The calculated 2 -sigma uncertainties of the intercepts are large due to slight differences (3 m.y.) in the ${ }^{207} \mathrm{~Pb} /{ }^{206} \mathrm{~Pb}$ ages and the small range (298-314 m.y.) in the $\mathrm{Pb} / \mathrm{U}$ ages. We feel confident that the ${ }^{207} \mathrm{~Pb} /{ }^{206} \mathrm{~Pb}$ ages record the age of intrusion at about $360 \mathrm{~m} . \mathrm{y}$. The nearly identical ages of these fractions suggest that discordancy in the $\mathrm{U}-\mathrm{Pb}$ systematics was caused mainly by modern lead loss. However, well-known Cretaceous thermal events, occurring from about $115 \mathrm{~m} . \mathrm{y}$. to at least $65 \mathrm{~m} . \mathrm{y}$. (Dadisman, 1980), may have been responsible for some of the scatter and discordance in the data. Prior to post-Devonian lead loss, the seven data points probably were aligned along an inheritance chord, with the finer fractions (containing no inheritance) being concordant at the lower intercept of about $360 \mathrm{~m} . \mathrm{y}$. and the coarser fractions occurring along the chord leading to the age of inheritance. Subsequent lead loss destroyed this linearity. Based on these data, therefore, no estimate of the age of inheritance can be made, except that it must be Ordovician or older. Analyses of zircons from metaigneous rocks throughout the Yukon-Tanana terrane indicate an Early Proterozoic (2.0-2.3 b.y.) source for most of the inheritance in the region (Aleinikoff, 1984).

Because the zircon $\mathrm{U}-\mathrm{Pb}$ data do not suggest the age of metamorphism of the granodiorite, an internal $\mathrm{Rb}-\mathrm{Sr}$ isochron from the same sample was determined. $\mathrm{Rb}-\mathrm{Sr}$ data for samples of biotite, $\mathrm{K}-$ feldspar, plagioclase and a whole-rock split (table 12) are colinear on an isochron diagram (fig. 49) and have an age of $102 \pm 2 \mathrm{~m} . \mathrm{y}$. Rocks from the Lake George terrane are poly-deformed; they were metamorphosed to middle and upper amphibolite facies

Table 12.--Rubidium and strontium analy tical results Sample no. 81ANK105B, $\lambda^{87} \mathrm{Rb}=1.42 \times 10^{-11} / \mathrm{y}$ Analysts: Kiyoto Futa (chemistry) and Karin Barovich (mass spectrometry)

\begin{tabular}{|c|c|c|c|c|}
\hline Sample & $\begin{array}{c}\mathrm{Rb} \\
(\mathrm{ppm})\end{array}$ & $\begin{array}{c}\mathrm{Sr} \\
(\mathrm{ppm})\end{array}$ & $\frac{{ }^{87} \mathrm{Rb}}{{ }^{86} \mathrm{Sr}}$ & $\frac{{ }^{87} \mathrm{Sr}}{{ }^{86} \mathrm{Sr}}$ \\
\hline Whole-rock & 91.9 & 188.0 & 1.418 & 0.72111 \\
\hline Plagioclase & 13.5 & 230.6 & 0.1696 & .71936 \\
\hline K-feldspar & 267.0 & 341.4 & 2.296 & .72210 \\
\hline Biotite & 544.5 & 19.4 & 82.28 & .83859 \\
\hline
\end{tabular}

and then weakly retrogressed to greenschist facies. Resetting of the $\mathrm{Rb}-\mathrm{Sr}$ mineral ages is accomplished at greenschist facies temperatures (approximately $300-350^{\circ} \mathrm{C}$ ) or higher, suggesting that the internal equilibration at $102 \mathrm{~m} . \mathrm{y}$. may be correlative with retrogressive metamorphism occurring in the Early Cretaceous. According to Aleinikoff and Cynthia Dusel-Bacon (U.S. Geological Survey, written commun., 1984), Rb-Sr mineral ages in augen gneiss about $40 \mathrm{~km}$ to the north were reset at $115 \mathrm{~m} . \mathrm{y}$. , and quartz monzonite from the Macomb terrane immediately to the south of the Lake George terrane has an internal isochron age of $110 \mathrm{~m} . \mathrm{y}$. Based on the $\mathrm{U}-\mathrm{Pb}$ and $\mathrm{Rb}-\mathrm{Sr}$ data in and surrounding the Lake George terrane, our conclusions are: (1) plutonism in the Lake George terrane occurred at about $360 \mathrm{~m} . \mathrm{y}$., about $20 \mathrm{~m} . \mathrm{y}$. earlier than batholitic intrusions of protoliths of augen gneisses to the north and about 0-25 m.y. later than igneous activity in terranes to the south (but north of the Denali fault) in the Mount Hayes Quadrangle (Aleinikoff, 1984); (2) two periods of metamorphism affected rocks in the Lake George terrane-the first (amphibolite facies) event occurred between 360 and about $115 \mathrm{~m} . \mathrm{y}$. and the second, a greenschistfacies retrograde event, occurred at about $102 \pm 2$ m.y.; (3) because several distinct terranes in the Mount Hayes Quadrangle record a thermal resetting of the $\mathrm{Rb}-\mathrm{Sr}$ systematics in the Early Cretaceous, these terranes probably were assembled prior to or during the retrograde metamorphism at 100-115 $\mathrm{m} . \mathrm{y}$. A possible cause for this resetting is the "docking" of Wrangellia [as proposed by Silberman and others (1981) at $112 \pm 11 \mathrm{m.y}$.$] against the ter-$ ranes north of the Denali fault, which caused widespread penetrative deformation linked with northward overthrusting.

\section{REFERENCES CITED}

Aleinikoff, J. N., 1984, Age and origin of metaigneous rocks from terranes north and south of the Denali fault, Mt. Hayes Quadrangle, east-central Alaska: Geological Society of America Abstracts with Programs, v. 16., no. 5, p. 266.

Dadisman, S. V., 1980, Radiometric ages of rocks in south-central Alaska and western Yukon Territory: U. S. Geological Survey Open-File Report 80-183, 82 p., scale 1:1,000,000.

Nokleberg, W. J., Aleinikoff, J. N., and Lange, I. M., 1983, Origin and accretion of Andean-type and island arc terranes of Paleozoic age juxtaposed along the Hines Creek fault, Mt. Hayes Quadrangle, eastern Alaska Range, Alaska: Geological Society of America Abstracts with Programs, v. 15, no. 5, p. 427.

Silberman, M. L., MacKevett, E. H., Jr., Connor, C. L., Klock, P. R., and Kalechitz, G., 1981, KAr ages of the Nikolai Greenstone from the McCarthy Quadrangle, Alaska-the "docking" 


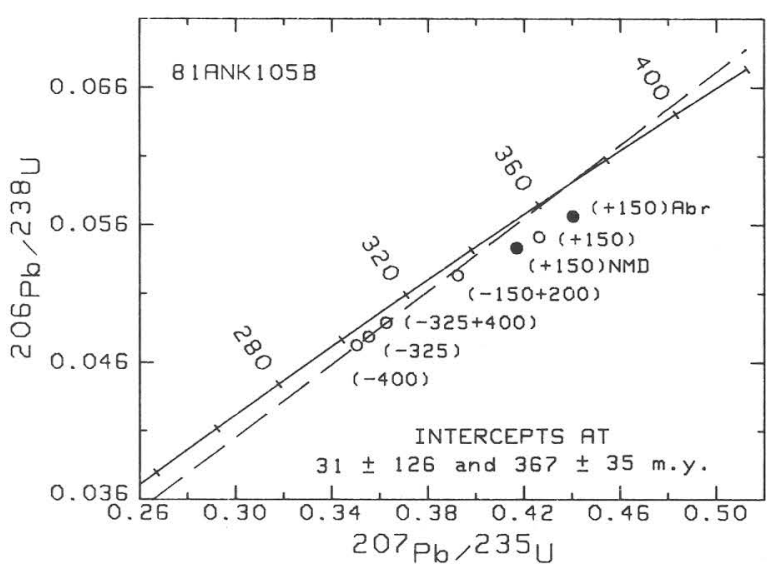

Figure 48.--Concordia plot of $\mathrm{Pb} / \mathrm{U}$ data from seven splits from sample 81ANK105B. Split labelled $(+150)$ Abr subdivided from the $(+150)$ NMD split and abraded. Best-fit line through the three finest fractions has intercept ages of $31 \pm 136$ and $367 \pm 35$ m.y. Uncertainties in $\mathrm{Pb} / \mathrm{U}$ data are 1.2 percent. See text for additional explanation.

of Wrangellia, in Albert, N. R. D., and Hudson, Travis (eds.), The United States Geological Survey in Alaska - Accomplishments during 1979: U.S. Geological Survey Circular 823-B, p. B61-B63.

Reviewers: Z. E. Peterman and N. J. Silberling

\section{STRONG MAGNETIC AND GRAVITY CONTRASTS ACROSS THE TALKEETNA, TOTSCHUNDA, AND EUREKA CREEK FAULTS VERSUS \\ THE LESSER GEOPHYSICAL EXPRESSION OF THE DENALI FAULT AND ITS STRANDS: A GEOLOGICAL PUZZLE FOR TACT PROGRAM}

\section{by David F. Barnes and Béla Csejtey, Jr.}

Published aeromagnetic and gravity maps show strong contrasts across the Talkeetna thrust fault system (Csejtey and others, 1982), which is the northern boundary of the Talkeetna superterrane (combining Wrangellia and Peninsular terranes). These maps fail to show significant aeromagnetic contrasts across parts of the Denali fault system, which has strong topographic expression that has been recognized for almost 80 years (Mendenhall, 1905 ) and is locally an important geologic boundary (St. Amand, 1957). The Denali fault system is considered a major arcuate geologic discontinuity that may extend nearly $2,000 \mathrm{~km}$ from Goodnews on the Bering Sea through the Alaska Range to Chatham

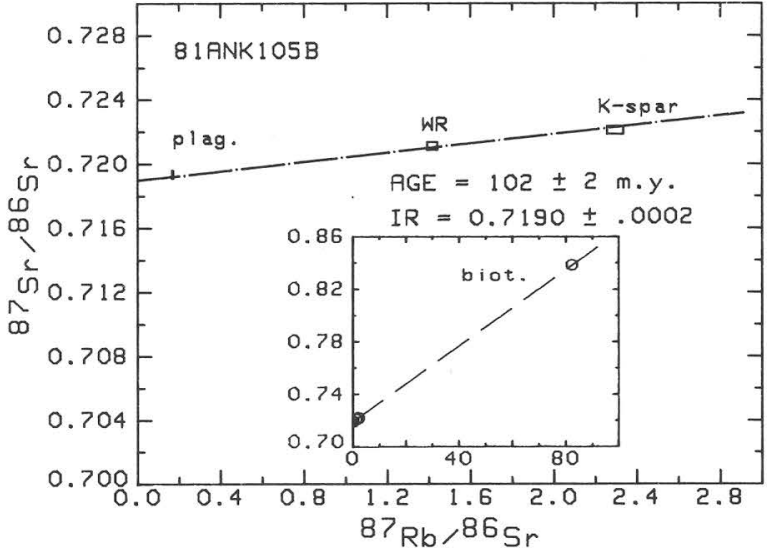

Figure 49.--Internal $\mathrm{Rb}-\mathrm{Sr}$ isochron of $102 \pm 2$ m.y. from sample 81ANK105B. Data from splits of plagioclase, whole-rock, K-feldspar, and biotite. Errors are 0.035 percent $\left({ }^{87} \mathrm{Sr} /{ }^{86} \mathrm{Rb} /{ }^{86} \mathrm{Sr}\right)$. Inset shows location of biotite relative to the other three points.

Strait in southeastern Alaska via the Holitna, Farewell, Hines Creek, McKinley, Shakwak, and Lynn Canal faults. Horizontal displacements as large as $500 \mathrm{~km}$ have been postulated (Forbes and others, 1973; Wahrhaftig and others, 1975). The Talkeetna thrust fault is a recently recognized feature (Csejtey and others, 1978, 1982), which either abuts the Denali fault (Nokleberg and others, 1982) or divides into two splays - the Broxson Gulch and the Eureka Creek thrusts (Nokleberg and others, 1982). An early, unreversed, seismic refraction profile suggested a discontinuity at the Eureka Creek fault. The published geophysical data and their relation to the fault systems will be tested by modern seismic refraction methods in a profile planned as part of the Trans-Alaska Crustal Transect (TACT) project during the summer 1984 .

A recent aeromagnetic map of central Alaska (fig. 50A) (Godson and others, 1982) shows the traces of the Denali, Talkeetna, Broxson Gulch, and Eureka Creek faults, as well as the names of terranes they divide. The contrast in magnetic pattern between the Talkeetna superterrane and the adjacent Yukon-Tanana terrane and Jurassic and Cretaceous flysch is striking. The northern part of the Talkeetna superterrane is characterized by small, irregularly shaped, high-amplitude (1,0005,000 gamma) anomalies, caused mostly by nearsurface bodies of the Triassic Nikolai Greenstone and underlying tabular ultramafic bodies (Campbell, 1984). Flysch and schist units to the north are less 
A.
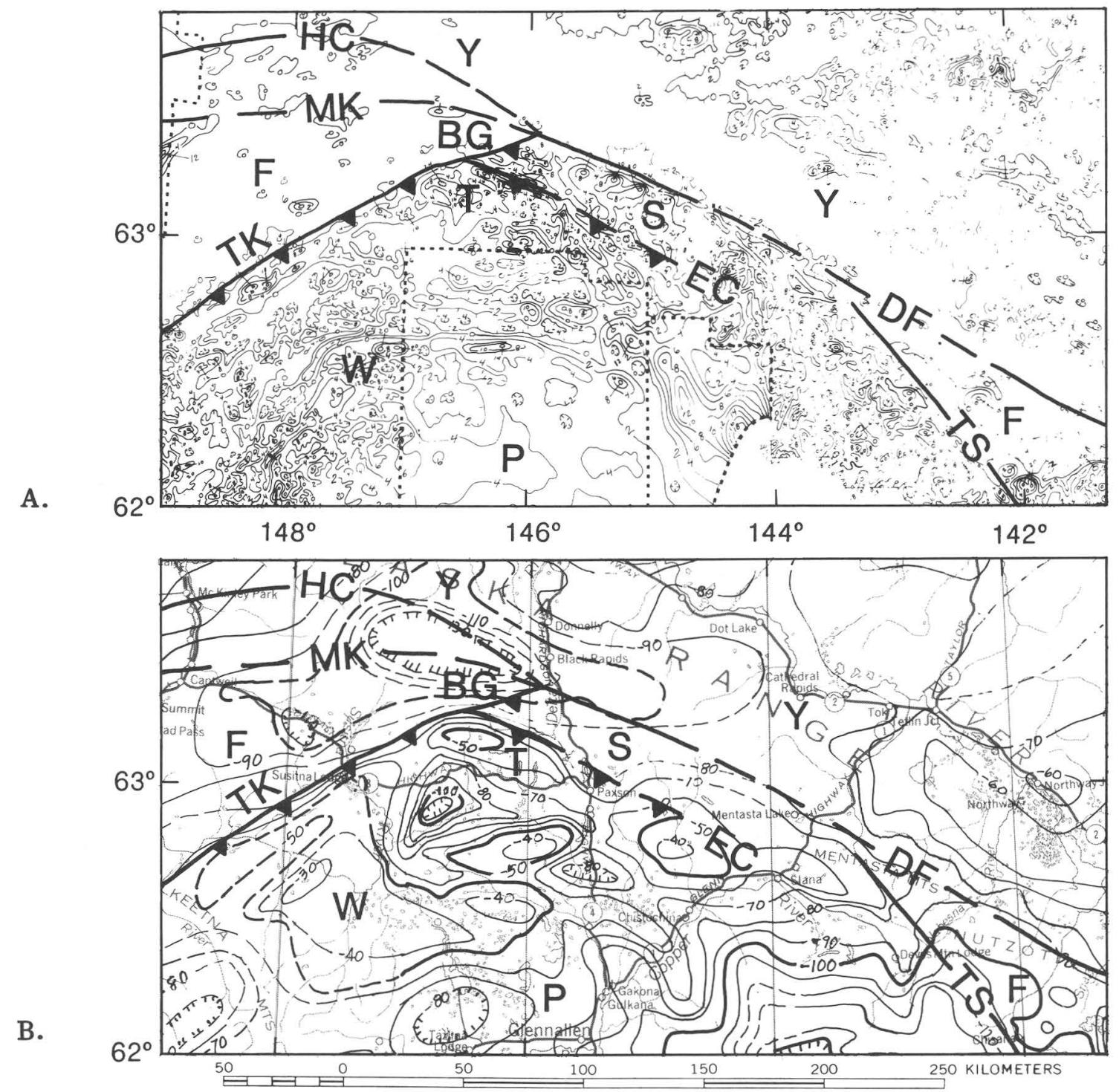

Figure 50.--Maps showing geophysical contours, superimposed faults of the Denali and related systems, and recognized terranes. Except where noted, faults are located on the basis of geologic mapping. DF, Denali fault; HC, Hines Creek strand of Denali fault; MK, McKinley strand of Denali fault; TS, Totschunda fault; TK, Talkeetna thrust; EC, Eureka Creek thrust (with dashed extension based more on gravity than on magnetic and geologic data); BG, Broxson Gulch fault; W, Wrangellia terrane; S, Slana River subterrane; T, Tangle subterrane; $P$, Peninsular terrane; Y, Yukon-Tanana terrane; F, Jurassic and Cretaceous flysch. (A): Part of the aeromagnetic map of Alaska (after Godson, 1982); dotted lines are survey boundaries. (B): Part of the Bouguer gravity map of Alaska (after Barnes, 1977).

magnetic and have relatively flat and expressionless fields. West of the Talkeetna thrust fault, neither the McKinley nor the Hines Creek splay have obvious magnetic expression. According to Csejtey and others (1983), neither of these faults appears to be a terrane-boundary fault, but this interpretation is controversial. The eastern end of the Denali fault also has lesser magnetic expression where a flysch unit crops out on its southern side, and the more obvious magnetic boundary seems to follow the Totschunda strand of the Denali fault. The Eureka Creek thrust fault (Nokleberg and others, 1982), which intersects the Talkeetna thrust and is subparallel to the Denali fault, follows the same approximate trend. This fault coincides with a distinct gradient on detailed magnetic maps (D. L. 
Campbell, U.S. Geological Survey, written commun., April 1984), separating either thicker and(or) more magnetic rocks on the south-southwest from thinner and(or) less magnetic rock on the north-northwest. Geologic mapping (Nokleberg and others, 1982) suggests that the Eureka Creek fault separates the Slana River and Tangle subterranes of Wrangellia.

Figure $50 \mathrm{~B}$ shows a Bouguer gravity map with superimposed fault and terrane data. The dashed contours are approximately located using geologic and topographic data (as in the $-130 \mathrm{mGal}$ low near the center of the map) and should be used with caution. The Talkeetna thrust fault is aligned along groups of parallel contours, indicating that a distinct gravity gradient is associated with it. In contrast, the Denali fault crosses many gravity contours at large angles or borders the edge of parallel contour groups, suggesting gradients on either side of the fault but not coincident with it. Detailed gravity profiles have now been made across the Denali fault system at several places, and none shows a distinct gravity gradient. However, along the trace of the fault, large changes in Bouguer anomaly value and a total gravity relief exceeding 70 mgals are observed. The lack of a distinct gravity gradient across the fault coupled with the large variation in gravity along it seems inconsistent with postulated large strike-slip displacement on a steeply dipping transform fault, though the data may be otherwise explained. Several detailed profiles across the fault show narrow gravity lows thought to represent fractured rocks or Cenozoic sediments filling erosional or structural depressions (Barnes and Morin, 1975). The largest of these gravity lows is west of the area of figure 50, where it represents a narrow structural depression in the Holitna basin (Barnes, 1977). Such expression is more consistent with vertical or complex reversal of motion leading to fracturing of the adjacent rocks. The Totschunda fault is marked by a gravity gradient best shown on a terrain-corrected version of the data in the Nabesna Quadrangle (Barnes and Morin, 1975). Similarly, the Eureka Creek fault is shown by a distinct gradient marking two gravity highs, representing a thickening of the dense volcanic and underlying ultramafic rocks in the Tangle subterrane of Wrangellia (Campbell, 1984).

A final piece of data comes from the unreversed seismic refraction survey made by the the Carnegie Institute in 1955 and later interpreted by Hales and Asada (1966). Seismic arrivals from shots fired in College Fiord were recorded along the Richardson Highway, which crosses the Eureka Creek thrust and Denali fault east of the junction with the Talkeetna, Hines Creek, and McKinley faults. Hales and Asada considered the Richardson Highway arrivals clear and distinct, but they were puzzled by a 1-sec delay in arrival of the $6.8 \mathrm{~km} / \mathrm{sec}$ Pn wave between recording stations at distances of 223 and $262 \mathrm{~km}$ from the shot point, an interval which crosses the trace of the Eureka Creek thrust. No similar delay was recorded at the crossing of the Denali fault, and similar velocities were indicated by at least three stations both north and south of the 223-262 km interval. Geophysical data and the geologic maps of the Eureka Creek thrust obtained more recently may offer a possible explanation. Csejtey and others (1982) suggest that the Talkeetna thrust emplaces high-velocity volcanic rocks over lower velocity flysch sequences; the Eureka Creek thrust may be a similar feature. The 1-sec delay could be accounted for if the velocity of the sedimentary rocks is $1 \mathrm{~km} / \mathrm{sec}$ lower than that of the overlying volcanic rocks and the energy traveled through as much as $5 \mathrm{~km}$ of either unit. Also, if one phase of the first arrival was missed on the northern records, the sediments below the Eureka Creek thrust may offer an explanation for the increased attenuation. Reversed seismic refraction measurements planned for TACT will test these explanations and account for the comparative lack of geophysical signature of the Denali fault in contrast to the Talkeetna and Totschunda faults.

\section{REFERENCES CITED}

Barnes, D. F., 1977, Bouguer gravity map of Alaska: U.S. Geological Survey Geophysical Investigations Map GP-913, 1 sheet, scale $1: 2,500,000$.

Barnes, D. F., and Morin, R. L., 1975, Gravity map of the Nabesna Quadrangle, Alaska: U.S. Geological Survey Miscellaneous Field Studies Map MF-655-I, 1 sheet, scale 1:250,000.

Campbell, D. L., 1984, Geophysical constraints on structural interpretations of accreted terranes, south-central Alaska: Geological Society of America Abstracts with Programs, v. 16 , no. 4 , p. 274.

Csejtey, Bella, Jr., Nelson, W. H., Jones, D. L., Silberling, N. J., Dean, R. M., Morris, M. S., Lanphere, M. A., Smith, J. G., and Silberman, M. L., 1978, Reconnaissance geologic map and geochronology, Talkeetna Mountains Quadrangle, northern part of Anchorage Quadrangle, and southwest corner of the Healy Quadrangle, Alaska: U.S. Geological Survey Open-File Report 78-558A, 60 p., and map, scale $1: 250,000$.

Csejtey, Béla, Jr., Cox, D. P., Evarts, R. C., Stricker, G. D., and Foster, H. L., 1982, The Cenozoic Denali fault system and the Cretaceous accretionary development of southern Alaska: Journal of Geophysical Research, v. 87, no. B5, p. 3741-3754.

Csejtey, Bela Jr., Mullen, M. W., and Foster, H. L., 1983, Tectonostratigraphic terranes versus $\mathrm{fa}^{-}$ cies changes in the central Alaska Range: Geological Society of America Abstracts with Programs, v. 15, no. 5, p. 428. 
Godson, R. H. (principal compiler), 1982, Composite magnetic anomaly map of the United States, Part B: Alaska and Hawaii: Society of Exploration Geophysicists and U.S. Geological Survey Open-File Report 82-970, 20 p.g 1 sheet, scale $1: 2,500,000$.

Forbes, R. B., Turner, D. L., Stout, James, and Smith, T. E., 1973, Cenozoic offset along the Denali fault, Alaska abs.: EOS (American Geophysical Union Transactions), v. 54, no. 4, p. 495 .

Hales, A. L., and Asada, Toshi, 1966, Crustal structure in coastal Alaska, in Steinhart, J. S., and Smith, T. J., eds., The Earth Beneath the Continents: American Geophysical Union Geophysical Monograph 10, p. 420-432.

Nokleberg, W. J., Albert, N. R. D., Bond, G. C., Herzon, P. L., Miyaoka, R. T., Nelson, W. H., Richter, D. H., Smith, T. E., Stout, J. H., Yeend, Warren, and Zehner, R. E., 1982, Geologic map of the southern part of the Mount Hayes Quadrangle, Alaska: U.S. Geological Survey Open-File Report 82-52, 26 p., 1 map, scale 1:250,000

Mendenhall, W. C., 1905, Geology of the central Copper River region, Alaska: U.S. Geological Survey Professional Paper 41, 133 p.

St. Amand, Pierre, 1957, Geological and geophysical synthesis of the tectonics of portions of British Columbia, the Yukon Territory, and Alaska: Geological Society of America Bulletin, v. 68 , no. 10 , p. 1343-1370.

Wahrhaftig, Clyde, Turner, D. L., Weber, F. R., Smith, T. E., 1975, Nature and timing of movement on Hines Creek strand of Denali fault system, Alaska: Geology, v. 3, no. 8, p. $463-466$.

Reviewers: D. L. Campbell and Clyde Wahrhaftig

\section{MAGNETIC PROFILE ACROSS DENALI FAULT, MOUNT HAYES QUADRANGLE, EASTERN ALASKA RANGE}

\section{by David L. Campbell and Warren J. Nokleberg}

The Denali fault, a major structural feature of southern Alaska and adjacent Canada, has been interpreted as a strike-slip fault with right-lateral displacement of $400 \mathrm{~km}$ since Cretaceous time (Forbes and others, 1974; W. J. Nokleberg;, D. L. Jones, and N. J. Silberling, written commun., 1984). In the eastern Mount Hayes Quadrangle, the Denali fault coincides with a boundary on the aeromagnetic map (State of Alaska, 1974) that separates regions with low magnetic fields on the north from those with high magnetic fields on the south. There, the Denali fault separates the Jarvis Creek Glacier and Windy terranes to the north from Wrangellia and smaller terranes to the south (Nokleberg and others, 1982; W. J. Nokleberg, D. L.
Jones, and N. J. Silberling, written commun., 1984). The Jarvis Creek Glacier terrane (W. J. Nokleberg, D. L. Jones, and N. J. Silberling, written commun., 1984) consists of fine-grained, polydeformed schist that can be subdivided into two major components: (1) a metasedimentary rock component and (2) a metavolcanic rock component that contains moderate amounts and various types of metasediments. Both members are cataclastically deformed and regionally metamorphosed under greenschist-facies conditions into mylonitic schist and local phyllonite.

The Wrangellia terrane (Jones and others, 1981) is composed predominantly of late Paleozoic island arc rocks disconformably overlain by massive subaerial basalt flows of the Triassic Nikolai Greenstone and locally by younger rocks of Mesozoic and Tertiary age. Wrangellia is locally intruded by small to moderate-sized granitic plutons, some having tentative $\mathrm{K}-\mathrm{Ar}$ dates corresponding to Late Jurassic to Late Cretaceous ages (Turner and Smith, 1974). A large pluton of quartz monzonite and granodiorite underlies the Rainbow Mountain area, though much of this pluton is hidden by surficial deposits and by rocks thrust over it along the McCallum Creek fault and related faults (W. J. Nokleberg, D. L. Jones, and N. J. Silberling, written commun., 1984). This pluton is part of a regional batholith, herein termed the Gulkana batholith, whose existence we infer from the aeromagnetic map. The Gulkana batholith appears from its aeromagnetic signature to be trimmed on the north by the Denali fault. It extends for approximately 40 $\mathrm{km}$ along and approximately $12 \mathrm{~km}$ to the south of the Denali fault (fig. 51).

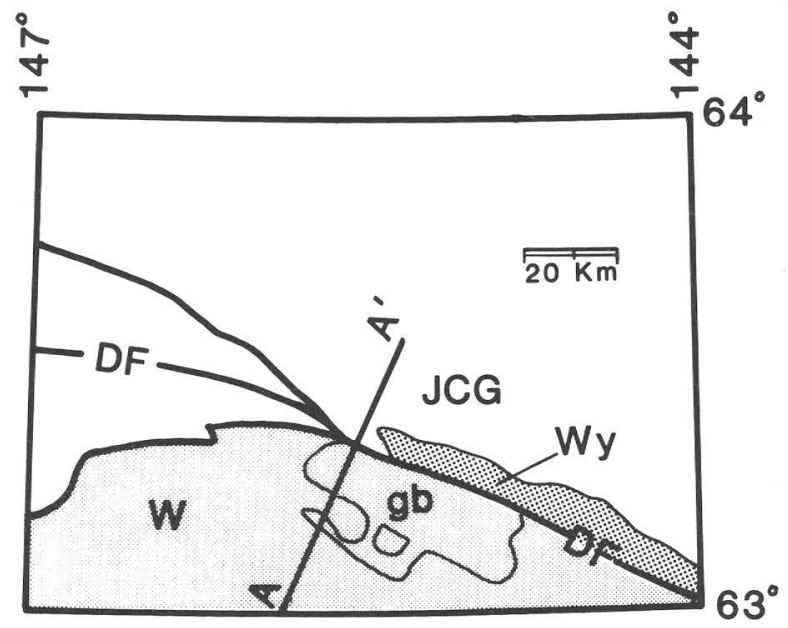

Figure 51.--Outline map of Mount Hayes Quadrangle showing location of profile $\mathrm{A}-\mathrm{A}^{\prime}$ and boundaries of terranes mentioned in the text. Other terranes and subterranes are present but not shown in the figure. W, Wrangellia terrane; JCG, Jarvis Creek Glacier terrane; Wy, Windy terrane; DF, Denali fault; gb, Gulkana batholith. 


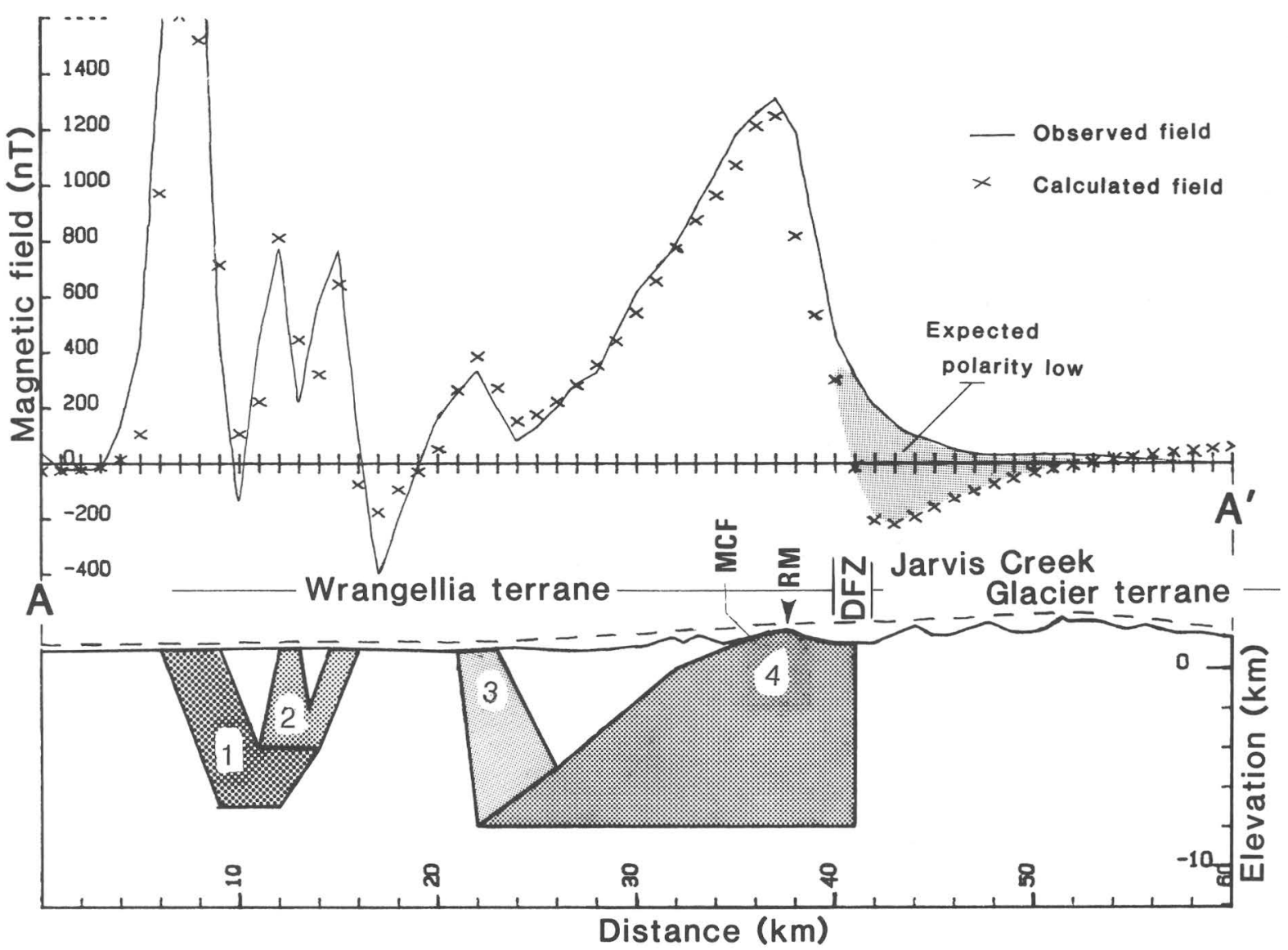

Figure 52.--Magnetic model of profile A-A' showing that a polarity low (shaded) should occur if the Gulkana batholith (body 4 ) is truncated vertically by the Denali fault. At this location, the Denali fault is covered by a glacier, but its surface location is known to be within the Denali fault zone (DFZ). RM, Rainbow Mountain; MCF, McCallum Creek fault.

Figures 52 and 53 show models of possible magnetic structures along profile $\mathrm{A}-\mathrm{A}^{t}$ (fig. 51), which trends magnetic north (N. $28^{\circ}$ E.) across the Gulkana batholith and Denali fault. Observed magnetic fields along this profile were taken from the aeromagnetic map of the Mount Hayes Quadrangle (State of Alaska, 1974). All bodies are supposed magnetized in the direction of the Earth's present field, of $57,000 \mathrm{nT}$ magnitude, $76^{\circ}$ inclination, and $28^{\circ}$ easterly declination. The effective magnetic susceptibility used for each body is listed in table 13 and indicated on the figure by darker shading for higher susceptibilities. Unshaded portions of the section represent non-magnetic (very low susceptibility) rocks. Bodies 1 and 2 are the same on all figures and are not discussed. The bodies shown were assumed to extend perpendicular to the plane of the section for varying strike-length distances Y1 and Y2 (table 13), and then to be vertically cut off (the "2 1/2-dimensional geometry" of Shuey and Pasquale, 1973). Y1 and Y2 were chosen to match strike lengths of corresponding anomalies on the aeromagnetic map.

In figure 52, the Gulkana batholith is assumed to be approximately equidimensional in cross-section and the Denali fault is assumed to be vertical. If both of these conditions hold true, however, there should be a substantial magnetic polarity low just north of the Denali fault, but none is observed. Errors in magnetic modelling can be caused by using wrong strike lengths, by being too near the (assumed) vertically truncated ends of the bodies being modelled, by strong remanent magnetism of source bodies, or by survey aircraft not being in the assumed position. None of these possibilities explains the discrepancy. Of particular concern was the problem of survey aircraft positionthe profile crosses obliquely from one flight line to another, and logs showing true aircraft position have been lost. We chose to calculate magnetic fields on a datum (dashed line, figs. 52, 53) that drapes topography at $0.3048 \mathrm{~km}$, the nominal 


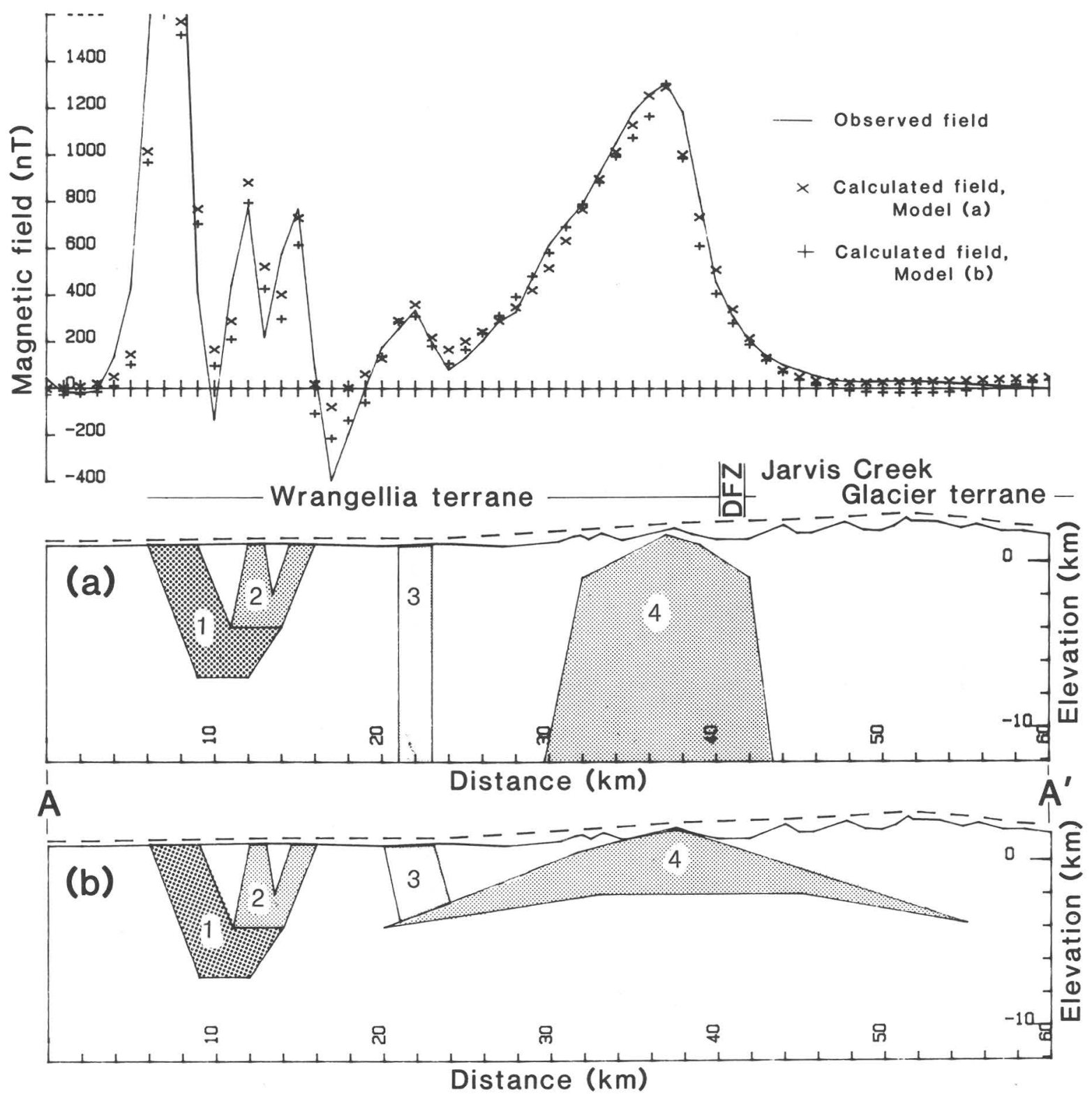

Figure 53.--Magnetic models $(\mathrm{a}, \mathrm{b})$ of profile $\mathrm{A}-\mathrm{A}^{\prime}$ showing that a good fit to the observed magnetic field can be made if it is assumed that the Gulkana batholith (body 4) extends to a great depth, as in model (a), or the Denali fault (DFZ) dips to the north at a shallow angle, as in model (b). The second alternative seems unlikely from known geology. In (a), bodies 3 and 4 extend to a depth of $40 \mathrm{~km}$ below sea level.

position of the survey aircraft, except over very rugged topography where the flight path was assumed to clear only the ridges at that distance. Fields were calculated for several other hypothetical aircraft paths besides the one shown. In all cases, a substantial polarity low was predicted.

All modelling here assumes that rocks of the Jarvis Creek Glacier terrane and the Windy terrane are nonmagnetic, a justifiable assumption. Except for a few samples from small mineralized deposits located far from profile A-A', all rock samples measured from these two terranes had susceptibilities below the threshold of our field susceptibility meter $(0.0001 \mathrm{cgs}$ units). Test models indicate that if the rocks of the Jarvis Creek Glacier terrane are uniformly magnetized, their susceptibility must be less 
Table 13.--Parameters for interpreted bodies (figures 52, 53). Gulkana batholith is inferred to be composed of quartz monzonite to granodiorite. Y1, Y2; distances bodies are assumed to extend in front of and behind the plane of the figure, respectively. Final calculations after Campbell (1983). Susc. = Magnetic susceptibility values.

\begin{tabular}{|c|c|c|c|c|c|}
\hline $\begin{array}{c}\text { Body } \\
\text { no. }\end{array}$ & $\begin{array}{l}\text { Fig. } \\
\text { no. }\end{array}$ & $\begin{array}{l}\mathrm{Y} 1 \\
(\mathrm{~km})\end{array}$ & $\begin{array}{c}\mathrm{Y} 2 \\
(\mathrm{~km})\end{array}$ & $\begin{array}{l}\text { Susc. } \\
\text { (egs) }\end{array}$ & $\begin{array}{l}\text { Rock } \\
\text { unit (s) }\end{array}$ \\
\hline 1 & $\begin{array}{l}52,53 a, \\
53 b\end{array}$ & 1 & 10 & 0.006 & $\begin{array}{l}\text { Ul tramaf ic } \\
\text { rocks }\end{array}$ \\
\hline 2 & $\begin{array}{l}52,53 a, \\
53 b\end{array}$ & 3 & 1 & 0.004 & $\begin{array}{l}\text { Ul tramaf ic } \\
\text { rocks }\end{array}$ \\
\hline 3 & $\begin{array}{l}52,53 b \\
53 a\end{array}$ & $\begin{array}{l}8 \\
8\end{array}$ & $\begin{array}{l}0.5 \\
0.5\end{array}$ & $\begin{array}{l}0.0015 \\
0.0012\end{array}$ & Dike \\
\hline 4 & $\begin{array}{l}52,53 a \\
53 b\end{array}$ & $\begin{array}{l}25 \\
25\end{array}$ & $\begin{array}{l}5 \\
5\end{array}$ & $\begin{array}{l}0.004 \\
0.007\end{array}$ & $\begin{array}{l}\text { Gulkana } \\
\text { batholith }\end{array}$ \\
\hline
\end{tabular}

than 0.0005 egs. Above this level, magnetic highs would be seen over ridges. There would still be a polarity low north of the (vertical) Denali fault, however. Instead of supposing uniformly magnetized rocks, we could hypothesize a body with higher magnetic properties juxtaposed at depth against the Denali fault. Small magnetic bodies occur elsewhere in the Jarvis Creek Glacier terrane, but there is no evidence for a larger one buried in this position. Such a body is unlikely because it would have to have a special shape in order to exactly cancel the expected polarity low there.

Figure 53 shows two interpretations that fit the observed magnetic fields: (a) the Gulkana batholith may extend to very great depths $(40 \mathrm{~km}$, in the example shown) and have steep boundaries; and (b) the bottom of the body is constrained to more shallow depths, but its boundaries must flare out at low angles. Both interpretations match observed magnetic fields, but geologically they are very different. This example shows the folly of accepting any particular magnetic model without first investigating the range of permissible source bodies. In this case, interpretations (a) and (b) represent approximate end members of a series of intermediate interpretations which could also fit the observed magnetic field.

The first interpretation implies that both the Gulkana batholith and the Denali fault extend into the lower crust. Some geologists (for example, Hamilton and Myers, 1967) believe typical batholiths are thin with respect to their widths, and so might prefer interpretation (b). However, the second interpretation requires either that the Denali fault dips at a shallow angle to the north, or that the batholith was intruded after cessation of movement on the Denali fault. Geologic mapping in this area (Nokleberg and others, 1982) shows that the Denali fault is approximately vertical near the surface. The recent intrusion hypothesis also is unlikely; Holocene igneous activity is unknown in this part of Alaska, and the Denali fault appears from geologic and seismic evidence to be active (Page, 1971; Lanphere, 1978). Furthermore, the Denali fault appears from aeromagnetic data to trim the northern edge of this batholith for a distance of at least $40 \mathrm{~km}$. We conclude that the Gulkana batholith is deeply rooted, with a shape more like that in interpretation (a).

\section{REFERENCES CITED}

Campbell, D. L., 1983, BASIC programs to calculate gravity and magnetic anomalies due to $21 / 2-$ dimensional prismatic bodies: U.S. Geological Survey Open-File Report 83-154, 37 p.

Forbes, R. B., Smith, T. E., and Turner, D. L., 1974, Comparative petrology and structure of the Maclaren, Ruby Range, and Coast Range belts-Implications for offset along the Denali fault system: Geological Society of America Abstracts with Programs, v. 6, p. 177.

Hamilton, Warren, and Myers, W. B., 1967, The nature of batholiths: U.S. Geological Survey Professional Paper 554-C, 30 p.

Jones, D. L., Silberling, N. J., Berg, H. C., and Plafker, George, 1981, Map showing tectonostratigraphic terranes of Alaska, columnar sections, and summary description of terranes: U.S. Geological Survey Open-File Report 81-793, 20 p., 2 pls.

Lanphere, M. A., 1978, Displacement history of the Denali fault system, Alaska and Canada: Canadian Journal of Earth Sciences, v. 15, p. 817-822.

Nokleberg, W. J., Albert, N. R. D., Bond, G. C., Herzon, P. L., Miyoaka, R. T., Nelson, W. H., Richter, D. R., Smith, T. E., Stout, J. H., Yeend, Warren, and Zehner, R. E., 1982, Geologic map of the southern part of the Mt. Hayes Quadrangle, Alaska: U.S. Geological Survey Open-File Report 82-52, 26 p., 1 pl.

Page, R. A., 1971, Microearthquakes on the Denali fault near the Richardson Highway, Alaska: EOS (American Geophysical Union Transactions), v. 52 , p. 278.

Shuey, R. T., and Pasquale, A. S., 1973, End corrections in potential field modelling: Geophysical Prospecting, v. 27, p. 749-760.

State of Alaska, 1974, Aeromagnetic survey, East Alaska Range, Mt. Hayes, Alaska: Alaska Division of Geological and Geophysical Surveys Map AOF-10, scale 1:250,000.

Turner, D. L., and Smith, T. E., 1974, Geochronology and generalized geology of the central Alaska Range, Clearwater Mountains and northern Talkeetna Mountains: 
Alaska Division of Geological and Geophysical Surveys Open-File Report AOF-72, 10 p.

Reviewers: C. K. Moss and W. B. Hamilton

\section{LEAD ISOTOPES IN SULFIDE DEPOSITS FROM THE JAR VIS CREEK GLACIER AND WRANGELLIA TERRANES, MOUNT HAYES QUADRANGLE, EASTERN ALASKA RANGE}

\section{by Anne P. LeHuray, Stanley E. Church, and Warren J. Nokleberg}

The Jarvis Creek Glacier terrane, which lies north of the Denali fault in the Mount Hayes Quadrangle, is a sequence of metamorphosed sedimentary, volcaniclastic, and volcanic rocks that are Devonian or older in age (Nokleberg and others, 1983). Metavolcanic rocks are not abundant in the section, but, where present, they consist largely of meta-andesite and meta-quartz keratophyres. Several massive sulfide deposits are associated with the volcanic-rich member of the Jarvis Creek Glacier terrane. Massive sulfide deposits occur in or adjacent to metamorphosed quartz keratophyre, andesite, and dacite that is interlayered with chloritequartz pelitic schist and quartzite, suggesting a submarine voleanogenic origin for these deposits. Galena from the deposits in the Jarvis Creek Glacier terrane from the southeastern part of the Mount Hayes quadrangle and lead-rich sulfide samples from massive sulfide deposits from the northwestern part of the Mount Hayes Quadrangle are very similar and have a limited range of leadisotopic compositions $\left({ }^{206} \mathrm{~Pb} /{ }^{204} \mathrm{~Pb}=18.834\right.$ 18.985; $\quad{ }^{207} \mathrm{~Pb} /{ }^{204} \mathrm{~Pb}=15.691-15.729$; and ${ }^{208} \mathrm{~Pb} /{ }^{204} \mathrm{~Pb}=38.67$ - 38.90; A, fig. 54).

The Wrangellia terrane, south of the Denali fault in the Mount Hayes Quadrangle, has been divided into the Tangle and Slana River subterranes (W. J. Nokleberg, D. L. Jones, and N. J. Silberling, written commun., 1984). The Slana River subterrane is a late Paleozoic island arc sequence containing numerous small lode deposits, some of which are associated with carbonate rocks. These deposits probably formed during remobilization of sulfides that occurred during accretion and metamorphism of the Wrangellia terrane, probably during Cretaceous time (R. C. Roback, W. J. Nokleberg, I.M. Lange, and Warren Yeend, written commun., 1984; Silberman and others, 1981). Lead-isotopic data from these deposits form a second, discrete lead-isotope field $\quad\left({ }^{206} \mathrm{~Pb} /{ }^{204} \mathrm{~Pb}=18.720-18.986\right.$; ${ }^{207} \mathrm{~Pb} /{ }^{204} \mathrm{~Pb}=15.569-15.591 ;{ }^{208} \mathrm{~Pb} /{ }^{204} \mathrm{~Pb}=38.20$ - 38.41; B, fig. 54). Lead-isotopic data from massive sulfide deposits associated with island are environments commonly have steep slopes indicating that the lead in the deposits represents a mixing of

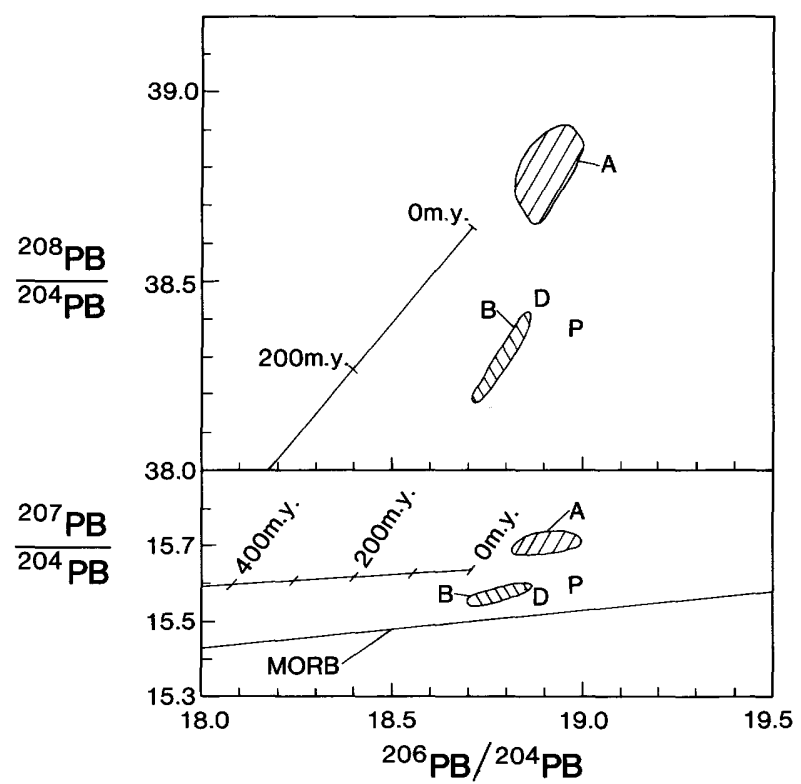

Figure 54.--Lead-isotope diagram showing the field of data for massive sulfide deposits from (A), the Jarvis Creek Glacier terrane; (B), the Slana River subterrane; (D) the Denali mine. Also shown are data from an epigenetic replacement deposit of probable late Mesozoic age from the Wrangellia terrane (P). The growth curves and the MORB regression line are included for reference.

the lead from the mantle, represented by the midocean ridge basalt (MORB) regression line (Church and Tatsumoto, 1975) and the crust (Doe and Zartman, 1979).

Upper Paleozoic and Lower Triassic sedimentary and volcanic rocks of the Slana River subterrane are unconformably overlain by the Nikolai Greenstone, a thick sequence of pillow basalts and massive subaerial basalts of Triassic age. Leadisotopic data from a massive sulfide deposit showing crossbedding and hosted in the Nikolai Greenstone at the Denali mine in the Healy Quadrangle, have a third distinetive signature $\quad\left({ }^{206} \mathrm{~Pb} /{ }^{204} \mathrm{~Pb}=18.886\right.$; ${ }^{207} \mathrm{~Pb} /{ }^{204} \mathrm{~Pb}=15.570 ;{ }^{208} \mathrm{~Pb} /{ }^{204} \mathrm{~Pb}=38.20 ; \mathrm{D}$, fig. 54). These data suggest that lead in the crustal reservoir for the massive sulfide deposits associated with the Nikolai Greenstone and in the upper Paleozoic volcanic and sedimentary rocks of the Slana River subterrane came from a crustal source having a similar history.

Late Mesozoic and early Tertiary granitic plutons intrude terranes south of the Denali fault. One sample from an epigenetic replacement deposit associated with late Mesozoic igneous activity and hosted in the Tetalna Volcanics (R. C. Roback, W. J. Nokleberg, I. M. Lange, and Warren Yeend, written commun., 1984) also has a unique lead-isotope sig- 
nature $\left({ }^{206} \mathrm{~Pb} /{ }^{204} \mathrm{~Pb}=18.986 ;{ }^{207} \mathrm{~Pb} /{ }^{204} \mathrm{~Pb}=\right.$ $15.610 ;{ }^{208} \mathrm{~Pb} /{ }^{204} \mathrm{~Pb}=38.38$; $\mathrm{P}$, fig. 54) and reflects the same crustal ${ }^{207} \mathrm{~Pb} /{ }^{204} \mathrm{~Pb}$ provenance seen in other deposits in the Wrangellia terrane. The more radiogenic ${ }^{206} \mathrm{~Pb} /{ }^{204} \mathrm{~Pb}$ and ${ }^{208} \mathrm{~Pb} /{ }^{204} \mathrm{~Pb}$ values reflect growth of radiogenic lead in the crustal reservoir between late Paleozoic and Jurassic time.

Lead-isotope data from deposits in two major crustal blocks in the Mount Hayes Quadrangle, one to the north and another to the south of the Denali fault, define distinctive lead-isotope provenances that may reflect the age of each crustal block. The lower ${ }^{207} \mathrm{~Pb} /{ }^{204} \mathrm{~Pb}$ signatures that characterize the deposits in the island arc rocks of the Slana River subterrane may be best represented by multi-cycle sediments of Paleozoic age. In contrast, the much higher ${ }^{207} \mathrm{~Pb} /{ }^{204} \mathrm{~Pb}$ signatures observed in the Devonian massive sulfide deposits of the Jarvis Creek Glacier terrane may represent first-cycle sediments derived largely from a crystalline terrane of Precambrian age.

\section{REFER ENCES CITED}

Church, S. E., and Tatsumoto, Mitsunobu, 1975, Lead isotope relations in oceanic ridge basalts from the Juan de Fuca-Gorda Ridge area, N. E. Pacific Ocean: Contributions to Mineralogy and Petrology, v. 39, p. 253-279.

Doe, B. R., and Zartman, R. E., 1979, Plumbotectonics, the Phanerozoic; in Barnes, H.L., ed., Geochemistry of Hydrothermal Ore Deposits (2d ed.): New York, WileyInterscience, p. 22-70.

Nokleberg, W. J., Aleinikoff, J. N., and Lange, I. M., 1983, Origin and accretion of Andean-type and island are terranes of Paleozoic age juxtaposed along the Hines Creek fault, Mount Hayes Quadrangle, eastern Alaska Range, Alaska: Geological Society of America Abstracts with Programs, v. 15, p. 427.

Silberman, M. L., MacKevett, E. M., Connor, C. L., and Matthews, Alan, 1981, Metallogenetic and tectonic significance of whole-rock potassium-argon ages of the Nikolai Greenstone, McCarthy Quadrangle, Alaska: U.S. Geological Survey Open-File Report 81-355, p. 52-73.

Reviewers: J. N. Aleinikoff and R. B. Tripp

\section{PETROGRAPHY OF SANDSTONE FROM THE YAEUTAT GROUP, MALASPINA DISTRICT, SOUTHERN ALASKA}

\section{by John S. Lull and George Plafker}

The Yakutat Group consists of highly deformed Jurassic(?) and Cretaceous flysch and me- lange exposed along the Gulf of Alaska margin from Haydon Peak to Lituya Bay (fig. 55). It underlies the eastern part of the Yakutat block, a small tectonostratigraphic terrane bounded on the northeast by the Fairweather dextral fault, on the northwest by the Chugach-Saint Elias thrust fault system and its of fshore extensions, and on the southwest by the Transition fault zone (Plafker and others, 1978; Plafker, 1983). The Yakutat block is presently moving northwestward relative to North America along the Fairweather transform fault where it is juxtaposed against coeval metamorphosed strata of the Chugach terrane.

In this study, twelve thin sections of the Yakutat Group sandstone that crops out west of Yakutat Bay were analyzed in order to place constraints on their provenance. This information supplements previous petrographic studies of sandstone from the part of the Yakutat Group that is exposed mainly to the east of Yakutat Bay (Zuffa and others, 1980; Winkler and Plafker, 1981) and a sedimentologic analysis of flysch in the study area (Nilsen and others, 1984).

Modal analyses of sandstone from the Yakutat Group west of Yakutat Bay are shown in tables 14-16. Framework grains consist of quartz and plagioclase in approximately equal amounts, felsitic and microlitic volcanic fragments averaging 14 percent of rock volume, and $\mathrm{K}$-feldspar averaging 6 percent of rock volume. Porosity is negligible in all samples.

The abundance of quartzofeldspathic detritus is indicative of a dominantly plutonic provenance (Dickinson, 1970) and, combined with the presence of intermediate volcanic detritus, indicates that the most likely source area was a dissected magmatic arc in which the plutonic roots were partly exposed. Values for framework-grain compositions plotted on ternary QFL and lithic diagrams (fig. 56) also suggest derivation from a plutonic arc-root source (Dickinson and Suczek, 1979). Low $C / Q$ values, high $\mathrm{V} / \mathrm{L}$ values, and a paucity of metamorphic lithic fragments (table 14) preclude derivation of the sandstone from predominantly metamorphic or recycled orogen sources (Dickinson, 1970; Dickinson and Suczek, 1979).

Sandstone from the study area is similar petrographically to the Yakutat Group sandstone described by Winkler and Plafker (1981) from the area southeast of Yakutat Bay (figs. 55; table 16), suggesting that the Upper Cretaceous flysch of the Yakutat Group is compositionally homogeneous. However, sandstone of the Yakutat Group differs from coeval flysch-like sandstone of the Chugach terrane, where volcanic lithic detritus is generally more abundant (Winkler and Plafker, 1981; Zuffa and others, 1980; Nilsen and Zuffa, 1982). Although much of the sandstone in the Chugach terrane must have been derived from a volcanic arc source, the lithic components indicate a tendency for an increase in the degree of arc dissection from west to 

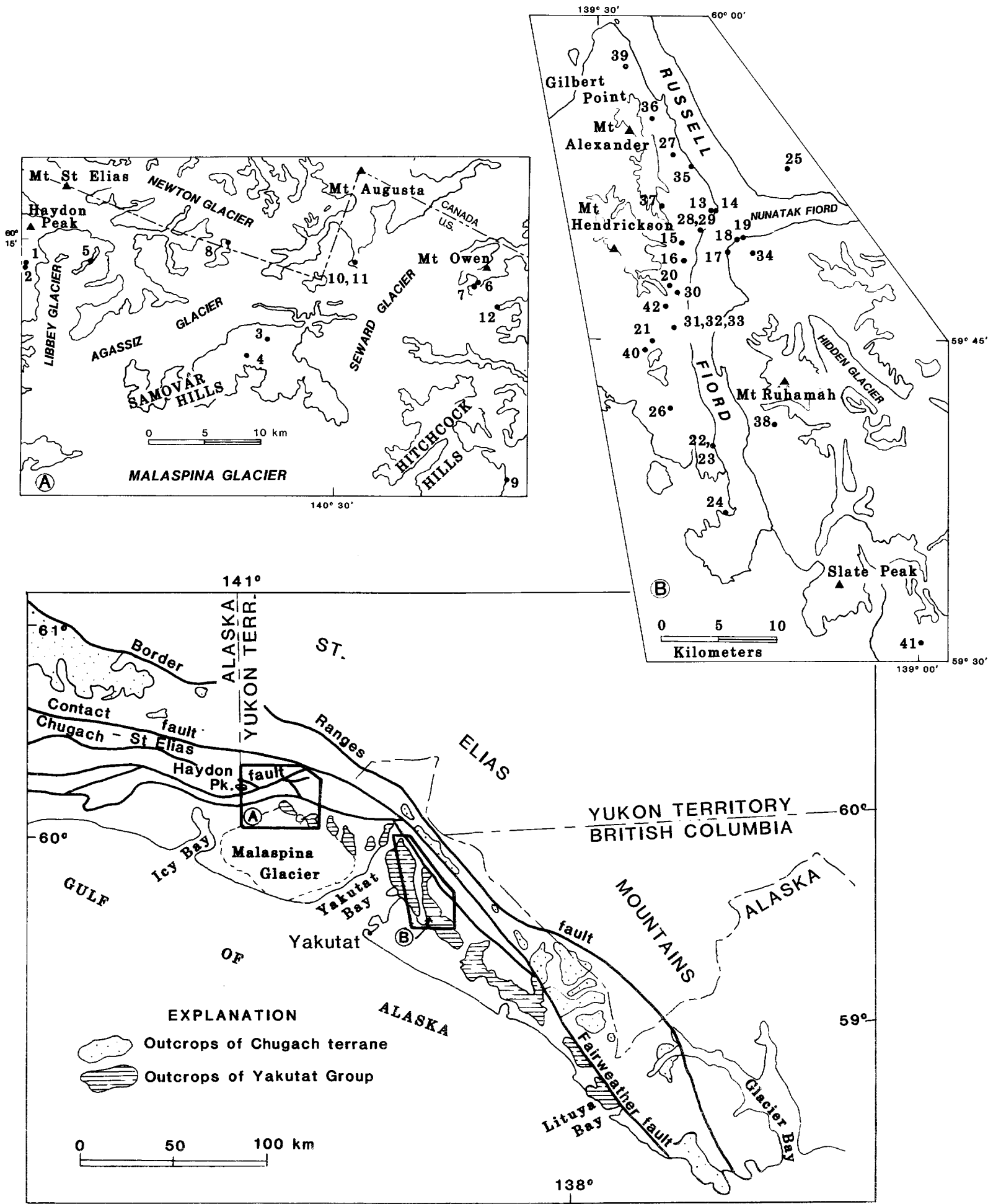

Figure 55.--Map showing outcrop localities of the Chugach terrane and the Yakutat Group and faults in part of southern Alaska. Outlines show sample locations in the (A) Malaspina and (B) Yakutat districts. Numbers correspond to sample numbers on tables 15 and 16, respectively. 


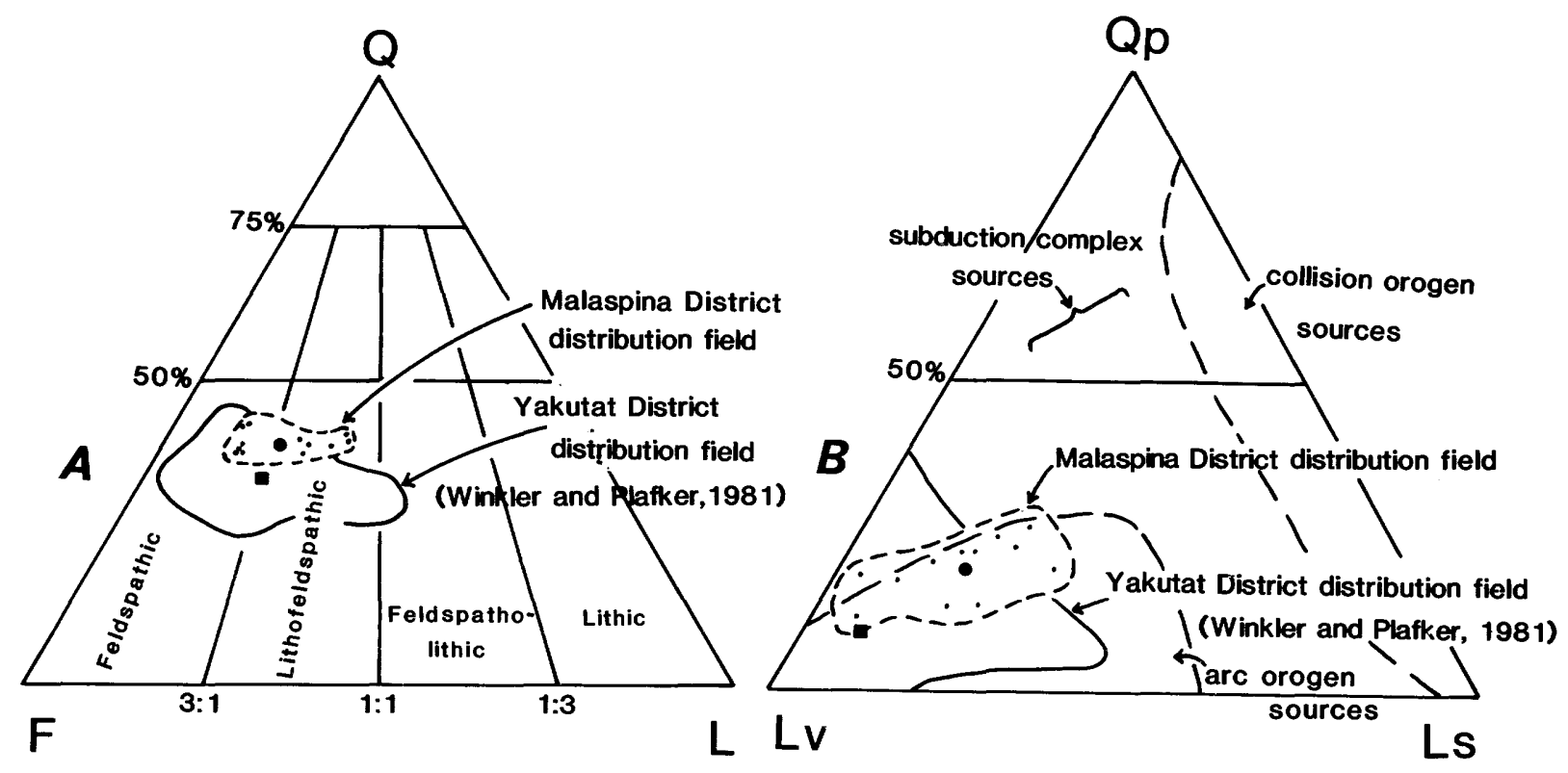

Figure 56.--Results of petrographic analyses of Malaspina and Yakutat district sandstones of the Yakutat Group. Malaspina district samples are plotted and the distribution fields are indicated. Yakutat district distribution fields (Winkler and Plafker, 1981) are shown. Mean grain compositions of sandstones from each district are shown in table 14, and values for all samples are reported in tables 15 and 16 . A, Ternary diagram with total quartz-feldspar-lithic end members shows that the sandstones are predominantly lithofeldspathic and feldspathic. B, Ternary diagram with polycrystalline quartz-volcanic lithic-sedimentary lithic end members indicates that the sandstones are derived from arc orogen sources. Provenance fields are from Dickinson and Suczek (1979) . Circle $=$ mean values for Malaspina district; square $=$ mean values for Yakutat district.

Table 14.--Mean grain compositions of Yakutat Group sandstones from the Malaspina and Yakutat districts; $n$, number of samples; $Q$, total quartzose grains; F, total feldspar; L, total lithic fragments; $\mathrm{P}$, plagioclase; $\mathrm{C}, \mathrm{Qp}$, polycrystalline quartzose grains; Lv, V, volcanic lithic fragments; Ls, sedimentary lithic fragments.

\begin{tabular}{lcccccccccc}
\hline District & $\mathrm{n}$ & $\mathrm{Q}$ & $\mathrm{F}$ & $\mathrm{L}$ & $\mathrm{P} / \mathrm{F}$ & $\mathrm{C} / \mathrm{Q}$ & $\mathrm{V} / \mathrm{L}$ & $\mathrm{Qp}$ & $\mathrm{Lv}$ & $\mathrm{Ls}$ \\
\hline Malaspina & 12 & 40 & 43 & 17 & .84 & .11 & .75 & 20 & 62 & 18 \\
Yakutat & 30 & 34 & 50 & 16 & .87 & .04 & .88 & 9 & 82 & 9 \\
\hline
\end{tabular}

east (Zuffa and others, 1980). If the Yakutat Group was contiguous with the Chugach terrane during the Late Cretaceous, it must have been derived from the most deeply dissected part of the volcanic arc.

Geologic evidence suggests that the Yakutat block was originally located approximately $550 \mathrm{~km}$ to the southeast and has been displaced northwestward along the Queen Charlotte-Fairweather transform fault system during the Neogene (Plafker, 1983). If so, the closest suitable provenance for the
Yakutat Group would be the Coast crystalline complex of southeastern Alaska and British Columbia.

\section{REFERENCES CITED}

Dickinson, W. R., 1970, Interpreting detrital modes of graywacke and arkose: Journal of Sedimentary Petrology, v. 40, p. 690-707.

Dickinson, W. R., and Suczek, C. A., 1979, Plate tectonics and sandstone compositions: American Association of Petroleum Geologists Bulletin, v. 63, no. 12, p. 2164-2182.

Nilsen, T. H., Plafker, George, Atwood, D. E., and Hill, E. R., 1984, Sedimentology of upper Mesozoic Yakutat Group flysch, Malaspina district, Alaska, in Reed, K. M., and BartschWinkler, Susan, eds., The United States Geological Survey in Alaska-Accomplishments during 1982: U.S. Geological Survey Circular 939 , p. 57-60.

Nilsen, T. H., and Zuffa, G. G., 1982, The Chugach terrane, a Cretaceous trench-fill deposit, southern Alaska, in Legget t, J. K., ed., Trench-forearc geology: Sedimentation and 
Table 15.-Framework gra in compositions in the Yakutat Group, Malaspina District (See table 14 for explanation of symbols.)

\begin{tabular}{|c|c|c|c|c|c|c|c|c|c|c|}
\hline $\begin{array}{l}\text { Sample } \\
\text { number }\end{array}$ & $\begin{array}{l}\text { Site } \\
\text { number }\end{array}$ & $\mathrm{Q}$ & $\mathrm{F}$ & $\mathrm{L}$ & $\mathrm{P} / \mathrm{F}$ & $C / Q$ & $\mathrm{~V} / \mathrm{L}$ & $\mathrm{Qp}$ & Lv & Ls \\
\hline $69 \mathrm{APr} 52 \mathrm{D} 3$ & 1 & 39.5 & 36.9 & 23.6 & .79 & .15 & .80 & 21.1 & 66.1 & 12.8 \\
\hline $82 \mathrm{APr} 75 \mathrm{~B}$ & 2 & 40.3 & 33.8 & 25.8 & .92 & .19 & .76 & 23.0 & 59.7 & 17.3 \\
\hline $82 \mathrm{APr} 41 \mathrm{~A}$ & 3 & 38.4 & 41.6 & 20.0 & .79 & .13 & .61 & 20.0 & 50.0 & 30.0 \\
\hline 82 A Pr71 & 4 & 39.6 & 39.8 & 20.6 & .84 & .16 & .68 & 23.9 & 53.2 & 22.9 \\
\hline $82 \mathrm{APr} 37 \mathrm{E}$ & 5 & 40.9 & 40.9 & 18.2 & .96 & .12 & .76 & 22.5 & 61.8 & 15.7 \\
\hline $69 \mathrm{APr} 35 \mathrm{~B} 2$ & 6 & 38.8 & 50.6 & 10.6 & .80 & .04 & .72 & 14.2 & 63.3 & 22.4 \\
\hline $82 \mathrm{~A} \operatorname{Pr} 27 \mathrm{~A}$ & 7 & 43.1 & 46.3 & 10.6 & .86 & .07 & .62 & 23.1 & 50.0 & 26.9 \\
\hline $82 \mathrm{APr} 77$ & 8 & 41.3 & 33.7 & 25.0 & .80 & .20 & .72 & 25.0 & 55.3 & 19.7 \\
\hline $82 \mathrm{APr} 30$ & 9 & 38.7 & 50.0 & 11.3 & .84 & .04 & .91 & 12.2 & 81.6 & 6.1 \\
\hline 79APr29 & 10 & 39.8 & 49.3 & 10.9 & .82 & .04 & .76 & 14.0 & 68.0 & 18.0 \\
\hline $79 \mathrm{APr} 25 \mathrm{~B}$ & 11 & 38.8 & 50.2 & 11.0 & .77 & .06 & .89 & 18.2 & 72.7 & 9.1 \\
\hline *69 APr35D3 & 12 & 43.4 & 47.3 & 9.3 & .99 & .05 & .97 & 18.4 & 78.9 & 2.7 \\
\hline
\end{tabular}

Table 16. - Framework gra in compositions in the Yakutat Group, Yakutat District (Symbols as in table 14; point-counted by G. R. Winkler)

\begin{tabular}{|c|c|c|c|c|c|c|c|c|c|c|}
\hline $\begin{array}{l}\text { Sample } \\
\text { number }\end{array}$ & $\begin{array}{l}\text { Site } \\
\text { number }\end{array}$ & $Q$ & F & L & $\mathrm{P} / \mathrm{F}$ & $C / Q$ & $\mathrm{~V} / \mathrm{L}$ & Qp & Lv & Ls \\
\hline $68 \mathrm{APr} 1 \mathrm{~A} 2$ & 13 & 33.0 & 51.1 & 15.9 & .81 & .06 & .81 & 11.0 & 73.0 & 16.0 \\
\hline $68 \mathrm{APr} 3 \mathrm{~A} 2$ & 14 & 29.3 & 55.3 & 15.4 & .72 & .11 & .79 & 18.3 & 68.3 & 13.4 \\
\hline $68 \mathrm{APr} 18 \mathrm{C}$ & 15 & 35.2 & 55.5 & 9.3 & .80 & .11 & .89 & 30.0 & 62.5 & 7.5 \\
\hline $68 \mathrm{APr} 20 \mathrm{~B} 1$ & 16 & 26.4 & 38.9 & 34.7 & .94 & .07 & .97 & 5.1 & 93.2 & 1.7 \\
\hline $68 \mathrm{APr} 24 \mathrm{C}$ & 17 & 36.0 & 52.5 & 11.5 & .95 & .04 & .92 & 12.2 & 82.9 & 4.9 \\
\hline 68APr26B & 18 & 27.5 & 61.1 & 11.4 & .72 & .03 & .97 & 7.3 & 92.7 & 0 \\
\hline $68 \mathrm{APr} 27 \mathrm{~A}$ & 19 & 44.8 & 48.3 & 5.9 & .70 & .02 & .80 & 13.6 & 72.7 & 13.7 \\
\hline $68 \mathrm{APr} 30 \mathrm{~A}$ & 20 & 36.3 & 58.2 & 5.5 & .92 & .03 & 1.00 & 14.3 & 85.7 & 0 \\
\hline $68 \mathrm{APr} 33 \mathrm{~A}$ & 21 & 32.4 & 57.8 & 9.8 & .89 & .03 & .93 & 10.0 & 86.6 & 3.4 \\
\hline $68 \mathrm{APr} 40 \mathrm{C} 1$ & 22 & 39.4 & 45.9 & 14.7 & .79 & .03 & .93 & 6.7 & 88.9 & 4.4 \\
\hline $68 \mathrm{APr} 40 \mathrm{C} 2$ & 23 & 28.8 & 52.6 & 18.6 & .84 & .08 & .88 & 10.6 & 80.3 & 9.1 \\
\hline $68 \mathrm{APr} 41 \mathrm{D}$ & 24 & 39.8 & 50.7 & 9.5 & .82 & .07 & .82 & 24.4 & 65.9 & 9.7 \\
\hline $68 \mathrm{APr} 57 \mathrm{~A} 3$ & 25 & 34.4 & 63.2 & 2.4 & .99 & .04 & .83 & 37.5 & 62.5 & 0 \\
\hline 68APr64E & 26 & 31.7 & 61.9 & 6.4 & .73 & 0 & .85 & 0 & 85.0 & 15.0 \\
\hline $68 \mathrm{APr} 75 \mathrm{C}$ & 27 & 32.8 & 55.8 & 11.3 & .83 & .01 & .97 & 2.5 & 95.0 & 2.5 \\
\hline 68APs1A1 & 28 & 28.7 & 32.8 & 38.5 & .98 & .12 & .50 & 8.3 & 46.2 & 45.4 \\
\hline $68 \mathrm{APs} 1 \mathrm{~A} 3$ & 29 & 29.4 & 45.0 & 25.6 & .96 & .02 & .86 & 2.5 & 85.2 & 12.3 \\
\hline 68A Ps7 A2 & 30 & 29.6 & 53.1 & 17.3 & .91 & .01 & .91 & 1.8 & 89.3 & 8.9 \\
\hline $68 \mathrm{APs} 9 \mathrm{C} 1$ & 31 & 29.2 & 55.8 & 15.0 & .90 & .02 & .96 & 3.8 & 94.3 & 1.9 \\
\hline $68 \mathrm{APs} 9 \mathrm{C} 2$ & 32 & 30.4 & 49.1 & 20.6 & .89 & .04 & .96 & 5.7 & 91.4 & 2.9 \\
\hline $68 \mathrm{APs} 9 \mathrm{C} 3$ & 33 & 42.4 & 41.5 & 16.1 & .89 & .02 & .96 & 5.3 & 91.1 & 3.6 \\
\hline $68 \mathrm{APs} 17 \mathrm{~A}$ & 34 & 31.2 & 53.1 & 15.7 & .92 & .02 & .88 & 3.8 & 88.7 & 7.5 \\
\hline $68 \mathrm{APs} 24 \mathrm{G}$ & 35 & 35.2 & 44.4 & 20.4 & .92 & .04 & .88 & 6.9 & 83.4 & 9.7 \\
\hline 68APs27D & 36 & 41.6 & 40.0 & 18.4 & .96 & .01 & .90 & 1.8 & 91.2 & 7.0 \\
\hline 68APs34B & 37 & 33.3 & 35.8 & 30.9 & .83 & .04 & .76 & 3.8 & 73.1 & 23.1 \\
\hline 68APs $47 \mathrm{~A}$ & 38 & 25.1 & 55.4 & 19.6 & .90 & .01 & 1.00 & 1.9 & 98.1 & 0 \\
\hline 68APs53B & 39 & 40.3 & 40.9 & 18.8 & .83 & .02 & .80 & 4.4 & 77.9 & 17.6 \\
\hline 68APs72C & 40 & 32.5 & 54.2 & 13.3 & .88 & .01 & .98 & 2.2 & 95.6 & 2.2 \\
\hline 68APs81E1 & 41 & 44.7 & 48.7 & 6.6 & .89 & 0 & .85 & 0 & 89.5 & 10.5 \\
\hline $69 \mathrm{APr} 19 \mathrm{C} 1$ & 42 & 38.9 & 49.5 & 11.6 & .92 & .04 & .94 & 10.5 & 84.2 & 5.3 \\
\hline
\end{tabular}


tectonics on modern and ancient active plate margins: Geological Society of London Special Publication 10, p. 213-227.

Plafker, George, 1983, The Yakutat block: an actively accreting tectonostratigraphic terrane in southern Alaska: Geological Society of America Abstracts with Programs, v. 15, no. 5, p. 406 .

Plafker, George, Hudson, Travis, Bruns, Terry, and Rubin, Meyer, 1978, Late Quaternary offsets along the Fairweather fault and crustal plate interactions in southern Alaska: Canadian Journal of Earth Sciences, v. 15, no. 5, p. 805-816.

Winkler, G. R., and Plafker, George, 1981, Tectonic implications of framework grain mineralogy of sandstone from the Yakutat Group, in Albert, N. R. D., and Hudson, Travis, eds., The United States Geological Survey in Alaska-Accomplishments during 1979: U.S. Geological Survey Circular 823-B, p. B68B70.

Zuffa, G. G., Nilsen, T. H., and Winkler, G. R., 1980, Rock-fragment petrography of the Upper Cretaceous Chugach terrane, southern Alaska: U.S. Geological Survey Open-File Report 80-713, 28 p.

Reviewers: T. H. Nilsen and G. R. Winkler

\section{VOLCANOGENIC MASSIVE SULFIDE OCCURRENCES, \\ JARVIS CREEK GLACIER TERRANE, WESTERN MOUNT HAYES QUADRANGLE, EASTERN ALASKA RANGE \\ by Warren J. Nokleberg and lan M. Lange}

During geologic and mineral resource assessment studies of the Mount Hayes Quadrangle, several volcanogenic massive sulfide occurrences were discovered in the Jarvis Creek Glacier terrane in the western Mount Hayes Quadrangle (fig. 57). The Jarvis Creek Glacier terrane is north of the Hines Creek fault; south of the Hines Creek fault are the Hayes Glacier, Aurora Peak, and Giddings terranes (fig. 57). In the western part of the quadrangle, the Jarvis Creek Glacier terrane consists mainly of an intensely deformed and metamorphosed former marine sequence of chlorite-feldspar schist derived from intermediate volcanic rocks and has lesser amounts of interlayered pelitic schist, quartzite, and marble (Nokleberg and others, 1983; Lange and Nokleberg, 1984). Recent $\mathrm{U} / \mathrm{Pb}$ zircon isotopic studies indicate extrusion of the volcanic protoliths at about 370 m.y., or during middle Devonian time (Nokleberg and others, 1983). This metavolcanic rock-rich part of the Jarvis Creek Glacier terrane probably correlates with the Totatlanika Schist which crops out to the west in the Healy Quadrangle; this unit also contains abundant former intermediate volcanic rocks (Wahrhaftig, 1968). In the western Mount Hayes Quadrangle, at least five small to moderate-size massive sulfide occurrences are either in or adjacent to metavolcanic rocks of the Jarvis Creek Glacier terrane that crop out in two districts, the Hayes district to the west and the McGinnis Glacier district to the east (site nos. 1-5; fig. 57, table 17). About ten similar deposits and occurrences in similar rocks in the eastern part of the quadrangle have been briefly reported on by Nauman and others (1980) and Lange and Nokleberg (1984).

The Hayes district contains the Miyaoka occurrence west of the Hayes Glacier and several smaller occurrences east of the glacier (site nos. 13 ; fig. 57, table 17). The occurrences generally consist of massive pyrite and pyrrhotite and minor chalcopyrite, sphalerite, and galena that are distributed in lenses, pods, and stringers. The lenses and pods contain stringers and pod-shaped schistose aggregates of quartz, chlorite, actinolite, epidote, and carbonate. Local late-stage carbonate veinlets crosscut the sulfide lenses and pods. Host rocks for the occurrences are mainly locally graphitic muscovite-chlorite-quartz schist derived from shale, calcschist derived from marl, chlorite-feldspar schist derived from volcanic graywacke, siltstone, tuffs or flows, sparse greenstone derived from diabase or basalt, and sparse marble derived from calcite limestone or from calcareous precipitates formed on the sea floor during submarine volcanism. Original igneous compositions of the tuffs and flows were quartz-rich keratophyre, andesite, dacite, and lesser rhyodacite. Characteristics of the occurrences in the Hayes district are given in table 17.

Throughout the district, sulfide lenses and pods strike west-northwest and dip moderately south, parallelling the schistosity and foliation in the enclosing metavolcanic and metasedimentary rocks. Smaller sulfide pods and lenses, up to a few centimeters thick, also occur discontinuously in quartz-mica schist. Several sulfide layers or lenses probably were present originally, but intense deformation dismembered and contorted them, resulting in both thickening and thinning or in elimination of the formerly continuous sulfide layers. The metavolcanic and metasedimentary rocks also exhibit changes in thickness because of intense deformation.

The McGinnis Glacier district occurs in an east-facing cirque approximately $16 \mathrm{~km}$ southeast of the Hayes district (site nos. 4-5; fig. 57, table 17. One occurrence is towards the west at the top of a major cirque at $7,700 \mathrm{ft}$ elevation; the other occurrence is about $1 \mathrm{~km}$ to the east along the south wall of the cirque at $7,200 \mathrm{ft}$ elevation. The occurrences generally consist of massive pyrite, pyrrhotite, sphalerite, chalcopyrite, and galena that are distributed in tectonic lenses and pods. Gangue minerals are schistose aggregates of quartz, chlorite, epidote, biotite, actinolite, and sparse carbonate. Host rocks are mainly intensely deformed 


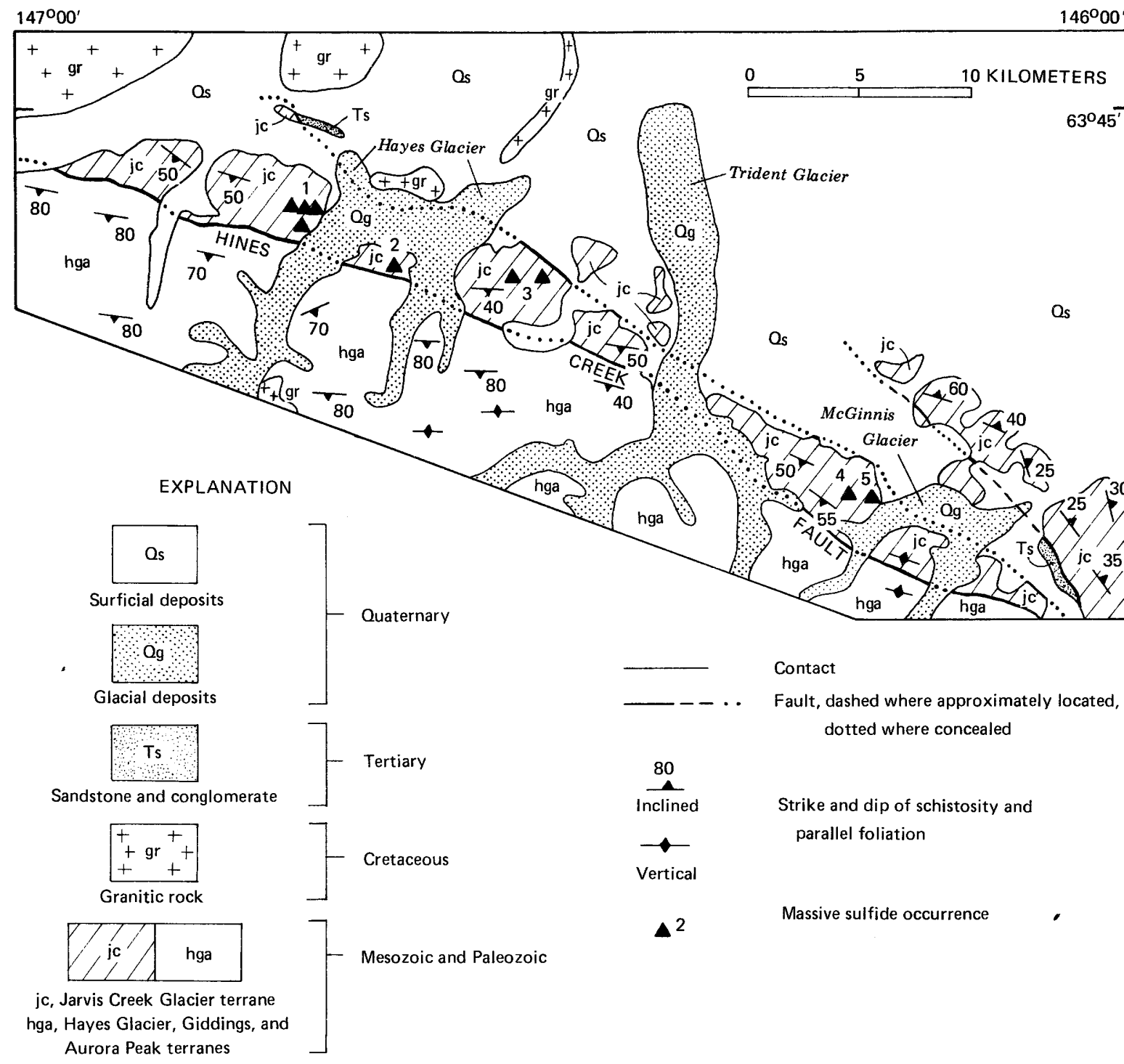

Figure 57.-Simplified geologic map of parts of the Mount Hayes C-4 to C-6 Quadrangles, eastern Alaska Range. Numbered spots indicate location of volcanogenic massive sulfide occurrences in the Hayes and McGinn is Glacier districts.

chlorite-feldspar schist derived from volcanic graywacke or quartz keratophyre, andesite, and dacite tuff or flows, locally graphitic chlorite-quartz schist derived from quartz-rich shale, calc-schist derived from marl, and massive gray marble derived from limestone. The western occurrence, inaccessible by foot, was observed indirectly from a helicopter and in large angular blocks in downslope talus. Characteristics of the two occurrences in the McGinnis Glacier district are given in table 17.

At both occurrences in the McGinnis Glacier district, the sulfide layers strike west-northwest and dip moderately southwest, parallelling schistosity and foliation in the host rocks. In both occurrences, the sequence of units is: (1) graphite-quartzcalcite schist and metavolcanic schist in the hanging wall; (2) sulfide lenses and pods forming the mineralized zone; and (3) chlorite-feldspar schist, chlorite-quartz schist, and marble in the footwall. Locally, the sulfide lenses and pods at the eastern occurrence are locally tectonically thinned or thickened in several areas and locally pinch out along strike to the west in the cirque wall. Sparse occurrences of metamorphosed, but less deformed diorite 
Table 17.--Massive sulfide occurrences, Jarvis Creek Glacier terrane, western Mount Hayes Quadrangle, eastern Alaska Range

\begin{tabular}{lll}
\hline $\begin{array}{l}\text { Map no. Host rocks } \\
\text { Name }\end{array}$ & $\begin{array}{c}\text { Maximum metal } \\
\text { concentration } \\
(\mathrm{ppm})\end{array}$ & General description \\
\hline
\end{tabular}

Hayes district

1. Metavol canic schist, Mi yaoka chlorite-quartz sch ist, and minor marble, calc-sch is t

2. Metavolcanic schist, Unnamed chlorite-quartz-epidote schist, calc-sch ist
$\mathrm{Zn}, 5,000$; $\mathrm{Cu}, 4,300$;

$\mathrm{Pb}, 170 ; \mathrm{Sn}, 50$;

$\mathrm{Au}, .20 ; \mathrm{Co}, 500$

$\mathrm{Pb}, 7,200 ; \mathrm{Zn}, 6,900$;

Ag, 5; As, 5, 000;

$\mathrm{Sn}, 100 ; \mathrm{Au}, .20$
3.

Unnamed

Metavol canic schist, chlor ite-quartz-epidote schist, calc-sch ist
$\mathrm{Cu}, 9,200 ; \mathrm{Zn}, 2,150$

$\mathrm{Pb}, 600 ; \mathrm{Ag}, 10$

Massive pyrite, pyrrhotite, and minor chalcopyrite, sphalerite, and galena in lenses and veins. About 20 lenses and pods, as much as $2 \mathrm{~m}$ thick and several meters in length along a strike length of about $2,300 \mathrm{~m}$

Massive pyrite, galena, sphalerite, and minor schist, chalcopyrite in discontinuous lenses and pods. About 5 lenses and pods as much as $20 \mathrm{~cm}$ thick, are exposed for as much as $1 \mathrm{~m}$ along strike.

Sulfide lenses and pods occur in three horizons separated by a minimum of $7 \mathrm{~m}$ of host rock

Grab samples with pyrite, pyrrhotite, sphalerite, and galena. About 5 lenses and pods, as much as $20 \mathrm{~cm}$ thick, exposed for as much as $1 \mathrm{~m}$ along strike. Lenses and pods occur in two areas $1,200 \mathrm{~m}$ apart

MeGinnis Glacier district

$\begin{array}{lll}\text { 4. } & \text { Metavolcanic sch ist, } & \mathrm{Zn}, 23,000 ; \mathrm{PD}, 320 \text {; } \\ \text { Western } & \text { chlor i te-quartz schist, } & \mathrm{Ou}, 2,600 ; \mathrm{Sn}, 70\end{array}$ quartz schist, marble
5. Chlor i te-quartz schist, Eastern marble, calc-sch ist, metavolcanic schist

$\mathrm{Pb}, 2,500 ; \mathrm{Zn}, 2,000$;

$\mathrm{Ag}, 50 ; \mathrm{Cu}, 2,500$; $\mathrm{Sn}, 30$
Massive pyrite, pyrrhotite, sphalerite, chal copyrite, and galena in massive sulfide pods pods and lenses; dimensions similar to Eastern occurrence

Grab samples of massive pyrite, pyrrhotite sphalerite, galena, and chalcopyrite in pods and lenses. About 7-10 bouldersized tectonic fragments in outerop area of $50 \mathrm{~m}$ strike length by a few $\mathrm{m}$ wide and gabbro dikes crosscut the host rocks.

The metamorphic and deformational histories of both the host rocks and massive sulfide occurrences are similar for the Hayes and McGinnis Glacier districts. Both are intensely deformed; former bedding is almost totally transformed by shearing and penetrative cataclasis into a foliation defined by dismembered lenses or isoclines. An intensely developed schistosity occurs parallel to foliation; intense cataclasis along the schistosity is indicated by fluxion structure and abundant fractured, granulated, and rolled porphyroclasts or augen of quartz, feldspar, and garnet. Abundant isoclinal folds formed in foliation occur parallel to the schistosity and fluxion structure, indicating at least two periods of intense deformation. Chlorite formed along the 
schistosity replaces biotite and, locally, sparse hornblende, indicating retrograde metamorphism from amphibolite facies to lower or middle greenschist facies during formation of the schistosity and fluxion structure. Micas in the schists are folded into small crenulations, indicating a later, weaker deformation.

Field, petrographic, chemical, and isotopic data indicate that these massive sulfide occurrences formed in Devonian time in a submarine island arc environment (Lange and Nokleberg, 1984). The submarine origin is indicated by interlayering of the metavolcanic rocks and sulfide lenses and pods with former shale, siltstone, quartzite, and marl. However, preliminary lead isotopic studies on sulfides samples from these deposits indicate a component of first cycle sediments derived largely from a Precambrian crystalline terrane (LeHuray and others, this volume).

\section{REFERENCES CITED}

LeHuray, A. P., Church, S. E., and Nokleberg, W. J., 1985, Lead isotopes in massive sulfide deposits from the Jarvis Creek Glacier and Wrangellia terranes, Mount Hayes Quadrangle, eastern Alaska Range, Alaska: this volume.

Lange, I. M., and Nokleberg, W. J., 1984, Massive sulfide deposits of the Jarvis Creek Glacier terrane, Mount Hayes Quadrangle, eastern Alaska Range, Alaska (abs.): Geological Society of America Abstracts with Programs, v. 16, p. 294 .

Nauman, C. R., Blakestad, R. A., Chipp, E. R., and Hoffman, B. L., 1980, The north flank of the Alaska Range, a newly discovered volcanogenic massive sulfide belt (abs.): Geological Association of Canada Program with Abstracts, p. 73.

Nokleberg, W. J., Aleinikoff, J. N., and Lange, I. M., 1983, Origin and accretion of Andean-type and island arc terranes of Paleozoic age juxtaposed along the Hines Creek fault, Mount Hayes Quadrangle, eastern Alaska Range, Alaska (abs.): Geological Society of America Abstracts with Programs, v. 15, no. 5 , p. 427.

Wahrhaftig, Clyde, 1968, Schists of the central Alaska Range: U.S. Geological Survey Bulletin 1254-E, p. E1-E22.

Reviewers: J. P. Albers and D. P. Cox

THE COLUMBIA BAY EARTHQUAKES OF 1983

\section{by Robert A. Page, Christopher D. Stephens, Kent A. Fogleman, and Richard P. Maley}

On July 12 and September 7, 1983, two magnitude 6 earthquakes shook southern coastal Alaska. The shocks originated near Columbia Bay on the north edge of Prince William Sound and are the largest to have occurred in the Prince William Sound region since the magnitude 9.2 (moment magnitude) earthquake of 1964 . Because of their remote location from any community, the earthquakes caused only slight damage; however, they produced the largest ground acceleration recorded from any Alaskan earthquake since strong-motion recording began in Alaska after the 1964 shock. The earthquakes were generated by predominantly normal slip on a steeply northwest-dipping, northeast-trending fault that is surmised to lie in the upper part of the subducted Pacific plate.

Using arrival times of seismic waves recorded by the southern Alaska regional seismograph network, the earthquake foci were located to an estimated accuracy of better than $3-5 \mathrm{~km}$ (table 18). Seismic travel times to the regional stations were calibrated using well-located aftershocks recorded by portable seismographs deployed in and around the epicentral area following both earthquakes. The July earthquake occurred at a depth of $30 \mathrm{~km}$, about $45 \mathrm{~km}$ west of Valdez and about $145 \mathrm{~km}$ east of Anchorage. (See fig. 60, Stephens and others, this volume.) The September shock originated $10 \mathrm{~km}$ southwest of the July earthquake, also at a depth of $30 \mathrm{~km}$ (figs. 58, 59). The epicenters lie approximately $25 \mathrm{~km}$ east of the focus of the great 1964 earthquake. The July and September earthquakes had comparable magnitudes (table 18).

U.S. Geological Survey geologists made aerial reconnaissance flights over the source region

Table 18.--Source parameters for the 1983 Columbia Bay main earthquakes.

\begin{tabular}{lll}
\hline Date & July 12 & Sept 7 \\
\hline $\begin{array}{l}\text { Origin time } \\
\text { (G.M.T.) }\end{array}$ & $15: 10: 03.7$ & $19: 22: 05.0$ \\
\hline Latitude & $61^{\circ} 02^{\prime} \mathrm{N}$ & $60^{\circ} 59^{\prime} \mathrm{N}$ \\
Longitude & $147^{\circ} 11^{\prime} \mathrm{W}$ & $147^{\circ} 19^{\prime} \mathrm{W}$ \\
\hline Depth & $30 \mathrm{~km}$ & $30 \mathrm{~km}$ \\
\hline $\begin{array}{l}\text { Body-wave } \\
\text { magnitude (m }\end{array}$ & $6.1^{1}$ & $6.2^{1}$ \\
\hline $\begin{array}{l}\text { Surface-wave } \\
\text { magnitude }\left(\mathrm{M}_{\mathrm{S}}\right)\end{array}$ & $6.4^{1}$ & $6.2^{1}$ \\
\hline $\begin{array}{l}\text { Seismic moment } \\
\text { (Mo }\end{array}$ & $8 \times 10^{25}$ & $\begin{array}{l}4 \times 10^{25} \\
\text { dyne-cm }\end{array}$ \\
\hline
\end{tabular}

1 Values from Monthly Listings, Preliminary Determination of Epicenters, U.S. Geological Survey. 
following each earthquake (T. P. Miller, oral commun., July and September 1983). Few geologic or hydrologic effects were seen, in part because of the depth of the earthquakes. The July earthquake triggered a few small landslides, but none were observed after the September event. No surface faulting was observed for either shock. Both earthquakes caused slight damage in Valdez-primarily goods knocked off shelves-and were widely felt throughout Prince William Sound, on the Kenai Peninsula, and in the Susitna lowlands. No significant structural damage was reported for either event.

The July shock produced the strongest ground acceleration yet recorded for an Alaskan earthquake (Maley and Ellis, 1984). A strong-motion seismograph located at the Valdez High School recorded a peak horizontal acceleration of $0.32 \mathrm{~g}$ on the N-S component. In comparison, the peak acceleration recorded about $1 \mathrm{~km}$ away at the Valdez City Hall was $0.13 \mathrm{~g}$. The difference in the amplitude and character of shaking at the two sites is attributed to differences in the dynamic response of the surficial geologic materials at the two sites. Records from the September earthquake likewise showed stronger shaking at the high school; however, at both sites the accelerations from the September shock were smaller (less than $0.10 \mathrm{~g}$ ).

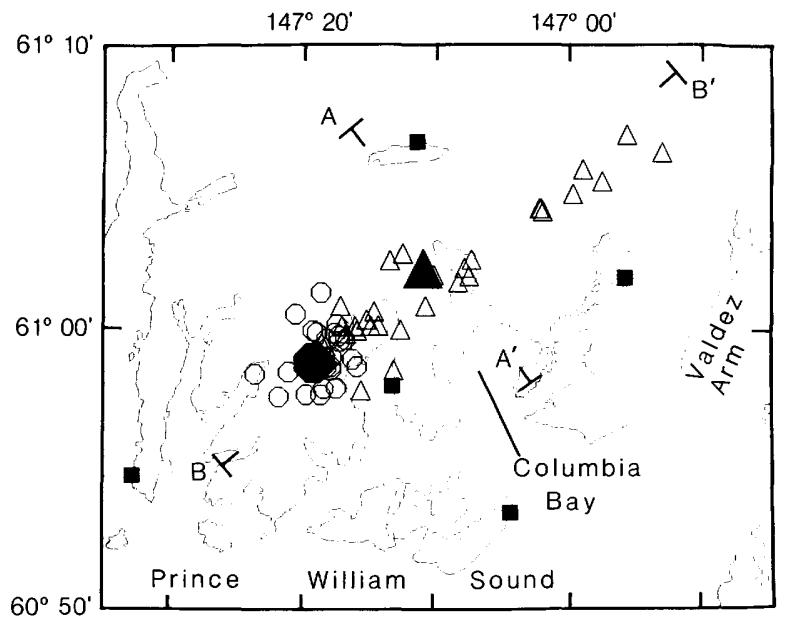

0

10 KILOMETERS

Figure 58.--Epicenters of Columbia Bay main shocks (large solid symbols) and well-located aftershocks. All aftershocks were recorded by local temporary seismographs (solid squares), as well as by more distant regional stations. Triangles, shocks from July 16-24; octagons, shocks from September 1214. Aftershock magnitudes, determined from the duration of signal codas at regional stations, range from 1.6 to 3.8. Westernmost seismograph operated in September only, others in both July and September. Letters indicate cross sections in figure 59 .

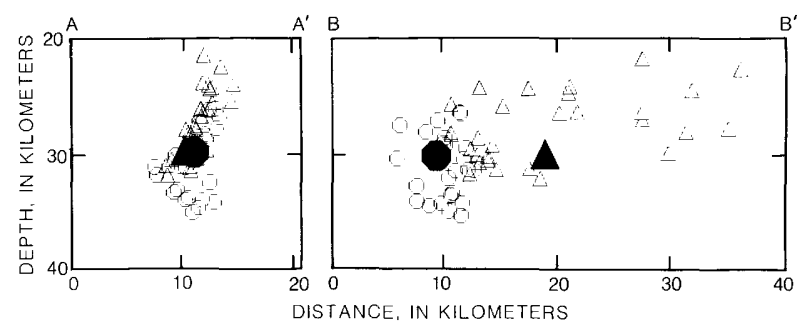

Figure 59.--Cross sections of Columbia Bay main shocks and well-located aftershocks. Data and symbols as in figure 58 . Section $\mathrm{AA}^{\prime}$, view to the northeast along strike; $\mathrm{BB}^{\prime}$, view to the northwest broadside to af tershock zone.

Both earthquakes triggered several strong-motion recorders in Anchorage, but none registered accelerations as large as $0.10 \mathrm{~g}$. The peak motions in Anchorage were nearly identical for the two shocks.

Both earthquakes were followed by numerous aftershocks that provided valuable information on the subsurface faulting. To obtain accurate aftershock locations, especially focal depths, 3 or 4 three-component seismographs were temporarily deployed after each earthquake in and around the epicentral region. The portable seismographs were deployed within 4 or 5 days of the main shocks. The July station sites were reoccupied in September. In addition to the portable seismographs, three nearby seismograph stations, which had been operated for several years as part of the Geological Survey's regional network until being deactivated in 1982 for lack of funding, were reactivated.

Aftershocks of the July earthquake define a steeply dipping planar fault striking at an azimuth of $55^{\circ}$, dipping $65^{\circ}$ to the northwest, and lying in the depth range $22-32 \mathrm{~km}$ (triangles, figs. 58, 59). The hypocenters are probably accurate to 2 or $3 \mathrm{~km}$. The length of the aftershock zone for the fourth day of the sequence through the twelf th day is $27 \mathrm{~km}$, at least $7 \mathrm{~km}$ longer than for the first day of the sequence, as determined from aftershocks recorded only by stations of the regional network. Thus, aftershock activity following the first day apparently extended the initial rupture several kilometers northeastward.

The September main shock occurred immediately southwest of the July aftershock zone (figs. 58, 59). The ensuing aftershocks were more numerous, but more localized, than those in July. The September hypocenters define a cluster about 6-9 $\mathrm{km}$ in diameter, lying in the depth range 26-35 $\mathrm{km}$ (octagons, figs. 58, 59). There is no indication that the September aftershock zone expanded between the first and seventh day of the sequence.

The smaller aftershock area for the September shock suggests a smaller rupture, a pattern that is consistent with the smaller long-period surfacewave magnitude and the smaller seismic moment 
reported for that event (table 18). The two aftershock zones appear to overlap slightly; however, the overlap could be an artifact arising from location errors. In any case, the September earthquake did not reactivate a substantial fraction of the July rupture zone.

The polarities of $\mathrm{P}$ waves recorded at regional and teleseismic distances indicate predominantly normal faulting and practically identical mechanisms for the July and September earthquakes. One of the P-wave nodal planes for each shock correlates closely with the rupture plane defined by the aftershocks (figs. 58, 59). In both cases, there is a component of left slip. The least compressive principal stress axes are subhorizontal, gently plunging to the northwest. Similar predominantly normal faulting at depths greater than $20 \mathrm{~km}$ was exhibited by two nearby magnitude 5 earthquakes that occurred in the Columbia Bay-Valdez Arm vicinity in August and September 1973.

Jacob and Perez (1981) suggested that earthquakes beneath Kodiak Island and offshore of the Kenai Peninsula with depths and focal mechanisms similar to those of the Columbia Bay shocks could be associated with bending stresses occurring in either the upper part of the subducting Pacific plate or in the lower part of the overriding North American plate near its leading edge. The plate interface beneath the northern Prince William Sound region is not clearly expressed in the 12 years of seismicity data available from the regional seismic network. However, projecting the depth distribution of earthquakes beneath upper Cook Inlet and northern Kenai Peninsula (Lahr and Stephens, 1983), we infer that beneath northern Prince William Sound, the plate interface is shallower than 20 or $30 \mathrm{~km}$. Thus, we surmise that the Columbia Bay earthquakes lie in the upper part of the subducting Pacific plate.

\section{REFERENCES CITED}

Lahr, J. C. and Stephens, C. D., 1983, Seismic activity in the vicinity of Anchorage, Alaska, 1972-82 (abs.): EOS (Transactions of the American Geophysical Union), v. 64, p. 89-90.

Jacob, K. H., and Perez, O. J., 1981, Crustal deformation and stress patterns resulting from the shallowly dipping subduction zone in the Gulf of Alaska (abs.): EOS (Transactions of the American Geophysical Union), v. 62, p. 398.

Maley, Richard and Ellis, Fred, 1984, Strong-motion records from the Columbia Bay, Alaska, earthquakes of July 12 and September 7, 1983: Earthquake Engineering Research Institute Newsletter, v. 18, no. 1, p. 30-32.

Reviewers: John Boatwright and G. S. Fuis

\section{KAYAK ISLAND- \\ ANALYSIS OF A GEOCHEMICAL ANOMALY}

\section{by William J. Pick thorn, Richard J. Goldfarb, Richard M. O'Leary, Stephen J. Sutley, and Sarah Weaver}

Kayak Island is in the northern Gulf of Alaska, near the abandoned town site of Katalla. Examination of samples collected during $1980-82$ as part of geochemical studies in the Chugach National Forest identified significant barium and zine anomalies on Kayak Island; these anomalies continue northeast on to the mainland, into and near the Don J. Miller Hills (Nelson and others, 1984). Soils were sampled during the summer of 1983 to further determine the nature of the anomalies and extent of economic potential, if any.

Highly anomalous values for barium and zinc (up to $9,000 \mathrm{ppm}$. Ba and $300 \mathrm{ppm} \mathrm{Zn}$ ) and minor associated copper, molybdenum, and lead values in stream-sediment samples, along with elevated values for dissolved sulf ate in stream water, suggest that Kayak Island has potential for previously unrecognized barite-sphalerite mineralization. Data from stream-sediment panned concentrates is even more suggestive, with $\mathrm{Ba}$ and $\mathrm{Zn}$ values ranging to more than $50,000 \mathrm{ppm}$. Visual examination showed that the concentrates contained abundant sphalerite, barite (some black), and pyrite (R. B. Tripp, U.S. Geological Survey, oral commun., 1983). Galena and chalcopyrite were also noted in several samples.

Bedrock on Kayak Island consists principally of the Eocene to Miocene Poul Creek and Miocene Yakataga Formations (Plafker, 1974; Rau and others, 1983). The Poul Creek Formation, which includes rocks formerly assigned to the Katalla Formation (Rau and others, 1983), is composed of sandstone and siltstone, with interbedded mafic pyroclastic rocks and flows in the upper part of the unit (Plafker, 1974). Abundant pyrite and glauconite are also found in the upper part of the Poul Creek Formation. The Yakataga Formation is made up predominantly of ice-rafted silt and sand, which is in part conglomeratic. Several small mafic dikes and sills cut the Poul Creek Formation (formerly Katalla Formation of Plafker, 1974), but are not found in the Yakataga Formation. These mafic intrusives closely resemble the flows in the upper part of the Poul Creek Formation and are interpreted by Plafker (1974) as feeders for the extrusive phases. A small dacite plug intrudes both the Yakataga and Katalla Formations and forms the southern tip of the island. Sedimentary rocks have been hornfelsed for several hundred feet adjacent to the intrusive (Plafker, 1974).

Due to extensive vegetative cover, soils were sampled to attempt to locate and identify the source of the sulfate and sulfide minerals. Using Plafker's (1974) geologic map of Kayak Island as a 
guide, sampling sites were selected over major structures (faults and folds) and the different rock units. Samples were collected from the $\mathrm{C}$ soil horizon using a 3-in.-diameter soil auger with extensions to dig through the tundra. Each sample was analyzed by atomic absorption for $\mathrm{Zn}, \mathrm{Ag}, \mathrm{Co}, \mathrm{Bi}$, As, and Se, and by semi-quantitative spectrographic analysis for the standard 32 elements. The samples were then leached with oxalic acid and reanalyzed for barium and zine to determine the association of these elements with manganese and iron oxides (Chao and Theobald, 1976). Zine is very mobile in the weathering environment and will precipitate with manganese and iron as oxides. High $\mathrm{Zn}$ values in the soils and in the oxalic acid leach may represent "false" anomalies, whereas high soil values with low oxalic acid leach values most likely reflect primary minerals in the bedrock.

The high barium values show a strong correlation with the glauconitic horizons in the upper Poul Creek Formation on Kayak Island. Zinc, which is very mobile, shows a fairly random distribution in the soil, occuring in varying amounts over both the Yakataga and Poul Creek Formations. By using the oxalic acid leach data to aid in determining "false" anomalies in the soil data, the "true" zinc anomalies were shown to be associated with the mafic flows and dikes in the upper part of the Poul Creek Formation.

The streams on Kayak Island have very steep drainages that tend to concentrate the heavier minerals while carrying away the lighter material, creating biased or false anomalies. Although the high barium and zinc values in the stream sediments and concentrates seem promising, they do not appear to indicate potential for economic barite-sphalerite mineral deposits on Kayak Island.

\section{REFERENCES CITED}

Chao, T. T., and Theobald, P. K., Jr., 1976, The significance of secondary iron and manganese oxides in geochemical exploration: Economic Geology, v. 71, p. 1560-1569.

Nelson, S. W., Miller, M. L., Barnes, D. F., Dumoulin, J. A., Goldfarb, R. J., Koski, R. A., Mull, C. G., Pickthorn, W. J., Jansons, U., Hoekzema, R. B., Kurtak, J. M., and Fechner, S. A., 1984, Mineral resource potential of the Chugach National Forest, AlaskaSummary report: U.S. Geological Survey Miscellaneous Field Studies Map and Report, MF-1645-A, 24 p., 1 sheet, scale 1:250,000.

Plafker, George, 1974, Preliminary geologic map of Kayak and Wingham Islands, Alaska: U.S. Geological Survey Open-File Map 74-82, 1 sheet, scale $1: 31,680$.

Rau, W. W., Plafker, George, and Winkler, G. R., 1983, Foraminiferal biostratigraphy and correlations in the Gulf of Alaska Tertiary
Province: U.S. Geological Survey Oil and Gas Investigations Chart OC-120.

Reviewers: George Plafker and M. F. Diggles

\section{SEISMICITY IN SOUTHERN ALASKA, OCTOBER 1982 - SEPTEMBER 1983}

\section{by Christopher D. Stephens, Kent A. Fogleman, Robert A. Page, and John C. Lahr}

Several notable earthquakes occurred in or near southern Alaska between October 1982 and September 1983 (fig. 60; table 19). These include: two magnitude* 6 shocks in July and September 1983 located beneath Columbia Bay along the northern margin of Prince William Sound, which are the largest events to occur in this area since the 1964 Alaska earthquake; a magnitude 6 shock in June 1983 located north of Icy Bay, which is the largest event in the aftershock zone of the $1979 \mathrm{St}$. Elias earthquake $\left(7.1 \mathrm{M}_{\mathrm{S}}\right)$ since the mainshock; and several magnitude 5 shocks, including a $5.3 \mathrm{~m}_{\mathrm{b}}$ shock in January 1983 north of the Columbia Bay shocks, a $5.4 \mathrm{~m}_{\mathrm{b}}$ event in March 1983 on the Duke River fault in Yukon Territory north of Yakutat Bay, and a $5.0 \mathrm{~m}_{\mathrm{b}}$ shock in August 1983 southeast of Montague Island. Four other magnitude 5 shocks occurred during this time period, one in the St. Elias aftershock zone, one in the Columbia Bay aftershock zone, and two in the Aleutian Benioff zone west and north of Cook Inlet.

Aside from aftershock activity related to some of these larger events, the distribution and rate of smaller events throughout the network (fig. 61) were similar to those observed over the past several years (for example, Stephens and others, 1984). West of Prince William Sound, the distribution of seismicity is dominated by activity in the northwestward-dipping Aleutian Benioff zone, with relatively minor activity occurring in the crust of the overriding North American plate. An apparent concentration of shallow activity along the volcanic arc west of Cook Inlet is at least partially due to recent emphasis placed on locating events around the volcanoes. East of Prince William Sound, a lower magnitude threshold is used to select events for processing because the rate of activity is lower than to the west. The distribution of this seismicity is less uniform and concentrated at shallower depths than in the western part of the network. Principal features in the seismicity are: (1) pronounced activity in the St. Elias aftershock zone north and east

\footnotetext{
* Surface-wave $\left(\mathrm{M}_{\mathrm{s}}\right)$ and body-wave $\left(\mathrm{m}_{\mathrm{b}}\right)$ Determination of Epicenters (PDE) of the U. S. Geological Survey National Earthquake Information Service (NEIS).
} 


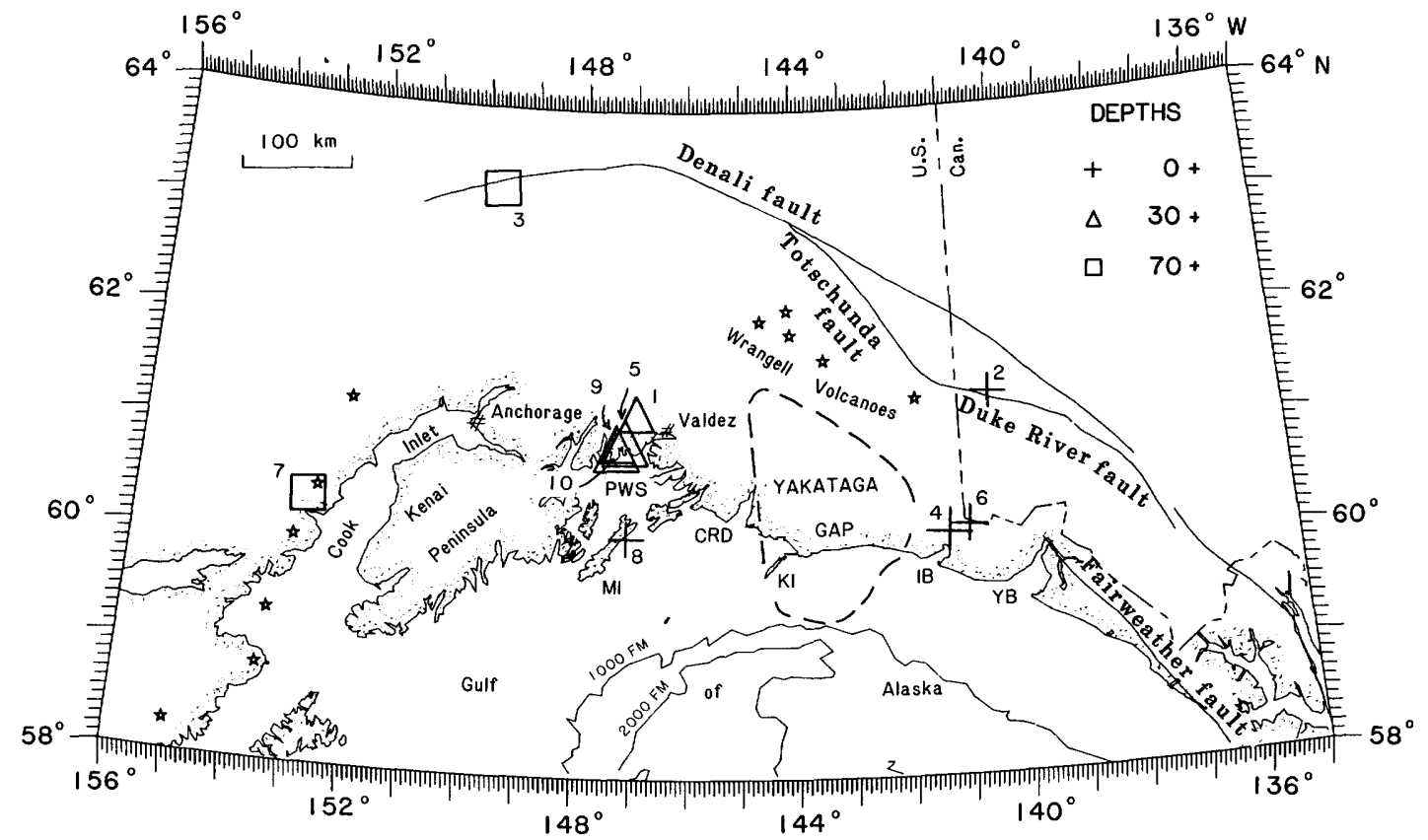

Figure 60.-Earthquakes of magnitude $5 \mathrm{~m}_{\mathrm{b}}$ and larger that occurred in southern Alaska, Oct 1982-Sept 1983. Larger symbol size corresponds to magnitude 6 and larger. Numbers next to events correspond to those listed in table 19. Dashed outline indicates approximate extent of Yakataga gap. CRD, Copper River Delta; IB, Icy Bay; KI, Kayak Island; MI, Montague Island; PWS, Prince William Sound; YB, Yakutat Bay. Stars indicate Quaternary volcanoes.

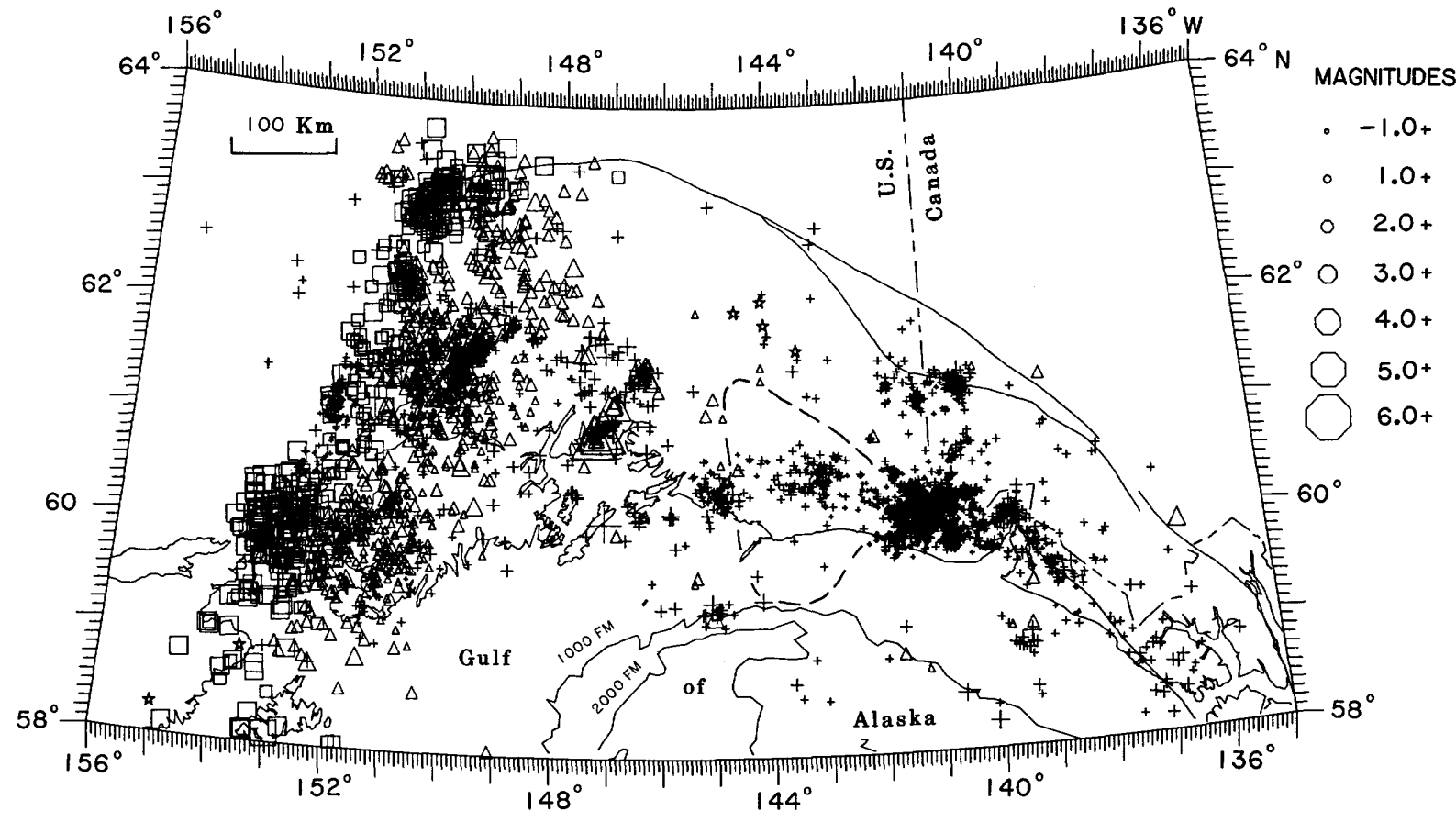

Figure 61.--Seismicity in southern Alaska, Oct 1, 1982-Sept 30, 1983. Epicenters for 4,567 events are plotted. Symbol type corresponds to depth as indicated in figure 60 . Magnitudes are determined from coda-duration. The lowest magnitude level to which data is processed varies within the mapped area due to uneven station distribution and to criteria used to select earthquakes for processing (see text). 
Table 19. Magnitude $5 \mathrm{M}_{\mathrm{b}}$ and larger earthquakes in southern Alaska, October 1982 - September 1983

\begin{tabular}{lcclcrll}
\hline No. & $\begin{array}{c}\text { Date } \\
\text { yr/mo/day }\end{array}$ & $\begin{array}{c}\text { Time } \\
\text { UT }\end{array}$ & $\begin{array}{c}\text { Latitude } \\
\text { (north) }\end{array}$ & $\begin{array}{c}\text { Longitude } \\
\text { (west) }\end{array}$ & $\begin{array}{c}\text { Depth } \\
(\mathrm{km})\end{array}$ & $\begin{array}{c}\text { Mag. } \\
\left(\mathrm{m}_{\mathrm{b}}\right)\end{array}$ & Region \\
\hline 1 & 830101 & $11: 18$ & $61^{\circ} 17^{\prime}$ & $146^{\circ} 57^{\prime}$ & 37 & 5.3 & North of Columbia Bay \\
2 & 830330 & $18: 06$ & $61^{\circ} 24^{\prime}$ & $140^{\circ} 23^{\prime}$ & 2 & 5,4 & Duke River fault \\
3 & 830419 & $19: 12$ & $63^{\circ} 16^{\prime}$ & $149^{\circ} 42^{\prime}$ & 121 & 5.1 & Aleutian Benioff zone \\
4 & 830628 & $03: 25$ & $60^{\circ} 10^{\prime}$ & $141^{\circ} 15^{\prime}$ & 15 & 6.0 & St. Elias \\
5 & 830712 & $15: 10$ & $61^{\circ} 02^{\prime}$ & $147^{\circ} 11^{\prime}$ & 30 & 6.1 & Columbia Bay \\
6 & 830715 & $07: 49$ & $60^{\circ} 14^{\prime}$ & $140^{\circ} 53^{\prime}$ & 14 & 5.1 & St. Elias \\
7 & 830806 & $16: 34$ & $60^{\circ} 24^{\prime}$ & $152^{\circ} 54^{\prime}$ & 129 & 5.4 & Aleutian Benioff zone \\
8 & 830809 & $15: 58$ & $60^{\circ} 10^{\prime}$ & $147^{\circ} 06^{\prime}$ & $15^{\mathrm{c}}$ & 5.0 & Montague Island \\
9 & 830907 & $19: 22$ & $60^{\circ} 59^{\prime}$ & $147^{\circ} 19^{\prime}$ & 30 & 6.2 & Columbia Bay \\
10 & 830907 & $22: 22$ & $61^{\circ} 00^{\prime}$ & $147^{\circ} 18^{\prime}$ & 30 & 5.0 & Columbia Bay \\
& & & & & & &
\end{tabular}

\section{Depth constrained}

of Icy Bay; (2) concentrations of activity beneath the Copper River Delta and in the Yakataga gap area beneath Waxell Ridge about $75 \mathrm{~km}$ northeast of Kayak Island; (3) scattered activity across the continental shelf, with moderate-sized events tending to occur along the edge of the continental shelf; (4) diffuse activity along the Fairweather fault system north and east of Yakutat Bay and along the Denali fault system; and (5) a few events that occurred in the northeastward-dipping Wrangell Benioff zone south of the Wrangell volcanoes.

Focal mechanisms for the two Columbia Bay shocks determined from regional and teleseismic Pwave first motions and from the distribution of aftershocks (Page and others, this volume) indicate normal faulting on a steeply northwest-dipping plane between depths of about 20 and $35 \mathrm{~km}$. The fault is inferred to occur in the upper part of the subducted Pacific plate. In January 1983, a magnitude $5.3 \mathrm{~m}$ shock occurred about $30 \mathrm{~km}$ north of the July shock at a depth of about $37 \mathrm{~km}$. The mechanism for this event, determined from $\mathrm{P}$-wave first motions at regional stations and a few teleseismic stations, also indicates normal faulting with northeast-striking nodal planes, although the orientation of the nodal planes is less certain than for the July and September shocks. The January shock occurred near the southern end of a northeasttrending zone of activity that has persisted since at least 1971 when the network was established. The Columbia Bay aftershock zone is offset from and rotated clockwise with respect to this northerly zone (fig. 61), suggesting that the activity in these two zones probably occurs on different structures.

The $m_{b} 6.0$ shock north of Icy Bay was located near the center of the aftershock zone of the St. Elias earthquake at a depth of about $15 \mathrm{~km}$. The focal mechanism determined from regional $\mathrm{P}$-wave first motions is compatible with predominantly lowangle thrusting on a northward-dipping plane and is consistent with the teleseismic solution published by
NEIS. The mechanism is similar to the low-angle thrusting inferred for the St. Elias mainshock (Hasegawa and others, 1980) and several larger aftershocks (Stephens and others, 1980; Stephens and others, 1984). The June 1983 event occurred near the southwest edge of a zone characterized by a relatively high rate of continuous aftershock activity since the St. Elias mainshock. This event and other shocks of magnitude 5 and larger that have occurred nearby in the zone generally have not triggered strong secondary aftershock activity; only 43 shocks of coda-duration magnitude 1 and larger occurred within 3 days and $10 \mathrm{~km}$ of the June 1983 shock. Similarly, a magnitude 5 shock in July 1983 occurred about $20 \mathrm{~km}$ east of the June event in the zone of high activity; it was without a strong secondary aftershock sequence. In contrast, 324 shocks of magnitude 1 and larger occurred within 3 days of a magnitude 5.0 shock in May 1982 that was located about $20 \mathrm{~km}$ south of the June 1983 event in the St. Elias aftershock zone (Stephens and others, 1984).

A preliminary focal mechanism determined by NEIS from teleseismic data for the March 1983 event on the Duke River fault indicates predominantly thrust faulting on southeast-striking nodal planes. The locations of the aftershocks from this event are not sufficiently well constrained to determine a fault plane, but a southward-dipping fault plane would be compatible with the mapped attitude of the fault at the surface.

Between January and September 1983, eight shocks of magnitude 5 and larger occurred within about $200 \mathrm{~km}$ of the $150-\mathrm{km}$-wide Yakataga seismic gap, which extends between the rupture zones of the 1964 and 1979 earthquakes approximately from the longitudes of Kayak Island to Icy Bay (fig. 60). This represents the highest annual rate of events at this magnitude level since 1970-71, although no corresponding change in the rate of microearthquake activity in the gap was noted for the recent time period. Only the two shocks closest to the gap, 
those in the the St. Elias aftershock zone, are thought to have occurred on the northerly dipping interplate thrust that is inferred to extend beneath the region and is expected to rupture in a gap-filling event. The other shocks were located more than $100 \mathrm{~km}$ from the perimeter of the gap, and it is unlikely that any of these events significantly affected the stress conditions in the gap. However, it is possible that the increased rate of larger events reflects a change in regional stress conditions that could affect the likelihood of a large event occuring in the gap.

\section{REFERENCES CITED}

Hasegawa, H. S., Lahr, J. C., and Stephens, C. D., 1980, Fault parameters of the St. Elias, Alaska, earthquake of February 28, 1979: Bulletin of the Seismological Society of America, v. 70, p. 1651-1660.

Stephens, C. D., Lahr, J. C., Fogleman, K. A., and Horner, R. A., 1980, The St. Elias, Alaska earthquake of February 28, 1979-Regional recording of aftershocks and short-term, preearthquake seismicity: Bulletin of the Seismological Society of America, v. 70, p. 1607-1633.

Stephens, C. D., Lahr, J. C., and Page, R. A., 1984, Seismicity along southern coastal Alaska: October 1981 - September 1982, in Reed, K. M. and Bartsch-Winkler, Susan, eds., The United States Geological Survey in AlaskaAccomplishments during 1982: U. S. Geological Survey Circular 939, p. 78-82.

Reviewers: F. W. Klein and J. I. Ziony

\section{SOUTHEASTERN ALASKA}

\section{(Figure 62 shows study areas deseribed.)}

\section{RE-INTER PRETATION OF THE AGE OF THE KUIU-ETOLIN BELT VOLCANIC ROCKS, KUPREANOF ISLAND, SOUTHEASTERN ALASKA}

\section{by David A. Brew, Susan $M_{1}$ Karl, and Eugene F. Tobey}

The Kuiu-Etolin volcanic-plutonic belt (Brew and others, 1979) consists of a variety of volcanic and plutonic rocks in a belt extending northwestsoutheast across the Petersburg map area (fig. 62). Its geologic features are mapped and described by Brew and others (1984). The part of the belt discussed here corresponds to the south end of the Tertiary Admiralty trough of Miller and others (1959). The purpose of this note is to re-interpret the age of the volcanic rocks of the belt. These rocks are not formally named.

\footnotetext{
${ }^{1}$ Bushwalker Exploration, Eagle River, AK 99577
}

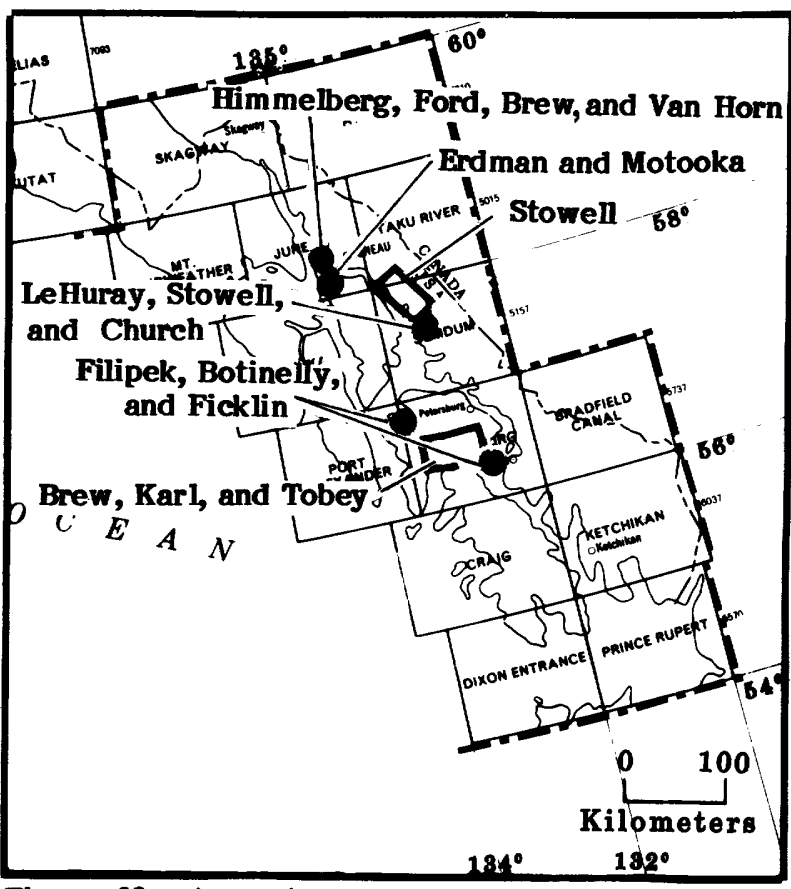

Figure 62.--Areas in southeastern Alaska discussed in this circular. Outlines define the areas described by the indicated authors.

Buddington and Chapin (1929) provided the first thorough description of the volcanic rocks in the belt, based on Buddington's observations in the southern Kupreanof and east-central Kuiu Islands area. Buddington recognized that some of the rocks, especially those on southeastern Kupreanof Island, appeared to be appreciably younger than others. Nevertheless, he concluded that they were all of Tertiary age, based on the fact that they overlie plant-bearing sediments of early Tertiary age. Miller and others (1959) used Buddington and Chapin's information in their analysis of the Tertiary Admiralty trough. Loney (1964) and Lathram and others (1965) contributed additional age information on the apparently time-equivalent volcanic and sedimentary rocks on Admiralty Island; these rocks are named the Admiralty Island Volcanics and Kootznahoo Formation (Lathram and others, 1965). The Kootznahoo Formation on Admiralty Island is now considered to be of Eocene to Miocene age, on the basis of plant fossils in sandstone beds (Wolfe, 1966; Wolfe, written commun., 1979; 1983). The Admiralty Island Volcanics generally overlie the Kootznahoo Formation, but intertongue near their base. In 1971, three whole-rock samples collected by H.C. Berg from basalt flows on Level Island, close to southeastern Kupreanof Island, were dated by M.A. Lanphere using the $\mathrm{K}-\mathrm{Ar}$ method. The results suggested that the rocks sampled were no more than a few hundred thousand years old (M.A. Lanphere, U.S. Geological Survey, written commun., 1972). 


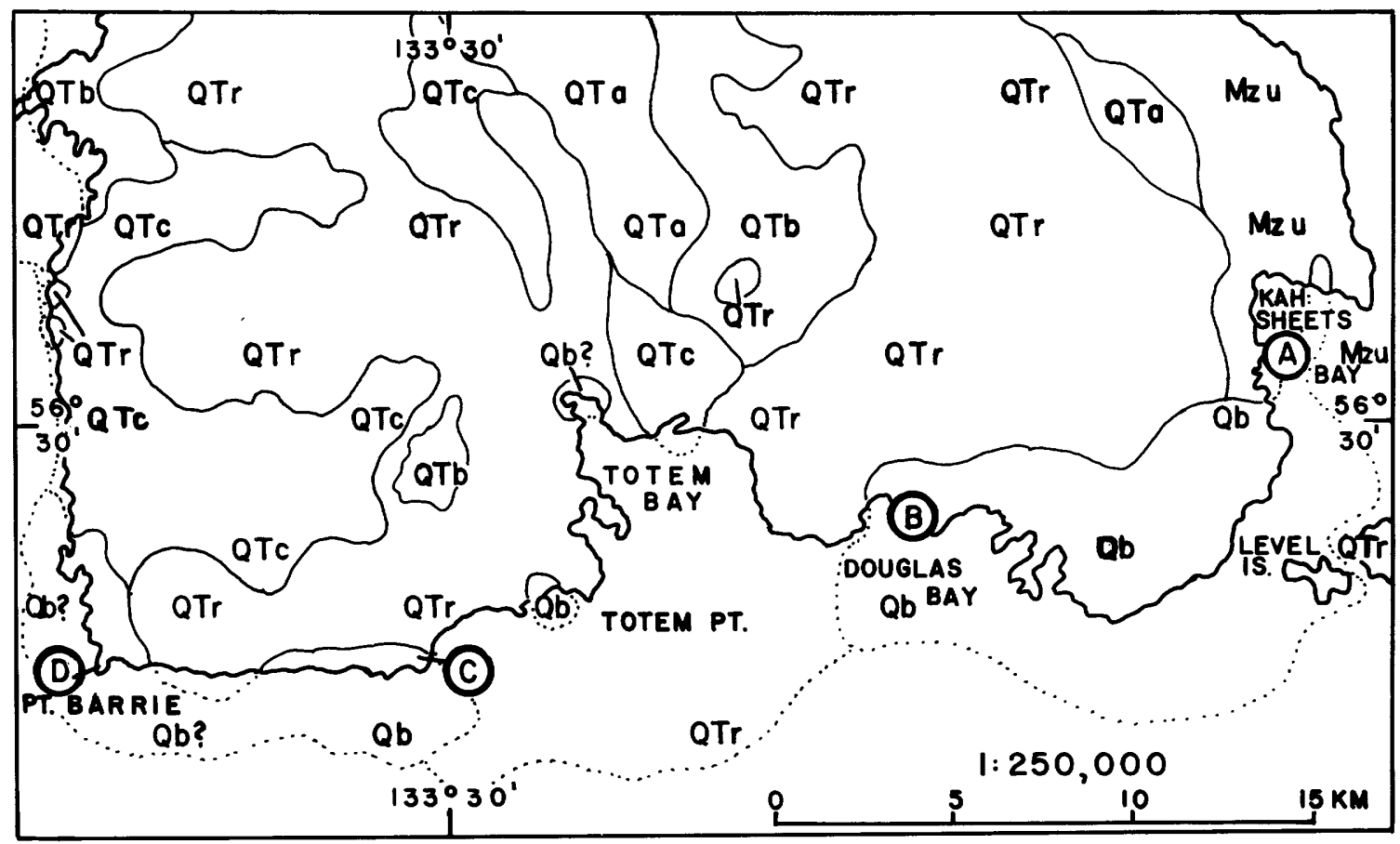

Figure 63.--Geologic map of southern Kupreanof Island (from Brew and others, 1984) showing localities $A$ through $D$ referred to in the text and map units as follows : $Q b$, Quaternary extrusive basaltic rocks and underlying sediments; QTr, Quaternary(?) and Tertiary rhyolite, rhyodacite, and related siliceous extrusive and intrusive rocks; QTc, Quaternary(?) and Tertiary volcaniclastic deposits; QTa, Quaternary(?) and Tertiary andesite and other intermediate extrusive rocks; QTb, Quaternary(?) and Tertiary basalt and other mafic extrusive rocks; and $\mathrm{Mzu}$, Mesozoic rocks underlying the volcanic rock units.

During fieldwork in 1983 , Tobey recognized a glacial till unit interbedded with volcanic flows in a quarry on a small peninsula in Kah Sheets Bay on southeastern Kupreanof Island (A, fig. 63) and informed the other authors. Additional fieldwork did not identify any other till occurrences, but it did lead to: (1) recognition of extensive Quaternary flows and associated locally underlying sandstones and conglomerates; (2) inference of a Tertiary and Quaternary(?) age for the remainder of the volcanic rocks on southwestern Kupreanof Island; and (3), reconsideration of the plutonic and volcanic history of the Kuiu-Etolin belt.

The youngest unit in the volcanic pile (represented by the symbol $\mathrm{Qb}$, fig. 63), which is interpreted to be Holocene and(or) Pleistocene, consists of several tens of meters of extrusive basaltic rocks and associated underlying sediments that locally overlie the till in places. The till has been recognized at only one locality, and no striated pavements have been seen. No glacial deposits have been recognized overlying these flows.

In this unit, fresh, locally polygonally jointed, dark greenish-gray, dense, very fine-grained to aphanitic, magnetite-bearing olivine basalt and minor pyroxene basalt are the most common rock types. Most flows are less than $1 \mathrm{~m}$ thick, but some individual flows are up to $10 \mathrm{~m}$ thick; all are typically columnar jointed. Well developed pahoehoe flows with tumuli are common. The flows are underlain locally by dark gray aa flows and mafic volcanic breccia in layers up to $0.5 \mathrm{~m}$ thick and by locally derived, poorly sorted, well-bedded brownto gray-weathering polymictic, volcanic-clast-rich conglomerate, pebbly sandstone, sandstone, and minor siltstone, deposited in fluvial or beach environments. The locality in Kah Sheets Bay exposes well-indurated, matrix-supported polymictic glacial till in a 1-m-thick and 3-m-long lens underlying dense aphanitic basalt. The till is medium to light gray and consists of very poorly sorted, rounded to angular, fine to coarse gravel-size clasts of schist, graywacke, greenstone, and carbonate "floating" in a dense, microscopically layered matrix of calcite and clay. The K-Ar-dated samples mentioned previously are from the dense aphanitic basalt unit.

The flows of the youngest unit ( $\mathrm{Qb}$ of fig. 63) and the underlying sediments of unit $\mathrm{Qb}$ are best exposed along the south shore of Kupreanof Island from Kah Sheets Bay (A, fig. 63) to Douglas Bay (B, fig. 63), just west of Totem Bay, and at Indian Point and on High Castle Island in Duncan Canal. From 
beyond locality $\mathrm{C}$ to north of Point Barrie (D, fig. 63 ), we cannot conclusively identify map unit, but the complicated intrusive and extrusive volcanic pile in this area may include rocks belonging to it.

Time-stratigraphic and lithostratigraphic relations are uncertain in the rocks inferred to underlie the youngest volcanic unit. Rhyolites and basalts appear to have erupted at as-yet undetermined times and in no obvious or simple sequence after the Paleocene (as indicated by the age of the Kootznahoo Formation here where it locally underlies the volcanic pile). The four main units in this pile are as follows (fig. 63):

(1) Rhyolite, rhyodacite, and related siliceous extrusive and intrusive rocks (represented by the symbol QTr in fig. 63), which may be several hundreds of meters thick, consist of aphanitic to finely crystalline, generally quartz- and feldspar-porphyritic rocks that are locally layered, spherulitic, and(or) miarolitic. Heterogeneous stratigraphy includes lava flows, obsidian flows, lahars, welded and nonwelded ash, tuff, and lapilli, all cut locally by porphyritic rhyolite and rhyodacite dikes. Extreme alteration, brecciation, and diking identify vents and domes. Massive, structureless, isolated rhyolite bodies suggest plugs. Columnarjointed flows exposed in cliffs greater than $100 \mathrm{~m}$ high are interpreted as cooling units.

(2) Andesite and other intermediate extrusive rocks (represented by the symbol QTa in fig. 63) consist of at least several tens of meters of fresh dark gray or altered green to maroon, blocky weathering, pyroxene and feldspar porphyritic, massive to vesicular and amygdaloidal flows which are $10-50 \mathrm{~cm}$ thick.

(3) Basalt and other mafic extrusive rocks (QTb) consist of at least several tens of meters of dark-gray, rusty weathering, platy, blocky, or columnar jointed flows from $50 \mathrm{~cm}$ to several $\mathrm{m}$ thick. The flows are commonly vesicular and amygdaloidal; amygdule fillings include calcite, epidote, chalcedony, chlorite, and zeolites, in order of decreasing abundance. Platy flows are pyroxene microporphyritic; massive flows may contain magnetite, pyroxene, and olivine.

(4) Volcaniclastic deposits (represented by the symbol QTe in fig. 63) consist of an unknown thickness of unsorted to sorted pyroclastic deposits, including felsic to mafic tuff, lapilli tuff, tuff breccia, felsic to mafic lahars, and oligomictic conglomerate. These rocks tend to occur in and around outcrops of, and are locally intercalated with, the rhyolite, rhyodacite, and related extrusive and intrusive rock unit.
According to this re-interpretation, at least a small part of the volcanic sequence in the KuiuEtolin volcanic-plutonic belt definitely post-dates the youngest recognized glacial activity; it is possible that a much larger part of the sequence is Holocene and(or) Pleistocene. The young flows both conceal and probably have less mineral resource potential than the underlying Tertiary volcanic rocks. Further definition of their relation to the older volcanic rock units may be important in future mineral resource exploration in this part of the Kuiu-Etolin belt.

\section{REFERENCES CITED}

Brew, D. A., Berg, H. C., Morrell, R. P., Sonnevil, R. S., and Hunt, S. J., 1979, The mid-Tertiary Kuiu-Etolin volcanic-plutonic belt, southeastern Alaska, in Johnson, K. M., and Williams, J. R., eds., The United States Geological Survey in Alaska--Accomplishments during 1978: U.S. Geological Survey Circular 804-B, p. B129B130.

Brew, D. A., Ovenshine, A. T., Karl, S. M., and Hunt, S. J., 1984, Preliminary reconnaissance geologic map of the Petersburg and parts of the Port Alexander and Sumdum 1:250,000 Quadrangles, southeastern Alaska: U.S. Geological Survey Open-File Report 84-405, 2 sheets, 43 p. pamphlet.

Buddington, A. F., and Chapin, Theodore, 1929, Geology and mineral deposits of southeastern Alaska: U.S. Geological Survey Bulletin 800, $398 \mathrm{p}$.

Lathram, E. H., Pomeroy, J. S., Berg, H. C., and Loney, R. A., 1965, Reconnaissance geology of Admiralty Island, Alaska: U.S. Geological Survey Bulletin 1181-R, $48 \mathrm{p}$.

Loney, R. A., 1964, Stratigraphy and petrography of the Pybus-Gambier area, Admiralty Island, Alaska: U.S. Geological Survey Bulletin 1178, $103 \mathrm{p}$.

Miller, D. J., Payne, T. G., and Gryc, George, 1959, Geology of possible petroleum provinces in Alaska: U.S. Geological Survey Bulletin 1094, $131 \mathrm{p}$.

Wolfe, J. A., 1966, Tertiary plants from the Cook Inlet Region, Alaska: U.S. Geological Survey Professional Paper 398B, p. B1-B32.

Reviewers: George Plafker and J. R. Williams.

\section{BIOGEOCHEMICAL RESPONSE AT THE GREENS CREEK MASSIVE SULFIDE DEPOSIT, ADMIRALTY ISLAND}

\section{by James A. Erdman and Jerry M. Motooka}

The use of vegetation as a guide to mineralization assumes that plants assimilate, to varying degrees, elements found in mineral deposits. The 

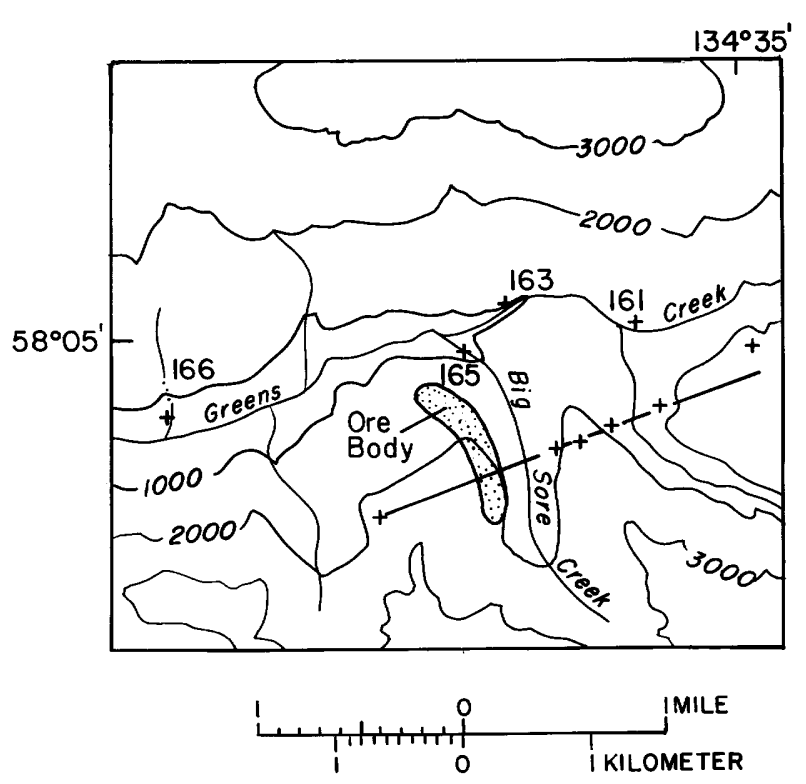

Contour interval 1000 feet

Figure 64.--Topographic map of the Big Sore deposit area in the Greens Creek watershed. Sitka spruce samples were taken at sites indicated along the traverse line and at drill-hole locations over the ore body. Aquatic mosses were collected at numbered sites along Greens Creek. Base from U.S. Geological Survey Juneau (A-2), Alaska, 15-minute topographic map, 1951.

analysis of the ash of plant samples may serve to locate such deposits. Few studies have been published on this use of plants in Alaska. One notable exception is a study of a uranium deposit in southeastern Alaska (Eakins, 1970), which included a study of Sitka spruce.

A pilot study primarily of Sitka spruce (Picea sitchensis) but also aquatic mosses was conducted in August 1983 at Noranda's Big Sore deposit in the Greens Creek watershed of Admiralty Island (fig. 64 ), about $29 \mathrm{~km}$ southwest of Juneau.

The study had two purposes: to determine (1) if biogeochemical techniques may be useful in southeastern Alaska, where much of the landscape is heavily vegetated, and (2) if sampling from a helicopter at tree-top level is not only feasible, but also useful. Tree-top sampling of cones by such means has been used routinely by the Canadian Forest Service. Geochemical sampling by fixed-wing aircraft was described a decade ago (Sainsbury and others, 1973), but sampling by helicopter for mineral exploration has not been reported. It has great potential in coastal Alaska where the steepness of the terrain, inaccessibility of outcrops, and the density of the forest hampers more conventional ground-level sampling.

The ore body is part of a structurally complex, discontinuous belt of volcanogenic massive sulfide deposits of probable Late Triassic age (H. C. Berg, U.S. Geological Survey, oral commun., July, 1983; Berg and Grybeck, 1980). According to J. S. Dreschler (Noranda Exploration, Inc., oral commun., July, 1983), the first drill hole penetrated about 27 $\mathrm{m}(90 \mathrm{ft}$ ) of massive sulfide ore rich in $\mathrm{Zn}, \mathrm{Pb}, \mathrm{Cu}$, and $\mathrm{Ag}$, with barite as a gangue mineral. Good pathfinder elements are $\mathrm{As}, \mathrm{Cd}, \mathrm{Hg}$, and $\mathrm{Sb}$. $\mathrm{De}-$ velopment of the deposit is still in the initial stages.

Sitka spruce was sampled because (1) it is a dominant forest tree in the coastal forest of southeastern Alaska (Harris and Farr, 1974, p. 16-17) and is easily recognized above the canopy; (2) it seems to have a greater affinity for the deeper mineral soil than does western hemlock, the other dominant tree (T. A. Hanely, Forestry Sciences Laboratory, Juneau, oral commun., July 1983); and (3) it tends to occur more frequently on well-drained sites than does hemlock (S. Torretta, Forestry Sciences Laboratory, oral commun., July 1983) and, therefore, may be more widespread.

A single branch was clipped from the top of a tree at each of 17 drill-hole sites either at or near the ore body. Many of the drill-hole sites corresponded to areas where soil anomalies for $\mathrm{Cu}, \mathrm{Pb}$, $\mathrm{Zn}$, and $\mathrm{Ag}$ were determined in an earlier survey (Noranda Exploration, Inc., unpub. data). Six sites were also sampled along a traverse normal to the strike of the steeply dipping major bedrock units (fig. 64). Sampling was done from an open helicopter with the person collecting the samples secured in a climbing harness.

Cones and stems of Sitka spruce were dried, ashed at $500^{\circ} \mathrm{C}$, leached with nitric acid, and analyzed separately by inductively coupled plasmaatomic emission spectrometry (ICP); needles of the plants were discarded. Contrast, for the most part, was low, and the results showed no consistent pattern related to mineralized outcrop or to soil anomalies. A puzzling negative "anomaly" occurred at the gossan. There, the lowest $\mathrm{Ba}, \mathrm{Al}$, and $\mathrm{Ni}$ concentrations were found in the cones, and the lowest As, B, Al, Ni, and $\mathrm{P}$ concentrations were found in the stems. Stems contained greater amounts of Be, $\mathrm{Co}, \mathrm{Cr}, \mathrm{Pb}$, and $\mathrm{Y}$ than did the cones; $\mathrm{Pb}$ was not detected in the cones. Elements showing a greater variation in concentration, making them more use$\mathrm{ful}$ as diagnostic indicators, were $\mathrm{As}, \mathrm{Ba}, \mathrm{Cd}, \mathrm{Mo}$, $\mathrm{Ni}$, and $\mathrm{Pb}$ (for stem samples). Maximum variation in these elements is at least an order of magnitude, differing markedly from the contrasts of no more than a factor of two for $\mathrm{Cu}$ and $\mathrm{Zn}$.

During the time that the spruce trees were being sampled, a ground party conducted a streamsediment and water sampling survey along Greens Creek. Samples of aquatic mosses were collected at several sites (fig. 64).

Mosses have been reported to act as passive ion exchangers and have a high surface-to-volume ratio; they are therefore effective traps for dissolved metals (Erdman and Modreski, 1984). Aqua- 
tic mosses are also effective sediment traps (Smith, 1976) and can retain much contaminant material, even after careful rinsing.

Ash yields of some of the aquatic moss samples (table 20) indicate high sediment loads, which complicate the interpretation of the analyses. However, when the results are expressed as concentrations in the dry material, the map pattern of the elements can be related to known mineral occurrences.

Of the analytical results shown in table 20, the only detectible As was found in the sample taken at the mouth of Big Sore Creek below the ore body. Concentrations (dry-weight basis) of $\mathrm{Ba}, \mathrm{Pb}$, $\mathrm{Zn}$, and $\mathrm{Cd}$ are anomalous in this sample when compared to both the regional background sample and the two samples collected in Greens Creek upstream from Big Sore Creek. The only $\mathrm{Cu}$ "anomaly" (twice background) occurred in sample JA166M (fig. 64). This moss sample also yielded levels of $\mathrm{Ba}, \mathrm{Cd}, \mathrm{Pb}$, and $\mathrm{Zn}$ comparable to those at the Big Sore Creek site.

In conclusion, results of the helicopterassisted sampling proved inconclusive. Tree-top sampling is clearly an efficient method, but, at least for Sitka spruce, it may not be a very useful one. On the other hand, it seems that aquatic mosses sampled from the watershed not only reflect the Big Sore deposit, but may point to another mineral occurrence more than a mile to the northwest.

\section{Ack now l edgemen $t s$}

We thank J. S. Dreschler of Noranda Exploration, Inc., for providing encouragement and data to aid in the study. T. Light, L. Filipek, J. Gray, and D. Huston collected the moss samples.

\section{REFERENCES CITED}

Berg, H. C., and Grybeck, D., 1980, Upper Triassic volcanogenic $\mathrm{Zn}-\mathrm{Pb}-\mathrm{Ag}(-\mathrm{Cu}-\mathrm{Au})$-barite mineral deposits near Petersburg, Alaska: U.S. Geological Survey Open-File Report 80-527, $7 \mathrm{p}$.

Eakins, G. R., 1970, An experiment in geobotanical prospecting for uranium, Bokan Mountain area, southeastern Alaska: Alaskan Division of Mines and Geology, Geological Report No. 41,52 p.

Erdman, J. A., and Modreski, P. J., 1984, Copper and cobalt in aquatic mosses and stream sediments from the Idaho Cobalt Belt: Journal of Geochemical Exploration, v. 20, p. 75-84.

Harris, A. S., and Farr, W. A., 1974, The forest ecosystem of southeast Alaska-7. Forest ecology and timber management: U.S. Department of Agriculture, Forest Service Technical Report PNW-25, 109 p.

Table 20.--Element concentrations (ppm in dry matter) of aquatic mosses from the Greens Creek watershed, Admi ralty Island. Concentrations in the ash appear in parentheses. See figure 64 for sample locations.

\begin{tabular}{lccccccc}
\hline Sample $^{\mathrm{a}}$ & $\begin{array}{c}\text { Ash } \\
\text { (percent) }\end{array}$ & \multicolumn{1}{c}{ As } & $\mathrm{Ba}$ & $\mathrm{Cd}$ & $\mathrm{Cu}$ & $\mathrm{Pb}$ & $\mathrm{Zn}$ \\
\hline JA045M & 10.3 & $<1.2(<12)$ & $46(450)$ & $0.1(<1)$ & $39(380)$ & $4.3(42)$ & $37(360)$ \\
JA161M & 14.2 & $<1.1(<8)$ & $31(220)$ & $1.2(8.5)$ & $45(320)$ & $4.7(33)$ & $130(890)$ \\
JA163M & 22.2 & $<1.8(<8)$ & $56(250)$ & $1.3(5.8)$ & $47(210)$ & $6.0(27)$ & $120(520)$ \\
JA165M & 42.3 & $10 .(24)$ & $280(670)$ & $5.5(13)$ & $59(140)$ & $34(80)$ & $330(770)$ \\
JA166M & 46.3 & $<4 .(<8)$ & $150(330)$ & $5.6(12)$ & $110(232) 46(99)$ & $520(1100)$
\end{tabular}

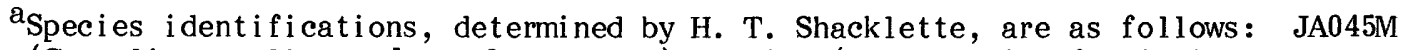
(Campyli um stellatum [Hedw.] C. Jens.); JA161M (Amblystegium fluviatile var. noterophyllum [Sul1. < Lesq.] Flow.); JA163M (same as JA161M); JA165M (same as JA045M); and JA166M (Brachy thecium rivulare B.S.G.).

${ }^{\mathrm{b}}$ JA045M represents a regional background sample. It was collected from the northwest corner of Doug las Island near the mouth of Cove Creek, beyond any known source of mineralization. Except for $\mathrm{Cu}$, its composition is widely divergent from that of a sample (JA165M) of the same species taken at the mouth of Big Sore Creek (fig. 64). Effects of species differences have been discounted by Erdman and Modreski (1984); comparisons with samples of other species are equally valid. 
Sainsbury, C. L., Curry, K. J., and Hamilton, J. C., 1973, An integrated system of geologic mapping and geochemical sampling by light aircraft: U.S. Geological Survey Bulletin 1361, 28 p.

Smith, D. C., 1976, Storvatnet and Rettbakkenmoss-trapped stream sediment material as a prospecting medium: Journal of Geochemical Exploration, v. 5, p. 338-341.

Reviewers: Theodore Botinelly and Barbara McConnell.

\section{CHEMICAL ZONATION OF GARNET IN PELITIC ROCKS OF THE COAST PLUTONIC-METAMORPHIC COMPLEX NEAR JUNEAU}

\section{by Glen R. Himmelberg, Arthur B. Ford, David A. Brew, and Stephen Van Horn}

A large number of studies have dealt with the chemical zonation of garnet in metamorphic rocks. (See Tracy, 1982, for a review of this topic.) Although a general pattern of behavior has been established, it has also become obvious that there are differences in zoning details that reflect differences in the evolution of metamorphic terranes (Tracy, 1982; Spear and Selverstone, 1983; Spear and others, 1984). This report describes initial studies of chemical zonation of garnet in eight samples of pelitic schist from the Coast plutonicmetamorphic complex along Blackerby Ridge near Juneau (fig. 62). This metamorphic terrane contains mineral assemblages that range from those of the prehnite-pumpellyite metagraywacke facies to those of the upper amphibolite facies. The first appearances of the Barrovian index minerals biotite, garnet, staurolite, kyanite, and sillimanite, which were first documented by Forbes (1959) and mapped over an extensive area of the Coast plutonic-metamorphic complex by Ford and Brew $(1973,1977)$ and Brew and Ford (1977), recently were shown to mark the occurrence of particular model reactions and are, thus, true reaction isograds (Himmelberg, Ford, and Brew, 1984).

In general, garnet zoning patterns are of two types (Tracy, 1982): (1) growth zoning that developed because of a continuous or discontinuous change in composition of the material supplied to the growing crystal; and (2), diffusion zoning that is imposed upon a preexisting crystal through intracrystalline diffusion. At Blackerby Ridge, garnet from the garnet zone into the upper kyanite zone is characterized by growth zoning. (See Himmelberg and others, 1984, for mineral assemblages and AFM topology characteristics of each zone.) The growth zoning pattern consists of decreasing $\mathrm{X}_{\mathrm{Mn}}$ $\left(\mathrm{Mn} /(\mathrm{Fe}+\mathrm{Mg}+\mathrm{Mn})\right.$ and $\mathrm{X}_{\mathrm{Ca}}(\mathrm{Ca} /(\mathrm{Fe}+\mathrm{Mg}+\mathrm{Ca})$, and increasing $\mathrm{X}_{\mathrm{Mg}}$, from the core of the garnet toward the rim. In addition, growth zoning patterns in samples of the staurolite to upper kyanite zone show a reversal in $\mathrm{X}_{\mathrm{Mn}}$, and in some cases $\mathrm{X}_{\mathrm{Ca}}$, at the rim of the garnet. These reversals are generally restricted to 0.1 to $0.2 \mathrm{~mm}$ inward from the grain boundary.

The smooth zoning curve of $\mathrm{Mn}$ (and $\mathrm{Ca}$ ) depletion and $\mathrm{Mg}$ enrichment for garnet in the garnet zone is similar to zoning patterns reported for garnet in other pelitic schists of kyanite and lower grades (for example, Hollister, 1966; Guidotti, 1974; Tracy and others, 1976; Crawford, 1977; Thompson and others, 1977) and is interpreted to indicate garnet growth during a single prograde reaction where $\mathrm{Mn}$ (and $\mathrm{Ca}$ ) is strongly fractionated into the garnet at the beginning of its growth and $\mathrm{Mg}$ is enriched in the garnet during growth with increasing temperature. Mineral assemblage data suggest that for the Blackerby Ridge garnet the reaction was

$$
\begin{gathered}
\text { Chlorite + Muscovite }+ \text { Quartz }= \\
\text { Garnet }+ \text { Biotite }+\mathrm{H}_{2} \mathrm{O}(1),
\end{gathered}
$$

which is a continuous reaction and would result in the garnet becoming progressively enriched in $\mathrm{Mg}$ with increasing temperature (Thompson, 1976).

The growth zoning pattern in the staurolite to upper kyanite zone presumably indicates a more complex history. Much of the zoning path is similar to that in the garnet zone, suggesting growth during reaction (1). The reversal in zoning pattern (Mn enrichment) near the rim may be a result of the prograde reaction

$$
\begin{aligned}
& \text { Chlorite + Muscovite + Quartz }= \\
& \text { Staurolite + Biotite + Quartz }+\mathrm{H}_{2} \mathrm{O}(2),
\end{aligned}
$$

which is the reaction isograd between the garnet and staurolite zones (Himmelberg and others, 1984). This reaction would result in resorption of garnet, which could effectively concentrate $\mathrm{Mn}$ in the garnet rim, since $\mathrm{Mn}$ is preferentially fractionated into the garnet relative to the product phases (Thompson, 1976). Garnets with the reversed growth zoning pattern commonly show irregular, embayed grain boundaries, supporting the interpretation of reaction resorption.

Garnets in the uppermost kyanite zone and the sillimanite zone exhibit diffusion zoning. These garnets are, for the most part, relatively homogeneous or weakly zoned, with a narrow rim that has a slightly increasing $X_{M n}$ and generally decreasing $\mathrm{X}_{\mathrm{Mg}}$. The zoning pattern is similar to diffusion zoned garnets in sillimanite grade rocks of other metamorphic terranes (Grant and Weiblen, 1971; Hollister, 1977; Woodsworth, 1977). The near homogeneous composition of these higher grade garnets is at tributed to the rate of volume diffusion exceeding the rate of crystal growth at the temperatures of sillimanite-grade metamorphism (Tracy and others, 1976; Woodsworth, 1977). As suggested by Tracy (1982), the concentration of $\mathrm{Mn}$ in the rim of 
some garnets is probably a result of retrograde resorption of the garnet with fractionation of the Mn into the garnet $\mathrm{rim}$ and $\mathrm{Mg}$ into a retrograde product, presumably biotite.

Using garnet-biotite geothermometry (Ferry and Spear, 1978), the change from growth zoning to diffusion zoning occurs between about $605^{\circ}$ and $690^{\circ} \mathrm{C}$.

\section{REFERENCES CITED}

Brew, D. A., and Ford, A. B., 1977, Preliminary geologic and metamorphic-isograd map of the Juneau B-1 Quadrangle, Alaska: U.S. Geological Survey Miscellaneous Field Studies Map MF-846, 1 sheet, scale $1: 31,680$.

Crawford, M. L., 1977, Calcium zoning in almandine garnet, Wissahickon Formation, Philadelphia, Pennsylvania: Canadian Mineralogist, v. 15, p. 243-249.

Ferry, J. M., and Spear, F. S., 1978, Experimental calibration of the partitioning of $\mathrm{Fe}$ and $\mathrm{Mg}$ between biotite and garnet: Contributions to Mineralogy and Petrology, v. 66, p. 113-117.

Forbes, R. B., 1959, The bedrock geology and petrology of the Juneau Ice Field area, southeastern Alaska: Seattle, Wash., University of Washington, Ph.D. dissertation, $260 \mathrm{p}$.

Ford, A. B., and Brew, D. A., 1973, Preliminary geologic and metamorphic-isograd map of the Juneau B-2 Quadrangle, Alaska: U.S. Geological Survey Miscellaneous Field Studies Map MF-527, 1 sheet, scale 1:31,680.

Ford, A. B., and Brew, D. A., 1977, Preliminary geologic and metamorphic-isograd map of the northern parts of the Juneau A-1 and A-2 Quadrangles, Alaska: U.S. Geological Survey Miscellaneous Field Studies Map MF-847, scales $1: 31,680$ and $1: 250,000$..

Grant, J. A., and Weiblen, P. W., 1971, Retrograde zoning in garnet near the 2nd sillimanite isograd: American Journal of Science, v. 270, p. 281-296.

Guidotti, V. A., 1974, Transition from staurolite to sillimanite zone, Rangeley Quadrangle, Maine: Geological Society of America Bulletin, v. 85, p. 465-490.

Himmelberg, G. R., Ford, A. B., and Brew, D. A., 1984, Reaction isograds in pelitic rocks of the Coast plutonic-metamorphic complex near Juneau, in Reed, K. M., and BartschWinkler, Susan, eds., The United States Geological Survey in Alaska -Accomplishments during 1982: U.S. Geological Survey Circular 939, p. 105-108.

Hollister, L. S., 1966, Garnet zoning-An interpretation based on the Rayleigh fractionation model: Science, v. 154, p. 1647-1651.

Hollister, L. S., 1977, The reaction forming cordierite from garnet, the Khtada Lake metamorphic complex, British Columbia: Canadian Mineralogist, v. 15, p. 217-229.
Spear, F. S., and Selverstone, J., 1983, Quantitive $\mathrm{P}-\mathrm{T}$ paths from zoned minerals-Theory and tectonic application: Contributions to Mineralogy and Petrology, v. 83, p. 348-357.

Spear, F. S., Selverstone, J., Hickmott, D., Crowley, P., and Hodges, K. V., 1984, P-T paths from garnet zoning - A new technique for deciphering tectonic processes in crystalline terranes: Geology, v. 12, p. 87-90.

Thompson, A. B., 1976, Mineral reactions in pelitic rocks: I. Prediction of $\mathrm{P}-\mathrm{T}-\mathrm{X}(\mathrm{Fe}-\mathrm{Mg})$ phase relations: American Journal of Science, $v$. 276, p. 401-424.

Thompson, A. B., Tracy, R. J., Lyttle, P. T., and Thompson, J. B., Jr., 1977, Prograde reaction histories deduced from compositional zonation and mineral inclusions in garnet from the Gassetts Schist, Vermont: American Journal of Science, v. 277, p. 1152-1167.

Tracy, R. J., 1982, Compositional zoning and inclusions in metamorphic minerals, in Ferry, J.M., ed., Characterization of metamorphism through mineral equilibria: Mineralogical Society of America, Reviews in Mineralogy, v. 10, p. 355-397.

Tracy, R. J., Robinson, Peter, and Thompson, A. B., 1976, Garnet composition and zoning in the determination of temperature and pressure of metamorphism, central Massachusetts: American Mineralogist, v. 61, p. 762-775.

Woodsworth, G. J., 1977, Homogenization of zoned garnets from pelitic schists: Canadian Mineralogist, v. 15, p. 230-242.

Reviewers: Cynthia Dusel-Bacon and S. L. Douglass

\section{LACK OF RELATION BETWEEN THE TIDAL-FLAT EN VIRONM ENT AND UPSTR EAM MINERALIZATION, PETERSBURG QUADRANGLE}

\section{by Lorraine H. Filipek, Theodore Botinelly, and Walter H. Ficklin}

Increased metal concentrations were found in estuarine waters from tidal flats receiving drainage from mineralized areas in the Petersburg Quadrangle (Filipek, 1984). These results generated interest in using samples collected from easily accessible tidal flats for reconnaissance exploration rather than samples collected upstream in rugged and heavily vegetated terrain. In 1982 and 1983, therefore, further investigations of the tidal-flat environment were conducted. The results of these later investigations indicate that neither sediment nor water collected from tidal flats makes an effective exploration medium due to the variety of physical and chemical processes that occur in this environment.

The drainage sediments in the Petersburg Quadrangle appear to be diluted on the tidal flats by fine material transported in from outside sources. 
Near Petersburg, large volumes of glacial flour are transported as suspended matter from the Stikine River into the neighboring straits. The strong tidal currents transport the flour large distances, with the result that fine sediment collected from several tidal flats on Zarembo, Kuiu, and Kupreanof Islands (fig. 65) could not be distinguished from Stikine River suspended matter on the basis of mineralogy, using X-ray diffraction and optical techniques.

The $\mathrm{Cu}$ concentrations in minus-80 mesh sediments of several tidal flats show large variations over the flat. For example, the $\mathrm{Cu}$ concentrations in sediments of Kadake Bay, Kuiu Island (fig. 66) are low compared to stream sediments above tidal influence. In contrast, Meter Bight sediments (Zarembo Island) (fig. 67) have higher $\mathrm{Cu}$ concentrations, for the most part, than sediments from streams draining into the Bight.

Dissolved metal concentrations in water from the tidal-flat environment have no relation to mineralization upstream. Rather, the estuarine $\mathrm{Cu}$ and $\mathrm{Zn}$ concentrations, for the most part, are positively correlated with salinity (fig. 68). As discussed by Filipek (1984), this positive correlation contrasts with most published results (Sholkovitz, 1978; Sholkovitz and others, 1978), which show that heavy metal concentrations in water decrease as salinity increases, due to flocculation of iron oxide and organic colloids. The increase of $\mathrm{Cu}$ and $\mathrm{Zn}$ with salinity in this study is a local phenomenon. Because of the high rainfall and rugged glaciated terrain of southeast Alaska, streams are fast flowing and thus quite low in metal content. The $\mathrm{Cu}$ and $\mathrm{Zn}$ concentrations in southeast Alaska stream waters are lower than the average concentrations in sea water in the southeast Alaska straits (Filipek and Ficklin, 1983), and these elements exist mainly in true solution, rather than associated with colloids. As the stream water and sea water mix on the tidal flats, their dissolved metals also mix.

An additional source of dissolved $\mathrm{Cu}$ on the tidal flats is the $\mathrm{Cu}$ released during diagenetic remobilization (Filipek and Ficklin, 1983). Based on examination of cores from three tidal flats, it appears that dissolution of $\mathrm{Cu}$ occurs at sediment depths of about $1-10 \mathrm{~cm}$, probably due to breakdown

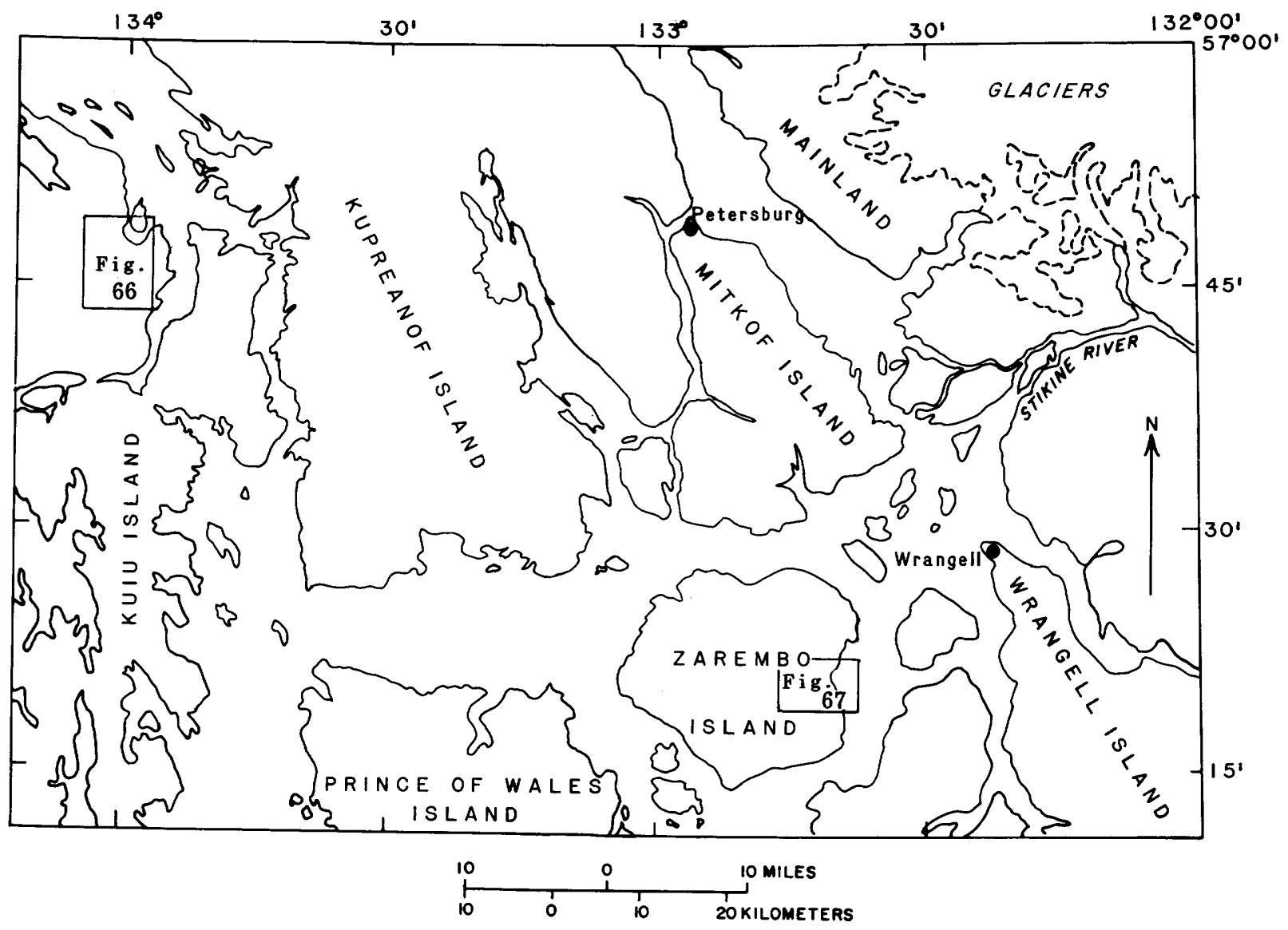

Figure 65.--Map of study area, which includes most of the Petersburg Quadrangle and the easternmost part of the Port Alexander Quadrangle. Areas enclosed in boxes are shown in figures 66 and 67. 
of organic matter. Some of the dissolved $\mathrm{Cu}$ appears to diffuse into the overlying water column, some reprecipitates in the uppermost sediment, and some diffuses downward to precipitate as $\mathrm{Cu}$ bearing sulfides below about $15 \mathrm{~cm}$. It is likely that less than 10 percent of the $\mathrm{Cu}$ in the sediment actually escapes into the overlying tidal-flat water, based on comparison of $\mathrm{Cu}$ concentrations in stream and tidal-flat sediments.

In summary, a variety of physical and chemical processes occur in the tidal-flat environment of the Petersburg Quadrangle, and probably throughout southeast Alaska. These processes include transport of fine materials from exogenous sources, diagenetic remobilization of some ore metals, and authigenic precipitation of metal sulfides. From a scientific viewpoint, the tidal-flat environment offers a host of research possibilities. However, from a reconnaissance exploration viewpoint, the tidal flats are too complex to provide a meaningful picture of mineralization in the upstream drainage basin.

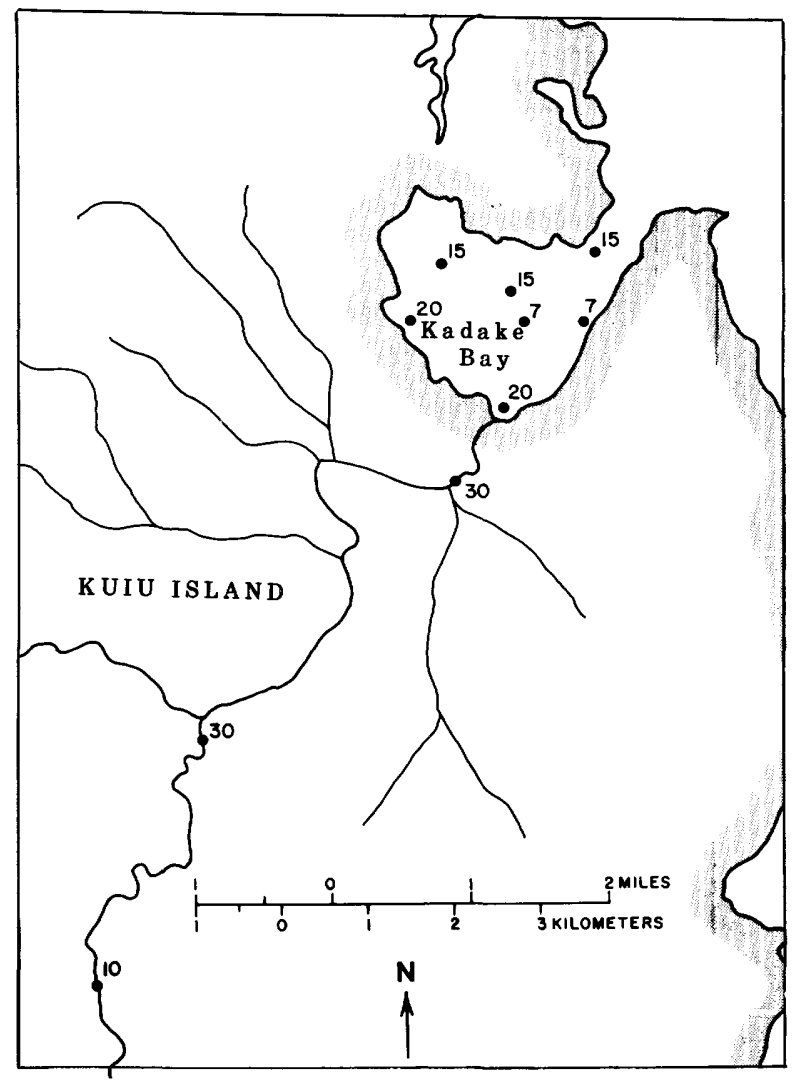

Figure 66.--Drainage into Kadake Bay, Kuiu Island. Sample locations of minus-80 mesh stream and mudflat sediments are shown by dots; numbers indicate total $\mathrm{Cu}$ concentration in parts per million.

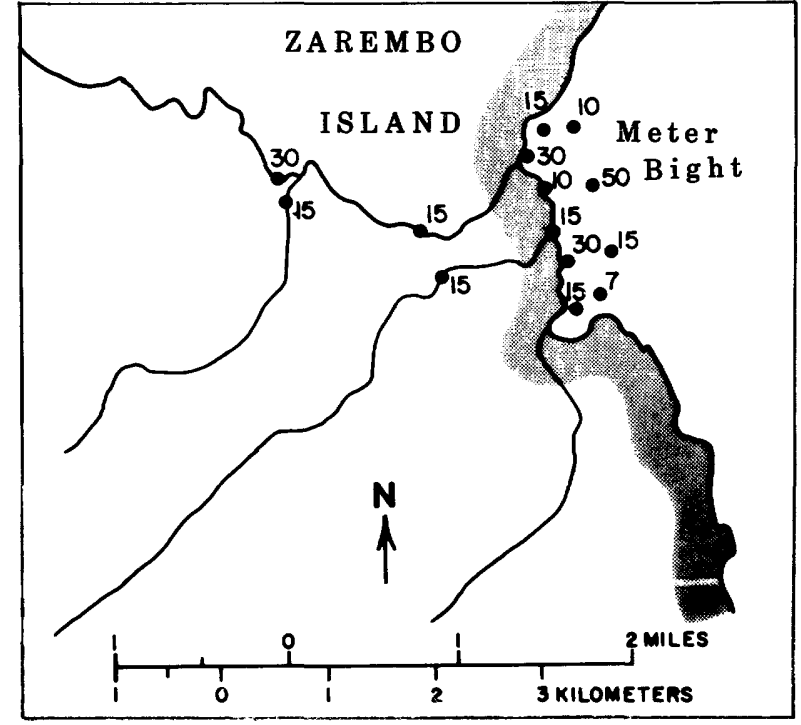

Figure 67.--Drainage into Meter Bight, Zarembo Island. Sample locations of minus -80 mesh stream and mudflat sediments are shown by dots; numbers indicate total $\mathrm{Cu}$ concentration in parts per million.

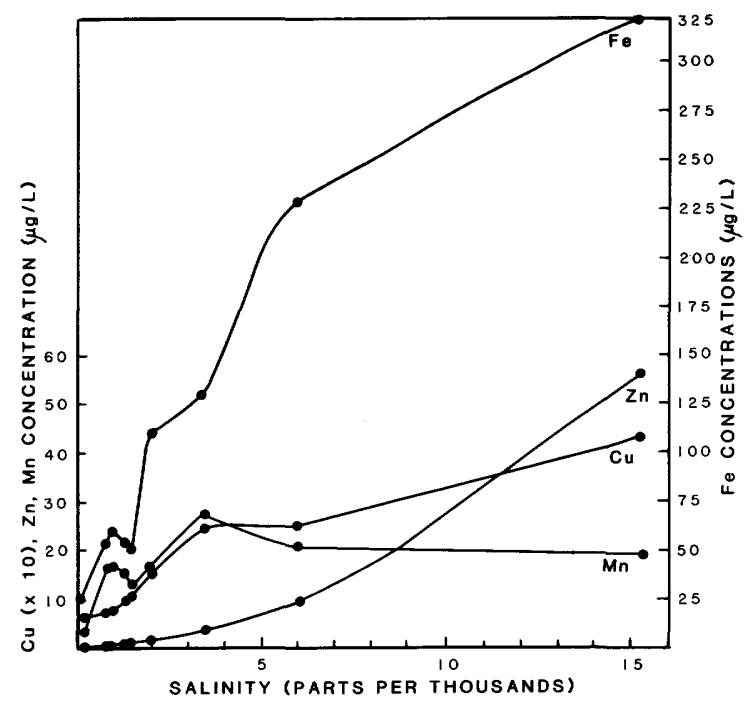

Figure 68.--Dissolved (less than 0.45 microns) metal concentrations as a function of salinity in water from St. John Harbor, Zarembo Island. The water was collected at a single location at different tidal stages. 


\section{REFERENCES CITED}

Filipek, L. H., 1984, The possible significance of diagenetic remobilization of ore elements in mud-flat estuarine environments, in Reed, Katherine $M$. and Bartsch-Winkler, Susan, eds., The United States Geological Survey in Alaska-Accomplishments during 1982: U.S. Geological Survey Circular 939, p. 96-100.

Filipek, L. H., and Ficklin, W. H., 1983, Elevated copper and zinc concentrations in southeast Alaska seawater due to diagenetic remobilization (abs.): Geological Society of America Annual Meeting, Indianapolis, Indiana, Abstracts with Programs, v. 15, no. 6, p. 571 .

Sholkovitz, E. R., Boyle, E. A., and Price N. B., 1978, The removal of dissolved humic acids and iron during estuarine mixing: Earth and Planetary Science Letters, v. 40, p. 130-136.

Sholkovitz, E. R., 1978, The flocculation of dissolved $\mathrm{Fe}, \mathrm{Mn}, \mathrm{Al}, \mathrm{Cu}, \mathrm{Ni}, \mathrm{Co}$, and $\mathrm{Cd}$ during estuarine mixing: Earth and Planetary Science Letters, v. 41, p. 77-86.

Reviewers: J. B. Cathrall and C. L. Smith

\section{LEAD ISOTOPES FROM \\ VOLCANOGENC MASSIVE SULFIDE DEPOSITS IN THE ALEXANDER TERRANE}

\section{by Anne P. LeHuray, Harold S. Stowell, and Stanley E. Church}

Complexly deformed and metamorphosed sedimentary, volcanic, and intrusive rocks ranging in age from pre-Ordovician to Cenozoic comprise much of western Canada and southeastern Alaska. Two volcanogenic massive sulfide deposits from this region-the Greens Creek and the Sweetheart Ridge deposits-were sampled for $\mathrm{Pb}$-isotopic analysis. In general, $\mathrm{Pb}$-isotopic data from volcanogenic massive sulfide deposits reflect the interaction of ensimatic volcanism with the crust. There may be little influence of mantle-derived $\mathrm{Pb}$ in the $\mathrm{Pb}$-isotopic data from volcanogenic massive sulfide deposits associated with continental margin volcanism. Rather, the $\mathrm{Pb}$-isotopic data represent $\mathrm{Pb}$ from a crustal reservoir (Doe and Zartman, 1979). Ore-leads that fall above the regression line for mid-ocean ridge basalts (MORB, fig. 69) reflect a mixing process between the mantle and the crust.

The volcanogenic massive sulfide deposit at Greens Creek, at the northwest end of Admiralty Island, occurs in felsic and intermediate metatuff intercalated with carbonaceous phyllite and argillite. The deposit is a stratabound $\mathrm{Zn}-\mathrm{Pb}-\mathrm{Ag}-$ $(-\mathrm{Cu}-\mathrm{Au})$-barite lode that occurs in strata possibly as old as Devonian (Berg and others, 1978) or as young as late Triassic (Berg and Grybeck, 1980). The isotopic composition of $\mathrm{Pb}$ from a single galena sample from this deposit has the following composition:

$$
\begin{aligned}
& { }^{206} \mathrm{~Pb} /{ }^{204} \mathrm{~Pb}=18.670 ;{ }^{207} \mathrm{~Pb} /{ }^{204} \mathrm{~Pb}=15.610 ; \\
& { }^{208} \mathrm{~Pb} /{ }^{204} \mathrm{~Pb}=38.45 .
\end{aligned}
$$

The Sweetheart Ridge deposit, situated about $60 \mathrm{~km}$ southeast of Juneau in the Sumdum D-6 Quadrangle, occurs in metavolcanic schist of original probable Permian or Triassic age (Brew and others, 1977). The deposit, described by Stowell (1981), contains $\mathrm{Au}-\mathrm{Cu}-\mathrm{Zn}-\mathrm{Pb}$ mineralization; both the stratigraphic and geochemical data support a volcanogenic origin. Two samples of galena from the deposits were analyzed, giving: ${ }^{206} \mathrm{~Pb} /{ }^{204} \mathrm{~Pb}=$ 18.876; ${ }^{207} \mathrm{~Pb} /{ }^{204} \mathrm{~Pb}=15.659 ;{ }^{208} \mathrm{~Pb} /{ }^{204} \mathrm{~Pb}=38.54$; the results differed only within analytical error $(0.1$ percent/mass unit). Geologic studies indicate that the deposit was metamorphosed, probably during Cretaceous time (Brew and others, 1977). Galena from a quartz vein that crosscuts the enclosing strata near the Sweetheart Ridge deposit has the following composition: $\quad{ }^{206} \mathrm{~Pb} /{ }^{204} \mathrm{~Pb}=18.963$; ${ }^{207} \mathrm{~Pb} /{ }^{204} \mathrm{~Pb}=15.671 ;{ }^{208} \mathrm{~Pb} /{ }^{204} \mathrm{~Pb}=38.65$.

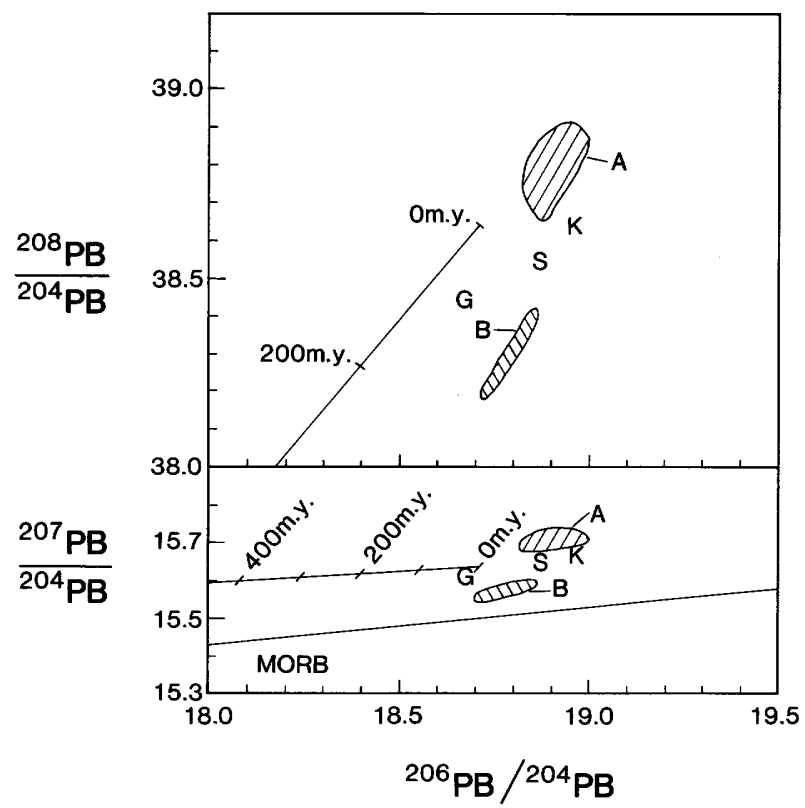

Figure 69.-Diagram from LeHuray and others (1985) showing the Pb-isotopic data from volcanogenic massive sulfides from the Sweetheart Ridge (S) and the Greens Creek (G) deposits and from a crosscutting quartz vein $(\mathrm{K})$. The $\mathrm{Pb}$ isotopic composition of the mantle is represented by the MORB regression line (Church and Tatsumoto, 1975). Field A represents the $\mathrm{Pb}$-isotopic data observed from the Jarvis Creek Glacier terrane north of the Denali fault in the Mount Hayes Quadrangle; B represents the data from the Wrangellia terrane south of the Denali fault (LeHuray and others, 1985). 
The Pb-isotopic data from these two volcanogenic-massive sulfide deposits, the Sweetheart Ridge and Greens Creek deposits, if compared with the $\mathrm{Pb}$-isotope growth curve, indicate that the $\mathrm{Pb}$ formed in a ${ }^{238} \mathrm{U} /{ }^{204} \mathrm{~Pb}$ environment typical of upper crustal rocks. The ${ }^{207} \mathrm{~Pb} /{ }^{204} \mathrm{~Pb}$ ratios are high relative to MORB, and the $\mathrm{Pb}$-isotopic data for both the Greens Creek and Sweetheart Ridge deposits plot to the right of the 200-m.y. isochron (fig. 69). Assuming that both deposits are Permian or Triassic in age (Berg and Grybeck, 1980), the $\mathrm{Pb}$-isotopic results would suggest that the deposits formed by mixing with different crustal $\mathrm{Pb}$-isotopic reservoirs and perhaps are not a part of the same tectonostratigraphic terrane (Berg and others, 1978). However, if the Greens Creek deposit is as old as Devonian (Berg and others, 1978), the $\mathrm{Pb}$-isotopic results may be compatible with formation in the same tectonostratigraphic terrane (Brew and Ford, 1984). That is, the two deposits may have formed by mixing of mantle $\mathrm{Pb}$ with sediment-derived $\mathrm{Pb}$ from the same upper crustal $\mathrm{Pb}$-isotope reservoir. The separation of $\mathrm{Pb}$-isotopic signatures from the two deposits (fig. 69 ) is approximately as expected from radiogenic growth of $\mathrm{Pb}$ over a 100-150-m.y. (Devonian to Permian or Triassic) period in an upper crustal reservoir of recycled sediment. The difference in $\mathrm{Pb}$-isotopic composition of the Sweetheart Ridge deposit and the galena from the crosscutting quartz vein can be readily explained by radiogenic growth from the time of deposition (Permian or Triassic) to the time of metamorphism (Cretaceous).

Finally, a comparison of the $\mathrm{Pb}$-isotopic signature of the volcanogenic massive sulfide deposits from Greens Creek and Sweetheart Ridge with those from the Devonian Jarvis Creek Glacier terrane (A, fig. 69) and the Permian or Triassic Wrangellia terrane (B, fig. 69) from the Mount Hayes Quadrangle about $1,000 \mathrm{~km}$ to the northwest indicates that these two deposits represent upper crustal reservoirs having different $\mathrm{Pb}$-isotopic signatures. In each case, the ores give a potentially unique $\mathrm{Pb}$-isotopic signature for deposits of a specific geologic age. Application of $\mathrm{Pb}$-isotopes to fingerprint ore deposits may prove useful in unraveling the current tectonostratigraphic melange in Alaska.

\section{REFERENCES CITED}

Berg, H. C., and Grybeck, D. L., 1980, Upper Triassic volcanogenic $\mathrm{Zn}-\mathrm{Pb}-\mathrm{Ag}(-\mathrm{Cu}-\mathrm{Au})-$ barite mineral deposits near Petersburg, Alaska: U.S. Geological Survey Open-File Report 80-527, 7 p.

Berg, H. C., Jones, D. L., and Coney, P. J., 1978, Pre-Cenozoic tectonostratigraphic terranes of southeastern Alaska and adjacent areas: U.S. Geological Survey Open-File Report 78-1085.
Brew, D. A., and Ford, A. B., 1984, Tectonostratigraphic terranes in the Coast plutonic-metamorphic complex, southeastern Alaska in Reed, K. M., and Bartsch-Winkler, Susan, eds., The United States Geological Survey in Alaska-Accomplishments during 1982: U.S. Geological Survey Circular 939, p. 90-93.

Brew, D. A., Grybeck, Donald, Johnson, B. R., Jachens, R. C., Nutt, C. J., Barnes, D. F., Kimball, A. L., Still, J. C., and Rataj, J. L., 1977, Mineral resources of the Tracy ArmFords Terror wilderness study area and vicinity, Alaska: U.S. Geological Survey OpenFile Report 77-649, 300 p.

Church, S. E., and Tatsumoto, Mitsunobu, 1975, $\mathrm{Pb}$ isotope relations in oceanic basalts from the Juan de Fuca-Gorda Rise area, N.E. Pacific Ocean: Contributions to Mineralogy and Petrology, v. 53, p. 253-279.

Doe, B. R., and Zartman, R. E., 1979, Plumbotectonics: the Phanerozoic, in Barnes, H. L., ed., Geochemistry of Hydrothermal Ore Deposits (2d ed.): New York, Wiley-Interscience, p. 22-70.

LeHuray, A. P., Church, S. E., and Nokleberg, W. J., 1985, Lead isotopes in sulfide deposits from the Jarvis Creek Glacier and Wrangellia terranes, Mount Hayes Quadrangle, eastern Alaska Range, Alaska: this volume.

Stowell, H. S., 1981, The geology of Sweetheart Ridge and adjacent areas, southeastern Alaska: Columbia, University of South Carolina, M. S. thesis, 110 p.

Reviewers: J. N. Aleinikoff, T. D. Light, and H. C. Berg

\section{SPHALERITE GEOBAROMETRY IN THE COAST RANGE MEGALINEAMENT ZONE NEAR HOLKHAM BAY}

\section{by Harold Stowell 1}

The purpose of this note is to report preliminary results of a study of sphalerite geobarometry based on samples from the Holkham Bay area and to provide a comparison of these results with what is known about metamorphic pressures based on metamorphic silicate minerals.

The Coast Range megalineament zone (CRM) is a prominent zone of faults and well developed foliation paralleling the Coast plutonic complex in southeastern Alaska and British Columbia (Brew and Ford, 1978; Crawford and Hollister, 1982), which is defined here to include all of the steeply dipping, folded and faulted metamorphic rocks between Stephens Passage and the foliated tonalite of the western Coast Plutonic Complex (figs. 70a, b).

1 Department of Geological and Geophysical Science, Princeton Univ., Princeton, NJ 08544 


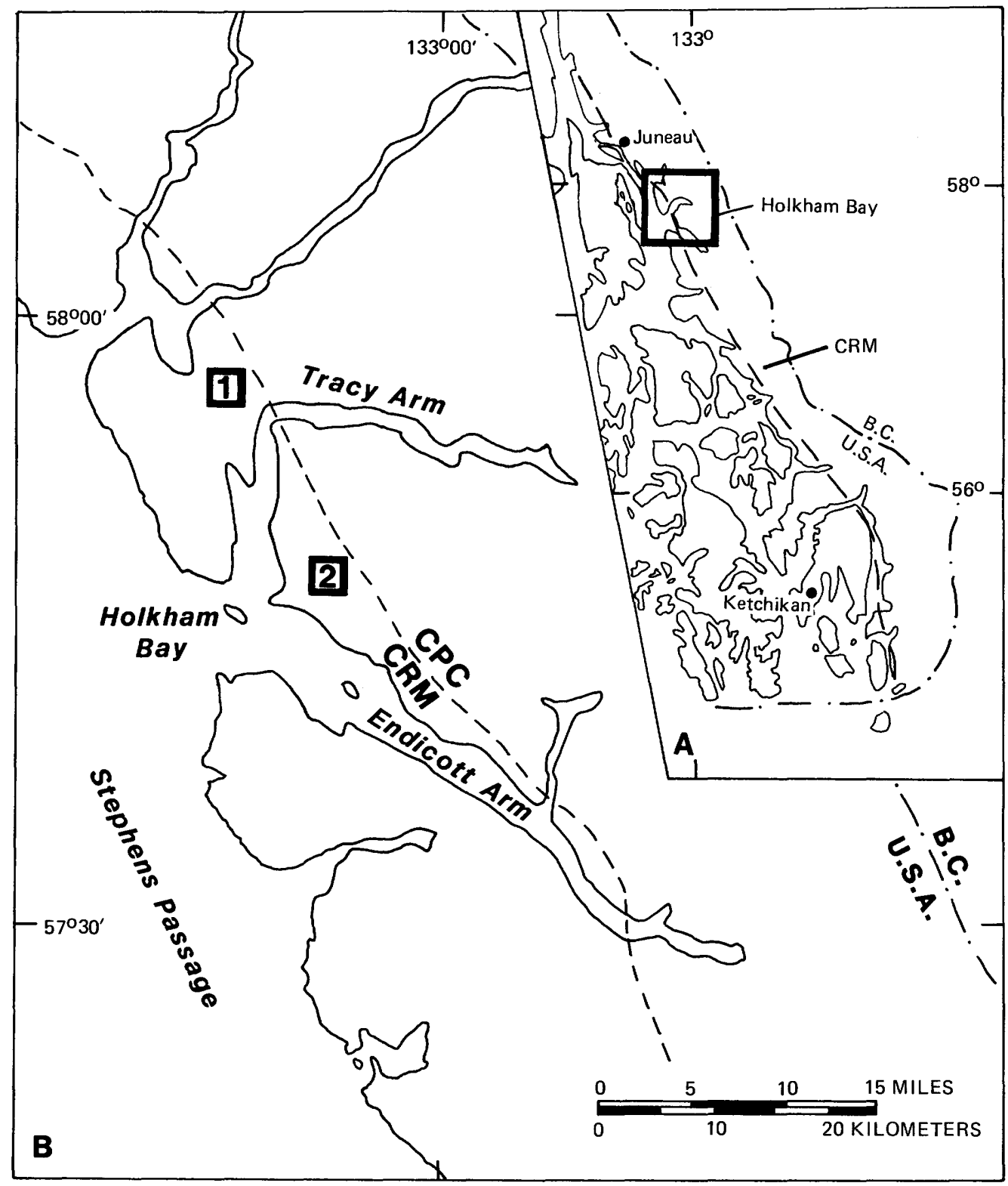

Figure 70.--(A) Location of the Holkham Bay area in southeastern Alaska. (B) Map of Holkham Bay including the western contact of the Coast plutonic complex (CPC), the Coast Range megalineament zone (CRM), and the Sweetheart (1) and Sumdum (2) prospects.

These rocks are part of the Taku terrane (Berg and others, 1978; Jones and others, 1981), are inferred to be of original Permian and Triassic age (Brew and others, 1977), and to have been metamorphosed in Late Cretaceous or early Tertiary time (Brew, 1983). Metamorphic grade increases from west to east, ranging from chlorite to staurolite and kyanite zones in the Holkham Bay area (Stowell, 1981).
Numerous subvertical faults of unknown displacement are subparallel to the CRM and to the isograds, possibly modifying the original spatial relations between the metamorphic mineral assemblages.

The sphalerite geobarometer has been experimentally calibrated and tested on naturally occurring pyrite, pyrrhotite, and sphalerite assem- 
blages (Scott and Barnes, 1971; Scott, 1976; Hutchison and Scott, 1980). Although the barometer has been criticized as being more temperature dependent at low temperatures than originally proposed (P. B. Barton, U.S. Geological Survey, oral commun., 1984) and subject to error due to disequilibrium during or after peak metamorphic conditions (Brown and others, 1978), metamorphic conditions can be constrained by the FeS content of sphalerite coexisting with pyrite and pyrrhotite (Hutchison and Scott, 1980). Several studies of natural sulfide assemblages have shown that differences in FeS content can be present between sphalerite in contact with only pyrite, with only pyrrhotite, or with both minerals (Brown and others, 1978; Hutchison and Scott, 1980). This implies that equilibrium might be present only along grain contacts.

Both the Sumdum copper-zinc prospect (MacKevett and Blake, 1964) and Sweetheart Ridge gold prospect (fig. 70b; Brew and others, 1977) contain lenses of massive and disseminated sulfide minerals that are parallel to metamorphic layering and bedding and that are interpreted to have been conformable prior to deformation (Brew and others, 1977; Stowell, 1981). The Sweetheart Ridge prospect occurs in staurolite-kyanite zone schist and gneiss. These rocks are inferred to have crystallized at $550^{\circ} \mathrm{C}$ at $4.3 \mathrm{~kb}$ based on (1) the apparent equilibrium of staurolite with biotite but not with chlorite or white mica (Hoschek, 1969), (2) preliminary results from biotite-garnet geothermometry, and (3) the presence of kyanite and absence of sillimanite and andalusite. The Sumdum prospect is in similar staurolite schist, which, however, lacks kyanite.

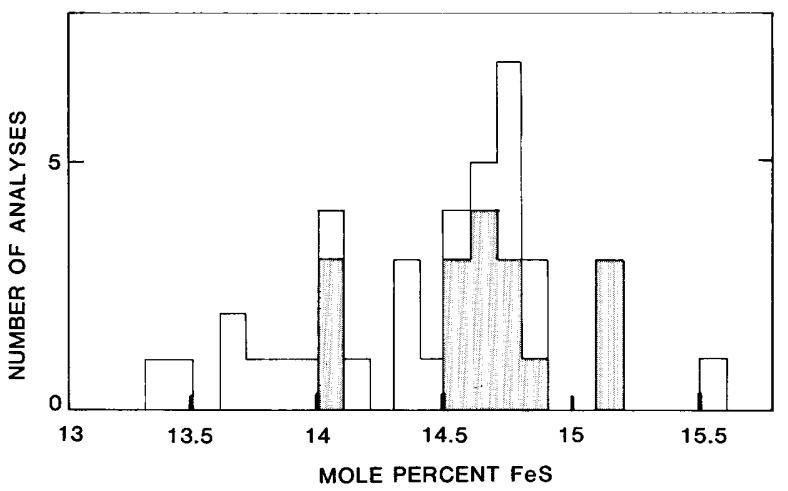

Figure 71.--Histogram of $\mathrm{FeS}$ content in sphalerite from the Sumdum prospect. The mode for analyses of grains in contact with pyrite and pyrrhotite (stippled pattern) is not significantly different from the mode for all analyses. Analyses reported here are averages of up to fifty, 10-second, wavelength dispersive microprobe analyses over single grain areas of up to several $\mathrm{mm}^{2}$ where no compositional zonation was found. The FeS content chosen to represent metamorphic conditions is 14.7 mole percent.
Electron microprobe analyses were taken at 5-micron or smaller intervals across sphalerite, pyrite, and pyrrhotite grains to test for zonation and inhomogeneity. Results show that the FeS content of sphalerite (1) generally does not vary more than one mole percent within grains (all less than 2 mole percent), (2) commonly remains constant from the center of a grain to a pyrrhotite-sphalerite contact, and (3) in many instances decreases slightly from the center of a grain to a pyrite-sphalerite contact.

All the sphalerite grains from the Sumdum prospect have similar FeS content-all but 10 of 39 grains analyzed contain between 13.9 and 14.9 mole percent FeS. A histogram of mole percent FeS content for the analyzed sphalerite grains shows a mode at 14.75 mole percent $\mathrm{FeS}$ (fig. 71, all analyses).

The consistent values of FeS content, both in and among almost all the sphalerite grains from the Sumdum prospect, and their granular texture probably result from equilibrium at tained during metamorphism, because partial re-equilibration should have resulted in more prominent compositional gradients within grains than were observed. Also, greater differences in composition among grains would be expected if disequilibrium were important (due to differences in the activity of $\mathrm{FeS}$ ). The mode for all analyses was used to calculate a pressure of $4.9 \pm 0.4 \mathrm{~kb}$ from an equation derived by Priestly Toulmin (P. B. Barton, oral commun., 1984). An estimated metamorphic temperature of $550^{\circ} \mathrm{C}$ was derived from the silicate minerals.

The FeS content of six sphalerite grains from the Sweetheart Ridge prospect ranges from 13.7 to 14.6 mole percent FeS. These preliminary results indicated that the pressure of sulfide equilibration at Sweetheart Ridge was similar to that at the Sumdum prospect, which is about $17 \mathrm{~km}$ away and nearly on strike with regional structures.

Pressures calculated from the sphalerite geobarometer of $4.9 \pm 0.4 \mathrm{~kb}$, using the analyses from the Sumdum prospect, are compatible with pressures estimated from kyanite-staurolite zone minerals found on Sweetheart Ridge. The values are valid if the geobarometer is temperature independent, as originally proposed, or if a temperature of $550^{\circ} \mathrm{C}$ is used to calculate the pressure. However, if the sulfide minerals equilibrated after the silicate minerals and the geobarometer is as temperature dependent as is proposed by P. B. Barton, the FeS content of the sphalerite grains could indicate a late metamorphic pressure as low as $3 \mathrm{~kb}$ at $300^{\circ} \mathrm{C}$. Although the geobarometer may well be temperature dependent, it seems likely that the higher pressures and temperatures are correct for the eastern part of the CRM when the equilibrium metamorphic textures, lack of large inhomogeneities both within and among grains, and relatively slow diffusion rates for iron in sphalerite (Goble and others, 1979) are considered. 


\section{REFERENCES CITED}

Berg, H. C., Jones, D. L., and Coney, P. J., 1978, Pre-Cenozoic tectonostratigraphic terranes of southeastern Alaska and adjacent areas: U.S. Geological Survey Open-File Report 78-1085, 2 sheets, scale $1: 1,000,000$.

Brew, D. A., 1983, Metamorphism and deformation associated with intrusive suites, Coast Plutonic Metamorphic Complex, southeastern Alaska (abs.): Geological Association of Canada, Program with Abstracts, v. 8, p. A8.

Brew, D. A., and Ford, A. B., 1978, Megalineament in southeastern Alaska marks southwest edge of Coast Range batholithic complex: Canadian Journal of Earth Sciences, v. 15, no. 11 , p. 1763-1772.

Brew, D. A., Grybeck, D., Johnson, B. R., Jachen, R. C., Nutt, C. J., Barnes, D. F., Kimball, A. L., Still, J. C., and Rataj, J. L., 1977, Mineral resources of the Tracy Arm-Fords Terror Wilderness study area and vicinity, Alaska: U.S. Geological Survey Open-File Report 77649,300 p.

Brown, P. E., Essene, E. J., and Kelley, W. C., 1978, Sphalerite geobarometry in the BalmatEdwards District, New York: American Mineralogist, v. 63, no. 3, p. 250-257.

Crawford, M. L., and Hollister, L. S., 1982, Contrast of metamorphic and structural histories across the Work Channel Lineament, Coast Plutonic Complex, British Columbia: Journal of Geophysical Research, v. 87, no. B5, p. 3849-3860.

Goble, R. J., Scott, S. D., and Hancock, R. G. V., 1979, Diffusion rates of $\mathrm{Zn}$ and $\mathrm{Fe}$ in sphalerite (abs.): Geological Association of Canada, Program with Abstracts, v. 4, p. 53.

Hoschek, G., 1969, The stability of staurolite and chloritoid and their significance in metamorphism of pelitic rocks: Contributions to Mineralogy and Petrology, v. 22, no. 3, p. 208-232.

Hutchison, M. N., and Scott, S. D., 1980, Sphalerite geobarometry applied to metamorphosed sulfide ores of the Swedish Caledonides and U.S. Appalachians: Norges Geologiske Unersokelse, v. 360 , p. $59-71$.

Jones, D. L., Silberling, N. J., Berg, H. C., and Plafker, George, 1981, Map showing tectonostratigraphic terranes of Alaska with columnar sec ons, and summary descriptions of ter nes: U.S. Geological Survey Open-File Rep it 81-792, 19 p.

MacKeve , E. M., Jr., and Blake, M. C., Jr., 1964, Geo gy of the Sumdum copper-zinc prospect, sout :astern Alaska: U.S. Geological Survey Bulletin 1108E, $31 \mathrm{p}$.

Scott, S. D., 1976, Application of the sphalerite geobarometer to regionally metamorphosed terranes: American Mineralogist, v. 61 , no. 7 , p. 661-670.
Scott, S. D., and Barnes, H. L., 1971, Sphalerite geothermometry and geobarometry: Economic Geology, v. 66, no. 4, p. 653-669.

Stowell, H. H., 1981, The geology of Sweetheart Ridge and adjacent areas, southeastern Alaska: Columbia, University of South Carolina, Master's thesis, $110 \mathrm{p}$.

Reviewers: D. A. Brew and Cynthia Dusel-Bacon

\section{OFFSHORE ALASKA}

(Figure 72 shows study areas described.)

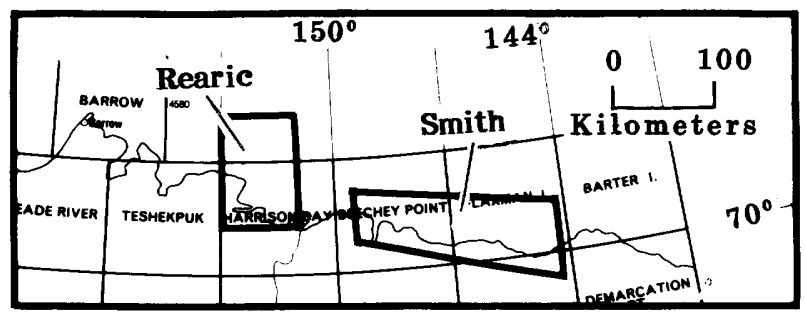

Figure 72.--Areas in offshore Alaska discussed in this circular. Outlines define the areas described by the indicated authors.

\section{CHARACTER AND IMPLICATIONS OF NEW ICE GOUGES IN EASTERN HARRISON BAY, BEAUFORT SEA}

\section{by Douglas M. Rearic}

The gouging action of ice keels extending below the sea-ice canopy on high-latitude continental shelves creates a furrow and ridge microtopography on the sea floor. This gouging is also responsible for the disruption and transport of bottom sediment on the shelf and results in the mixing of shelf sediment to a depth of as much as $5 \mathrm{~m}$ (Reimnitz and Barnes, 1974). In the Alaskan Beaufort Sea, an essentially solid, but mobile, ice canopy exists for about nine months of each year, during which time sub-ice ocean currents are minimal (Matthews, 1981) and sediment transport by hydraulic processes is arrested. Therefore, ice gouging may be the dominant sediment transport process on the shelf during most of the year.

Two tracklines covering different seafloor morphologies in eastern Harrison Bay, $50 \mathrm{~km}$ west of Prudhoe Bay, were surveyed each summer between 1977 and 1982; one covers a relatively smooth, non-shoaled bottom, and the other covers an area containing three successive $2-3 \mathrm{~m}$ high shoals which trend east-west and are subparallel to the isobaths. Repetitive studies using side-scan sonar and fathometer indicate that ice gouging 


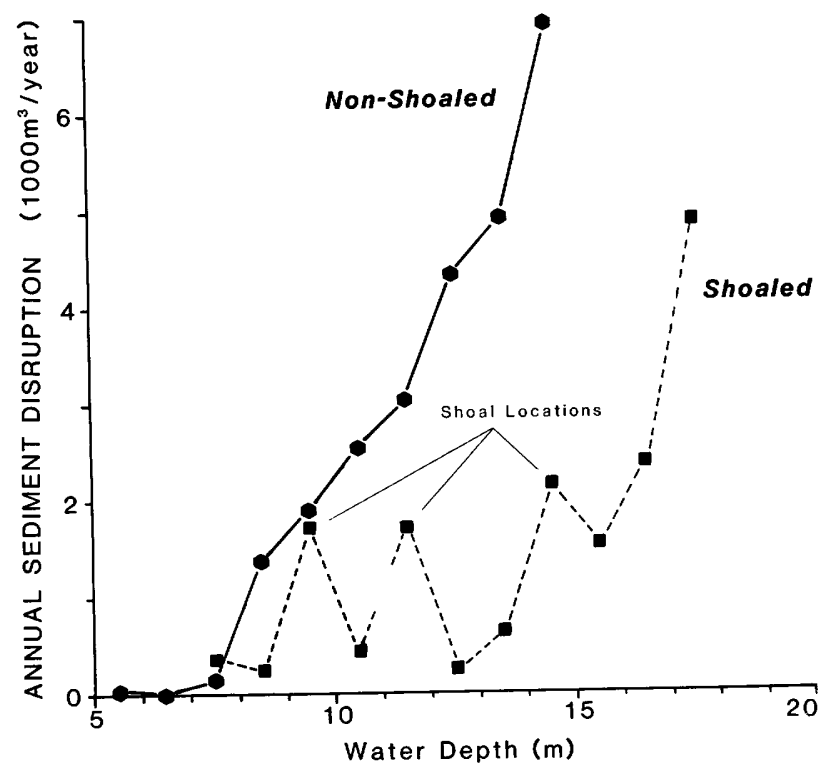

Figure 73.--Estimated volumes of sediment disruption in 1-m water depth intervals for two shelf morphologies in eastern Harrison Bay, Alaska.

occurs over 3.5-3.9 percent of the sea floor each year and that the sea floor is gouged to an average depth of $18 \mathrm{~cm}$. These values represent a slight change in the values reported by Reimnitz and others (1977) and Barnes and others (1978) of 2 percent and $20 \mathrm{~cm}$. The differences are attributed to an increase in record quality from the previous studies, leading to better definition of the smaller gouge events. Measurements made over the 5 years of the study indicated that 75 percent of the gouges formed were less than $20 \mathrm{~cm}$ deep.

One gouge more than $1 \mathrm{~m}$ deep was measured in each area during the study, both occurring in water depths greater than $10 \mathrm{~m}$; gouges this deep account for only 0.1 percent of all gouges formed in these water depths. When the present results are combined with those of the previous studies, the data suggest that in water 10-18 m deep, the recurrence interval for gouges more than $1 \mathrm{~m}$ deep is $6+$ years. By extrapolation, an area $250 \mathrm{~m}$ wide lying between 10 and $16 \mathrm{~m}$ water depth would be gouged 12,500 times in 100 years, and of these gouges, 17 would be more than $1 \mathrm{~m}$ deep.

Yearly sediment disruption volume in a swath $250 \mathrm{~m}$ wide was used to compare shoaled and nonshoaled tracklines. Mean gouge depth, disruption width, and estimated gouge length were used to calculate the mean annual disruption volume for each meter of water depth between 5 and $18 \mathrm{~m}$ (fig. 73). The non-shoaled trackline exhibits a steady increase in disruption volume from 6 to $18 \mathrm{~m}$ depth. Along the shoaled trackline, high sediment volumes are disrupted in segments that contain shoals, while low disruption volumes are found in segments between the shoals. Offshore of the most seaward shoal (below $15 \mathrm{~m}$ depth), there is an increase in disruption volume similar to the increase shown in sediments along the non-shoaled trackline. Shoals, therefore, control the areas of the shelf that will be affected by ice gouging, act as a barrier to the onshore movement of deep ice keels, and reduce sediment disruption by protecting the inshore areas from intense ice gouging. Natural and man-made shoals may offer protection to buried pipelines and wellheads in the shallow shelf areas of the Beaufort Sea.

\section{REFERENCES CITED}

Barnes, P. W., McDowell, D. E., and Reimnitz, Erk, 1978, Ice gouging characteristics: their changing patterns from 1975- 1977, Beaufort Sea, Alaska: U.S. Geological Survey Open-File Report 78- 730, 42 p.

Matthews, J. B., 1981, Observations of under-ice circulation in a shallow lagoon in the Alaskan Beaufort Sea: Ocean Management, v. 6, p. 223-234.

Reimnitz, Erk, and Barnes, P. W., 1974, Sea ice as a geologic agent on the Beaufort Sea shelf of Alaska, in Reed, J. C., and Sater, J. E., eds., The Coast and Shelf of the Beaufort Sea: Arlington, Virginia, The Arctic Institute of North America, p. 301-351.

Reimnitz, Erk, Barnes, P. W., Toimel, L. J., and Melchior, J., 1977, Ice gouge recurrence and rates of sediment reworking, Beaufort Sea, Alaska: Geology, v. 5, p. 405-408.

Reviewers: P. W. Barnes and M. S. Marlow

\section{LATE QUATERNARY GEOLOGY OF THE BEAUFORT SEA INNER SHELF NEAR PRUDHOE BAY}

\section{by Peggy Smith}

A detailed study of seven sediment cores from the innermost shelf east of Prudhoe Bay (fig. 74) has provided a record of three pre-Holocene Quaternary marine transgressions, as well as an episode of deltaic sedimentation. Holocene sediments are found only in the cores from the two boreholes in a protected lagoon. High resolution seismic surveys in the area document two prominent reflectors resembling erosional surfaces (Stephen Wolf, U.S. Geological Survey, oral commun., Oct. 1983). The core studies confirm the erosional nature of the surfaces and provide some indication of the ages of the features. Figures 75 and 76 are correlation diagrams using data from the boreholes and showing unit characteristics and positions of prominent seismic reflectors.

The oldest of the transgressive/regressive deposits described in this study, the Leffingwell 
Lagoon unit, ranges in thickness from 5.5 to 18.0 $\mathrm{m}$. Its base correlates well with a strong, laterally persistent, seismic reflector (no. 3). In hole HLA 14 the unit consists of nearshore deposits, whereas in HLA 15 it is alluvial sand. In holes HLA 16-20, the unit consists of marine silt and clayey silt overlying gravelly beach and nearshore deposits. Microfossil assemblages in the lower half of this unit indicate mid-neritic water depths $(20-40 \mathrm{~m})$ and an influx of warmer, more saline Atlantic water; those in the upper half of the unit reflect a shallowing trend and are similar to modern fauna of the Alaskan Beaufort Sea (K. A. McDougall and E. M. Brouwers, U.S. Geological Survey, written commun., April,1981).

A second transgressive/regressive cycle is represented by the Maguire Islands unit, which ranges in thickness from 6 to $15 \mathrm{~m}$. The unit is composed of nearshore to deltaic sand and clayey silt in HLA 14, and in HLA 15 it consists of alluvial clayey to sandy gravel. In HLA 20, the unit consists of shallow to mid-shelf silt to clayey silt. In holes HLA 16-19, a basal transgressive layer of sandy gravel or pebbly, shelly mud unconformably overlies silty clay of the Leffingwell Lagoon unit. Above this layer, the unit undergoes a progressive change from shallow marine silt to deltaic silty sand. Microfossil assemblages throughout the unit are characterized by small populations, low diversity, and species suggestive of frigid to subfrigid, low salinity, shallow marine conditions. Samples taken from the upper part of the unit for study of microfossils are either barren or the faunas are very depauperate; the samples represent a primarily nonmarine deltaic environment.

Reflector no. 4 correlates well with the erosional unconformity between the Leffingwell Lagoon and the Maguire Islands units. The seismic records document prodelta and delta foreset sequences corresponding to shallow marine and deltaic sediments from cores in the Maguire Islands unit. Seismic profiles also show numerous cut-and-fill structures in the upper part of the unit, suggesting subaerial exposure and minor lateral shifting of distributary channels.

In all cores except HLA 14 and 15, the Maguire Islands unit is overlain by another shallow marine transgressive sequence, the Cross Island unit, which ranges in thickness from 3.5 to $7 \mathrm{~m}$. This unit is primarily clayey silt to silty sand, and it contains microfaunal assemblages indicative of cool

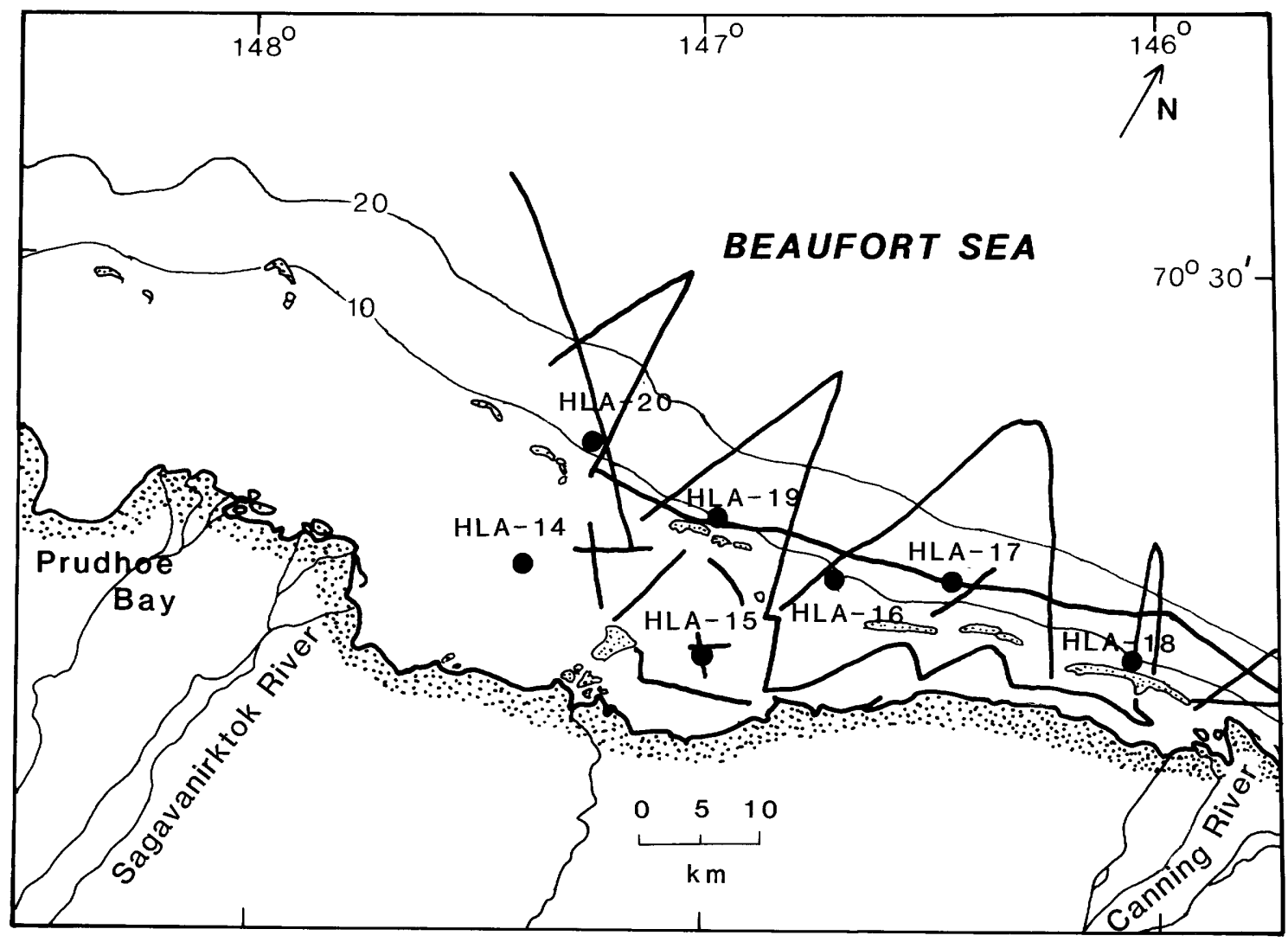

Figure 74.--Map showing locations of boreholes (heavy dots) and high resolution seismic reflection tracklines (heavy lines). Depth contours are in meters. 


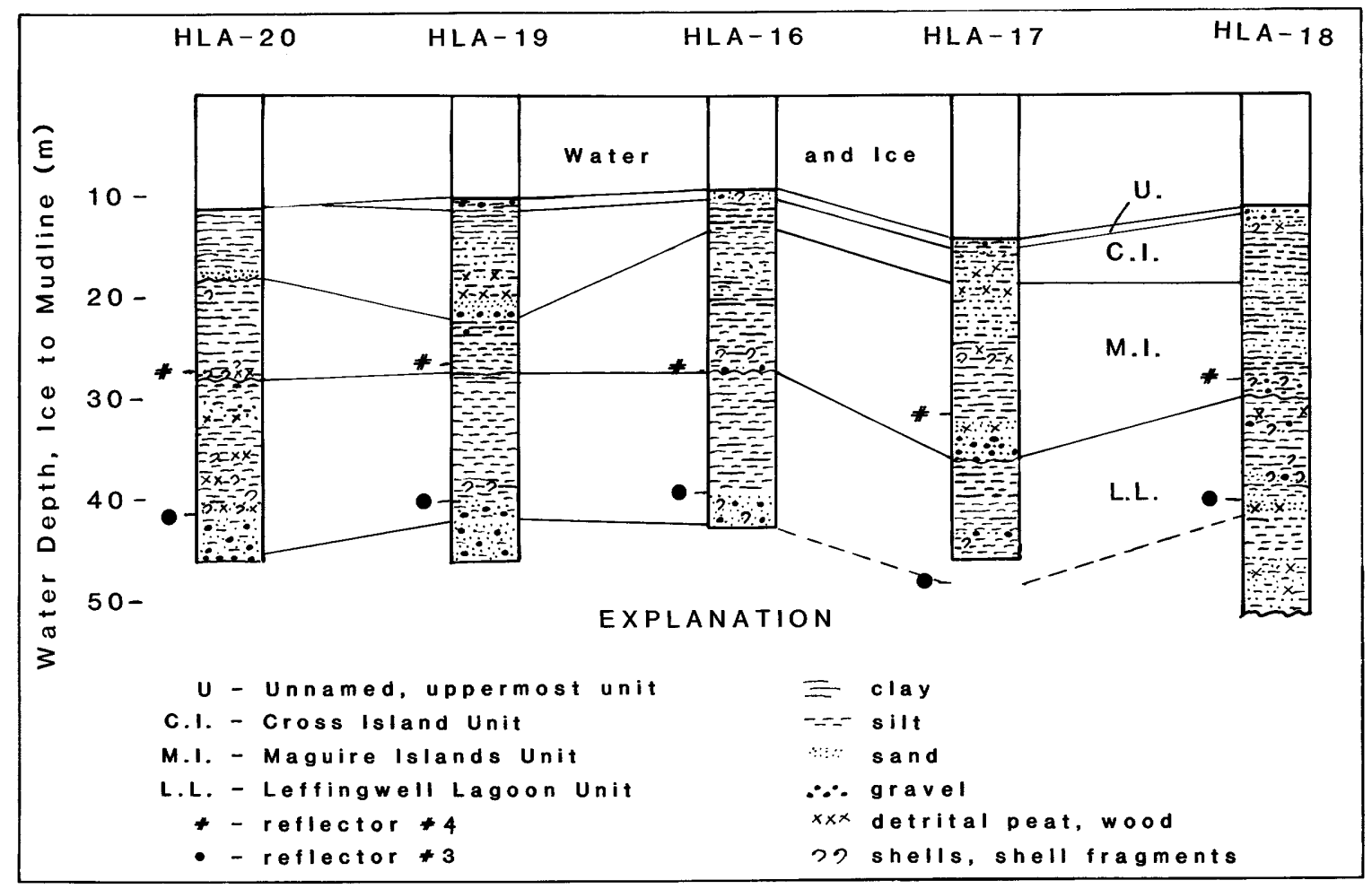

Figure 75.--Correlation diagrams, from west to east, of boreholes HLA 16-20, showing generalized sedimentary character, position of prominent reflectors, and unit designations.

temperature, low to variable salinity, and shallow marine conditions.

In cores HLA 16-19, the uppermost meter of sediment is composed of sandy silt with pebbles, shell fragments, and reworked microfossils; these sediments represent erosion of the underlying unit. The uppermost 5 to $6 \mathrm{~m}$ of sediments in holes HLA 14 and 15 consist of black organic-rich silt and clayey silt with shallow marine/estuarine faunas; these are interpreted as lagoonal deposits.

Microfaunal assemblages, degree of consolidation of the sediments, and reference to seismic stratigraphy on the shelf provide means of correlating the borehole record with marine transgressions documented elsewhere in Alaska. Reflector no. 4, defining the contact between the Leffingwell Lagoon unit and the overlying Maguire Islands unit, coincides with a prominent reflector traceable on Uniboom records from the mid- to outer shelf. D. A. Dinter (U.S. Geological Survey, written commun., Oct. 1983) believes this reflector records the subaerial exposure of the present mid-shelf region during the Illinoian glaciation (oxygen isotope stage 6). The Leffingwell Lagoon unit predates the disconformity, and its microfauna limits its age to middle Pleistocene or younger; thus it correlates with deposits of the Kotzebuan transgression of Hopkins (1967).

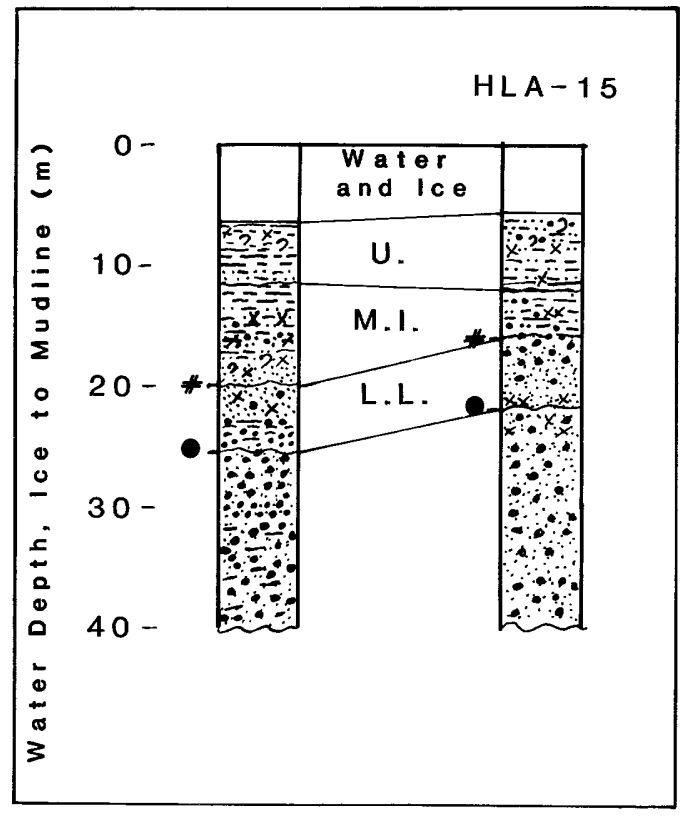

Figure 76.--Correlation diagrams, from west to east, of boreholes HLA 14 and 15. Symbols are the same as in figure 75 . 
The Maguire Islands unit represents deposition during oxygen isotope stage 5 . The lower marine part of the unit represents Sangamon deposition, with shallow subaqueous to subaerial deltaic sedimentation beginning as sea level dropped slightly during the earliest Wisconsin. Deep channels were cut into the upper part of the unit, suggesting that sea level dropped considerably after its deposition; thus the unit must be older than the late Wisconsin sea level low-stand. The Maguire Islands unit can be traced westward across the inner shelf toward Reindeer Island, where it is correlated with a marine unit assigned to the Sangamon interglacial (Hartz and Hopkins, 1981). Recent studies indicate that two transgressions are represented in this marine unit: one of Sangamon age, and the other corresponding to the Flaxman Member of the Gubik Formation of probable early Wisconsin age.

The age of the Cross Island unit is more uncertain. The overconsolidated nature of the sediments suggests that it is pre-Holocene, but whether it represents a middle Wisconsin marine transgres- sion or a fluctuation of sea level during the Flaxman transgression cannot be determined at this time. Conversely, the unconsolidated nature of the unnamed lagoonal deposits in holes HLA 14 and 15 suggests that they represent Holocene deposition.

\section{REFERENCES CITED}

Hartz, R. W., and Hopkins, D. M., 1981, A review of offshore permafrost studies, Beaufort Sea, Alaska, 1976 to 1980, in Environmental assessment of the Alaskan continental shelf, v. 4, Hazards; Principal investigators annual reports for the year ending March 1980: Rockville, Md., U.S. National Oceanic and Atmospheric Administration, p. 167-177.

Hopkins, D. M., 1967, Quaternary marine transgressions in Alaska, in Hopkins, D. M., ed., The Bering Land Bridge: Stanford University Press, p. 47-90.

Reviewers: D. M. Hopkins and D. A. Dinter

We thank Robert F. Gi lmore and Linda L. Harr is, Anchorage, who provided technical expertise

in the preparation of illustrations for this circular. 


\section{LISTING OF REFERENCES BY SUBJECT MATTER}

\section{ECONOMIC GEOLOGY}

Brew, David A., Kar 1, Susan M., and Tobey, Eugene F., Re-interpretation of age of Kuiu-Etolin belt volcanic rocks, Kupreanof Is land, southeastern Alaska..............866

Nokleberg, Warren J., and Lange, Ian M., Vol canogenic massive sulfide occurrences, Jarvis Creek Glacier terrane, western Mount Hayes Quadrangle, eastern Alaska Range.........77

Pick thorn, Wi 11 iam J., Goldfarb, Richard J., O'Leary, Richrd M., Sutley, Stephen J., and Weaver, Sarah, Kayak Is land--Ana lys is of a geochemical anomaly...........82

York, James E., Wi lson, Freder ic H., and Gamble, Bruce M., Digital image processing techniques for detecting surface alteration-An application on the Alaska Peninsula...........57

\section{GENERAL GEOLOGY}

Brew, David A., Kar l, Susan M., and Tobey, Eugene F., Re-interpretation of age of Kuiu-Etolin belt vol canic rocks, Kupreanof Is land, southeastern Alaska..............86

Chapman, Robert M., Trexler, James H., Jr., Churkin, Mi chae 1, Jr., and Weber, Florence R., New concepts of the Mesozoic flysch belt in east-

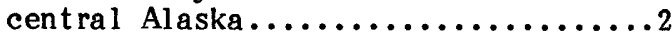

Dillon, John T., Patton, Wi 11 i am W. , Jr., Mukasa, Samuel B., Til ton, George R., Blum, Joe 1, and Moll, Elizabeth J., New radiometric evidence for the age and thermal $h$ istory of the metamorphic rocks of the Ruby and Nixon Fork terranes, west-central Alaska........13

Dover, James H., and Mi yaoka, Ronny T., Major rock packages of the Ray Mountains, Tanana and Bettles

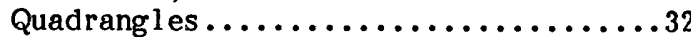

Dumoulin, Julie A., and $\mathrm{Till}, \mathrm{Al}$ ison B., Sea-cliff exposures of metamorphosed carbonate and sch ist, nor thern Seward Peninsula.................. 18

Foster, Helen L., and Cushing, Grant W., Tertiary(?) folding in the Tanacross

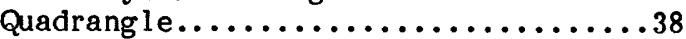

Grybeck, Dona ld J., Cathra ll, John B., LeCompte, James R., and Cady, John W., Buried felsic plutons in Upper Devonian redbeds, central

Brooks Range................... 8

Mi ller, Marti L., and Bundtzen, Thomas

K., Metamorphic rocks in the western Idi tarod Quadrangle, westcentral Alaska.................24

\section{GEOCHEMI STRY}

Antwe iler, John C., Tripp, Ri chard B., Cathra 11, John B., and Mosier, Elwin L., Studies of gold in the Chandalar and Koyukuk Districts, Wi seman and Bett les Quadrang les......28

Erdman, James A., and Motooka, Jerry M., Biogeochemical response at the Greens Creek massive sulfide deposit, Admi ralty Is land...

Fi lipek, Lor raine H., Botinelly, Theodore, and Ficklin, W. H., Relations between the tidal-flat environment and upstream minera 1ization, Petersburg Quadrangle......92

Jones, Gail M., Menzie, W. David, and Foster, Helen L., Statistical discrimination between potential tinand uranium-bearing areas in eastcentral Alaska on the basis of stream-sediment trace-element geochemi stry......................40

LeHuray, Anne P., Church Stanley E., and Nokleberg, Warren J., Lead isotopes in sulfide deposits from the Jarvis Creek Glacier and Wrange llia terranes, Mount Hayes Quadrangle, eastern Alaska Range......72

LeHuray, Anne P., Stowe 11, Harold S., and Church, Stanley E., Lead isotopes from volcangenic massive sulfide deposits from the Alexander terrane, southeastern Alaska......95

Watterson, John R., Nishi, James M., and Botinelly, Theodore, Evidence that gold crystals can nucleate on bacterial spores................... 1

Yeend, Warren, Trace elements of placer gold........................4

\section{GEOCHRONOLOGY}

Ale inikoff, John N., and Nokleberg, Warren J., Age of intrusion and metamorphism of a granodior ite in the Lake George terrane, nor theastern Mt. Hayes Quadrangle...................... 6 


\section{GEOPHYSICS}

Barnes, David F., and Csejtey, Bela, Jr., Geophysical data emphasize importance of the Talkeetna fault system relative to the Denali system.......................65

Campbe 11, David L., and Nokleberg, Warren J., Magnetic profile across the Denali fault, Mount Hayes Quadrangle, Eastern Alaska Range........68

\section{MAR INE GEOLOGY}

Filipek, Lor ra ine H., Botinelly, Theodore, and Ficklin, W. H., Relations between the tidal-flat environment and upstream mineralization, Petersburg Quadrangle..............92

Rearic, Douglas M., Character and implications of new ice gouges in eastern Harr ison Bay, Beaufort Sea ............................. 99

\section{PALEONTOLOGY / PALEOBOTANY}

Miller, John W., and Det terman, Robert

L., The Buchia zones in Upper

Jurassic rocks on the Alaska

Pen insula......................51

Reed, Kather ine M., Blome, Char les D.,

Gi lbert, Wyatt W., and Solie,

Diana L., Jurassic radiolaria from

the Lime Hills Quadrang le...........53

\section{PETROLOGY, IGNEOUS}

Loney, Robert A., and Himmelberg, Glen R. Per idotite-layered gabbro complex of the southeastern Yukon-Koyukuk ophiolite belt..................46

\section{PETROLOGY, METAMORPHIC}

Himme lberg, Gl en R., Ford, Ar thur B., Brew, David A., and Van Horn, Stephen, Chemical zonation of garnet in pelitic rocks of the Coast pluton ic-metamorphic complex near Juneau......................91

Stowe 11, Harold, Sphaler i te geobarometry in the Coast Range megali neament zone near Holkham Bay, southeastern $\mathrm{Al}$ aska.

\section{PETROLOGY, SEDIMENTARY}

Lul1, John S., and Plafker, George, Petrology of sandstone from the Yaku tat Group, Malaspina district, southern Alaska............73

\section{QUATERNARY GEOLOGY}

Brew, David A., Kar 1, Susan M., and Tobey, Eugene F., Re-interpretation of age of Kuiu-Etolin belt volcan ic rocks, Kupreanof Island, sou theastern Alaska...............86

Kau fman, Darrell S., Windy Creek and Crater Creek faults, Seward Peninsula..................22

Smith, Peggy, La te Qua ternary geology of the Beaufort Sea inner shelf near Prudhoe Bay.................100

Yount, M. El izabeth, Wi lson, Freder ic H., and Miller, John W., Newly discovered Holocene volcanic vents, Port Moller and Stepovak Bay Quadrangles......................60

\section{SEI SMOLOGY}

Page, Robert A., Stephens, Christopher D., Fogleman, Kent A., and Maley, Richard P., The Columbia Bay earthquakes of 1983 , southern Alaska........................80

Stephens, Chr is topher D., Fogleman, Kent A., Page, Robert A. and Lahr, John C., Se ismic ity in southern Alaska, October 1982Sep tember $1983 \ldots \ldots \ldots \ldots \ldots \ldots \ldots . . . . .83$

\section{STRATIGRAPHY}

Detterman, Robert L., and Miller, John W., Kaguyak Formation--An Upper Cretaceous flysch deposit...........49

Nilsen, Tor H., Brosge, William P., and Dutro, J. Thomas, Jr., New reference section of the Noatak Sandstone, Nimi uk tuk River, Misheguk Moun ta in Quadrangle, central Brooks Range. 


\section{STRUCTURAL GEOLOGY/TECTONICS}

Dover, James H., and Miyaoka, Ronny T., Metamorphic rocks of the Ray Moun tains--Prel iminary structural analysis and regional tectonic implications......................

Foster, He len L., and Cushing, Grant W., Tertiary(?) folding in the Tanacross

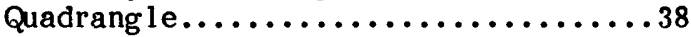

Page, Robert, Stephens, Chr is topher D., Fog leman, Kent A., and Ma ley, Ri chard P., The Columbia Bay earthquakes of 1983 , southern Alaska.........................80

Stephens, Chris topher D., Fog leman, Kent A., Page, Robert A., and Lahr, John C., Seismicity in southern Alaska, Oc tober 1982Sep tember 1983...................83

Wi lson, Freder ic H., Case, James E., and Detterman, Robert L., Pre- liminary description of a Miocene zone of structural complexity in the Port Moller and Stepovak Bay Quadrang les......................55

\section{VOLCANOLOGY}

Brew, Dav id A., Kar 1, Susan M., and Tobey, Eugene F., Re-interpretation of age of Kuiu-Etolin belt volcan ic rocks, Kupreanof Is land, sou theastern Al aska...............86

Yount, M. El izabeth, Miller, Thomas P., Emanue 1, Richard P., and Wi lson, Frederic H., Eruption in the icefilled caldera of Mount Veniaminof....59

Yount, M. Elizabeth, Wilson, Frederic H., and Miller, John W., Newly discovered Holocene volcanic vents, Port Moller and Stepovak Bay Quadrangles .60 
Ale in ikoff, John N.,....... 62

An twe il er, John C.......... 28

Barnes, David F............ 65

Blome, Char les D........... 53

Bl um, Joel.............. 13

Bot inelly, Theodore........ 1,92

Brew, David A.......... 86,91

Brosge, Wi lliam P.......... 10

Bundtzen, Thomas K.......... 24

Campbe 11, David L..........68 68

Cady, John W............. 8

Case, James E............. 55

Cathrall, John B..........8, 28

Chapman, Robert M..........29

Church, Stan ley E........ 72,95

Churk in, Mi chae 1, Jr.......29

Csejtey, Bela, Jr..........65

Oushing, Grant W........... 38

Detterman, Robert L.... 49,51,55

Dillon, John T............ 13

Dover, James H.......... 32,36

Dumou lin, Julie A.......... 18

Dutro, J. Thomas, Jr......... 10

Enanue 1, Ri chard P......... 59

Erdman, James A.......... 88

Ficklin, Wal ter H...........99 92

Fil ipek, Lorra ine H......... 92

Fogleman, Kent A........8 80,83

Ford, Arthur B............ 91

Foster, Helen L.......... 38, 40

Gamble, Bruce M........... 56

Gi lbert, Wyatt G........... 53

Goldfarb, Richard J......... 82

Grybeck, Donald J.......... 8

Himme lberg, Gl en R...... 46,91

Jones, Ga il M............ 40

Kar 1, Susan M............ 86

Kau fman, Darre 11 S.......... 22

Lahr, John C............. 83

Lange, I an M............. 77

LeCompte, James R........... 8
LeHuray, Anne P......... 72,95

Loney, Robert A...........46

Lull, John S............. 73

Maley, Richard P.......... 80

Menzie, W. David........... 40

Mi 11 er, John W........44, 51,60

Mi 1 ler, Marti L............24

Mi 11 er, Thomas P........... 59

Mi yaoka, Ronny T......... 32,36

Mo1l, El izabeth J........... 13

Mosier, Elwin L............ 28

Motooka, Jerry M.......... 88

Mukasa, Samuel B........... 13

Nilsen, Tor H............ 10

Nish i, James M............. 1

Nokl eberg, Warren J.. 62,68,72,77

O'Leary, Richard M......... 82

Page, Robert A......... 80,83

Patton, Wi 11 i am W., Jr....... 13

Pick thorn, William J........ 82

Plafker, George,........... 73

Rearic, Douglas M.......... 99

Reed, Kather ine M.......... 53

Smi th, Peggy............. 100

Solie, Diana N............ 53

Stephens, Chr is topher D...8 80,83

Stowe 11, Harold S........ 95,96

Sutley, Stephen J.......... 82

Till, Alison B............ 18

Til ton, George R........... 13

Tobey, Eugene F.......... 86

Trexler, James H., Jr....... 29

Tripp, Richard B.......... 28

Van Horn, Stephen.......... 91

Watterson, John R........... 1

Weaver, Sarah............. 82

Weber, Florence R........... 29

Wil son, Freder ic H... $55,56,59,60$

Yeend, Warren..............4 4

York, James E............. 56

Yount, M. El izabeth...... 59,60 




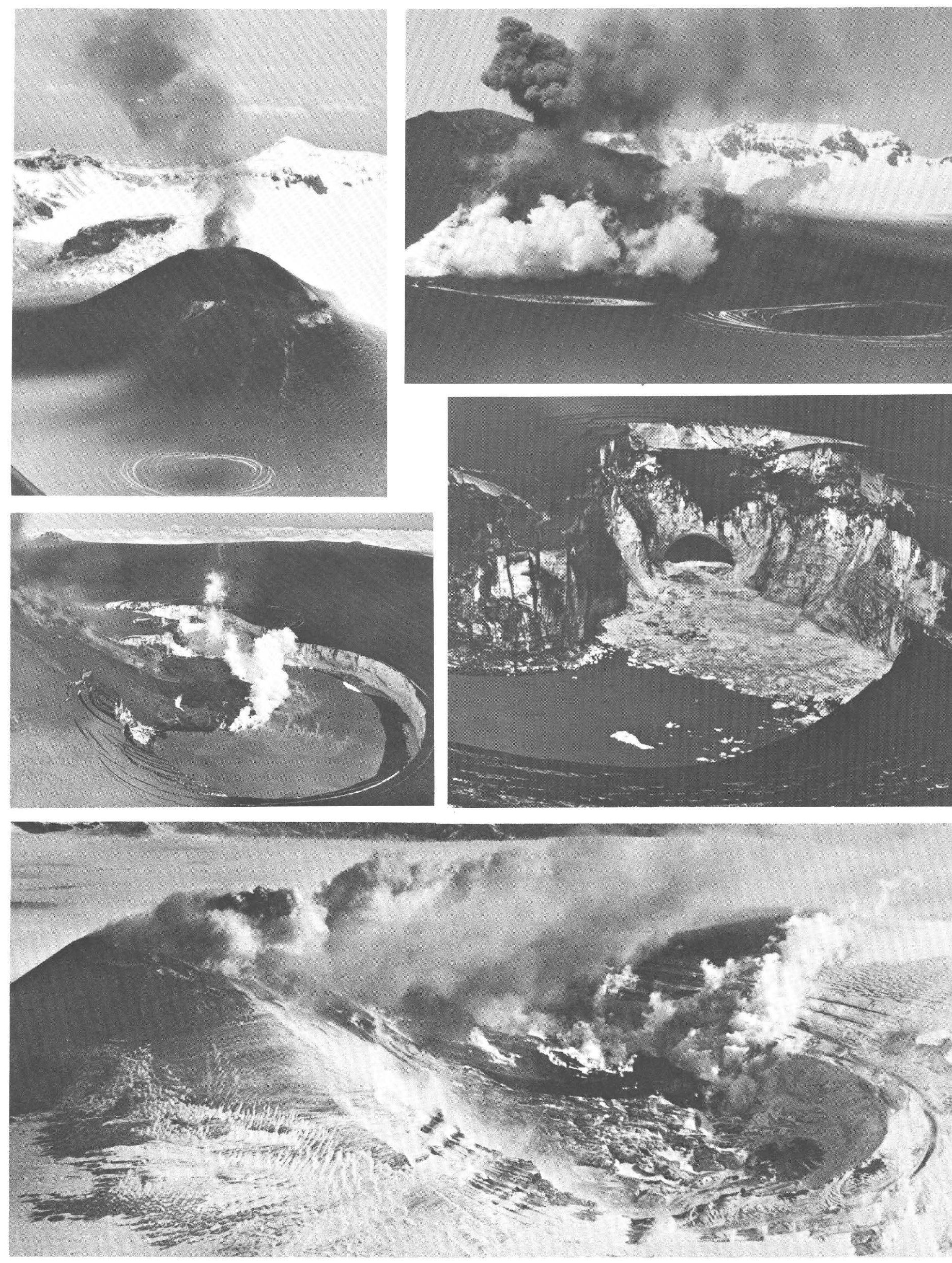